\title{
Civis Europaeus sum?
}

Citation for published version (APA):

Marrero Gonzalez, G. (2017). Civis Europaeus sum? Consequences with regard to nationality law and EU citizenship status of the independence of a devolved part of an EU member state. [Doctoral Thesis, Maastricht University]. Wolf Legal Publishers (WLP). https://doi.org/10.26481/dis.20170629gmg

\section{Document status and date:}

Published: 01/01/2017

DOI:

10.26481/dis.20170629gmg

Document Version:

Publisher's PDF, also known as Version of record

\section{Please check the document version of this publication:}

- A submitted manuscript is the version of the article upon submission and before peer-review. There can be important differences between the submitted version and the official published version of record.

People interested in the research are advised to contact the author for the final version of the publication, or visit the DOI to the publisher's website.

- The final author version and the galley proof are versions of the publication after peer review.

- The final published version features the final layout of the paper including the volume, issue and page numbers.

Link to publication

\footnotetext{
General rights rights.

- You may freely distribute the URL identifying the publication in the public portal. please follow below link for the End User Agreement:

www.umlib.nl/taverne-license

Take down policy

If you believe that this document breaches copyright please contact us at:

repository@maastrichtuniversity.nl

providing details and we will investigate your claim.
}

Copyright and moral rights for the publications made accessible in the public portal are retained by the authors and/or other copyright owners and it is a condition of accessing publications that users recognise and abide by the legal requirements associated with these

- Users may download and print one copy of any publication from the public portal for the purpose of private study or research.

- You may not further distribute the material or use it for any profit-making activity or commercial gain

If the publication is distributed under the terms of Article $25 \mathrm{fa}$ of the Dutch Copyright Act, indicated by the "Taverne" license above, 


\section{Civis europaeus sum?}

Consequences with regard to Nationality Law and EU Citizenship status of the Independence of a Devolved Part of an EU Member State 


\title{
Civis europaeus sum?
}

\section{Consequences with regard to Nationality Law and EU Citizenship status of the Independence of a Devolved Part of an EU Member State}

\author{
Guayasén Marrero González
}

ISBN: 9789462403413

Published by:

ฟolf Legal Publishers (WLP)

PO Box 313

5060 AH Oisterwijk

The Netherlands

E-Mail: info@wolfpublishers.nl

www.wolfpublishers.com

All rights reserved. No part of this publication may be reproduced, stored in a retrieval system, or transmitted in any form or by any means, electronic, mechanical, photocopying, recording or otherwise, without prior written permission of the publisher. Whilst the authors, editors and publisher have tried to ensure the accuracy of this publication, the publisher, authors and editors cannot accept responsibility for any errors, omissions, misstatements, or mistakes and accept no responsibility for the use of the information presented in this work.

(C) Author / WLP 2017 


\title{
Civis europaeus sum?
}

\section{Consequences with regard to Nationality Law and EU Citizenship status of the Independence of a Devolved Part of an EU Member State}

\author{
DISSERTATION
}

To obtain the degree of Doctor at Maastricht University, on the authority of Rector Magnificus Prof. dr. Rianne M. Letschert in accordance with the decision of the Board of Deans

to be defended in public on

Thursday 29th June 2017, at 10:00 hours

by

Guayasén Marrero González 


\section{Supervisor:}

Prof. dr. G.R. de Groot

\section{Co-Supervisor:}

Dr. Sergio Carrera Núñez (Brussels)

\section{Assessment Committee:}

Prof. dr. B. De Witte (Chair)

Prof. dr. J. Shaw (University of Edinburgh)

Prof. dr. M. P. Vink

Prof. dr. P. Wautelet (Université de Liège) 


\section{Acknowledgements}

A couple of years ago, I arrived in Maastricht with the aim of getting my LL.M. degree and coming back to the Canary Islands. However, as unpredictable as life is, I also got the chance to pursue my $\mathrm{PhD}$ at this University. On this intense journey, I have not walked alone for a single minute.

I would like to thank Prof. René de Groot, for giving me the opportunity to develop my professional career. This book is a result of his belief in me. Thank you so much. I would also like to thank Prof. Hildegard Schneider whom, together with Prof. de Groot, opened the door of their house and family. There have been numerous dinners in Amby from which my research has benefited from valuable comments and remarks. Thanks; I will never forget that I also have a family in Maastricht. I am really grateful to Dr. Sergio Carrera Núñez. I could not have thought of a better co-supervisor, ¡muchas gracias! And Sophia de Groot, thanks for the great cover design.

I would also like to thank the members of my assessment committee, Bruno de Witte, Jo Shaw, Maarten Vink and Patrick Wautelet, for taking the time and care to read the thesis and for providing me with such insightful feedback. My thanks also go to Maastricht University and the Faculty of Law, my colleagues, the Graduate School of Law, PhD researchers and staff members. You are all simply amazing.

This research was also supported by Fundació la Caixa and its 'programa Europa'. Thanks for providing the financial support and opening the doors to the big family of 'becarios de la Caixa'.

There is a core group of people to whom I am really grateful: my beloved friends from PPW and the Inkom group; my bro, Alex, always there; mi amiga, Marta, siempre ahí; my Master's colleagues with whom I discovered deze mooie stad, Maastricht; my flatmates; the Musketeers; the Sonorama team; my friends and professors at Universidad de La Laguna; the colleagues and friends with whom I first worked as a lawyer; my paranyphms; the people in the towns where I grew up, San Cristóbal de La Laguna and La Aldea de San Nicolás de Tolentino; the Caberg crew; the new friends that I have met throughout my Dutch adventure and to all of you that I have shared part of my journey with. You have all had an impact on me.

Finalmente, a mi familia, mis abuelas y abuelos, mis tíos y tías, primos y primas dentro y fuera de ese paraíso que son las Islas Canarias, muchas 
gracias. Gracias también a esa segunda familia, esa con la que no compartes lazos de sangre, pero que acaban convirtiéndose en parte esencial de tu vida; ellos son todos unos "cremas". Y especialmente este agradecimiento es a mis padres, Agustín y Eva, y a mi hermana, Paula. A mis padres, porque a ellos debo todo lo que soy. Fueron mis primeros maestros, quienes me enseñaron el valor del trabajo bien hecho y la importancia de poder dormir cada noche con la conciencia tranquila. Ellos guiaron mis primeros pasos y, sin lugar a duda, su ejemplo seguirá guiando mis pasos futuros. A mi hermana, porque no puedo imaginar una mejor compañera para el camino. 


\section{Table of contents}

Acknowledgements I

Table of contents

List of abbreviations of international treaties, protocols and

recommendations $\quad$ VII

Other abbreviations

Glossary of Latin terms $\quad$ X

Glossary of legal terminology related to State succession XII

Chapter 1: Introduction $\quad 1$

1. State Succession "within" the European Union 1

2. Research Questions 8

3. Scope 10

3.1 Nationality Law 11

$\begin{array}{ll}3.2 \text { Territorial Scope } & 14\end{array}$

$\begin{array}{ll}3.3 \text { Personal Scope } & 18\end{array}$

4. Methodology and Structure 19

5. Concluding Remarks 29

Chapter 2: State Succession and Nationality in International Law 31

1. State Succession: General Overview 31

1.1 Brief Notes on Statehood $\quad 31$

$\begin{array}{ll}1.2 \text { State Succession. } & 35\end{array}$

2. Self-Determination 39

3. Membership of International Organisations 46

4. Automatic State Succession to Human Right Treaties 54

5. State Succession and its Effects on Nationality of Natural Persons: The attribution of Nationality upon Independence $\quad 58$

$\begin{array}{ll}5.1 \mathrm{UN} \text { - International Law Commission } & 58\end{array}$

$\begin{array}{ll}5.2 \text { Council of Europe } & 63\end{array}$

6. The Decolonisation Process 66

$\begin{array}{ll}6.1 \text { Spain } & 66\end{array}$

$\begin{array}{ll}\text { 6.1.1 Ifni } & 67\end{array}$

$\begin{array}{ll}\text { 6.1.2 Equatorial Guinea } & 70\end{array}$

$\begin{array}{ll}\text { 6.1.3 Western Sahara } & 71\end{array}$

$\begin{array}{ll}6.2 \text { Belgium } & 79\end{array}$

6.3 The United Kingdom $\quad 82$

6.4 Identified Patterns $\quad 92$

7. Concluding Remarks 94 
Chapter 3. State Succession in the EU:

Catalonia, Flanders and Scotland

1. Introduction 101

2. Catalonia 101

3. Flanders 122

4. Scotland 126

5. Referenda, Consultation, Electoral rights and First Determination of

5.1.1 Eligibility to Vote in the Independence Query 137

5.1.2 Eligibility for Catalan Nationality ab initio in a Potential New Catalan State 139

$\begin{array}{ll}\text { 5.2 Flanders } & 147\end{array}$

5.2.1 Introductory Remarks on an Independence Query in Flanders 147

5.2.2 Eligibility for Flemish Nationality ab initio in a Potential New Flemish State $\quad 148$

5.3 Scotland

5.3.1 Eligibility to Vote in the Independence Query

5.3.2 Eligibility for Scottish Nationality ab initio in a Potential New Scottish State

6. Concluding Remarks

Chapter 4: State Succession in the EU. EU Citizenship and Nationality Law $\quad 157$

$\begin{array}{ll}\text { 1. Introduction } & 157\end{array}$

2. EU citizenship vs. Member State Nationality 158

3. CJEU case law 164

3.1 Mario Vicente Micheletti and Others v Delegación del Gobierno en Cantabria

3.2 The Queen and Secretary of State for the Home Department v Manjit Kaur

3.3 Kunqian Catherine Zhu, Man Lavette Chen v Secretary of State for the Home Department

3.4 M. G. Eman, O.B. Sevinger v College van burgemeester en wethouders van Den Haag

3.5 Janko Rottmann v. Freistaat Bayern 173

4. Maltese Citizenship-for-Sale Programme 176

$\begin{array}{ll}\text { 5. Concluding Remarks } & 179\end{array}$

Chapter 5. State Succession and the Right to Reside Permanently $\quad 181$

1. The Kurić doctrine 181

$\begin{array}{ll}1.1 \text { The Facts of the Case } & 181\end{array}$

1.2 Proceedings before the Third Section 186

1.3 Proceedings before the Grand Chamber 187

2. Applying the Kurić Doctrine in a State Succession Scenario "within" the EU 189

3. Right to Reside as a Non-EU Member State National in an EU

Member State upon Independence 194

3.1 The Specific Case of Former British nationals residing in the UK 202 
4. Right to Reside in the Newly Independent States

4.1 Nationals of the Predecessor State and EU citizens residing in the Newly Independent State

4.2 TCNs residing in the Newly Independent State

5. Remarks on the Position of Minors

6. Concluding Remarks

Bibliography

Treaties, legislation, reports and other documents

United Nations documents

Council of Europe documents

Bilateral treaties

Other documents

EU law

Other EU related documents

Domestic law

Canada

Congo

France

Malta

Slovenia

Spain

United Kingdom

\section{Case law}

\section{Summary}

Resumen

\section{Samenvatting}

\section{Valorisation Addendum}

1. Societal Relevance of this Thesis $\quad 287$

2. Target Groups for the Research Results 288

3. Innovative Character of this Thesis 288

4. Concrete Products, Services, Processes and Activities into which the Research Results will be translated and shaped

5. Implementing the Research Results 



\section{List of abbreviations of international treaties, protocols and recommendations}

CEDAW 1979 Convention on the Elimination of All Forms of Discrimination against Women

CRMN 1963 Convention on Reduction of Cases of Multiple Nationality

CRMN (1st) 1977 Additional Protocol to the CRMN

CRMN (2nd) 1993 Second Protocol amending the CRMN

CRS 1961 Convention on the Reduction of Statelessness

1999 Draft Articles by the International Law Commission on Nationality of Natural Persons in Relation to the Succession of States

ECN 1997 European Convention on Nationality

ECSS 2006 Council of Europe Convention on the Avoidance of Statelessness in Relation to State Succession

HCNL 1930 Hague Convention on Certain Questions relating to the Conflict of Nationality Laws

ILEC Involuntary Loss of European Citizenship

Rec 2009/13 Recommendation CM/Rec (2009)13 of the Committee of Ministers to member states of the Council of Europe on the nationality of children

1948 Universal Declaration of Human Rights 


\section{other abbreviations}

$\begin{array}{ll}\text { BGBl. } & \text { Bundesgesetzblatt (German official gazette) } \\ \text { BOE } & \text { Boletín Oficial del Estado (Spanish official gazette) } \\ \text { Cc esp. } & \text { Código civil español (Civil code of Spain) } \\ \text { CETS } & \text { Council of Europe Treaty Series } \\ \text { CiU } & \text { Convergència i Unió } \\ \text { CJEU } & \text { Court of Justice of the European Union } \\ \text { CoE } & \text { Council of Europe } \\ \text { DGRN } & \text { Dirección General de Registros y Notariado } \\ \text { ECHR } & \text { European Convention on Human Rights } \\ \text { ECtHR } & \text { European Court of Human Rights } \\ \text { ECR } & \text { European Court Reports } \\ \text { Ed(s). } & \text { Editor(s) } \\ \text { EEC } & \text { European Economic Community } \\ \text { ERC } & \text { Esquerra Republicana de Catalunya } \\ \text { Et al. } & \text { Etalii } \\ \text { ETS } & \text { European Treaty Series } \\ \text { EU } & \text { European Union } \\ \text { EUDO } & \text { European Union Democracy Observatory on } \\ \text { Ff. } & \text { Abidem } \\ \text { Ibid. } & \end{array}$


ICJ

i.e.

ILC

JORF

LNTS

MEP

N-VA

OJ

$P(p)$.

SEW

S.C.R.

SNP

TEU

TFEU

UN

UNTS
International Court of Justice

id est

International Law Commission

Journal Officiel de la République Française (French official gazette)

League of Nations Treaty Series

Member of the European Parliament

Nieuw-Vlaamse Alliantie

Official Journal

page(s)

Sociaal Economische Wetgeving, Tijdschrift voor Europees en economisch recht

Supreme Court Reports (Canada)

Scottish National Party

Treaty on European Union

Treaty on the Functioning of the European Union

United Nations

United Nations Treaty Series 


\title{
Glossary of Latin terms
}

\author{
A priori Lit.: from the earlier \\ Ab initio from the beginning \\ Ad litem Lit.: for this action. Guardian ad litem someone \\ chosen by a law court to do something for another \\ person when that person is not able to do it him/ \\ herself
}

Conditio sine qua non a necessary condition without which something is not possible

De facto factually; in fact

De iure legally

Eo nomine by that name

Ex lege by operation of the law, automatically

Ex nunc without retroactivity

Ex tunc with retroactivity

Exempli gratia for example

Inter alia among other things

Ipso iure by the law itself; by operation of the law

Iure sanguinis by ius sanguinis

Iure soli $\quad$ by ius soli

Ius sanguinis Lit.: right of the blood: a person acquires the nationality of a parent at birth or by the establishment of a child-parent family relationship. 
Ius sanguinis a matre Lit:: right of the blood from the mother: a person acquires the nationality of the mother at birth or by the establishment of a child-mother family relationship.

Ius sanguinis a patre Lit:: right of the blood from the father: a person acquires the nationality of the father at birth or by the establishment of a child-father family relationship.

Ius soli

Lit.: right of the soil: a person acquires the nationality of his country of birth

Perse by or in itself; intrinsically

Prima facie Lit.: at first sight

Status quo existing state of affairs

Stricto sensu in the restricted sense; in the narrow sense

Supra above

Sui generis Lit.: in a class or group of its own: not like anything else

Vice versa Lit.: in-turned position 


\section{Glossary of legal terminology related to State succession}

Predecessor State:

Successor State

Continuing State:

Right of self-determination:

External self-determination:

The exercise of the external selfdetermination amounts to right to independent Statehood

Internal self-determination: The exercise of the internal selfdetermination does not amount to right to independent Statehood, but to recognition and protection of particular groups' culture and identity within the territory of an existing State. 
Remedial secession:

Succession in respect of part of territory:

Unification of States:

Separation of part(s) of a State: Category of State succession that takes

Dissolution of a State: place when a part or parts of the territory of a State separate to form one or more States, whether or not the predecessor State continues to exist.

Solution of last resorts whereby a particular group within the territory of an existing State is denied basic democratic freedoms and is subjected to severe human rights abuses.

Category of State succession that takes place when part of the territory of a State becomes part of the territory of another State. Also falling under this general category is the transfer of part of the territory of a State, i.e., the situation where a dependent territory becomes part of the territory of a State other than the State which was previously responsible for its international relations.

Category of State succession that takes place when two or more States unite and thereby form one successor State.

Category of State succession that takes place when a State dissolves and ceases to exist and the parts of the territory of the predecessor State form two or more successor States. 



\section{Chapter 1: Introduction}

\section{State Succession "within" the European Union}

State succession is defined as the replacement of one State by another in the responsibility for the international relations of a certain territory. ${ }^{1}$ The phenomenon of State succession experienced its golden years in the decades following World War II, ${ }^{2}$ in particular during the decolonisation period. ${ }^{3}$ Furthermore, interest in this subject has been renewed as a result of discussions in some EU Member States with regard to the independence aspirations of parts of their territories. The independence

1 For further elaboration of concepts related to State succession see Chapter 2, section 1.

2 Jaques de Burlet, Nationalité des personnes physiques et décolonisation, Bruylant, Brussels, 1975. Compare also Karl Matthias Meessen, Die Option der Staatsangehörigkeit, Duncker and Humblot, Berlin, 1966. For older treaties on nationality and State succession, see: Maurice Costes, Des Cessions de Territoires. Envisagées dans leur príncipe et dans leurs effects relatifs au changement de souveraineté et de nationalité, Rivière and Diron, Paris and Toulouse, 1914; Josef L. Kunz, Die Völkerrechtliche Option, Hirt, Breslau, 1928, pp. 302-356; Emile Szlechter, Les options conventionelles de nationalité à la suite de cessions de territoires, Sirey, Paris, 1948, pp. 357-361.

3 Inter alia, Philippines (1946), Jordan (1946), Syria (1946), India (1947), Pakistan (1947), Sri Lanka (1948), South Korea (1948), North Korea (1948), Laos (1949), Indonesia (1945/1949), Libya (1951), Cambodia (1953), Vietnam (1954), Tunisia (1956), Morocco (1956), Ghana (1957), Malaysia (1957), Guinea (1958), Iraq (1958), Burkina Faso (1960), Cameroon (1960), Chad (1960), Republic of the Congo (1960), Côte d'Ivoire (1960), Gabon (1960), Mauritania (1960), Niger (1960), Sierra Leone (1961), Kuwait (1961) Uganda (1962), Jamaica (1962), Trinidad and Tobago (1962), Algeria (1962), Kenya (1963), Malta (1964), Rhodesia (1965), Barbados (1966), Guyana (1966), Botswana (1966), Lesotho (1966), Mauritius (1967), Swaziland (1967), Equatorial Guinea (1968), Bahrain (1971), Qatar (1971), Oman (1971), United Arab Emirates (1971), Bahamas (1973), Guinea-Bissau (1974), Angola (1975), Mozambique (1975), Cape Verde (1975), São Tomé and Príncipe (1975), Suriname (1975), Papua New Guinea (1975), Seychelles (1976), Djibouti (1977), Belize (1981), Antigua \& Barbuda (1981), Namibia (1990), Estonia (1991), Latvia (1991), Lithuania (1991), Ukraine (1991), Belarus (1991), Moldova (1991), Armenia (1991), Georgia (1991), Azerbaijan (1991), Kazakhstan (1991), Uzbekistan (1991), Tajikistan (1991), Kyrgyzstan (1991), Turkmenistan (1991), Slovenia (1991), Croatia (1991), Macedonia (1991), Bosnia and Herzegovina (1992), Eritrea (1993), Hong Kong (1997), Macau (1999), East Timor (2002), Montenegro (2006) or South Sudan (2011). On the specific cases of Spanish, Belgian and British decolonisation process after World War II see Chapter 2, section 6. 
claims of Catalonia, Flanders and Scotland ${ }^{4}$ have ignited a debate on the international and European legal framework that would be applicable in such an unprecedented situation, and in particular the consequences for its EU membership in the event of a potential independence of one of these territories. The presumption since the early stages of European integration was that Member States were fixed entities and that no State succession could ever take place within the EU. Yet the phenomenon of State succession has not been so uncommon from a historical perspective, and has more recently received increased attention in light of the Scottish Independence referendum, and in light of the outcome of the 23 June 2016 United Kingdom referendum on EU membership.

A Catalan, Flemish, or Scottish independence would be a unique event since it would be the first case of a break-up of an EU Member State. These cases would differ from other territorial changes that have already occurred in certain EU Member States, such as the German reunification in $1990 .{ }^{5}$ Historical precedents of State succession in a EU Member State include, inter alia, the independence of the French departments of Algeria in 1962, ${ }^{6}$ the transfer of Dutch New Guinea also in $1962^{7}$ and the independence of the Comoros Islands from France

$4 \quad$ For the sake of consistency, the reference to the three devolved regions studied in this book will follow the alphabetical order i.e., Catalonia, Flanders and Scotland. The reference to the three Member States of which these regions are a part will follow the order already established, i.e., Spain, Belgium and the United Kingdom. The term "region" is used to identify a territorial entity within a State that is distinguished from neighbouring regions.

5 Treaty on the Unification of Germany (Vertrag zwischen der Bundesrepublik Deutschland und der Deutschen Demokratischen Republik über die Herstellung der Einheit Deutschlands (Einigungsvertrag), BGBl. 1990 II 889, Bulletin (Presse und Informationsamt der Bundesregierung) No. 104/S. 877 (1990), East Berlin, 31 August 1990. Another example of territorial change that involved two current EU Member States was the transfer of the Saar, under French sovereignty, to the Federal Republic of Germany in 1957. See the Treaty of Luxemburg (Vertrag von Luxemburg: Vertrag zwischen der Bundesrepublik Deutschland und der Französischen Republik zur Regelung der Saarfrage), Bilateral agreement between the Federal Republic of Germany and the French Republic, Luxembourg, 27 October 1956, BGBl. 1956 II 1589. One should note that the transfer of the Saar took place before the establishment of the EEC (the Treaty establishing the EEC of 25 March 1957 entered into force on 1 January 1958) and before the Treaty on European Union, which introduced the legal concept of citizenship of the Union for the first time. The Saar precedent is therefore not comparable with a potential Catalan, Flemish or Scottish independence.

6 Évian agreements (Les Accords d'Évian), reached between the French government and the Algerian Front de Libération Nationale's Gouvernement Provisoire de la République Algérienne, Évian-les-Bain (France), 18 March 1962, JORF 20 March 1962, 3019.

7 Agreement between the Republic of Indonesia and the Kingdom of the Netherlands 
in $1975,{ }^{8}$ although these cases seem more akin to the decolonisation process. ${ }^{9}$ Furthermore, these territories, which are now independent

concerning West New Guinea (West Irian), 15 August 1962, UNTS 437, p. 274-290.

8 Note that the Comoros Islands also experienced their own process of secession in the case of the island of Mayotte, which currently has the status of EU Overseas Territory. See Council Directive 2013/61/EU of 17 December 2013 amending Directives 2006/112/EC and 2008/118/EC as regards the French outermost regions and Mayotte in particular, OJ L (353) 5, 28 December 2013.

9 The Comoros Islands, enjoyed the status of territoire d'outre-mer according to the Loi no 46-2385 du 27 octobre 1946 sur la composition et l'élection de l'Assemblée de l'Union française, JORF 28 October 1946, 9178, were listed in Annex IV to the Treaty of Rome as Overseas Countries and Territories, that is, non-European territories associated with the EEC under operation of Articles 131-136 of the EEC Treaty.

In the case of Dutch New Guinea, on 1 October 1962, the Kingdom of the Netherlands transferred the Dutch New Guinea to the UNTEA (United Nations Temporary Executive Authority) which transferred this territory to Indonesia. However, previous to that transfer of territory, the Dutch New Guinea was listed in Annex IV to the Treaty of Rome as Overseas Countries and Territories. See Gerard-René de Groot, Achtentwintig Nederlanders? Bewerkte adviezen en casus over de toepassing van de Nederlandse nationaliteitswetgeving, Elsevier Overheid, 's Gravenhage, 2007, pp. 179-182. For a more detailed analysis see Daniel Gruss, "UNTEA and West New Guinea", in Armin von Bogdandy and Rudiger Wolfrum (eds.), Max Planck Yearbook of United Nations Law, vol. 9, 2005, pp. 97-126.

The situation of the French Algeria départments, which, like the départements de métropole, belonged to the EEC territory, was governed by Article 227(2) of the EEC Treaty. Thus, the provisions relating to free movement of goods, agriculture, with the exception of Article 40(4), liberalisation of services, rules of competition, the measures of safeguard provided for in Articles 108, 109 and 226, and the institutions were applicable from the date of the entry into force of the EEC Treaty. It should be noted that the first bilateral agreement between the EEC and Algeria was concluded in 1976, EEC-Algeria Cooperation Agreement, OJ L (263) 2, 26 April 1976. In the interim period between Algerian independence and the cooperation agreement with the EEC, the relevant EEC Treaty provisions were applied "by implication" and "without any official overtures either from the State or the Community". The same year of Algeria's independence, the Algerian president addressed a letter to the EEC Council of Ministers requesting the maintenance of the application of certain treaty provisions. The receipt of the letter was acknowledged by the Council on 24 January 1963, setting out the EEC's interest in the problem and its intention to study it. See further: Allan F. Tatham, "Don't Mention Divorce at the Wedding, Darling!: EU Accession and Withdrawal after Lisbon", in: Andrea Biondi et al (eds.), EU Law After Lisbon, Oxford University Press, 2012, p. 144 and Paul Tavernier, "Aspects juridiques des relations économiques entre la CEE et l'Algérie", Revue trimestrielle de droit européen, Vol. 8, 1972, pp. 9-10.

Notice that almost all overseas countries and territories listed in Annex IV of the original EEC Treaty are not mentioned in Annex II of the Treaty on the Functioning of the EU since most of them achieved independence during the decolonisation process. 
States,$^{10}$ are arguably not States, that could apply for EU membership. ${ }^{11}$

The case of Greenland also deserves to be mentioned. Greenland was incorporated into the Danish Kingdom as a province in $1953 .{ }^{12}$ In 1973 , when Denmark acceded to the European Communities, ${ }^{13}$ Greenland became part of the Community territory, despite $70 \%$ of Greenlanders having voted against Denmark joining the Community in the accession referendum. ${ }^{14}$ After achieving a certain degree of internal autonomy in $1979,{ }^{15}$ the Greenlandic Parliament asked to withdraw from the Community in order to obtain full control of its fisheries policy. ${ }^{16}$ Following almost three years of negotiations between the Greenlandic Government and the Danish Government, and between the Danish Government and the European Commission; ${ }^{17}$ Greenland ceased to be part of the Communities on 1 February $1985,{ }^{18}$ by virtue of a statute of association with the Communities through the overseas countries and territories formula. ${ }^{19}$

10 At least in the cases of the Comoros Islands and Algeria.

11 Article 49 TEU: Any European State which respects the values referred to in Article 2 and is committed to promoting them may apply to become a member of the Union (emphasis added, GMG).

12 In 1953, the Danish Constitution rescinded Greenland's colonial status. Greenland was incorporated not as a colony but as a province, also extending Danish citizenship to Greenlanders. See https://www.constituteproject.org/constitution/ Denmark 1953.pdf

13 Treaty between the Kingdom of Belgium, the Federal Republic of Germany, the French Republic, the Italian Republic, the Grand Duchy of Luxembourg, the Kingdom of the Netherlands (Member States of the European Communities), the Kingdom of Denmark, Ireland, the Kingdom of Norway and the United Kingdom of Great Britain and Northern Ireland concerning the accession of the Kingdom of Denmark, Ireland, the Kingdom of Norway and the United Kingdom of Great Britain and Northern Ireland to the European Economic Community and to the European Atomic Energy Community, OJ L (73) 5, 27 April 1972.

14 Frederik Harhoff, "Greenland's withdrawal from the European Communities", Common Market Law Review, Vol. 13, 1983, p. 17.

15 Ibid., p. 18.

16 Allan F. Tatham, "Don't Mention Divorce at the Wedding, Darling!: EU Accession and Withdrawal after Lisbon", in: Andrea Biondi et al. (eds.), EU Law After Lisbon, Oxford: Oxford University Press, 2012, pp. 145-147.

17 On those negotiations see: Derrick Wyatt in his suplementary written evidence submitted to the House of Lords in 2016 para. 6, available at http://data.parliament. uk/writtenevidence/committeeevidence.svc/evidencedocument/europeanunion-committee/the-process-of-leaving-the-eu/written/32079.html.

18 Treaty Amending, With Regard to Greenland, the Treaties Establishing the European Communities, OJ L (29) 1, 2 January 1985.

19 Greenland's departure from the EEC did not affect Denmark's membership, although the territorial scope of application of the Treaties changed as a result. Despite being an autonomous territory since 1979, Greenland remains part of Denmark and has yet to gain independence. See James Crawford and Alan Boyle, Annex A-Opinion: 
The most recent example of a Member State territory separating from the EU is Saint Barthélemy. This French Antilles island separated from the French Overseas Department of Guadeloupe ${ }^{20}$ in a referendum held in 2003, ${ }^{21}$ thereby acquiring the status of "overseas collectivity" ${ }^{22}$ On 1 January 2010, in accordance with Council Decision 2010/718/EU, ${ }^{23}$ the island of Saint Barthélemy ceased to be part of the EU and it subsequently became an Overseas Country or Territory. ${ }^{24}$

The examples of Greenland and Saint Barthélemy, however, do not embody the independence of devolved territory of a Member State but rather represent a territorial redefinition of the Kingdom of Denmark and the French Republic respectively. Furthermore, it is important to acknowledge that the new status of these Danish and French territories did not have consequences for the EU citizenship of the Danish and French nationals of those territories. This is due to the fact that both Denmark and France have a unitary nationality system: the nationals of those countries living in overseas territories have the same nationality status as nationals living in the metropolitan areas and they are, therefore, citizens of the Union. ${ }^{25}$

Referendum on the Independence of Scotland-International Law Aspects, Scotland Analysis: Devolution and the Implications of Scottish Independence, United Kingdom Government, 2013, p. 99. Kochenov argues that due to its new status as Overseas Country or Territory, Greenland never left the EU. See Dimitry Kochenov, "EU Citizenship and Withdrawals from the Union: How Inevitable Is the Radical Downgrading of Rights?", LEQS paper, No. 111, 2016, p. 20.

20 As a municipality forming part of Guadeloupe, Saint Barthélemy enjoyed the status of overseas region and department of France, being integral part of both, French and EU territory. Phoebus Athanassiou and Stéphanie Laulhé Shaelou, "EU Accession from Within?-An Introduction", Yearbook of European Law, 2014, pp. 36-37.

21 See Justin Daniel, "La consultation populaire du 7 décembre 2003 et ses implications", Pouvoirs dans la Caraïbe, 15, December 2003.

22 Communauté d'Outre Mer, in accordance with article 74 of the French Constitution.

23 EU Council Decision 2010/718/EU of 29 October 2010 amending the status with regard to the European Union of the island of Saint Barthélemy, OJ L (325) 4, 9 December 2010.

24 Yves Gounin, "Les dynamiques d'éclatements d'États dans l'Union européenne: cassetête juridique, défi politique", Politique étrangère, Vol. 4, 2013, p. 17.

25 Neither Denmark nor France lodged a declaration on the occasion of the Danish, respectively French ratification of the Maastricht Treaty in order to define who are nationals for European purposes [OJ C (348) 1, 31 December 1992]. The case of the Danish inhabitants of the Faroe Islands is noteworthy: whilst they are Danish nationals, they are not European citizens. See Gerard-René de Groot, "Towards a European Nationaity Law", in Hildegard Schneider (ed.): Migration, Integration and Citizenship, A Challenge for Europe's Future, Vol. I, Forum Maastricht, May 2005, pp. 16-23. 
It follows therefore that there is no relevant precedent which can be applied by analogy to the Spanish, Belgian or British cases. ${ }^{26}$ Neither the Algerian independence, ${ }^{27}$ nor the withdrawal of Greenland and Saint Barthélemy can be fully compared to the hypothetical scenario of a European part of a Member State seceding. The respective situations in Catalonia, Flanders and Scotland thus pose a question for which the EU has no direct precedent to rely on. Although the Treaties have provided for an accession procedure for States to join the $\mathrm{EU}^{28}$ and, after the entry into force of the Lisbon Treaty, ${ }^{29}$ to withdraw, ${ }^{30}$ there is currently no provision in the Treaties to address the separation of a devolved region of a Member State that wishes to remain within the EU as an independent Member State. The presumption has been that the EU territory could only expand through enlargement, not that it could contract via the operation of a State succession in one of its Member States.

The culmination of a process of this nature in Catalonia, Flanders or Scotland distinguishes it from previous territorial changes which have occurred in the European Union. ${ }^{31}$ The independence of part of the territory of an EU Member State and its accession to the EU itself will have a significant impact on the enjoyment of one of the major achievements of the European integration process, i.e., the status of citizen of the Union. ${ }^{32}$ The enjoyment of that status by nationals of Member States involved in an independence or separation process could be jeopardised as a result of the potential loss of the nationality of that Member State. Similarly, European

26 Sionaidh Douglas-Scott, "How Easily Could an Independent Scotland Join the EU?", Oxford Legal Studies Research Paper No. 46, 2014, p. 7.

27 The Algerian case is somewhat similar to the current situation. However, this took placed in 1962, long before the Treaty on European Union first introduced the legal concept of citizenship of the Union and the freedoms attached thereto.

28 Article 49 TFEU.

29 The Lisbon Treaty entered into force in December 2009 - it is composed by consolidated versions of the Treaty on the European Union (TEU), the Treaty on Functioning of the European Union (TFEU) and the legally binding EU Charter of Fundamental Rights which includes one title (Title V) on Citizens' Rights.

30 Article 50 TFEU.

31 Compare Henri de Waele, "Afscheiding van delen van EU-lidstaten -de Europeesrechtelijke implicaties", SEW, 2016, p. 4. See also David Edward, "European Law and the Separation of Member States", Fordham International Law Journal, 2013, pp. 1151-1168; Merijn Chamon and Guillaume Van der Loo, "The Temporal Paradox of Regions in the EU Seeking Independence: Contraction and Fragmentation versus Widening and Deepening?", European Law Journal, 2014, pp. 613-629.

32 The concept of citizen of the Union was introduced by the Maastricht Treaty [European Union, Treaty on European Union (Consolidated Version), Treaty of Maastricht, 7 February 1992, OJ (C 191) 1; 29 July 1992]. See Chapter 4, section 2. 
citizens of other nationalities residing in the territory of the potential new State could also be affected, since their status as citizens of the Union would not guarantee them the exercise of free movement rights in the territory of the newly independent State..$^{33}$ The same could apply for third country nationals, citizens of non-EU Member States residing in the potential new State, who also enjoy certain rights under the operation of EU law. ${ }^{34}$

This thesis therefore analyses the effects of a potential independence -and subsequent State succession scenario- ${ }^{35}$ process on the EU citizenship and related rights of nationals of the Member State concerned and involved in the independence process itself. For this reason, given the intrinsic link between citizenship of the Union and Member States' nationality ${ }^{36}$ -the acquisition or loss of the nationality of a Member State implies the enjoyment or loss of EU citizenship- it is necessary to determine how nationality issues would be settled in a State succession scenario. Nationality is still within the sovereign domain of the Member States. However, while domestic law governs questions on acquisition and loss of nationality, international and EU law impose certain restrictions and standards on this sovereign discretion. Thus it is necessary to conduct a study into the international legal rules and principles that govern nationality issues in the context of State succession, together with the European and domestic rules and legal principles that may apply to that scenario.

33 Note that the expression "newly independent State" is used in the 1978 Vienna Convention on the Succession of States in Respect of Treaties and the 1983 Vienna Convention on the Succession of States in Respect of Property Archives and Debts to refer to "a successor State the territory of which, immediately before the date of the succession of States, was a dependent territory for the international relations of which the predecessor State was responsable". That is, to refer to successor States created in the context of the decolonisation process. Here, this expression is used to generally refer to a newly independent Catalan, Flemish or Scottish State that may be created in the context of a potential independence process with no link to a colonial rule. See Chapter 2, section 1.2.

34 See Dimitry Kochenov, "Ius Tractum of Many Faces: European Citizenship and the Difficult Relationship between Status and Rights", Columbia Journal of European Law, Vol. 15, No. 2, 2009, pp. 222-233.

35 See Chapter 2, section 1, for the definition of State succession and the concepts of predecessor state and successor State.

36 According to Article 20(1) TFEU, "Every person holding the nationality of a Member State shall be a citizen of the Union. Citizenship of the Union shall be additional to and not replace national citizenship". The issue of the link between the nationality of an EU Member State and the citizenship of the Union is further elaborated in Chapter 4 , section 2 . 
In this project, neither Public International Law nor EU law can be ignored. No State operates in a vacuum but rather it interacts with other States as part of an international community. ${ }^{37}$ In this regard, the possible accession of a newly created State (e.g. a new Catalan, Flemish or Scottish State) to the EU also plays a significant role. At first glance, international law does refer the question of automatic accession back to the constituent instruments of international organisations..$^{38}$ It is therefore necessary to investigate whether a continued membership could be justified in light of the EU treaties. Furthermore, an analysis of the independence movements in Catalonia, Flanders and Scotland, from the domestic perspective of the Member States at stake, together with a historical reference to the genesis of these independence movements will be conducted.

The main objective of this thesis is to address the legal consequences of a potential State succession scenario in the context of international, European (EU and Council of Europe), and domestic law, in order to provide guidance for a situation that could potentially arise in regions such as Catalonia, Flanders and Scotland, as well as other separatist movements which exist within EU Member States. ${ }^{39}$

\section{Research Questions}

The present research project focuses on the study of EU citizenship status and the laws governing nationality in the context of a potential State succession scenario within the EU. The novelty of the situation and the

37 Manuel Diez de Velasco, Instituciones de Derecho Internacional Público, Tecnos, Madrid, 2013 (18 th $^{\text {th }}$ edition), p. 261; Julio D. González Campos, Luis I. Sánchez Rodríguez, Paz Andrés Sáenz de Santa María, Curso de Derecho Internacional Público, Aranzadi, Navarra, 2008 ( $4^{\text {th }}$ edition revised), p. 497; Paz Andrés Sáenz de Santa María, Sistema de Derecho Internacional Público, Aranzadi, Navarra, 2014 ( $3^{\text {rd }}$ edition), pp. 19-24. See Chapter 2, section 1.

38 On the membership of international organisations, see Chapter 2, section 3.

39 There are other regions within the EU where independence is being discussed, i.e., the Basque Country in Spain, the Faroe Islands in Denmark, Brittany in France, South Tyrol in Italy, Azores in Portugal or even Friesland in the Netherlands. For instance, in the case of Italy, see Eve Hepburn, "The "Domino Effect" from Scotland's Referendum is Increasing Demands for Independence in Italian Regions", http://blogs.lse.ac.uk/europpblog/, 9 September 2014. See also Catherine Brölmann and Thomas Vandamme (eds.), Secession within the Union: Intersection points of International and European Law, Amsterdam Centre for European Law and Governance and Amsterdam Center for International Law, July 2014. For Italy and the Basque Country see Roberta Medda-Windischer and Patricia Popelier (ed), Pro-independence Movements and Immigration: Discourse, Policy and Practice, Brill Nijhoff, Leiden Boston, 2016. 
lack of specific EU law provisions applicable to deal with such a situation, evidence the need for legal research to answer questions related to the exercise of EU fundamental freedoms and rights, as well as to identify relevant international and regional standards. Special attention will be paid to the residence status -and rights attached thereto- of persons affected by the potential State succession in the EU.

The Maastricht Treaty ${ }^{40}$ introduced the concept of citizenship of the Union nearly twenty-five years ago. Article 20(1) TFEU re-asserts the concept of EU citizenship. That status is automatically conferred on every person holding the nationality of a Member State. As claimed by the CJEU, citizenship of the Union is intended to be the fundamental status of nationals of the Member States. ${ }^{41}$ Article 20 TFEU precludes national measures that, in effect, deprive citizens of the Union of their genuine enjoyment of the substance of the rights conferred by virtue of their status as European citizens. Whilst the conferral of rights associated with nationality status remains wholly within the exercise of the sovereign powers of the Member States, the CJEU has held that the eventual withdrawal of Member State nationality, once conferred, may bring matters within the ambit of EU law. Thus, in Rottmann $v$ Bavaria ${ }^{42}$ the Grand Chamber of the CJEU found that the status of citizenship of the Union requires a Member State to exercise its powers to deprive or withdraw an individual's nationality in a manner compatible with the principles of EU law. The Court has since clarified that while this is in principle a matter for national law, Member States must act in such a way that a person who is a citizen of the Union is not substantially deprived of their EU citizenship rights.

Given the CJEU's dogmatic emphasis on the primacy of EU citizenship as being the fundamental status of nationals of the Member States, it is necessary to explain how independence processes could affect that status and the rights flowing therefrom, and to assess the role that EU law can play in this scenario. The following questions therefore need to be answered:

- Would the citizens of regions succeeding an EU Member State -such as those of Catalonia, Flanders or Scotland- cease to enjoy those rights and freedoms if these devolved regions become independent States?

- What would be the legal situation of EU citizens from other Member States residing in the potential new States?

40 European Union, Treaty on European Union (Consolidated Version), Treaty of Maastricht, 7 February 1992, OJ C (191) 1; 29 July 1992.

41 See inter alia, Case C 34/09, Ruiz Zambrano [2011] ECR I-01177.

42 Case C-135/08, Rottmann [2010] ECR I-01449. 
- What would be the status of nationals of the potential new States residing in another EU Member State?

- To what extent would EU law and the CJEU case-law influence the nationality act of the potential new State?

- Would there be any EU Law influence on the (re)action of the remaining Member State regarding its nationality law and policy?

- What about the situation of third country nationals ${ }^{43}$ residing in the potential new States, in particular those who possess long-term resident status?

\section{Scope}

The primary focus of this thesis is of a legal nature since the subject matter of the research concentrates on the consequences of State succession within the EU for the laws governing nationality and EU citizenship status. Despite the unquestionable existence of a political dimension to any independence debate, the approach and method implemented in this study is of a purely legal nature. Any wider political considerations that have an impact on the research questions are not discussed or covered in this analysis. ${ }^{44}$

43 Here the term third country national (TCN) is used as an EU legal concept. Thus, for the purposes of EU law, a TCN "means any person who is not a citizen of the Union within the meaning of 17(1) of the Treaty [current Article 20(1) of the TFEU]". This definition is provided in Article 2(a) of Council Directive 2003/109/ EC of 25 November 2003 concerning the status of third-country nationals who are long-term residents, OJ L (016) , 23 January 2004 P. 0044 - 0053. Identical definitions can be found in, inter alia, Article 2(a) of Council Directive 2003/86/ EC of 22 September 2003 on the right to family reunification, OJ L (251), 3 October 2003, pp. 12-18; Article 2(a) of the Council Directive 2004/114/EC of 13 december 2004 on the conditions of admission of third-country nationals for the purposes of studies, pupil exchange, unremunerated training or voluntary service OJ L (375), 23 December 2004, pp. 12-18; Article 2(a) of the Council Directive 2004/81/EC of 29 April 2004 on the residence permit issued to third-country nationals who are victims of trafficking in human beings or who have been the subject of an action to facilitate illegal immigration, who cooperate with the competent authorities, OJ L (261), 6 August 2004, pp. 19-23; or Article 2(a) of the Council Directive 2009/50/ EC of 25 May 2009 on the conditions of entry and residence of third-country nationals for the purposes of highly qualified employment, OJ L (155), 18 June 2009, pp. 17-29.

44 For further clarification on the dimensions being excluded from the scope of this research see section 4 of the current Chapter. 


\subsection{Nationality Law}

This thesis approaches "nationality" as a legal concept. It does not focus on the linkages between nationality and identity, ethnicity or the feeling of belonging. ${ }^{45}$ However, the legal term nationality is not free from controversy. Like many legal concepts, it is rooted in the Roman law tradition. ${ }^{46}$ The status of civis or "Roman citizen" was essential to invoke the application of Roman law. People who did not possess this status could not claim the application of legal rules, such as the peregrini and latini. It was the Emperor Caracalla, in 212 A.D., who granted "Roman citizenship" to all free inhabitants living within the borders of the Roman Empire. ${ }^{47}$ Only "Roman citizens" were allowed to enjoy full civil and political rights, including the right to hold public office, the right to enter into contracts and own property, the right to enter into a legally recognised marriage, to access to court and to be protected against abuses of power. ${ }^{48}$

Today, almost 2,000 years later, this idea of a link between the individual members of a group and a "political entity", together with the consequences of that link in terms of enjoyment of rights and duties, is still present within the legal concept of nationality. However, this is not the only term used in this field of law. As noted by de Groot and Vonk, the terms nationality and citizenship can be conflated, leading to a certain degree of confusion, due to the diverse meanings drawn from different "legal traditions and academic disciplines". ${ }^{49}$

In the English language this terminological confusion becomes glaringly apparent since the term nationality is used to denote the legal link of the individual with a State, but British citizen status is the "most privileged status that one can acquire in that it entails the right to enter the United Kingdom". ${ }^{50}$ The likelihood of confusion is heightened when one realises

45 Peter J. Spiro, "A New International Law of Citizenship", American Journal of International Law, Vol. 105, No. 4, October 2011, p. 694.

46 Wolfgang Kunkel and Martin Schermaier, Römische Rechtsgeschichte, Böhlau, Köln/ Weimar/Wien, 2005 (14 ${ }^{\text {th }}$ edition), pp. 15-17.

47 Constitutio Antoniniana or Edict of Caracalla. See Paul Keresztes, "The Constitutio Antoniniana and the Persecutions under Caracalla", The American Journal of Philology, Vol. 91, No. 4, October 1970, p. 449.

48 Andrew Lewis, "Slavery, Family, and Status" in: David Johnston (ed.), The Cambridge companion to Roman Law, Cambridge, 2015, pp. 171-172.

49 Gerard-René de Groot and Olivier Willem Vonk, International standards on nationality law: text, cases and materials, Wolf Legal Publishers, Oisterwijk, 2016, p. 3.

50 A similar distinction can be found in the United States, where American citizens enjoy a more privileged status over American nationals. Gerard-René de Groot and Olivier Willem Vonk, International standards on nationality law: text, cases and 
that British citizenship is regulated in part I of the British Nationality (not citizenship) Act 1981, ${ }^{51}$ which also establishes and regulates, inter alia, British Overseas Territories Citizenship and British Overseas Citizenship. These remarks have to be taken into consideration when assessing the situation in the United Kingdom in general, and Scotland in particular.

In the cases of the other two Member States under discussion, Belgium and Spain, the distinction between nationality and citizenship is clearer. Aligned with the continental European tradition, the term nationality (nationalité/nationaliteit in French/Dutch; nacionalidad in Spanish) is understood as the legal bond between an individual and the State. It is also the term used in the Code de la nationalité belge or Wetboek van de Belgische nationaliteit ${ }^{52}$ and in the Código Civil español (Spanish Civil Code). ${ }^{53}$ The term citizenship (citoyenneté/burgerschap in French/Dutch; ciudadanía in Spanish) implies a reference to the full entitlement of political rights or the political membership of a State. ${ }^{54}$

Nationality is also a legal concept in international law. ${ }^{55}$ The International Court of Justice (ICJ) defined nationality in the Nottebohm case as the

"legal bond having as its basis a social fact of attachment, a genuine connection of existence, interests and sentiments, together with the existence of reciprocal rights and duties. It may be said to constitute the juridical expression of the fact that the individual upon whom it is conferred, either directly by the law or as the result of an act of the authorities, is in fact more closely connected with the population of the State conferring nationality than with that of any other State". ${ }^{56}$

materials, Wolf Legal Publishers, Oisterwijk, 2016, p. 3.

51 British Nationality Act 1981, 1981 Chapter 61, 30 October 1981.

52 Code de la nationalité belge/Wetboek van de Belgische nationaliteit, Belgian Official Gazette (Belgisch Staatsblad, Moniteur Belge), 12 July 1984.

53 Código Civil, Royal Decree 24 July 1889, Madrid Official Gazette (Gaceta de Madrid) No. 206, 25 July 1889, pp. 249-259. See Articles 17 - 28 of the Spanish Civil Code containing the provisions on acquisition and loss of Spanish nationality.

54 For a further study on the relationship between the term nationality and citizenship see Gerard-René de Groot, "Towards a European Nationality Law", in: Hildegard Schneider (ed.), Migration, Integration and Citizenship, A Challenge for Europe's Future, Vol. I, Forum Maastricht, May 2005, pp. 13-53.

55 Jeffrey L. Blackman, "State Successions and Statelessness: The Emerging Right to an Effective Nationality under International Law", Michigan Journal of International Law 19, Vol. 4, 1998, p. 1147.

56 Nottebohm Case (Liechtenstein v. Guatemala); Second Phase, International Court of Justice (ICJ), 6 April 1955, p. 23. 
Likewise, the European Convention on Nationality (ECN) reasserts the formal nature of the link between an individual and the State, stipulating that nationality means

"the legal bond between a person and a State and does not indicate the person's ethnic origin". ${ }^{57}$

However, there exists no general right to nationality in international law. Article 15(1) of the Universal Declaration of Human Rights ${ }^{58}$ and Article 19 of the American Declaration of the Rights and Duties of Man $^{59}$ aimed to establish an individual human right to nationality, but in a legally nonbinding manner. ${ }^{60}$ The ECN stresses the right of everyone to a nationality amongst its principles, but only 20 States have acceded to that convention. Only the American Convention of Human Rights establishes a right to the nationality of a specific State ${ }^{61}$ and, despite the findings of the InterAmerican Court of Human Rights in Advisory Opinion 4/84, ${ }^{62}$ the right to nationality is far from being "generally accepted today"63 as a human right. ${ }^{64}$ Thus, the legal concept of nationality has a twofold dimension: national and international.

In line with the terminology used in Public International Law, this thesis also uses the term nationality to denote the legal link of individuals with a State. However, when referring to nationality law in the United Kingdom, the terminology of the British Nationality Act will be followed, which implies that, in the British context, the word citizenship will be used.

57 Council of Europe, European Convention on Nationality, 6 November 1997, ETS 166, Article 2 (a).

58 UN General Assembly, Universal Declaration of Human Rights, 10 December 1948, 217 A (III).

59 Inter-American Commission on Human Rights (IACHR), American Declaration of the Rights and Duties of Man, 2 May 1948.

60 Oliver Dörr (2006), "Nationality", in: R. Wolfrum (ed.), Max Planck Encyclopedia of Public International Law, Oxford: Oxford University Press, para. 7.

61 Organization of American States (OAS), American Convention on Human Rights, "Pact of San Jose", Costa Rica, 22 November 1969, Article 20.

62 Advisory Opinion on Proposed Amendments to the Naturalization Provision of the Constitution of Costa Rica, OC-4/84, Inter-American Court of Human Rights, 19 January 1984.

63 Ibid., para. 32.

64 Marie-Bénédicte Dembour, When Humans Become Migrants. Study of the European Court of Human Rights with an Inter-American Counterpoint, Oxford: Oxford University Press, 2015, p. 136. 


\subsection{Territorial Scope}

Three EU Member States are the subject of study: Spain, Belgium and the United Kingdom. In other words, three regions of different Member States are analysed, i.e., Catalonia, Flanders and Scotland. The choice of these three regions is not arbitrary. These three regions have maintained unique historical, cultural, economic and political identities within the Member States of which they are part; they have benefitted from powers being devolved within their respective States; and the success of nationalist parties in these regions -Convergència i Unió (CiU) in Catalonia, ${ }^{65}$ NieuwVlaamse Alliantie (N-VA) in Flanders and the Scottish National Party (SNP) in Scotland-is well documented. The specific circumstances that have led these regions to seek independence within the EU are considered more comprehensively in Chapter $3 .{ }^{66}$ None of them have, at the time of writing, reached independent status and, in that sense, one could argue that the possible independence of a devolved part of an EU Member State is purely speculative. However, pathways to reaching independence have already been built and the eventuality of a State succession within the EU remains very much a plausible scenario.

The fact that the United Kingdom Government provided the legal basis ${ }^{67}$ to hold a referendum in Scotland provides already sound evidence of the nonspeculative character of the scenarios under discussion in this research project. Yet, far from being exhausted after the outcome of the Scottish referendum in 2014, the debate on the independence of Scotland has been reignited since the announcement of a referendum on whether the United Kingdom should leave the EU. Before the British General Election in May 2015, Prime Minister David Cameron declared his commitment to hold a referendum on Britain's EU membership by the end of 2017, should his Conservative Party win that general election outright. On 27 May 2015, the referendum was formally announced in the policy speech read by Queen Elizabeth II during the official State Opening of the British Parliament. On 2 June 2015, in a speech addressing the European Policy Centre, the First Minister of Scotland, Nicola Sturgeon, stated that the referendum on United Kingdom membership of the EU could trigger a new referendum in Scotland. ${ }^{68}$

65 CiU was a federation of two constituent parties, the larger Democratic Convergence of Catalonia (CDC) and its smaller counterpart, the Democratic Union of Catalonia (UDC). It was dissolved on 17 June 2015 due to their diverging positions on the Catalan independence process.

66 See Chapter 3, sections 2, 3 and 4.

67 Scottish Independence Referendum (Franchise) Act 2013, passed by the Parliament on 27 June 2013 and received Royal Assent on 7 August 2013.

68 First Minister of Scotland, Nicola Ferguson Sturgeon, speech addressing the 
In the meantime the "Brexit" referendum took place on 23 June $2016 .{ }^{69}$ The United Kingdom voted to leave the EU by $51.9 \%$ to $48.1 \%$. The leave option won the majority of votes in England -leave 53.4\%, remain 46.6\%and Wales -leave $52.5 \%$, remain $47.5 \%-$, while the remain option won the majority of votes in Northern Ireland $-44.2 \%$ leave, 55.8\% remainand every single council in Scotland voted to remain -leave 38\%, remain $62 \%-{ }^{70}$ The result of the United Kingdom European Union membership referendum showed clearly that Scotland wants to remain part of the EU and it actually triggered a new announcement of the Scottish Prime Minister to organise a second independence vote. ${ }^{71}$

In a rather different context the case of Catalonia is also illustrative. In December 2013, the Catalan Government announced an agreement between the four Catalan parties to hold a referendum on self-rule. For that purpose, the Parliament of Catalonia agreed to submit to the Spanish Parliament ${ }^{72}$ the Draft Organic Act which would delegate the competence to authorise, call, and hold a referendum on the political future of Catalonia to the Generalitat, the Catalan Government. ${ }^{73}$ The

European Policy Centre, Brussels, 2 June 2015, available at http://news. scotland.gov.uk/Speeches-Briefings/First-Minister-speech-to-European-PolicyCentre-1977.aspx. See Chapter 3, section 4.

69 See for more details Chapter 3, section 3.

70 Official data from the Electoral Commission available at http://www. electoralcommission.org.uk/find-information-by-subject/elections-andreferendums/upcoming-elections-and-referendums/eu-referendum/electorateand-count-information.

71 See the public statement of the Scottish First Minister, Nicola Sturgeon, made on 24 June 2016, available at http://news.scotland.gov.uk/Speeches-Briefings/FirstMinister-EU-Referendum-result-25ae.aspx\#downloads.

72 In conformity with Article 149(1) paragraph 32 of the Spanish Constitution, the State shall have exclusive competence on the authorization of popular consultations through the holding of referendums. Article 150(2) of the Spanish Constitution foresees that the State may transfer or delegate to the Autonomous Communities, through an Organic Act, some of its powers that by their very nature can be transferred or delegated. In January 2013, the Parliament of Catalonia made a formal petition asking the Spanish Parliament to transfer the necessary powers required to hold a referendum. This formal request, embodied in the 'Draft Organic Act delegating to the Generalitat the power to authorise, call and hold a referendum on the political future of Catalonia', comprised of a single point; the transfer of the aforementioned powers in accordance with Article 150(2) of the Spanish Constitution. In April 2014 and after a seven-hour debate, the act was rejected by an overwhelming majority of the Congress (eighty-six percent of all Spanish MPs voted against the transfer of the powers).

73 Resolution 479/X of the Parliament of Catalonia by which it was agreed to submit to the Presiding Board of the Congress the draft Organic Act delegating to the Generalitat of Catalonia the competence to authorise, call and hold a referendum on 
Spanish Parliament, however, voted against transferring that power, since it constituted an exclusive competence of the central State according to Article 149, paragraph 1, section 32 of the Spanish Constitution. Having exhausted the referendum route, efforts focused on what might be called the consultation route. However, it was not until 19 September 2014 -one day after the Scottish referendum- that the Catalan Parliament approved the Law on popular non-referendum consultations and civic participation. ${ }^{74}$ This Law provides the legal basis for the Decree calling the consultation on independence for Catalonia. This piece of legislation is framed within the plan for the National Transition of Catalonia, agreed between Convergència i Unió (CiU) and Esquerra Republicana de Catalunya (ERC) ${ }^{75}$ it also envisages the adoption of the "Declaration of Sovereignty and the Right to Decide of the People of Catalonia"76 and the creation of the Advisory Council for the National Transition. The Constitutional Court intervened to suspend both the law and the decree, as it did in relation

the political future of Catalonia (Resolución 479/X del Parlamento de Cataluña por la que se acuerda presentar ante la mesa del Congreso de los Diputados la proposición de ley orgánica de delegación en la Generalidad de Cataluña de la competencia para autorizar, convocar y celebrar un referéndum sobre el futuro político de Cataluña), Catalan Parliament Official Gazette (Butlletí Oficial del Parlament de Catalunya), 16 January 2013.

74 Law 10/2014, 26 September, on popular non-referendum consultations and civic participation (Ley 10/2014, de 26 de septiembre, de consultas populares no refrendarias y otras formas de participación ciudadana), Generalitat of Catalonia Official Gazette (Diari Oficial de la Generalitat de Catalunya), n. 6715, 27 September 2014.

75 Agreement on the X legislature period (Acord X legislature), CIU and ERC, 19 December 2012. The CIU (centre-right nationalist) was the party that received most of the votes in the regional elections but failed to win the absolute majority it sought. ERC (left nationalist and republican) came second in the poll. CIU and ERC ran their electoral campaign on an independence agenda. After a round of meetings, both political forces concluded a pact which was translated into the mentioned Agreement on X legislature.

76 The Resolution approving the Declaration of Sovereignty and the Right to Decide of the People of Catalonia was adopted in plenary session of the Catalan Parliament on 23 January, 2013 [Resolution 5/X of the Parliament of Catalonia, adopting the Declaration of sovereignty and right to decide of the people of Catalonia (Resolución 5/X del Parlamento de Cataluña, por la que se aprueba la Declaración de soberanía y del derecho a decidir del pueblo de Cataluña), Catalan Parliament Official Gazette (Butlletí Oficial del Parlament de Catalunya), 23 January 2013]. On 8 March 2013, the Spanish Government challenged the Resolution before the Constitutional Court. In March 2014, the Constitutional Court issued its ruling, in which the challenge was partly upheld (STC 42/2014, 25 March 2014). The Court declared the unconstitutionality and nullity of the first point of the Declaration, which states the following: 'Sovereignty. The people of Catalonia have, for reasons of democratic legitimacy, the nature of a sovereign political and legal subject'. See Chapter 3, section 2 . 
to the Declaration of Sovereignty and ruled on the unconstitutionality of both of these measures. ${ }^{77}$ Despite the legal and constitutional difficulties, the President of the Catalan Government, Artur Mas, announced early elections that were held on 27 September 2015, which symbolised a de facto referendum on independence from Spain. ${ }^{78}$

Flanders represents a unique situation in a unique federal system. According to Articles 1, 2 and 3 of the Belgian Constitution, Belgium comprises a central State, three Regions (Wallonia, Flanders and Brussels-Capital Region) and three Communities (the Flemish Community, the French Community and the German-speaking Community). Flemish nationalism was initially represented by the Volksunie, which later split into several new parties, i.e., the Vlaams Blok, Spirit and the Nieuw-Vlaamse Alliantie. ${ }^{79}$ The Vlaams Blok, which explicitly advocates Flemish independence, ${ }^{80}$ gained increasing electoral support during the 1990s and early 2000s. In 2010, the Vlaams Blok was convicted of incitement to discriminate and racism which led to its dissolution and its subsequent reorganisation as the Vlaams Belang. Consequently, the Nieuw-Vlaamse Alliantie became the largest political party in both Flanders and in Belgium. The success of the Nieuw-Vlaamse Alliantie set a new record: the longest period without a functioning national government. ${ }^{81}$ Lieven De Winter compared this situation to a forced marriage.

"Belgians are condemned to stick together [...]. They cannot divorce. They can make hell out of each other life in this forced marriage. Or they can try to make the best out of it, probably by enhancing their living apart together relationship". ${ }^{82}$

In the 2014 federal elections, the Nieuw-Vlaamse Alliantie increased its dominant position and it also became the largest party in the Flemish Parliament and in the Belgian delegation to the European Parliament, following the regional and European elections in 2014. Although the Nieuw-

77 STC 31/2015, 25 February 2015 and STC 32/2015, 25 February 2015.

78 See Chapter 3, section 2.

79 Michael Keating, "European Integration and the Nationalities", Question Politics \& Society, vol. 32 no. 3, September, 2004, p. 370.

80 Bruno Vandecasteele, Ferdi Deville \& Hendrik Vos, "Belgium, separatism, and the EU", Fair Observer, 2012, available at http://www.fairobserver.com/region/ europe/belgium-separatism-and-eu.

81 Christopher K. Connolly, "Independence in Europe: Secession, Sovereignty, and the European Union”, Duke Journal of Comparative \& International Law, Vol. 24, 2013, p. 66.

82 Lieven De Winter, "Belgium: from federalism to confederalism or to a big bang in 2014?", Cuadernos Manuel Giménez Abad, No. 4, December 2012, p. 29. 
Vlaamse Alliantie has been considered more moderate in its attempts to secure Flemish independence, paragraph 3 of its political manifesto is very clear in that the party must strive for an independent Flanders:

"Only by achieving autonomy — such as the peoples of Sweden, Ireland, Portugal and Greece- can Flanders truly develop itself within the European Union. That means that we have to strive for an independent Flanders." ${ }^{83}$

\subsection{Personal Scope}

The focus will be placed not only on the legal status of nationals from the seceding regions - Catalonia, Flanders and Scotland- who would reside in the new States or in the territory of other EU Member States, but also on the situation of those European citizens and third country nationals residing in the seceding territories. Determining how the independence of part of an EU Member State would affect the possession of EU citizenship by the nationals of the remaining EU Member State is essential. In a scenario in which the new State is, prima facie, a non-EU Member State, it must be asked whether the nationals of the remaining Member State that hold an evident link with the newly created State, will lose that previous nationality and by extension the rights and freedoms attached to EU citizenship.

Here, the question of EU membership plays a key role. From certain proindependence political positions it has been argued that the possible deprivation of the status of citizen of the Union would preclude an automatic exit from the EU. ${ }^{84}$ Thus, instead of acceding to the EU through the procedure contained in Article $49 \mathrm{TEU}$, it has been argued that the concept of European citizenship would allow the new political entity to remain a member of the $\mathrm{EU}$, resulting in a de facto internal enlargement of the EU. ${ }^{85}$

Conversely, however, a State must be created and exist for it to begin the EU accession process. This means that it is likely that there would be an unavoidable gap between the moment when the seceding region becomes

83 Translation by the author. The original text reads as follows: "Alleen door een autonomie te verwerven - zoals die van volkeren als de Zweden, de Ieren, de Portugezen of de Grieken - kan Vlaanderen zich binnen de Europese Unie echt ontplooien. Dat betekent dat we moeten streven naar een onafhankelijk Vlaanderen".

84 Chapter 2, section 3.

85 Jordi Matas et al, The internal enlargement of the European Union, Centre Maurits Coppieters, Brussels, 2010. An analysis on the question of membership is provided in Chapter 2, section 3. 
an independent State and the moment when the process of accession is culminated and it becomes an EU Member State. In other words, there would inevitably be an interim period between independence and accession in which the seceding region, the new State, would not fall under the territorial scope of the application of the Treaties. Thus, European citizens from other EU Member States and third country nationals residing in a seceding territory could find themselves in a situation in which certain rights and freedoms flowing from the application of EU law could not be exercised in that territory, at least on the basis of EU law, until its formal accession to the EU. This would lead to a high degree of legal uncertainty for those individuals affected by such State-driven processes, which consequently calls for an examination of the potential impact and legal consequences so as to avoid 'ad hocism' - only once succession happens. This kind of situation would be rather unsatisfactory from the perspective of European citizenship.

In any case, when analysing and assessing the different issues relating the status of natural persons in the context of State succession, it is important to realise that rules on attribution of nationality of the newly independent State and the continuation of nationality of the predecessor EU Member State should be drafted in such a way that they prevent migration movements after the publication of those rules. ${ }^{86}$ In other words, people affected by the State succession should not be forced to move in order to preserve a certain status, nationality or EU citizenship. Emigration spikes caused by the rules on the attribution and loss of nationality in a State succession context are neither in the interest of the newly independent State nor in the interest of the remaining EU Member State or the EU in general.

\section{Methodology and Structure}

This thesis primarily adopts a legal analytical methodology to consider the application of legal and doctrinal sources to the research questions underlined in section 2 above. These sources are primarily EU law, CJEU case law on EU citizenship and nationality law, international law, case law related to the phenomenon of State succession and the nationality of natural persons, the European Convention of Human Rights (ECHR) and the domestic nationality laws of Spain, Belgium and the United Kingdom.

86 For instance, in the independence of Suriname, one can observe emigration spikes clearly linked to the independence process itself. See Simona Vezzoli, Borders, independence and post-colonial ties: the role of the state in Caribbean migration, Maastricht: Boekenplan, 2015, pp. 135-142. 
The doctrinal legal research is conducted on the basis of a systematic review of scholarly contributions on the issues at stake in this book ${ }^{87} \mathrm{~A}$ comparative legal method ${ }^{88}$ has been deployed when examining the three selected EU Member States and the three potentially succeeding regions. In order to be able to compare not only the different situations of the regions where independence is being discussed in the three EU Member States, but also the different and intertwined legal systems that play a role in the explained scenario, it is necessary to describe first the situation in the three regions at stake and how international, regional and domestic law have dealt with the phenomenon of State succession and its effects on the nationality of natural persons. Following this descriptive analysis, the next step is to actually compare and explain the issues arising in that scenario and, finally, to evaluate the consequences of State succession on nationality and EU citizenship status. ${ }^{89}$

This methodology applies throughout the three pillars of the thesis: firstly, to the phenomenon of State succession; secondly, to European citizenship as a new element to be considered in the State succession context when dealing with nationality matters and the EU membership question; and thirdly, to the nationality laws of EU Member States.

Chapter 2 of this thesis is devoted to analysing the phenomenon of State succession. This chapter initially provides some notes on the issue of Statehood and then focuses essentially on the effects on the nationality status of natural persons and the question of continued membership to international organisations as a matter of Public International Law. There is a plethora of scholarly literature on State succession, as an institution of Public International Law. However, the State successions that may take place in Spain, Belgium or the United Kingdom present unique legal dilemmas, since the States involved are EU Member States and the regions where independence is being discussed want to remain in the EU. This part of the book applies a legal analytical methodology to study the main legal and doctrinal sources dealing with State succession in respect of nationality and membership to international organisations. Questions related to the right to self-determination of the seceding regions and the different State succession scenarios are also addressed. It will be examined from a Public

87 See the bibliography section of this book for a detailed overview.

88 Robert Cryer, Tamara Hervey and Bal Sokhi-Bulley, Research Methodologies in EU and International Law, Hart Publishing, Oxford and Portland, 2011, pp. 28-29.

89 The methodological approach follows the four steps of description, comparision, explanation and evalution. See on this methodological framework Marieke Oderkerk, "The need for a Methodological Framework for Comparative Legal Research. Sense and Nonsense of 'Methodological Pluralism' in Comparative Law", Nederlandse Vereniging voor Rechtsvergelijking, Vol. 73, 2016, p. 9. 
International Law and EU law perspectives, whether the seceding regions (the potential new States), would automatically remain in the EU after their independence. Currently, there are no specific EU provisions (in primary or in secondary law) dealing with State succession in a Member State. Ever since the adoption of the Westphalian model of a nation-state, ${ }^{90}$ and also from the perspective of Public International Law, territory has been one of the constituent elements of the existence of a State. ${ }^{91}$ The delimitation of the territory of a State is one of the last bastions of sovereign discretion for States themselves. This is no different for EU Member States. A State accedes to the EU with a defined territory, which can be enlarged or reduced on the basis of its will and in accordance with international law. Thus, territorial modifications that might take place in a Member State are issues that fall outside of the EU competences. ${ }^{92}$ The territory of each Member State is not delimited by the EU Treaties but by internal rules; this is the territory that it enjoys under international law. ${ }^{93}$ Furthermore, Articles 52 TEU and 355 TFEU, which establish the territorial scope of application of the Treaties, merely list each Member State eo nomine; and Article 4(2) TEU clearly states that the EU shall respect Member States' essential functions, including ensuring the territorial integrity of the State. In this regard, the absence of rules at the EU level cannot be characterised as a legal vacuum, but as the result of the interaction of international law, EU law and the exercise of sovereign competences at the domestic level.

Chapter 2 will also assess whether, from a legal perspective, the disruption in the application of EU law in seceding territories can be avoided. In order to accede to an international organisation, in this case the EU, the previous existence of a State is necessary. Article 49 TEU refers to "any European State" and "applicant State". Achieving statehood status implies the

90 Michael J. Kelly, "Pulling at the Threads of Westphalia: Involuntary Sovereignty Waiver, Revolutionary International Legal Theory or Return to Rule by the Great Powers?", UCLA Journal of International Law \& Foreign Affairs, Vol. 10, No. 2, 2007, pp. 372-383; Adolfo Miaja de la Muela, Introducción al Derecho Internacional Público, Atlas, Madrid, 1979 ( $7^{\text {th }}$ edition), pp. 455-459; Antonio Fernández Tomás, Ángel Sánchez Legido, Juan Miguel Ortega Terol, Manual de Derecho Internacional Público, Tirant lo Blanch, Valencia, 2004, pp. 44-45.

91 Article 1 of the 1933 Montevideo Convention on the Rights and Duties of States, which describes the qualifications for statehood as "(a) a permanent population; (b) a defined territory; (c) a government; and (d) a capacity to enter into relations with other States". Seventh International Conference of American States, Convention on Rights and Duties of States, 26 December 1933, LNTS, vol. 165.

92 In fact, Article 77(4) TFEU reads "This Article shall not affect the competence of the Member States concerning the geographical demarcation of their borders, in accordance with international law".

93 James Crawford, The Creation of States in International Law, Oxford Scholarship Online, Oxford, 2007 (2nd edition). 
independence from the EU Member State and, a priori, the independence from the Member State means leaving the territorial scope of application of the EU treaties. The former President of the European Council, Herman Van Rompuy, said in December 2013 -coinciding with the announcement of Catalan sovereignty query- that a new independent State would, by the fact of its independence, become a third country with respect to the Union and the treaties would, from the day of its independence, not apply anymore on its territory. ${ }^{94}$ Similarly, The Wall Street Journal reported on former European Commissioner Joaquin Almunia's statement:

"If one part of a territory of a Member State decides to separate, the separated part isn't a member of the European Union". ${ }^{95}$

Of course, one has to note the political nature of these declarations, since both persons had vested interests in preventing the independence of regions in their Member States of origin. The answers given by the European Commission to parliamentary questions on the topic do not deviate from that position. ${ }^{96}$

In light of international law and State practice on membership of international organisations, it is argued that the theory of the internal enlargement, ${ }^{97}$ which advocates the continued membership of the seceding regions on the basis of EU citizenship, would be difficult to follow.

94 Remarks by the President of the European Council Herman Van Rompuy, on Catalonia, EUCO 267/13 of 12 November 2013. See Roland Vaubel, "Secession in the European Union", Economic Affairs, Vol. 33, 2013, p. 295.

95 "Almunia Says Catalonia Would Need to Leave EU if it secedes From Spain", The Wall Street Journal, September 16, 2013, available at: http://online.wsj.com/news/ articles/SB10001424127887323527004579079031402636014.

96 Inter alia, parliamentary questions for written answer to the Commission, P-0524/04, written question by Eluned Morgan to the Commission, 12 February 2004, answer given by Mr Prodi on behalf of the Commission, 1 March 2004. See also the European citizens' initiative "Fortalecimiento de la participación ciudadana en la toma de decisiones sobre la soberanía colectiva", 1 April 2012, which objective was ensuring that citizens from seceding territories of Member States preserve EU citizenship. The Commission rejected the request for registration of that citizens' initiative based on the lack of EU competences on the matter [C (2012) 3689 final, 30 May 2012]. See also the parliamentary questions for written answer to the Commission E-000395/2012, E-007453/2012 and E-008133/2012. See for more details on the answer to questions on this issue to the EP Chapter 2, section 3.

97 See Jordi Matas et al, The internal enlargement of the European Union, Centre Maurits Coppieters, Brussels, 2010; and Advisory Council for the National Transition, Report No. 6, Paths for Catalonia's integration in the European Union, (2014). 
Section 5 of the chapter pays special attention to the international rules on the attribution of nationality upon independence. Despite the fact that nationality serves as a cornerstone for the definition of the initial body of citizens of a State, being a constituent element of State sovereignty, ${ }^{98}$ the power of States to determine who are its nationals is not unfettered. Under international law, nationality matters fall within the domaine réservé of the States but international law limits this sovereign prerogative. ${ }^{99}$ In 1923, the Permanent Court of International Justice (PCI) stipulated that States have exclusive jurisdiction on questions related to nationality but, at the same time, the Court noted that the extent of this jurisdiction varies with the development of international relations; it is therefore "an essentially relative question". ${ }^{100}$ Moreover, even as regards matters falling within this domain, the right of a State to use its discretion may be restricted by the operation of international obligations. ${ }^{101}$ In 1930, the Hague Convention on Certain Questions Relating to the Conflict of Nationality Laws reflected this approach of the Court, establishing that nationality matters fall within the domestic jurisdiction of the States, "[i]t is for each State to determine under its own law who are its nationals", ${ }^{102}$ and that such a sovereign competence shall be exercised within the limits of international law, "[t]his law shall be recognised by other States in so far as it is consistent with international conventions, international custom, and the principles of law generally recognised with regard to nationality". ${ }^{103}$

Finally, an analysis on the role during the decolonisation process of the three States under scrutiny takes place. Focus is placed on the most recent cases of decolonisation, i.e., colonies and protectorates that achieved independence -or in which territory a replacement of one State by another in the responsibility for the international relations happenedfrom Spain, Belgium and the United Kingdom after World War II. ${ }^{104}$ As

98 Lisa Pilgram, International Law and European Nationality Laws, European University Institute, Florence, Robert Schuman Centre for Advanced Studies, EUDO Citizenship Observatory, March 2011, p. 1.

99 Gerard-René de Groot, "The relationship between the nationality legislation of the Member States of the European Union and European citizenship", in: M. La Torre (ed.), European Citizenship: An Institutional Challenge, Milano: Giuffrè Editore/ Butterworths, 1998, p. 123. Gerard-René de Groot and Olivier Willem Vonk, International standards on nationality law: text, cases and materials, Wolf Legal Publishers, Oisterwijk, 2016, p. 41.

100 Advisory Opinion No. 4, Nationality Decrees Issued in Tunis and Morocco, 4, Permanent Court of International Justice, 7 February 1923, p. 24.

101 Ibid., p. 24.

102 League of Nations, Convention on Certain Questions Relating to the Conflict of Nationality Law, 13 April 1930, LNTS, vol. 179, p. 89, No. 4137, Article 1.

103 Ibid.

104 For the United Kingdom after the entry into force of the British Nationality Act 1948, i.e., 1 January 1949. 
has been mentioned already, the State succession precedents within the framework of the decolonisation process cannot be fully assimilated to the independence process in Catalonia, Flanders and Scotland. Nevertheless, the reaction of colonial powers towards nationality issues in that context can be helpful to observe certain patterns in the regulation of that status in the case of State succession. The three countries that are the subject of this research had a significant role during the colonial period. Therefore, the provisions that were drafted during the decolonisation process could be used to observe certain patterns in the regulation of nationality in cases of potential State succession.

Chapter 3 provides a historical analysis ${ }^{105}$ of the genesis and state of the art of the independence movements in Catalonia, Flanders and Scotland. This methodology can help ground the arguments provided by the proindependence forces. These three regions possess distinctive historical, cultural, economic and political features within the context of the States to which they belong. Some of these identifying traits are strictly linked to a historical moment in which these regions were not part of bigger political entity -neither Catalonia nor Scotland were originally Spanish or British territories. In the case of Flanders, this region already experienced a State succession as part of Belgium when Belgium became independent from the Netherlands.

Catalonia, Flanders and Scotland have benefitted from an important process of devolution of powers within their respective States. Thus, it can be argued that Catalonia, Flanders and Scotland have achieved significant internal self-determination. However, this does not go far enough to completely assuage independence movements, especially in Catalonia and Scotland, where these movements maintain their momentum.

Only Catalonia and Scotland have posed the independence question via a referendum -in the Scottish case- or "participatory process" -in the case of Catalonia-. In that context, the leading pro-independence political parties issued some proposals regarding granting an eventual Catalan or Scottish nationality upon independence. These proposals for the determination of State nationality $a b$ initio are analysed in this Chapter in light of international and regional standards. Furthermore, special attention is paid to the criteria used to define the electorate selected to vote in the independence referendums. One of the features that needs to be highlighted is that in the case of Scotland and also in the Catalan case, minors reaching the age of 16 years were allowed to participate in

105 Robert Cryer, Tamara Hervey and Bal Sokhi-Bulley, Research Methodologies in EU and International Law, Hart Publishing, Oxford and Portland, 2011, pp. 88-89. 
the independence decision-making process. From the onset, the reduction of the age requirement to 16 years is to be welcomed for reinforcing democratic responsibility and participation but it can raise difficult issues in latter stages: the $a b$ initio determination of nationals of an potential Catalan or Scottish independent State and the operation of the laws on the extension of the acquisition of nationality and loss of nationality from parents to minors. This latter point is analysed in Chapter 5 .

Chapter 4 of this thesis focuses on EU citizenship and nationality law. After studying the international rules and principles governing nationality issues in the context of the succession of States in Chapter 2, this chapter is devoted to a normative and systematic analysis of the anticipated consequences for European citizenship and the nationality status of nationals from the seceding regions, nationals from other EU Members States, and third country nationals residing in the seceding territories, in particular those who have acquired long-term resident status. This part examines legal sources such as EU law, CJEU case law on European citizenship and nationality law, ECtHR case law related to the enjoyment of rights attached to nationality as well as the domestic laws of Spain, Belgium and the United Kingdom.

Nationality matters arising in a State succession context are not terra incognita. But in the case of a State succession in the EU, the questions are not limited to possessing the nationality of the predecessor State or the successor State or the avoidance of statelessness. ${ }^{106}$ Novel questions regarding the enjoyment of the rights attached to the citizenship of the Union need to be addressed because of the existence of EU citizenship, attached to the nationality of the EU Member States, and in light of the CJEU's dogmatic emphasis on the primacy of EU citizenship as being the fundamental status of nationals of the Member States.

In answering the aforementioned questions, the nationality acts of the new States and remaining States are essential. The drafting of those pieces of legislation would fall within the competences of the newly created State and, at least in theory, within the exclusive competences of the remaining EU Member State. However, the CJEU ruling in Rottmann -dealing with loss of nationality- and the unprecedented intervention of the Commission in

106 Issues related to statelessness are further developed in Chapter 2. However, as brief introduction on the concept of statelessness, Article 1(1) of the Convention Relating to the Status of Stateless Persons defines "stateless person" as "a person who is not considered as a national by any State under the operation of its law". Convention Relating to the Status of Stateless Persons, 28 September 1954, UNTS, vol. 360, p. 117. 
the Maltese citizenship for sale programmes ${ }^{107}$-acquisition of nationality-, provide evidence that even when the matter falls within the competence of a Member State, national rules must pay due regard to the EU law when there is a nexus covered by it. Decisions of Member States in the field of nationality are not neutral with regard to other Member States and the EU. The same reasoning could be applied to a State that wants to become an EU Member State. ${ }^{108}$ To what extent would EU law and the CJEU case law influence the nationality act of the new State? And what would be the influence of EU Law on the reaction of the remaining EU Member State regarding its nationality law and policy?

Thus, the exercise of sovereign powers on nationality issues in a succession of States scenario in the EU, that is, by the predecessor State (an EU Member State) and by the new successor State ( $a b$ initio, non EU Member State) could be conditioned by EU law. A very inclusive approach of the newly created State in granting its nationality could even conflict with its desire to become an EU Member State. A generous granting of Catalan, Flemish or Scottish nationality to third country nationals could be detrimental to potential EU accession negotiations. Exempli gratia, if Catalonia, Flanders or Scotland would decide in favour of an inclusive residence-based policy when drafting its nationality act, this could include lawfully resident and settled third country nationals who at present may not yet qualify for Spanish, Belgian or British citizenship. Bearing in mind its willingness to "remain" within the EU, if these new States effectively grant nationality to a large group of third country nationals, through such an inclusive approach, these third country nationals would receive the right to exercise EU citizenship rights, which includes the rights of free movement and residence, and the right to work, in all other EU Member States. Similar issues could also arise if Scotland would decide to grant its citizenship to descendants of emigrants who do not currently qualify

107 Sergio Carrera Núñez and Guayasén Marrero González, "La ciudadanía europea en venta. El programa de venta de la nacionalidad maltesa: ¿una brecha en el principio de cooperación leal en el ámbito de la ciudadanía de la Unión?, (2014) 49 Revista de Derecho Comunitario Europeo, pp. 847-885. See also Sergio Carrera Núñez, "How Much Does EU Citizenship Cost? The Maltese Citizenship-for-Sale Affair: A Breakthrough for Sincere Cooperation in Citizenship of the Union?", Liberty and Security in Europe Paper No. 64, April, 2014 also in Sergio Carrera Núñez and Gerard-René De Groot (eds.), European Citizenship at the Crossroads, The Role of the European Union on Loss and Acquistion of Nationality, Wolf Legal Publishers, Oisterwijk, 2015, pp. 293-326.

108 Compare the discussions around the dual nationality schemes in Spain in view of the Spanish accession to the EEC. Elisa Pérez Vera, "El sistema español de doble nacionalidad ante la futura adhesión de España a las Comunidades Europeas", Revista de instituciones Europeas, 1991, pp. 65-73. 
for British citizenship because of limits on the intergenerational transfer of British citizenship. ${ }^{109}$ Such issues could play an essential role in the accession negotiations of these potential new States. However, the principle of sincere cooperation, already mentioned by Advocate General Maduro in his Opinion in the Rottmann case, ${ }^{110}$ would not become applicable to Catalonia, Flanders or Scotland until they become EU Member States.

On the other hand, the remaining EU Member State could react to the independence process with the establishment of stringent criteria regarding the retention of its nationality. This could lead to potential loss of the rights attached to the EU citizenship status, especially for those nationals residing abroad and with obvious linkages to the succeeding State. Beyond the independence of the devolved part of a Member State territory, an existing link between the predecessor and successor States should still be considered since it may result in a provision allowing for dual nationality. By allowing this dual nationality, exempli gratia, Catalan nationals would be able to enjoy the rights deriving from the EU citizenship status as holders of the Spanish nationality. In this sense, the reaction of the remaining State, which would remain subject to EU law as a Member State, could be reflected in substantial changes to its nationality law. One could anticipate that different nationality policies would arise in the different States under analysis. However, there is a common element that makes the analysis of different scenarios feasible: the new nationality legislation in the predecessor States must be compatible with the principles of EU law, ${ }^{111}$ whereas the successor States should also pay attention to these principles in the light of the accession negotiations. ${ }^{112}$

109 Jo Shaw, Citizenship in an independent Scotland: legal status and political implications, CITSEE Working Paper Series, vol. 34, (2013). Note that Belgian nationality law also has a limit of the intergenerational transfer of Belgian nationality of children born abroad (Article 8, Belgian Nationality Code). However, that limit was only introduced in 1985 and therefore did not have a major impact on the number of Belgian expatriates.

110 Opinion of Advocate General Poiares Maduro, in Case C-135/08, Rottmann [2010] ECR I-01449, para. 30. Advocate General Poiares Maduro stated that provisions of primary Community legislation and the general principles of Community law could restrict the legislative power of Member States in the sphere of nationality. "Thus, mention has been made in academic writing and by the Hellenic Republic in its observations, of the Community principle of sincere cooperation laid down by Article 10 EC, which could be affected if a Member State were to carry out, without consulting the Commission or its partners, an unjustified mass naturalisation of nationals of non-Member States" (emphasis added, GMG).

111 See Chapter 4, section 5.

112 Although the newly independent States are, from the outset, not legally bound by EU law. 
Chapter 5 examines the eventual retention by certain categories of people of some rights linked to the possession of Member State nationality and, therefore, to the citizenship of the Union, that are being exercised at the moment of independence, even if Catalonia, Flanders or Scotland found themselves outside of the EU. Following the thesis first developed by Vidmar, ${ }^{113}$ the chapter assesses the possible retention (or freezing) ${ }^{114}$ of residence rights in light of the ECHR and the doctrine developed by the ECtHR in the landmark case Kurić and others $v$ Slovenia. ${ }^{115}$ The similarities between the case at stake in the Kurić decision and a potential independence of Catalonia, Flanders or Scotland could allow establishing a strong link between the right to reside in a certain territory and the human right to private and family life as laid down in Article 8 ECHR. However, this protection has certain time and space limitations. Moreover, the way in which enjoying the right to remain in the territory of the newly independent State, the predecessor State or other EU Member State would depend on different factors. What role could EU citizenship status play in this this scenario?

The findings of this Chapter are also of paramount importance for British citizens residing in other EU Member States at the moment of coming into effect of the "Brexit" and for EU citizens residing in Britain in that very moment.

Chapter 6 draws together the conclusions of the research. This chapter highlights the legal difficulties inherent in a potential State succession scenario within an EU Member State. In answering the research questions, recommendations on how to address the effect of a State succession for the enjoyment of certain rights and freedoms are made. These recommendations take into account the different actors and the different legal systems that are called to play a role in such a scenario, acknowledging the limitations of the EU as an international organisation to tackle this situation from the perspective of Member States but highlighting the

113 Jure Vidmar, "The Scottish Independence Referendum in an International Context," Canadian Yearbook of International Law 51, 2013, pp. 259-288.

114 Note that Vidmar first uses the expression "freeze" and "freezing" when referring to the retention of residence rights in the context of the Scottish independence referendum, Jure Vidmar, "The Scottish Independence Referendum in an International Context," Canadian Yearbook of International Law 51, 2013, pp. 282 and 284.

115 Case Kurić and Others v Slovenia, Application No. 26828/06, 26 June 2012. See also Vidmar, who highlighted the relevance of the Kurić decision in the framework of the Scottish independence referendum in Jure Vidmar, "The Scottish Independence Referendum in an International Context," Canadian Yearbook of International Law 51, 2013, pp. 259-288. 
potential of the citizenship of the Union as a new factor to take into account in this situation. Due to the inherent legal nature of this research, the conclusions which are made are also of a legal nature.

\section{Concluding Remarks}

This first Chapter has provided a brief introduction to the main topic of the thesis. It has outlined the research questions and explained the scope and methodology which will be followed. The thesis aims to shed light on the legal consequences of a potential secession process within an EU Member State with regards to State's obligations within the scope of EU law and/or international and regional standards, as well as the individuals' enjoyment of rights and freedoms attached to European citizenship. Specifically, this thesis analyses the situation of nationals from the seceding regions who reside in the new States and in the territory of other EU Member States, and European citizens and third country nationals residing in the seceding territories. It would seem contradictory to address EU citizenship in the context of State succession given that this status has contributed significantly to the EU integration process. Nevertheless, a common theme amongst the independence waves in Catalonia, Flanders and Scotland is the desire to achieve that independence within the EU, born as an independent EU Member States from the outset. In line with this eagerness, it has been claimed that the status of citizen of the Union may allow a territory seceding from a Member State to remain in the Union after independence. This claim does not take into account, however, the fact that EU citizenship unavoidably relies on possessing the nationality of a Member State. Due to the existence of this link between citizenship of the Union and nationality of Member States, it is necessary to take a step back in order to determine, first, how nationality issues are settled in a State succession scenario; and second, how nationality matters can be influenced by EU law. Only then, is one correctly positioned to assess the consequences of State succession for the exercise of the rights flowing from citizenship of the Union.

Following this path, the thesis analyses different and intertwined legal orders. Thus Public International Law underpins the study of the State succession, right to self-determination, rules applicable to nationality matters arising in State succession and States membership of international organisations. This latter question is also assessed as a matter of EU law, together with the role of European citizenship and nationality law from the Member States that compromise the territorial scope of the research (Spain, Belgium and the United Kingdom). Nationality law falls under the auspices of domestic law, as are the practices regarding the attribution of nationality upon decolonisation. As explained, nationality matters fall within the domaine réservé of the States but both Public International Law 
and European Law curtail this sovereign prerogative. Nationality is also a concept of both international and domestic law, which provides the basis to enjoy the status of citizen of the Union.

Although the concept of nationality has evolved from ancient Rome, the current conceptions of nationality, the ancient concept of the civis and even the concept of citizen of the Union still share one common feature: that is the enjoyment of a certain set of rights. The sentence "civis romanus sum" was used as a plea for the legal rights of Romans citizens, as reflected by Cicero in In Verrem. ${ }^{116}$ Even St. Paul the Apostle invoked his status as "Roman citizen" when imprisoned:

"They beat us publicly without a trial, even though we are Roman citizens, and threw us into prison. And now do they want to get rid of us quietly? No! Let them come themselves and escort us out. The officers reported this to the magistrates, and when they heard that Paul and Silas were Roman citizens, they were alarmed. They came to appease them and escorted them from the prison". ${ }^{117}$

Nowadays, nationals of Member States can plea for the rights attached to EU citizenship status. But could nationals of a newly created State, as a consequence of a State succession from a Member State, invoke "civis europaeus sum"? 118

116 Marcus Tullius Cicero, Against Verres (In Verrem), part 2, book 5, section 147. "His institutis cum completus iam mercatorum carcer esset, tum illa fiebant quae Lucium Suettium, equitem romanum, lectissimum virum, dicere audistis, et quae ceteros audietis. Cervices in carcere frangebantur indignissime civium romanorum, ut iam illa vox et imploratio, "civis romanus sum", quae saepe multis in ultimis terris opem inter barbaros et salutem tulit, ea mortem illis acerbiorem et supplicium maturius ferret".

117 Acts, 16:37-39.

118 On the importance of the statement "civis europaeus sum" also (albeit from a different perspective), see Koen Lenaerts, "'Civis europaeus sum': from the crossborder link to the status of citizen of the Union" Online Journal on free movement of workers within the European Union, No. 3, Luxemburg, 2011 and Liesbeth A Campo, Shaping the concept of European Union Citizenship: Civis Europeus sum?, Masther thesis, Maastricht University, 2012. 


\section{Chapter 2: State Succession and Nationality in International Law}

\section{State Succession: General Overview}

\subsection{Brief Notes on Statehood}

Writing about the phenomenon of State succession involves touching upon a key topic of international law, i.e., the creation of States. Until 1914, secession was the most common method for the creation of new States. The period from 1776 to 1900 saw, inter alia, the American War of Independence, the revolutions of the former Spanish colonies in South and Central America, the secession of Greece from the Ottoman Empire and the secession of Belgium from the Netherlands. Since 1919, new States have been more often than not been created with the consent of their former sovereign, especially in the course of decolonisation. ${ }^{119}$ Despite the changes that have occurred in international society such as the emergence and proliferation of international organisations and the claims that the concept of State is weakened, ${ }^{120}$ international law remains focused and supported by the figure of the State as a political and social entity. ${ }^{121}$ As

119 For a brief overview on the creation of new States during decolonisation process see footnote 1, Chapter 1 . Before the World War II there were around seventy-five States. Nowadays, according to the membership list of the UN, there are 193 States. See James Crawford, The Creation of States in International Law, 2nd edition, Oxford Scholarship Online, Oxford, 2007 (2nd edition), p. 4.

120 Paz Andrés Sáenz de Santa María, Sistema de Derecho Internacional Público, Aranzadi, Navarra ( $3^{\text {rd }}$ edition), p. 57; James Crawford, The Creation of States in International Law, Oxford Scholarship Online, Oxford, 2007 (2nd edition); Malcolm D. Evans, International Law, Oxford University Press, Oxford, 2010 (3rd edition), pp. 206-208; Antonio F. Fernández Tomas, Ángel Sánchez Legido, Juan Miguel Ortega Terol, Ignacio Forcada Barona, Lecciones de Derecho Internacional Público, Tirant lo Blanch, Valencia, 2011, p. 39; Antonio Fernández Tomás, Ángel Sánchez Legido, Juan Miguel Ortega Terol, Manual de Derecho Internacional Público, Tirant lo Blanch, Valencia, 2004, p. 127; Wilhelm G. Grewe, The Epochs of International Law, Walter de Gruyter, Berlin-NewYork, 2000, pp. 706-710; Antonio Remiro Brotóns, Rosa Riquelme Cortado, Esperanza Orihuela Calatayud, Javier Díez-Hochleitner, Luis Pérez-Prat Durban, Derecho Internacional. Curso general, Tirant lo Blanch, Valencia, 2010, p. 68.

121 Paz Andrés Sáenz de Santa María, Sistema de Derecho Internacional Público, Aranzadi, Navarra ( $3^{\text {rd }}$ edition), p. 57; Antonio Cassese, International Law, Oxford University Press, New York, 2005 ( $2^{\text {nd }}$ edition), pp. 71-72; Andrew Clapham, Brierly's Law of Nations, Oxford University Press, Oxford, 2012, pp. 139-142; Manuel Diez de 
a matter of fact, Catalonia, Flanders and Scotland's claims for Statehood reflect the supremacy of the State as the main subject in international law. ${ }^{122}$

Essentially, the creation of States is still considered as a pre-legal and political issue; a fact that international law takes into account and attributes a certain legal status. ${ }^{123}$ International law does not regulate,

Velasco, Instituciones de Derecho Internacional Público, Tecnos, Madrid, 2013 (18 ${ }^{\text {th }}$ edition), p. 258; Antonio Fernández Tomás, Ángel Sánchez Legido, Juan Miguel Ortega Terol, Manual de Derecho Internacional Público, Tirant lo Blanch, Valencia, 2004, p. 128; Julio D. González Campos, Luis I. Sánchez Rodríguez, Paz Andrés Sáenz de Santa María, Curso de Derecho Internacional Público, Aranzadi, Navarra, 2008 ( $4^{\text {th }}$ edition revised), p. 119; Antonio Remiro Brotóns, Rosa Riquelme Cortado, Esperanza Orihuela Calatayud, Javier Díez-Hochleitner, Luis Pérez-Prat Durban, Derecho Internacional. Curso general, Tirant lo Blanch, Valencia, 2010, p. 67; Malcom N. Shaw, International Law, Cambridge University Press, Cambridge, 2014 ( $7^{\text {th }}$ edition), p. 143; Rebecca M. M. Wallace, International Law, Sweet and Maxwell, London, 2005 (5th edition), pp. 60-61.

122 Paz Andrés Sáenz de Santa María, Sistema de Derecho Internacional Público, Aranzadi, Navarra (3rd edition), pp. 57-58; Ian Brownlie, Principles of Public International Law, Clarendon Press, Oxford, 1990 (4 ${ }^{\text {th }}$ edition), pp. 58-61; Oriol Casanovas, Ángel J. Rodrigo, Compendio de Derecho Internacional Público, Tecnos, Madrid, 2014 (3rd edition), p. 145; Antonio Cassese, International Law, Oxford University Press, New York, 2005 ( $2^{\text {nd }}$ edition), pp. 71-72; Martin Dixon, Robert McCorquodale and Sarah Williams, Cases and Materials on International Law, Oxford University Press, Oxford, 2011 ( $5^{\text {th }}$ edition), pp. 133-138; Antonio F. Fernández Tomas, Ángel Sánchez Legido, Juan Miguel Ortega Terol, Ignacio Forcada Barona, Lecciones de Derecho Internacional Público, Tirant lo Blanch, 2011, Valencia, pp. 39-41; Julio D. González Campos, Luis I. Sánchez Rodríguez, Paz Andrés Sáenz de Santa María, Curso de Derecho Internacional Público, Navarra, 2008, pp. 119-120; Carlos Jiménez Piernas, Introducción al Derecho Internacional Público. Práctica de España y de la Unión Europea, Tecnos, Madrid, 2011, p. 171; José A. Pastor Ridruejo, Curso de Derecho Internacional Público y Organizaciones Internacionales, Tecnos, $19^{\text {th }}$ edition, Madrid, p. 299; Alejandro J. Rodríguez Carrión, Lecciones de Derecho Internacional Público, Tecnos, $6^{\text {th }}$ edition, Madrid, 2006, pp. 70-71; Malcom N. Shaw, International Law, Cambridge University Press, Cambridge, 2014 (7th edition), p. 143; Rebecca M. M. Wallace, International Law, Sweet and Maxwell, London, 2005 (5th edition), p. 60.

123 Manuel Diez de Velasco, Instituciones de Derecho Internacional Público, Tecnos, Madrid, 2013 (18th edition), p. 5; Malcom N. Shaw, International Law, Cambridge University Press, Cambridge, 2014 (7th edition), p. 144. See the Opinion No. 1 of the Arbitration Commission of the European Conference on Yugoslavia (Badinter Commission) which provides that "the principles of public international law (...) serve to define the conditions on which an entity constitutes a state; (...) in this respect, the existence or disappearance of the state is a question of fact", Alain Pellet, The Opinions of the Badinter Arbitration Committee A Second Breath for the SelfDetermination of Peoples, European Journal of International Law , 3 (1), 1992, p. 182. In the same vein see Lassa Oppenheim and Ronald Roxburg stating that "The 
per se, the processes that lead to the creation of States. ${ }^{124}$ This does not, however, imply that international law completely ignores the processes that lead to the creation of States, since there are international legal rules pertaining to this issue. Indeed, the Statehood criteria have been codified, inspired by Jellinek's approach, ${ }^{125}$ by the Montevideo Convention on the Rights and Duties of States. ${ }^{126}$ According to Article 1 of this Convention, a State exists when the following criteria are met: a permanent population; a defined territory; government; and the capacity to enter into relations with the other States. ${ }^{127}$

In more contemporary literature, additional Statehood criteria have been developed. As noted by Vidmar, these additional criteria do not emerge in

formation of a new State is (...) a matter of fact, and not of law" Lassa Oppenheim and Ronald Roxburg, International Law: A Treatise, Longmans, vol. 1, London, 1920, p. 373. See also Oriol Casanovas, Ángel J. Rodrigo, Compendio de Derecho Internacional Público, Tecnos, Madrid, 2014 (3rd edition), p. 161; Antonio Cassese, International Law, Oxford University Press, New York, 2005 ( $2^{\text {nd }}$ edition), pp. 7273; Manuel Diez de Velasco, Instituciones de Derecho Internacional Público, Tecnos, Madrid, 2013, $18^{\text {th }}$ edition, p. 285; Malcolm D. Evans, International Law, Oxford University Press, Oxford, 2010 (3rd edition), pp. 217-221; Antonio F. Fernández Tomas, Ángel Sánchez Legido, Juan Miguel Ortega Terol, Ignacio Forcada Barona, Lecciones de Derecho Internacional Público, Tirant lo Blanch, 2011, Valencia, p. 63; Carlos Jiménez Piernas, Introducción al Derecho Internacional Público. Práctica de España y de la Unión Europea, Tecnos, Madrid, 2011, p. 171.

124 Paz Andrés Sáenz de Santa María, Sistema de Derecho Internacional Público, Aranzadi, Navarra (3rd edition), p. 58; Julio D. González Campos, Luis I. Sánchez Rodríguez, Paz Andrés Sáenz de Santa María, Curso de Derecho Internacional Público, Aranzadi, Navarra, 2008 (4th edition revised), p. 467. See on the "a-legal" character of secession Harry Beran, "A Liberal Theory of Secession", 32 Political Studies, 1984, pp. 21-31; Allen Buchanan, Secession: The Morality of Political Divorce from Fort Sumpter to Lithuania and Québec, Westview Press, Boulder, 1991; Christopher Heath Wellman, A Theory of Succession: The Case for Political Self-determination, Cambridge University Press, Cambridge, 2005.

125 George Jellinek and Walter Jellinek, Allgemeine Staatslehre, Julius Springer, Berlin, 1929 ( $3^{\text {rd }}$ edition), pp. 179-183 and 394-434. According to Jellinek, a State must have the following elements: a territory, a population and a public authority.

126 Montevideo Convention on the Rights and Duties of States (Montevideo, 26 December 1933) 165 LNTS 19.

127 In the same vein, Opinion No. 1 of the Arbitration Commission of the European Conference on Yugoslavia provides that "the state is commonly defined as a community which consists of a territory and a population subject to an organized political authority; that such a state is characterized by sovereignty", Alain Pellet, "The Opinions of the Badinter Arbitration Committee A Second Breath for the SelfDetermination of Peoples", European Journal of International Law, 3 (1), 1992, p. 182. For a more detailed description of the origin of the Montevideo criteria, see Thomas D. Grant, The Recognition of States: Law and Practice in Debate and Evolution, Greenwood Publishing Group, Westport, 1999, pp. 6-9. 
the law of Statehood but in other fields of international law and are rooted in the prohibition of aggression, the prohibition of racial discrimination and the right to self-determination. ${ }^{128}$ There is a general philosophy underpinning these criteria, i.e. an entity that meets the Montevideo criteria but has been created in violation of certain legal standards cannot be a State. ${ }^{129}$ Thus, "entities which would have otherwise qualified as a State may not do so because their creation is substantially illegitimate". ${ }^{130}$

Nevertheless, "[r]ecourse to the statehood criteria, both traditional and additional, is thus not sufficient to determine whether or not an entity is a State". ${ }^{131}$ A paradigmatic example of an entity that meets both the traditional and the additional Statehood criteria, but is not considered a State, is Somaliland. The Republic of Somaliland meets the Statehood criteria and its emergence as a consequence of the dissolution of the Republic of Somalia did not violate any international norms, especially the prohibition of the use of the force. ${ }^{132}$ However, no State has hitherto recognised the independence of Somaliland. ${ }^{133}$

In this sense, the principle of territorial integrity plays a leading role, becoming an important limitation for the emergence of new States. ${ }^{134}$

128 Jure Vidmar, "Territorial Integrity and the Law of Statehood", George Washington International Law Review, Vol. 44, 2013, p. 704.

129 Thus, the illegal use of force (Northern Cyprus), the violation of the right of selfdetermination (Southern Rhodesia) and the racial discrimination (South African Homelands) led to an illegal creation of States, even if the entity meets the traditional Montevideo statehood criteria, Jure Vidmar, "Territorial Integrity and the Law of Statehood", George Washington International Law Review, Vol. 44, 2013, p. 704.

130 James Crawford, The Creation of States in International Law, Oxford Scholarship Online, Oxford, 2007 (2nd edition), p. 439.

131 Jure Vidmar, "Territorial Integrity and the Law of Statehood", George Washington International Law Review, Vol. 44, 2013, p. 706.

132 Farley asserts that "Somaliland meets the objective criteria of statehood and its separation from Somalia represents the dissolution of a state in conformity with international norms". Benjamin R. Farley, "Calling a State a State: Somaliland and International Recognition", Emory International Law Review, Vol. 24, No. 2, 2010, pp. 777 and 815-818. See also Jure Vidmar, "Territorial Integrity and the Law of Statehood", George Washington International Law Review, Vol. 44, 2013, p. 706.

133 James Crawford, The Creation of States in International Law, Oxford Scholarship Online, Oxford, 2007 (2nd edition), pp. 413-415. See also Benjamin R. Farley, "Calling a State a State: Somaliland and International Recognition", Emory International Law Review, Vol. 24, No. 2, 2010, pp. 809-815; and Jure Vidmar, "Territorial Integrity and the Law of Statehood", George Washington International Law Review, Vol. 44, 2013, p. 706.

134 Vidmar states that "In this era it [referring to the principle of territorial integrity of States, GMG] appears to be the most challenging hurdle an entity needs to 
Article 2(4) of the UN Charter ${ }^{135}$ refers to this principle in relation to the prohibition of the use of force:

"All Members shall refrain in their international relations from the threat or use of force against the territorial integrity or political independence of any state (...)".

The Declaration on Principles of International Law ${ }^{136}$ provides for the following limitation not only in the relations between States, but also with regard to the people's right of self-determination: ${ }^{137}$

"Nothing in the foregoing paragraphs [referring to the right of selfdetermination] shall be construed as authorizing or encouraging any action which would dismember or impair, totally or in part, the territorial integrity or political unity of sovereign and independent States conducting themselves in compliance with the principle of equal rights and self- determination of peoples as described above and thus possessed of a government representing the whole people belonging to the territory without distinction as to race, creed or colour".

Thus, one can concur with Vidmar that

"(...) nearly all territories form an integral part of a sovereign State and are protected by the principle of territorial integrity. The principle of territorial integrity does not prevent the emergence of new States, but it does ensure that the new States do not emerge automatically once they satisfy the statehood criteria".138

\subsection{State Succession.}

As a starting point, this chapter will describe the phenomenon of State succession, based on Article 2 of the two Vienna Conventions on State succession: the 1978 Vienna Convention on the Succession of States in

overcome on its path to statehood". Jure Vidmar, "Territorial Integrity and the Law of Statehood", George Washington International Law Review, Vol. 44, 2013, p. 707.

135 Charter of the United Nations, 24 October 1945, 1 UNTS XVI.

136 Declaration on Principles of International Law concerning Friendly Relations and Cooperation among States in accordance with the Charter of the United Nations, 24 October 1970, A/RES/2625(XXV).

137 Jure Vidmar, "Territorial Integrity and the Law of Statehood", George Washington International Law Review, Vol. 44, 2013, pp. 707-708

138 Jure Vidmar, "Territorial Integrity and the Law of Statehood", George Washington International Law Review, Vol. 44, 2013, p. 700. 
Respect of Treaties ${ }^{139}$ and the 1983 Vienna Convention on the Succession of States in Respect of Property Archives and Debts. ${ }^{140141}$ The definition of State succession as established in those conventions reads as follows:

"Succession of States means the replacement of one State by another in the responsibility for the international relations of territory". ${ }^{142}$

Article 3 of the two Vienna Conventions on State succession stipulates that they only apply to State successions which take place in conformity with international law, in particular with the principles of international law embodied in the UN Charter.

This definition envisages four main categories of State succession:

1. Succession in respect of part of territory. According to Article 15 of the 1978 Vienna Convention, this category covers the scenario when part of the territory of a State becomes part of the territory of another State. Also falling under this general category is the transfer of part of the territory of a State, i.e., the situation where a dependent territory becomes part of the territory of a State other than the State which was previously responsible for its international relations. The 1983 Vienna Convention refers expressly to that category, "transfer of part of the territory of a State", in Article 14. Similarly, the ILC Draft Articles on

139 Vienna Convention on Succession of States in respect of Treaties, 23 August 1978 (Registered ex officio on 6 November 1996), UNTS, 1946, p. 33356.

140 Vienna Convention on the Succession of States in Respect of Property, Archives and Debts, 8 April 1983, UN Juridical Yearbook, 1983 (Sales No. E.90.V.1), p. 139.

141 The Conventions have attracted only a very small number of ratifications. The 1978 Convention entered into force in 1996 and has 22 parties while the 1983 Convention has not yet entered in to force. Only seven States have signed the 1983 Convention. According to Article 50 of the Convention, it shall enter into force "on the thirtieth day following the date of deposit of the fifteenth instrument of ratification or accession".

142 Compare the remarks on the concept of State Succession by the International Law Commission: "The Commission considered that the expression in the responsibility for the international relations of territory is preferable to other expressions such as in the sovereignty in respect of territory or in the treatymaking competence in respect of territory, because it is a formula commonly used in State practice and more appropriate to cover in a neutral manner any specific case independently of the particular status of the territory in question (national territory, trusteeship, mandate, protectorate, dependent territory, etc.). The word responsibility should be read in conjunction with the words for the international relations of territory and does not intend to convey any notion of State responsibility, a topic currently under study by the Commission and in respect of which a general reservation has been inserted in article 38 of the present draft" (Yearbook of the International Law Commission, 1974, vol. II, Part One, p. 175). 
nationality of natural persons in relation to the succession of States ${ }^{143}$ devotes Part II of its provisions to specific categories of succession of States, the first category being the "transfer of part of the territory".

2. Unification of States. This is defined as when two or more States unite and thereby form one successor State. This category is given further specification in Article 16 of the 1978 Vienna Convention, and can also be found in Article 31 of the 1983 Vienna Convention and Article 21 of the ILC Draft Articles.

3. Separation of part(s) of a State. Article 17 of the 1978 Vienna Convention defines this category of State succession in the following way: "when a part or parts of the territory of a State separate to form one or more States, whether or not the predecessor State continues to exist". ${ }^{144} \mathrm{~A}$ similar wording is found in Article 30 of the 1983 Vienna Convention ("when part or parts of the territory of a State separate from that State and form a State") and Article 24 of the ILC Draft Articles ("when part or parts of the territory of a State separate from that State and form one or more successor States").

4. Dissolution of a State. This category of State succession takes place when a State "dissolves and ceases to exist and the parts of the territory of the predecessor State form two or more successor States". ${ }^{145}$ The dissolution of a State, as a category of State succession, is mentioned in the 1983 Vienna Convention and the ILC Draft Articles (Article 22), but finds no place in the 1978 Vienna Convention. However, this category was not ignored by the drafters of the 1978 Vienna Convention. In the 1974 Report of the ILC to the General Assembly, ${ }^{146}$ the Commission questioned whether there was enough distinction between the dissolution of a State and the separation of part of a State to justify treating the former as a category in its own right. Although in previous draft versions there was a provision entitled "Dissolution of a State", ${ }^{147}$

143 International Law Commission, Articles on Nationality of Natural Persons in Relation to the Succession of States (With Commentaries), 3 April 1999, Supplement No. 10 (A/54/10).

144 Vienna Convention on Succession of States in respect of Treaties, 23 August 1978 (Registered ex officio on 6 November 1996), UNTS, 1946, p. 33356, Article 34.

145 Vienna Convention on the Succession of States in Respect of Property Archives and Debts, 8 April 1983, UN Juridical Yearbook, 1983 (Sales No. E.90.V.1), p. 139, Article 31.

146 Draft Articles on Succession of States in respect of Treaties with commentaries, Report of the Commission to the General Assembly, Yearbook of the International Law Commisssion, 1974, Vol. II, Part One, pp. 174-269.

147 Commentary on Articles 33 and 34, Draft Articles on Succession of States in respect of Treaties with commentaries, Report of the Commission to the General Assembly, 
the Commission ultimately decided to re-arrange the provisions dealing with dissolution and separation, resulting in what is currently Article 34. As already stated, that provision deals with the category of separation of parts of a State but it is worded in such a way so as to include both situations. ${ }^{148}$ Article 34 therefore reads as follows: "when a part or parts of the territory of a State separate to form one or more States, whether or not the predecessor State continues to exist". Thus, the last sentence of that provision acknowledges the possible dissolution of the predecessor State. ${ }^{149}$

Whilst these categories of State succession are useful in assessing the consequences of State succession in a particular scenario, it is by no means an exhaustive list. Some scholars have developed other classifications that include categories such as annexation, merger and cession and more general categories such as universal succession and partial succession. ${ }^{150}$ Furthermore, practice has also shown how difficult is to apply a certain theoretical category to a specific case of State succession. ${ }^{151}$ For instance, the German reunification in 1990 can be seen as a case of unification of State, that is, when two or more States unite and so form one successor State. However, strictly speaking, it was the German Democratic Republic that joined the Federal Republic of Germany. ${ }^{152}$ As has already been mentioned vis-a-vis dissolution, even the ILC, during the drafting process of the two Vienna Conventions, had difficulty in differentiating between the two categories.

Yearbook of the International Law Commisssion, 1974, Vol. II, Part One, p. 264.

148 Commentary on Articles 33 and 34, Draft Articles on Succession of States in respect of Treaties with commentaries, Report of the Commission to the General Assembly, Yearbook of the International Law Commisssion, 1974, Vol. II, Part One, p. 266.

149 According to the report, this provision deals with the case where part or parts of the territory of a State separate to form one or more States, whether or not the predecessor State continues to exist, "that is to say, whether or not it is dissolved". See Commentary on Articles 33 and 34, Draft Articles on Succession of States in respect of Treaties with commentaries, Report of the Commission to the General Assembly, Yearbook of the International Law Commisssion, 1974, Vol. II, Part One, p. 266

150 Gerhard von Glahn and James Larry Taulbee, Law Among Nations, Pearson Longman, New York, 2007 (8 $8^{\text {th }}$ edition), pp. 196-201.

151 Ian Brownlie, Principles of Public International Law, Clarendon Press, Oxford, 1990 ( $4^{\text {th }}$ edition), p. 655. See also Rudolf Graupner, "Nationality and State Succession: General Principles of the Effect of Territorial Changes on Individuals in International Law", Transactions of the Grotius Society Vol. 32, 1946, pp. 96-119.

152 See Vertrag zwischen der Bundesrepublik Deutschland und der Deutschen Demokratischen Republik über die Herstellung der Einheit Deutschlands (Einigungsvertrag), 31 August 1990, BGBl. 1990 II S. 889. 
Hereinafter, this thesis will adopt the definitions of predecessor State and successor State as provided for in the two Vienna Conventions. While the predecessor State is understood as one that is replaced by another following a State succession, the successor State is understood as the one that comes to replace the previous. The predecessor State, in the process of State succession, can disappear or continue to exist, preserving in that case the legal status of the existing State, although limited geographically.

In this context it follows that another concept must be taken into account, i.e. the continuing State. A continuing State is the State which is regarded as having the same international legal personality as the predecessor State despite a change in circumstances, e.g. a loss of territory or population. In the words of Crawford and Boyle State continuity denotes

"cases where the same state continues to exist despite changes in its territory and population. The central case of continuity is where a state retains substantially the same territory and the same structure or system of government over a certain period". ${ }^{153}$

The concept of the continuing State is one which is of paramount importance in relation to the issue of membership of international organisations. This analysis will be given further elaboration in section 3 of this Chapter.

\section{Self-Determination}

Independence proponents in Catalonia, Flanders and Scotland often cite self-determination as one of the main arguments in support of the independence of their region. ${ }^{154155}$ Article 1 of the UN Charter identifies the development of "friendly relations among nations based on respect for the principle of equal rights and self-determination of peoples" as one of the UN's primary purposes. ${ }^{156}$ Similarly, both Article 1 of the International Covenant

153 James Crawford and Alan Boyle, Annex A-Opinion: Referendum on the Independence of Scotland-International Law Aspects, Scotland Analysis: Devolution and the Implications of Scottish Independence, United Kingdom Government, 2013, p. 71.

154 See Chapter 3, sections 1, 2 and 3.

155 On the historical background of the right to self-determination see: David Raič, Statehood and the Law of Self-Determination, Kluwer Law International, The Hague - London - New York, 2002, pp. 171-305. See also Oriol Casanovas, Ángel J. Rodrigo, Compendio de Derecho Internacional Público, Tecnos, Madrid, 2014 (3rd edition), p. 39.

156 United Nations, Charter of the United Nations, 24 October 1945, 1 UNTS XVI, Article 1, para. 2. 
on Civil and Political Rights (ICCPR) ${ }^{157}$ and Article 1 of the International Covenant on Economic, Social and Cultural Rights (ICESCR) ${ }^{158}$ establish that:

"all peoples have the right of self-determination. By virtue of that right they freely determine their political status and freely pursue their economic, social and cultural development."

Notwithstanding the general wording of the aforementioned provisions, self-determination has become almost exclusively associated with the decolonisation process. Indeed, it has been argued that self-determination only amounts to a right of "external self-determination", that is to say, a right to independent Statehood only exists for overseas colonies, such as the former European possessions in Africa, America and Asia. ${ }^{159}$

The UN General Assembly first proclaimed the right of colonies to external self-determination in the 1960 Declaration on the Granting of Independence to Colonial Countries and Peoples. ${ }^{160}$ This General Assembly Resolution proclaims:

"the necessity of bringing to a speedy and unconditional end colonialism in all its forms and manifestations".

The International Court of Justice (ICJ) has furthermore held that the right to external self-determination in the colonial context has achieved the status of customary international law. ${ }^{161}$ Moreover, external selfdetermination within the context of the decolonisation process was consistent with the principles of territorial integrity and sovereignty, since -with few exceptions- overseas colonies were not considered integral parts of the European States that governed them, and their loss did not

157 International Covenant on Civil and Political Rights, 16 December 1966, UNTS, 999 , p. 171.

158 International Covenant on Economic, Social and Cultural Rights, 16 December 1966, UNTS, Treaty Series, 993, p. 3.

159 David Raič, Statehood and the Law of Self-Determination, Kluwer Law International, The Hague - London - New York, 2002, pp. 226-227. See also Jure Vidmar, "Remedial Secession in International Law: Theory and (Lack of) Practice", St Anthony's International Review, No. 1, 2010, pp. 37-38.

160 UN General Assembly, Declaration on the Granting of Independence to Colonial Countries and Peoples, 14 December 1960, A/RES/1514(XV). In this resolution the General Assembly proclaims "the necessity of bringing to a speedy and unconditional end of colonialism in all its forms and manifestations".

161 Western Sahara, Advisory Opinion, ICJ GL No 61, [1975] ICJ Rep 12, ICGJ 214 (ICJ 1975), 16th October 1975, International Court of Justice. See on the Advisory Opinion on Western Sahara section 6.1.3 of this Chapter. 
therefore threaten the sovereignty or alter the borders of the parent State. ${ }^{162}$

There is little support, however, for the proposition that a right to external self-determination exists outwith the colonial context. One must remember that international law is, first and foremost, a set of rules made by States, for States. Therefore, the reluctance of States to support a right that would justify their own dismemberment will come as no surprise. However, some authors ${ }^{163}$ support the existence of a right to external self-determination outside the colonial context by application of the so-called "remedial secession" theory. ${ }^{164}$ The remedial secession theory can be understood as a solution of last resorts whereby a particular group within the territory of an existing State is denied basic democratic freedoms and is subjected to severe human rights abuses. ${ }^{165}$

The international community is far from accepting of such remedial secession. By way of example, Kosovo, whose population suffered severe human rights abuses by Serbia, was perhaps (in Europe at least) the most salient and recent example of a situation whereby remedial secession could apply. The ICJ, in a 2010 Advisory Opinion on the legality of Kosovo's secession from Serbia, eschewed discussion on the issue of remedial secession altogether. ${ }^{166}$ Accordingly, while acknowledging the "radically different views" on whether a right to remedial secession exists, the court determined that "it is not necessary to resolve these questions in the present case". By avoiding the issue, the ICJ's opinion cast doubt on the viability of non-colonial external self-determination claims.

162 Christopher K. Connolly, Independence in Europe: Secession, Sovereignty, and the European Union, 24 Duke Journal of Comparative \& International Law 51-105 (2013), p. 68.

163 Jure Vidmar, "Remedial Secession in International Law: Theory and (Lack of) Practice", St Anthony's International Review, No. 1, 2010, p. 40, with further references to authors supporting this idea. See also Simone F. van den Driest, Remedial Secession: A right to External Self-determination and Secession, Intersentia, Antwerp-Oxford-Portland, 2013.

164 The concept of remedial secession finds support in the League of Nations reports on the Aaland Islands and, more recently, in the UN General Assembly's 1970 Declaration Concerning Friendly Relations and Co-operation among States. See Jure Vidmar, "Remedial Secession in International Law: Theory and (Lack of) Practice", St Anthony's International Review, No. 1, 2010, p. 40.

165 Jure Vidmar, "Remedial Secession in International Law: Theory and (Lack of) Practice", St Anthony's International Review, No. 1, 2010, p. 40.

166 Accordance with International Law of the Unilateral Declaration of Independence in Respect of Kosovo (Request for Advisory Opinion), General List No. 141, International Court of Justice (ICJ), 22 July 2010. 
Thus, when a particular group within a State claims a right to selfdetermination the strongest right which they can rely on is "internal selfdetermination", which may be understood as basic human and democratic rights coupled with certain minority rights that are designed to recognise and protect the particular groups' culture and identity. ${ }^{167}$

In 1998 the Canadian Supreme Court reaffirmed international law's preference for internal self-determination. In the Advisory Opinion on the Secession of Quebec issued at the request of the Canadian Government, the court examined whether Quebec possessed a unilateral right to secede under either domestic or international law. ${ }^{168}$ After finding that Canadian domestic law did not support a right to unilateral secession, the court explained that under international law,

"the right to self-determination of a people is normally fulfilled through internal self-determination - a people's pursuit of its political, economic, social and cultural development within the framework of an existing state. A right to external self-determination (which in this case potentially takes the form of the assertion of a right to unilateral secession) arises in only the most extreme of cases and, even then, under carefully defined circumstances". ${ }^{169}$

What is remarkable are the comments made by the court on the process of negotiated secession within the Canadian constitutional framework. According to the court, while Canadian domestic law does not foresee the unilateral secession of one of its provinces, the Constitution "is not a straightjacket"; thus

"a clear majority vote in Quebec on a clear question in favour of secession would confer democratic legitimacy on the secession initiative which all of the other participants in Confederation would have to recognize". ${ }^{170}$

In this sense, the Court elaborates on the existence of a sort of quasiobligation to negotiate within the Canadian constitutional framework, as follows:

167 Christopher K. Connolly, Independence in Europe: Secession, Sovereignty, and the European Union, 24 Duke Journal of Comparative \& International Law 51-105 (2013), p. 73.

168 Reference re Secession of Quebec, [1998] 2 S.C.R. 217. For further commentary on this decision, see: David Haljan, Constitutionalising Secession, Hart Publishing, Oxford and Portland, 2014.

169 Reference re Secession of Quebec, [1998] 2 S.C.R. 217, para. 82.

170 Reference re Secession of Quebec, [1998] 2 S.C.R. 217, para. 150. 
"The federalism principle, in conjunction with the democratic principle, dictates that the clear repudiation of the existing constitutional order and the clear expression of the desire to pursue secession by the population of a province would give rise to a reciprocal obligation on all parties to Confederation to negotiate constitutional changes to respond to that desire. The amendment of the Constitution begins with a political process undertaken pursuant to the Constitution itself. In Canada, the initiative for constitutional amendment is the responsibility of democratically elected representatives of the participants in Confederation. Those representatives may, of course, take their cue from a referendum, but in legal terms, constitution-making in Canada, as in many countries, is undertaken by the democratically elected representatives of the people. The corollary of a legitimate attempt by one participant in Confederation to seek an amendment to the Constitution is an obligation on all parties to come to the negotiating table. The clear repudiation by the people of Quebec of the existing constitutional order would confer legitimacy on demands for secession, and place an obligation on the other provinces and the federal government to acknowledge and respect that expression of democratic will by entering into negotiations and conducting them in accordance with the underlying constitutional principles already discussed". ${ }^{171}$

In light of that decision the Canadian Government passed the Clarity Act $2000,{ }^{172}$ which obliged Canada to negotiate with Quebec over the terms of a possible separation only following a referendum that would envisage a binary choice between either full separation or continued inclusion within the Canadian State. Accordingly, the Clarity Act 2000 prohibited any "referendum question that envisages other possibilities in addition to the secession of the province from Canada". ${ }^{173}$ The aim of this provision was to foreclose a referendum on "sovereignty association", a somewhat nebulous proposal often made by Quebecois nationalists under which Quebec, though nominally independent, would retain some form of political and economic partnership with the rest of Canada. ${ }^{174}$ According to this Act, in considering the clarity of a referendum question, it was remarked that,

171 Reference re Secession of Quebec, [1998] 2 S.C.R. 217, para. 88.

172 An Act to give effect to the requirement for clarity as set out in the opinion of the Supreme Court of Canada in the Quebec Secession Reference, S.C. 2000, c. 26, assented to 2000-06-29, availaible at http://laws.justice.gc.ca/eng/acts/C-31.8/ FullText.html.

173 An Act to give effect to the requirement for clarity as set out in the opinion of the Supreme Court of Canada in the Quebec Secession Reference, S.C. 2000, c. 26, assented to 2000-06-29, Article 1(4) b.

174 Christopher K. Connolly, "Independence in Europe: Secession, Sovereignty, and the European Union”, Duke Journal of Comparative \& International Law, Vol. 24, 2013. 
"the House of Commons shall consider whether the question would result in a clear expression of the will of the population of a province on whether the province should cease to be part of Canada and become an independent state". ${ }^{175}$

Regarding the concept of a clear majority, which was discussed although not fully developed in the analysis by the Supreme Court of Canada, the Clarity Act 2000 did not establish a certain numeric threshold to be reached or a qualified majority. The Clarity Act 2000 merely referred to factors to be taken into account by the House of Commons, such as:

"(a) the size of the majority of valid votes cast in favour of the secessionist option;

(b) the percentage of eligible voters voting in the referendum; and

(c) any other matters or circumstances it considers to be relevant". ${ }^{176}$

The Supreme Court of Canada's analysis on the right to self-determination has had significant implications for Catalonia, Flanders and Scotland. Some similarities can be drawn between the situation in these three regions where independence is being discussed and the case of Quebec. Neither

175 An Act to give effect to the requirement for clarity as set out in the opinion of the Supreme Court of Canada in the Quebec Secession Reference, S.C. 2000, c. 26, assented to 2000-06-29, Article 1(3). Furthermore, when considering the clarity of the referendum question, "the House of Commons shall take into account the views of all political parties represented in the legislative assembly of the province whose government is proposing the referendum on secession, any formal statements or resolutions by the government or legislative assembly of any province or territory of Canada, any formal statements or resolutions by the Senate, any formal statements or resolutions by the representatives of the Aboriginal peoples of Canada, especially those in the province whose government is proposing the referendum on secession, and any other views it considers to be relevant".

176 An Act to give effect to the requirement for clarity as set out in the opinion of the Supreme Court of Canada in the Quebec Secession Reference, S.C. 2000, c. 26, assented to 2000-06-29, Article 2(2). Furthermore, when considering whether there has been a clear political expression by a clear majority of the population of a province shall the province cease to be part of Canada, "the House of Commons shall take into account the views of all political parties represented in the legislative assembly of the province whose government proposed the referendum on secession, any formal statements or resolutions by the government or legislative assembly of any province or territory of Canada, any formal statements or resolutions by the Senate, any formal statements or resolutions by the representatives of the Aboriginal peoples of Canada, especially those in the province whose government proposed the referendum on secession, and any other views it considers to be relevant". 
the Canadian Constitution ${ }^{177}$ nor the Spanish or Belgian constitutions allow for the separation of an integral part of its territory. ${ }^{178}$ Indeed, the Spanish Constitution not only expressly asserts the existence of a single and indissoluble nation ${ }^{179}$ but it also stipulates that referendums may only be initiated by the national government. ${ }^{180}$

Vis-à-vis the United Kingdom, the 1707 Treaty of Union does not contemplate separation but rather proclaims that "the two Kingdoms of England and Scotland shall (...) for ever after be united into one Kingdom"181 And like Quebec: Catalonia, Flanders, and Scotland are neither colonies possessing a right to external self-determination nor are they victims of repression which could trigger the application of remedial succession. In short, Catalonia, Flanders and Scotland seem only to be entitled to internal

177 See Constitution Act 1867, as amended by the Constitution Act 1982, which came into force on 17 April 1982, available at the Justice Laws website of the Government of Canada http://laws-lois.justice.gc.ca/eng/const/. On the issue of to what extent constitutions can make provisions for secession, see: David Haljan, Constitutionalising Secession, Hart Publishing, Oxford and Portland, 2014, pp. 1920.

178 See the text of the Spanish Constitution Constitution, BOE n. 311, 29 December 1978, pp. 29313-29424, available at https://www.boe.es/diario boe/txt. php?id=BOE-A-1978-31229 and the text of the Belgian constitution, available at the webpage of the Belgian Senate in its French version (http://www.senate.be/ doc/const fr.html), Dutch version (http://www.senate.be/doc/const nl.html) and German version (http://www.senate.be/deutsch/const de.html).

179 Article 2 of the Spanish Constitution stipulates that "The Constitution is based on the indissoluble unity of the Spanish nation, the common and indivisible country of all Spaniards; it recognises and guarantees the right to autonomy of the nationalities and regions of which it is composed, and the solidarity amongst them all" (English translation GMG). The original Spanish text reads as follows: "La Constitución se fundamenta en la indisoluble unidad de la Nación española, patria común e indivisible de todos los españoles, y reconoce y garantiza el derecho a la autonomía de las nacionalidades y regiones que la integran y la solidaridad entre todas ellas".

180 Article 149.1.32 of the Spanish Constitution stipulates that the "State holds exclusive competence over (...) authorisation for popular consultations through the holding of referendums" (English translation GMG). Furthermore, the Constitution arguably authorises the use of military force to combat any attempt of secession; according to Article 155.1 of the Constitution "If an Autonomous Community does not fulfil the obligations imposed upon it by the Constitution or other laws, or acts in a way seriously prejudicing the general interests of Spain, the Government, after lodging a complaint with the President of the Autonomous Community and failing to receive satisfaction therefore, may, following approval granted by an absolute majority of the Senate, take the measures necessary in order to compel the latter forcibly to meet said obligations, or in order to protect the above-mentioned general interests" (English translation GMG).

181 Union with Scotland Act, 1706, 6 Ann., c 11. 
self-determination, which they already possess. ${ }^{182}$ However, the State of which they are part may have an obligation to negotiate when there is a clear majority in favour of external self-determination. This can be observed from the Canadian ruling, but also from the willingness of the British Government to negotiate with Scotland over the referendum. ${ }^{183}$

Unlike in the Quebec example, however, the debates over Catalan, Flemish, and Catalan secession also occur within the context of the EU, which provides a unique setting through which self-determinations claims can be considered. ${ }^{184}$

\section{Membership of International Organisations}

The question of membership of international organisations is of paramount importance within the independence polemic and is an issue which has been fiercely debated in the three regions at stake. The advocates of the so-called "Independence in Europe" movement often take the European dimension for granted; assuming either that the new States would automatically possess EU membership upon their independence or, at the very least, that they would gain admission through an expedited and streamlined process. ${ }^{185}$

However, this argument seems to deviate from what some scholars have named the 'Barroso doctrine'. ${ }^{186}$ In September 2012, during an interview

182 For further explanation regarding the process of devolution of powers to these regions, see Chapter 3, sections 2, 3 and 4.

183 See Chapter 2, section 4.

184 See Chapter 1 , section 1.

185 See the Advisory Council for the National Transition report n. 6, "Paths for Catalonia's integration in the European", which makes references to the possible permanence scenario and also an $a d$ hoc accession scenario. The report is available at $\quad$ http://presidencia.gencat.cat/web/.content/ambits actuacio/consells assessors/catn/informes publicats/inf 6 angles.pdf. For Scotland, see the report of the Scottish Government "Scotland in the European Union", in which references are made to membership to the EU "from within" and a smooth transition to independent EU membership. The report is available at, www.scotland.gov.uk/ Resource/0043/00439166.pdf.

186 See on the Barroso doctrine, Xavier Cuadras Morató (ed.), Catalonia: A New Independent State in Europe?: A Debate on Secession within the European Union, Routledge, London, 2016, pp. 198, 204 and 217; Sionaidh Douglas-Scott, "How easily could an independent Scotland join the EU?", Oxford Legal Studies Research Paper No. 46/2014, July 2014, pp. 5-8; and Daniel Kenealy, "How Do You Solve a Problem like Scotland? A proposal Regarding 'Internal Enlargement', Journal of European Integration 36, pp. 588-589. 
with the BBC and again in a December 2012 letter to the House of Lords, the former European Commission President José Manuel Barroso stressed that a new State that is created by secession from an EU Member State would have to apply for membership in its own right, following the EU's accession procedure. Corroborating this opinion, the former President of the European Council, Herman Van Rompuy, stated in December 2013 (coinciding with the announcement of Catalan sovereignty query) that a new independent State would, by the fact of its independence, become a third country with respect to the Union and the treaties would, from the day of its independence, no longer apply on its territory. ${ }^{187}$ Similarly, The Wall Street Journal reported Joaquin Almunia's statement: "If one part of a territory of a Member State decides to separate, the separated part isn't a member of the European Union". 188

Since 2004, several Parliamentary questions have been posed to the Commission regarding the consequences of the independence of a part of an EU Member State. On 12 February 2004, the European Commission was confronted with a question from British MEP, Eluned Morgan, who asked whether a newly independent region would have to leave the EU and then apply for accession afresh or whether the Algerian precedent ${ }^{189}$ would be applicable to such a situation. ${ }^{190}$ The answer provided by the then President of the Commission, Romano Prodi, is commensurate with the 'Barroso doctrine', whereby it was stated:

"When a part of the territory of a Member State ceases to be a part of that state, e.g. because that territory becomes an independent state, the treaties will no longer apply to that territory. In other words, a newly independent region would, by the fact of its independence, become a third country with respect to the Union and the treaties would, from the day of its independence, not apply anymore on its territory.

Under article 49 of the Treaty on European Union, any European State which respects the principles set out in Article 6(1) of the Treaty on European Union may apply to become a member of the Union. An

187 Remarks by President of the European Council Herman Van Rompuy, on Catalonia, EUCO 267/13 of 12 November 2013.

188 "Almunia Says Catalonia Would Need to Leave EU if it Secedes From Spain", The Wall Street Journal, September 16, 2013, available at: http://online.wsj.com/news/ articles/SB10001424127887323527004579079031402636014.

189 See Chapter 1 , section 1.

190 Parliamentary question by Eluned Morgan (PSE), P-0524/04, 12 February 2004, available at http://www.europarl.europa.eu/sides/getDoc.do?type=WQ\&reference=P2004-0524\&language=EN . 
application of this type requires, if the application is accepted by the Council acting unanimously, a negotiation on an agreement between the Applicant State and the Member States on the conditions of admission and the adjustments to the treaties which such admission entails. This agreement is subject to ratification by all Member States and the Applicant State". ${ }^{191}$

In 2012, six Parliamentary questions were addressed to the Commission, on the following subjects: referendum on independence in Scotland; ${ }^{192}$ possibility of secession in a Member State and impact on citizens; ${ }^{193}$ independent States and EU membership; ${ }^{194}$ status of the United Kingdom if Scotland leaves; ${ }^{195}$ and secession within the Union and European citizenship. ${ }^{196}$ The answers given by the European Commission did not deviate from the previous answers. In fact, the answer to some of these questions was a simple reference to answer given in 2004, since according to the Commission the "legal context has not changed". ${ }^{197}$ However, a new dimension to this debate was introduced in the Parliamentary questions of 25 July 2012 and 17 September 2012, i.e., the issue of European citizenship. In an answer given to the first question, the Commission pointed out that

191 Answer given by Mr Prodi on behalf of the Commission, P-0524/2004, 1 March 2004, available at http://www.europarl.europa.eu/sides/getAllAnswers.do?reference=P2004-0524\&language $=\mathrm{EN}$.

192 Parliamentary question by Ramón Tremosa i Balcells (ALDE), E-000395/2012, 23 January 2012, available at http://www.europarl.europa.eu/sides/getDoc. do?pubRef=- $/ / \mathrm{EP} / / \mathrm{TEXT}+\mathrm{WQ}+\mathrm{E}-2012-000395+0+\mathrm{DOC}+\mathrm{XML}+\mathrm{V0} / / \mathrm{EN}$.

193 Parliamentary question by Mara Bizzotto (EFD), E-007453/2012, 25 July 2012, available at http://www.europarl.europa.eu/sides/getDoc.do?pubRef=-//EP// TEXT+WQ+E-2012-007453+0+DOC+XML+V0//EN.

194 Parliamentary question by David Martín (S\&D), P-009756/12, 25 October 2012, available at http://www.europarl.europa.eu/sides/getDoc.do?type=WQ\&reference=P2012-009756\&language $=$ EN.

195 Parliamentary question by Gerard Batten (EFD), P-009862/12, 29 October 2012, available at http://www.europarl.europa.eu/sides/getDoc.do?type=WQ\&reference=P2012-009862\&language $=$ EN.

196 Parliamentary question by Izaskun Bilbao Barandica (ALDE), Ramon Tremosa i Balcells (ALDE), Salvador Sedó i Alabart (PPE) and Raül Romeva i Rueda (Verts/ALE), E-008133/2012, 17 September 2012, available at http://www. europarl.europa.eu/sides/getDoc.do?pubRef=-//EP//TEXT+WQ+E-2012$008133+0+\mathrm{DOC}+\mathrm{XML}+\mathrm{V} 0 / / \mathrm{EN}$.

197 Joint answer given by Mr Barroso on behalf of the Commission, E-007453/2012, 28 August 2004, available at http://www.europarl.europa.eu/sides/getAllAnswers. do?reference=P-2012-009756\&language=EN. The reference to previous answers can also be seen in the answer given by President Juncker on behalf of the Commission, E-009058/2014, 9 February 2015, available at http://www.europarl. europa.eu/sides/getAllAnswers.do?reference=E-2014-009058\&language=EN. 
"in accordance with Article 20 of the Treaty on the Functioning of the European Union (TFEU), EU citizenship is additional to and does not replace national citizenship (that is, the citizenship of an EU Member State). It also confirms that in the hypothetical event of a secession of a part of an EU Member State, the solution would have to be found and negotiated within the international legal order. Any other consideration related to the consequences of such event would be of a conjectural nature" (emphasis added, GMG). ${ }^{198}$

The last Parliamentary question on this issue was posed in 21 July 2015 concerning "Catalonia's unilateral declaration of independence". ${ }^{199}$ In principle, the answer given by President Jean-Claude Juncker on behalf of the Commission follows the same logic: ${ }^{200}$ after clarifying that it is not the role of this body to express a position "on questions of internal organisation related to the constitutional arrangements of a particular Member State", the Commission referred back to previous Parliamentary questions on the same topic. However, the answer given in the Spanish version ${ }^{201}$ differed from the English version. The Spanish version contained an extra third paragraph (that was not present in the English version) with references to national identity, territorial integrity and constitutional law, which concluded with the following statement:

"The determination of the territory of a member state is only established by national constitutional law, and not by a decision of a regional parliament contrary to the constitution of that state". ${ }^{202}$

198 Answer given by Mr Barroso on behalf of the Commission, P-009756/12 and P-009862/12, 3 December 2012, available at http://www.europarl.europa.eu/ sides/getAllAnswers.do?reference=E-2012-007453\&language=EN.

199 Parliamentary question by Santiago Fisas Ayxelà (PPE), E-011776/15, 21 July 2015, available at http://www.europarl.europa.eu/sides/getDoc.do?pubRef=-// $\mathrm{EP} / / \mathrm{TEXT}+\mathrm{WQ}+\mathrm{E}-2015-011776+0+\mathrm{DOC}+\mathrm{XML}+\mathrm{V} 0 / / \mathrm{EN}$.

200 Answer given by President Juncker on behalf of the Commission, E-011776/2015, 21 Septiembre 2015, available at http://www.europarl.europa.eu/sides/ getAllAnswers.do?reference=E-2015-011776\&language=EN.

201 The text of the Spanish version reads as follows: "La Comisión recuerda en este contexto que, de conformidad con lo dispuesto en el artículo 4, apartado 2, del TUE, la Unión debe respetar la «identidad nacional [de los Estados miembros], inherente a las estructuras fundamentales políticas y constitucionales de éstos, también en lo referente a la autonomía local y regional. Respetará las funciones esenciales del Estado, especialmente las que tienen por objeto garantizar su integridad territorial». La determinación del territorio de un Estado miembro está únicamente establecida por el Derecho constitucional nacional, y no por una decisión de un Parlamento autonómico contraria a la constitución de dicho Estado".

202 Translation by the author. The original Spanish text reads as follows: " $L a$ determinación del territorio de un Estado miembro está únicamente establecida 
Furthermore, a European citizens' initiative was also presented under the title "Fortalecimiento de la participación ciudadana en la toma de decisiones sobre la soberanía colectiva" (Strengthening citizen participation in decision-making on collective sovereignty). The primary objective of this initiative was to clarify what would happen to an EU Member State in the event of a State succession scenario. However, the request for registration of this initiative was refused on the basis that the "initiative falls manifestly outside the framework of the Commission's powers to submit a proposal for a legal act of the Union for the purpose of implementing the Treaties". ${ }^{203}$

The 'Barroso doctrine' is supported by international law and the practice of international organisations. As Shaw points out, ${ }^{204}$ practice seems to show a certain tendency to succession to some categories of multilateral treaties and to certain multilateral conventions. However, there exists no general rule on treaty succession, and the application of the principles contained in the 1978 Vienna Convention is largely determined on a case by case basis. Article 34 of the 1978 Vienna Convention on Succession of States in Respect of Treaties appears to suggest that a new State's succession to the treaty obligations of its former parent State is automatic:

"When a part or parts of a territory of a State separate to form one or more States, whether or not the predecessor state continues to exist: (a) any treaty in force at the date of the succession of States in respect of the entire territory of the predecessor State continues in force in respect of each successor State so formed". 205

With respect to treaties governing membership in international organisations, however, the effect of Article 34 is limited by the operation of Article 4 of the same Convention, which stipulates that the Convention applies:

"without prejudice to the rules concerning acquisition of membership and without prejudice to any other relevant rules of the organization". ${ }^{206}$

In other words, the membership rules of a given international organisation take precedence over the provisions of the Vienna Convention. As the UN

por el Derecho constitucional nacional, y no por una decisión de un Parlamento autonómico contraria a la constitución de dicho Estado".

203 C(2012)3689 final, SG-Greffe (2012) D/8977, 30 May 2012.

204 Malcom N. Shaw, International Law, Cambridge University Press, Cambridge, 2014 (7th edition), p. 703.

205 Vienna Convention on Succession of States in respect of Treaties, 23 August 1978 (Registered ex officio on 6 November 1996), UNTS, 1946, p. 33356, Article 34.

206 Vienna Convention on Succession of States in respect of Treaties, 23 August 1978 (Registered ex officio on 6 November 1996), UNTS, 1946, p. 33356, Article 4. 
General Assembly's International Law Commission explained during the drafting of the Convention:

"In many organizations, membership, other than original membership, is subject to a formal process of admission. Where this is so, practice appears now to have established the principle that a new State is not entitled automatically to become a party to the constituent treaty and a member of the organization as a successor State, simply by reason of the fact that at the date of the succession its territory was subject to the treaty and within the ambit of the organization". ${ }^{207}$

Although the Vienna Convention does not constitute customary international law, ${ }^{208}$ it does tend to reflect the approach of international organisations to membership issues arising out of the creation of new States on the former territory of member States. ${ }^{209}$

The UN was first confronted with the question of treaty succession in 1947, when British India, an original member of the UN, achieved independence and was immediately partitioned into two separate States: India and Pakistan. After considerable internal debate, the UN concluded that India continued British India's legal personality, including its membership of the UN, whereas Pakistan would be required to apply for UN membership as a new State. In reaching this conclusion, the UN's Sixth (Legal) Committee established general guidelines for evaluating succession of UN membership:

"1. That, as a general rule, it is in conformity with legal principles to presume that a State which is a Member of the Organization of the United Nations does not cease to be a Member simply because its Constitution or its frontier have been subjected to changes, and that the extinction of the State as a legal personality recognized in the international order must be shown before its rights and obligations can be considered thereby to have ceased to exist.

207 Commentary on Article 4, Draft Articles on Succession of States in respect of Treaties with commentaries, Report of the Commission to the General Assembly, Yearbook of the International Law Commisssion, 1974, Vol. II, Part One, p. 177.

208 See also Opinion No. 13, Conference on Yugoslavia, Arbitration Commission, 96 ILR, pp. 726-728: "there are few well-established principles of international law that apply to state succession. Application of these principles is largely to be determined on a case by case basis, though the 1978 and 1983 Vienna Conventions do offer some guidance". See also Malcom N. Shaw, International Law, Cambridge University Press, Cambridge, 2014 (7th edition), p. 695.

209 Malcom N. Shaw, International Law, Cambridge University Press, Cambridge, 2014 (7th edition), p. 695. 
2. That when a new State is created, whatever may be the territory and populations which it comprises and whether or not they formed part of a State Member of the United Nations, it cannot under the system of the Charter claim that status of a Member of the United Nations unless it has been formally admitted as such in conformity with the provisions of the Charter.

\section{Beyond that, each case must be judged according to its merits". ${ }^{210}$}

Practice has provided further examples which support the principle that a member State of the UN retains its membership despite a loss of territory, while a new State established on the former territory of a member State must apply for membership as a new State.

For example, when Singapore achieved its independence from Malaysia in 1965, the latter retained its international identity and UN membership and the former was admitted as a new State. ${ }^{211}$ Moreover, in the case of Bangladesh, after separating from Pakistan, the remaining territory, which comprised former West Pakistan, was considered to be the continuing State: "Pakistan's UN membership continued, whereas Bangladesh was eventually admitted to the UN separately, on 17 September 1974". ${ }^{212}$

Similarly, after the dissolution of the USSR in 1990-91, the Russian Federation was regarded as continuing the legal personality of the USSR. In that case, Russia not only continued the USSR's membership of the UN, but also retained its permanent membership of the Security Council. ${ }^{213}$ More recently, South Sudan, after achieving its independence, was admitted separately to the UN while Sudan continued its membership. ${ }^{214}$

210 Doc. A7CN.4/149 and Add. 1 (The succession of States in relation to membership in the United Nations: memorandum prepared by the Secretariat), reproduced in ILCYB 1962, Vol. II, p. 101.

211 See Security Council resolution 213 (1965) on admission of Singapore to membership in the United Nations, 15 March 1965.

212 James Crawford and Alan Boyle, Annex A-Opinion: Referendum on the Independence of Scotland-International Law Aspects, Scotland Analysis: Devolution and the Implications of Scottish Independence, United Kingdom Government, 2013, p. 79.

213 Boris Yeltsin, President of the Russian Federation, informed the Secretary-General, in a letter dated 24 December 1991, that the membership of the Soviet Union in the Security Council and all other United Nations organs was being continued by the Russian Federation. In this communication, the support of the 11 member countries of the Commonwealth of Independent States to continuing membership of the Russian Federation was stressed.

214 Resolution 65 (XXXVIII) of 14 July 2011, Admission of the Republic of South Sudan to membership in the United Nations, Official Records of the General Assembly, 
Like the UN Charter, the EU's governing treaties do not contain any provisions for dealing with secession or the membership it engenders. However, membership provisions do exist. EU membership is limited to States that meet certain criteria and if these criteria are fulfilled, they are admitted through a unanimous vote by the existing Member States. To allow for automatic treaty succession would be to allow a new State to bypass the EU's membership rules. Moreover, the EU's governing treaties allocate representation in the EU institutions and access to structural funds proportionally among the Member States, and these treaties must consequently be amended each time a new State is admitted. ${ }^{215}$ Although the EU is generally defined as a sui generis international organisation, with its own internal rules, ${ }^{216}$ the Treaties on which the EU is founded have been negotiated and concluded in accordance with the general principles of international law.

As pointed out in section 1.2, the question of the continuing State is of great importance, especially with regard to the issue of membership of international organisations. International law generally presumes the continued existence of States, even when those States experience loss of territory or population since the extinction of States is extremely rare. Michael P. Scharf identified six factors that the international community has considered when determining whether a State has dissolved or whether a potential successor territory has inherited its legal personality:

"whether the potential successor has: (a) a substantial majority of the former [State's] territory (including the historic territorial hub), (b) a majority of its population, (c) a majority of its resources, (d) a majority of its armed forces, (e) the seat of government and control of most central government institutions, and (f) entered into a devolution agreement [i.e., an agreement on continuation of legal personality] (. ..) with the other components of the former State". 217

Sixty-fith Session, Supplement No. 49 (A/65/L.84 + Add.1).

215 Compare on this issue, inter alia, Henri de Waele, "Afscheiding van delen van EU-lidstaten - de Europeesrechtelijke implicaties", SEW, 2016, pp. 8-9; Phedon Nicolaides, "Withdrawal from the European Union: A Typology of Effects', Maastricht Journal of European and Comparative Law, 2013, pp. 209-219, Henri de Waele, "Afscheiding van delen van EU-lidstaten - Een beschouwing vanuit internationaal en Europeesrechtelijk perspectief", Ars Aequi vol. 10, 2014 pp. 722-725.

216 Paul Craig and Gráinne de Búrca, EU Law: text, cases ans materials, Oxford University Press, Oxford, 2015 (6 $6^{\text {th }}$ edition), pp. 356-357; Bruno De Witte, 'EU Law: Is it International Law?', in Catherine Barnard and Steve Peers (eds.), European Union Law, Oxford University Press, Oxford, 2014, pp. 174-194.

217 Michael P. Scharf, "Musical Chairs: The Dissolution of States and Membership in the United Nations", 28 Cornelll International Law Journal, 1995, pp. 34-35. 
Where an established State experiences secession but nonetheless continues to satisfy most or all of the six factors, it is deemed to continue the predecessor State's legal personality: its sovereign territorial reach is compromised but its legal existence is unaffected.

The Scharf criteria are not immediately applicable to the cases of Catalonia or Scotland. ${ }^{218}$ However, their application to the Flemish situation is more interesting. This is due to the fact that Flanders occupies the majority of Belgium's territory, and controls the lion's share of Belgium's economic wealth. Therefore Flanders would be the most obvious candidate to inherit Belgium's legal personality, in a State succession scenario, applying the Scharf criteria.

\section{Automatic State Succession to Human Right Treaties}

The special status of human rights treaties in a State succession scenario merits special attention, ${ }^{219}$ since they lay down obligations that are "owed directly to individuals and often provide for direct access for individuals to international mechanism". ${ }^{220}$ In this sense, there is a risk, that when a State party to a human rights treaty experiences a State succession, that individuals who were formerly protected by those treaties find themselves deprived of such a protection due to the operation of the State succession itself. ${ }^{21}$ This question was addressed by the UN Human Rights Committee in relation to the ICCPR. Under the title "Continuity of obligations", General Comment No. 26 of the UN Human Rights Committee concluded that

"once the people are accorded the protection of the rights under the Covenant, such protection devolves with territory and continues to belong to them, notwithstanding change in Government of the State party, including dismemberment in more than one State or State succession (...)".222

218 See on Scotland Matthew Happold, "Independence: In or Out of Europe? An Independent Scotland and the European Union", The International and Comparative Law Quarterly Vol. 49, No. 1, pp. 28-29.

219 See point 2 of the UN Commission on Human Rights Resolution 1995/18, Succession of States in respect of international human rights treaties, 24 February 1995, E/ CN.4/RES/1995/18 which "emphasizes the special nature of the human rights treaties aimed at the protection and promotion of human rights and fundamental freedoms".

220 Malcom N. Shaw, International Law, Cambridge University Press, Cambridge, 2014 (7th edition), p. 711.

221 Ibid.

222 UN Human Rights Committee, CCPR General Comment No. 26: Continuity of Obligations, 8 December 1997, CCPR/C/21/Rev.1/Add.8/Rev.1, point No. 4. 
The UN Commission on Human Rights has also dealt with this topic. The Report of the Secretary-General of 28 November 1994 on "Succession of States in respect of international human rights treaties" 223 reflects the work of, not only the Commission on Human Rights, ${ }^{224}$ but several UN bodies dealing with human rights treaties. ${ }^{225}$ Remarkable is the fact that the fifth meeting of persons chairing the human rights treaty bodies (held from 19 to 23 September 1994) not only repeated the recommendation to all successor States to confirm as soon as possible their succession to human rights treaties of which the former predecessor States were States party, but also took the view that

"successor States were automatically bound by obligations under international human rights instruments from the respective date of independence and that observance of the obligations should not depend on a declaration of confirmation made by the Government of the successor State".226

Reference can also be made to the Application of the Genocide Convention case which came before the ICJ. Although the Court was not required to go

${ }^{223}$ UN Commission on Human Rights Report of the Secretary-General, Status of the International Covenants on Human Rights: Succession of States in respect of international human rights treaties, 28 November 1994, E/CN.4/1995/80.

224 The report refers to Resolution 1993/23 of 5 March 1993 of the Commission on Human Rights, entitled "Succession of States in respect of international human rights treaties" and adopted at at its forty-ninth session. This resolution encouraged "successor States to confirm officially that they continued to be bound by obligations under relevant international human rights treaties" (emphasis added GMG). It also makes reference to the Commission on Human Rights resolution 1994/16 of 25 February 1994, which "emphasized the special nature of the treaties aimed at the protection of human rights and fundamental freedoms and reiterated its call to successor States which had not yet done so to confirm to appropriate depositaries that they continued to be bound by obligations under international human rights treaties" (emphasis added GMG).

225 In relation to the Human Rights Committee, the report makes a note on the decision of 7 October 1992, whereby the Committee emphasized that all people within the territory of a new State that constituted a part of the former Yugoslavia were entitled to the guarantees of the Covenant. In relation to the Committee on the Elimination of Racial Discrimination, the General Recommendation XII (42) is cited. This Recommendation encouraged "successor States that had not yet done so to confirm to the Secretary-General, as depositary of the International Convention on the Elimination of All Forms of Racial Discrimination, that they continued to be bound by obligations under that Convention, if predecessor States had been parties to it" (emphasis added GMG).

226 UN Commission on Human Rights Report of the Secretary-General, Status of the International Covenants on Human Rights: Succession of States in respect of international human rights treaties, 28 November 1994, E/CN.4/1995/80, p. 4. 
into the question of State succession in this decision since at all relevant times Bosnia was party to the Genocide Convention on the date of the application's filing, the ICJ did remark, however, that this was
"without prejudice as to whether or not the principle of "automatic succession" applies in the case of certain types of international treaties or conventions".227

In their separate opinions, Judges Parra-Aranguren, Shahabuddeen and Weeramantry expressly stated that the humanitarian nature of the Genocide Convention in conjunction with its object and purpose

"support a construction being placed upon them to the effect that they constitute the expression of a unilateral undertaking by existing parties to treat successor States as parties with effect from the date of emergence into independence". 228

This idea was also reiterated by the International Criminal Tribunal in relation to the former Yugoslavia:

"It may be now considered in international law that there is automatic state succession to multilateral treaties in the broad sense, i.e., treaties of universal character which express fundamental human rights. It is noteworthy that Bosnia and Herzegovina itself recognised this principle before the ICJ". ${ }^{229}$

The ECtHR has also had the opportunity to address this issue. In Bijelic $v$ Montenegro and Serbia ${ }^{230}$ the Court concluded that the ECHR applied to

227 Application of the Convention on the Prevention and Punishment of the Crime of Genocide (Bosnia and Herzegovina v Yugoslavia), Preliminary Objections, 1996, ICJ Reports, p. 595, para. 20-24.

228 Separate Opinion of Judge Shahabuddeen, Application of the Convention on the Prevention and Punishment of the Crime of Genocide (Bosnia and Herzegovina v Yugoslavia), Preliminary Objections, 1996, ICJ Reports, p. 637. See also Separate Opinion of Judge Weeramantry, Application of the Convention on the Prevention and Punishment of the Crime of Genocide (Bosnia and Herzegovina v Yugoslavia), Preliminary Objections, 1996, ICJ Reports, pp. 640-655 and Separate Opinion of Judge Parra-Aranguren, Application of the Convention on the Prevention and Punishment of the Crime of Genocide (Bosnia and Herzegovina v Yugoslavia), Preliminary Objections, 1996, ICJ Reports, pp. 656-657.

229 Prosecutor v Delalic et al 'Judgment' (Appeals Chamber) (20 February 2001) Case IT-96-21 (ICTY), para. 111.

230 Case Bijelic v Montenegro and Serbia, Application No. 19890/05, 11 June 2009. For a further analysis of this decision, see Benjamin E Brockman-Hawe, "European Court of Human Rights Bijelic v Montenegro and Serbia (Application No 19890/05) 
Montenegro retroactively from the date of its declaration of independence, given the principle that
"fundamental rights protected by international human rights treaties should indeed belong to individuals living in the territory of the State party concerned, notwithstanding its subsequent dissolution or succession".231

The similarity of this sentence with General Comment No. 26 of the UN Human Rights Committee is remarkable although expected, since in its reasoning the ECtHR embraced the conclusions reached by that Committee in the aforementioned Comment. ${ }^{232}$

It will not come as any surprise that human rights treaty bodies promote the automatic application of the conventions and treaties within their preview. In this sense, one can agree with Gowlland-Debbas when she states that

"the human rights treaty bodies, anxious to preserve the application of their respective treaties, have pushed for their automatic application to a seceding state from the date of its independence". ${ }^{233}$

However, the automatic accession to international human rights treaties is not yet accepted as a rule of customary international law. Due to the special nature of these treaties, it seems that there is a tendency to accept the idea that they are binding ipso iure on the successor States. ${ }^{234}$

As will be discussed in Chapter 5 , the position of newly independent States in respect to human rights treaties is for the purposes of this thesis of particular importance, especially in relation to the ECHR. ${ }^{235}$

Judgment of 11 June 2009", International and Comparative Law Quarterly, 59, 2010, pp. 845-867.

231 Case Bijelic v Montenegro and Serbia, Application No. 19890/05, 11 June 2009, para. 69.

${ }^{232}$ Case Bijelic v Montenegro and Serbia, Application No. 19890/05, 11 June 2009, para. 58.

233 Vera Gowlland-Debbas, "The Role of the International Court of Justice in the Development of the Contemporary Law of Treaties", in Christian J. Tams and James Sloan (eds.): The Development of International Law by the International Court of Justice, Oxford Scholarship Online, Oxford, January 2014, pp. 44-45.

234 Menno Kamminga, "State Succession in Respect of Human Rights Treaties", European Journal of International Law, p. 483.

235 See Chapter 5, section 2. 


\section{State Succession and its Effects on Nationality of Natural Persons: The attribution of Nationality upon Independence}

\subsection{UN - International Law Commission}

The codification of the law of State succession has been a long process and not an especially easy one. In 1949, the ILC at its first session selected the topic of "succession of States and governments" as one of the topics for codification. Nationality matters, which fell under the title "Status of the inhabitants", constituted the first part of the codification efforts under the title "Succession in respect of matters other than treaties". ${ }^{236}$ However, in view of the breadth and complexity of the topic it was later narrowed down to the economic aspects of succession. Nationality was not included therein. ${ }^{237}$ It was not until 1993 that the ILC decided to include on its agenda (as one of two new topics) the question of State succession and its impact on the nationality of natural and juridical persons. The General Assembly adopted Resolution 55/153 on Nationality of natural persons in relation to the succession of States on 12 December 2000, which included the articles developed by the ILC as an annex. ${ }^{238}$

In those Articles, the ILC proposes a presumption of nationality for those individuals having a habitual residence in the territory affected by the succession of States. ${ }^{239}$ This presumption of change of nationality, as clarified by the ILC, is only an interim presumption aimed at avoiding statelessness pending the adoption of domestic nationality legislation. The decision in each specific case was to be taken in accordance with other applicable rules and principles and in view of the different modes of State succession. Thus Part II of the Draft Articles identifies different State succession scenarios, with different rules applicable to each situation: the transfer of part of the territory; the unification of States; the dissolution of a State; and the separation of part or parts of the territory.

${ }^{236}$ Resolution 1686 (XVI) of 18 December 1961, Future work in the field of the codification and progressive development of international law, Official Records of the General Assembly, Fifteenth Session, Supplement No. 9 (A/4425).

237 Vaclav Mikulka, Special Rapporteur Succession of States with respect to Nationality / Nationality in relation to the succession of States 'First report on State succession and its impact on the nationality of natural and legal persons' A/CN.4/467, 1995, (Mikulka Report) para. 5 - 6 .

238 International Law Commission, Articles on Nationality of Natural Persons in Relation to the Succession of States (With Commentaries), 3 April 1999, Supplement No. 10 (A/54/10).

239 International Law Commission, Articles on Nationality of Natural Persons in Relation to the Succession of States (With Commentaries), 3 April 1999, Supplement No. 10 (A/54/10), Article 5. 
As for specific principles, Part II lists the following factors which are important for the purposes of attributing nationality: (1) habitual residence, (2) appropriate legal connection with one of the constituent units of the predecessor State, or (3) birth in the territory. If none of these criteria are applicable, the ILC Draft Articles acknowledged this by introducing a 'catch all' criterion of 'any other appropriate connection' 240 to the territory. It was explained that:

"the Commission chooses to describe the link which must exist between the persons concerned and a particular State concerned by means of the expression 'appropriate connection', which should be interpreted in a broader sense than the notion of 'genuine link'. The reason for this terminological choice is the paramount importance attached by the Commission to the prevention of statelessness, which, in this particular case, supersedes the strict requirement of an effective nationality". ${ }^{241}$

Hereinafter, some further remarks will be made on the different situations of State succession. The focus shall be placed on separation (Catalonia and Scotland) and dissolution (Flanders). ${ }^{242}$

Regarding the case of separation, Article 24 of the ILC Draft Articles establishes as a general rule the principle that the nationals of the predecessor State that are habitually resident in the territory affected by the succession of States should acquire the nationality of the successor State on the date of such succession. This provision further states that citizens of a predecessor State that are habitually resident elsewhere and have "an appropriate legal connection" to a successor State should be offered the citizenship of that successor State and this offer of citizenship should be subject to a right of choice. ${ }^{243}$ Regarding citizens

240 See Draft Articles on Nationality of Natural Persons in relation to the Succession of States with commentaries, para. 9, p. 34.

241 See Draft Articles on Nationality of Natural Persons in relation to the Succession of States with commentaries, para. 9, p. 34.

242 As noted in section 3, the application of the Scharf criteria regarding State continuity in the case of Belgium may be lead to the conclusion, since Flanders comprises the majority of Belgium's territory and population and economic wealth, it would be the most obvious candidate to inherit Belgium's legal personality in case the Belgian State ceases to exist. The other option is that, ignoring the Scharf criteria, Flanders would become an independent State and Belgium will continue to exist as a State, as the continuing State but with a considerable reduction of its territory.

${ }^{243}$ Compare this provision with Article 8 (2) of Draft Articles on Nationality of Natural Persons in relation to the Succession of States, which states that "a successor State shall not attribute its nationality to persons concerned who have their habitual residence in another State against the will of the persons concerned unless they would otherwise become stateless". 
of third States, there is no such obligation to offer the nationality of the successor or the predecessor State. The Draft Articles only stipulate that the habitual residence status of such citizens should not be prejudiced by the succession of States. ${ }^{244}$

It is remarkable that Article 25 of the ILC Draft Articles, under the heading of "withdrawal of the nationality of the predecessor State" seems to establish an obligation on the predecessor State to withdraw its nationality "from persons concerned qualified to acquire the nationality of the successor State". As such, nationals of the predecessor State that are habitually resident on the territory affected by the State succession should acquire the nationality of the successor State. In practice this rule would mean that in a scenario whereby Catalonia, Flanders or Scotland would become independent States, that the Spanish, Belgian or British nationality and by extension EU citizenship, would be withdrawn from those who are habitually resident on the territory of the new independent State. Strictly speaking, this means leaving the decision to withdraw the EU citizenship status in the hands of the new independent State.

However, this affirmation may not be $100 \%$ correct. The wording of Article 25 must be read in conjunction with Article 24. Article 24 tempers the imperative wording of Article 25, since the attribution of nationality by the successor State shall be done "unless otherwise indicated by the exercise of a right of option". As pointed out in the commentary to Article 25, this provision is based on State practice which, despite some inconsistencies, indicates to a large extent that such withdrawal has been an automatic consequence of the acquisition by persons concerned of the nationality of a successor State. Thus,

"The withdrawal of the nationality of the predecessor State is subject to two conditions. First, that persons qualified to acquire the nationality of the successor State did not opt for the retention of the nationality of the predecessor State. This condition is spelled out in the chapeau of article 24 to which article 25, paragraph 1, refers. Second, that such withdrawal shall not occur prior to the effective acquisition of the successor State's nationality".

However, if that right of option for the nationality of the predecessor State is not provided or is not exercised by the person concerned, the result will be the withdrawal of the nationality of the predecessor State and,

244 International Law Commission, Articles on Nationality of Natural Persons in Relation to the Succession of States (With Commentaries), 3 April 1999, Supplement No. 10 (A/54/10), Article 14. 
importantly for the purposes of this research, the nationality that triggers the acquisition of EU citizenship status.

Another important feature in the ILC Draft Articles is the attempt to identify the role and proper place for the wishes of an individual. For instance, Article 26 states that both the predecessor and successor States shall grant a right of option to all persons concerned covered by Articles 24 and 25(2) who are qualified to have the nationality of both the predecessor and successor State or of two or more successor States. In more general terms, Article 6 establishes that the States involved in the State succession should take all appropriate steps to ensure that persons concerned will be informed, within a reasonable time period, of the effect of its legislation on their nationality, of any choices they may have thereunder, as well as of the consequences that the exercise of such choices will have on their nationality status. Strictly speaking, no right of option is enshrined in that provision. However, it reflects the importance attached to ensuring that persons concerned

"are not reduced to a purely passive role as regards the impact of the succession of States on their individual status or confronted with adverse effects of the exercise of a right of option of which they could objectively have no knowledge when exercising such right". ${ }^{245}$

This issue only arises, of course, when a person finds herself or himself having ties with more than one State concerned. The reference to "choices" should be understood more broadly than simply an option between different nationalities. The measures to be taken by States should be "appropriate" and timely, so as to ensure that any rights of choice to which persons concerned may be entitled to under their legislation are indeed effective and exercisable in practice.

Regarding the case of dissolution, the Draft Articles also begin with the general rule that nationals of the predecessor State that are habitually resident in the territory of the successor State shall acquire the nationality of the successor State. The criterion of "having an appropriate legal connection" is reiterated in Article 22(b). The application of the criteria in Article 22 may result in the situation whereby an individual is able to acquire the nationality of more than one successor State in which case, the attribution of nationality will depend on the individual's choice in accordance with Article 23.

245 International Law Commission, Articles on Nationality of Natural Persons in Relation to the Succession of States (With Commentaries), 3 April 1999, Supplement No. 10 (A/54/10), p. 30. 
In comparison with the separation discussion above, in the case of dissolution there is no provision dealing with the withdrawal of the nationality of the predecessor State, which is a logical consequence of the fact that, in the case of dissolution, both the predecessor State and its nationality disappear.

As a final remark, it is necessary to mention that the Draft Articles are not legally binding. In fact, the General Assembly, via Resolution 59/34 of 2 December 2004, invited Governments to submit comments concerning the advisability of transforming the Draft Articles into a legally binding instrument. This matter was further considered by the General Assembly at its sixty-third session, in 2008, and at again its sixty-sixth session, in 2011. By virtue of Resolution 66/92 in 2011, the Assembly decided that, upon the request of any State, it will revert to the question of nationality of natural persons in relation to the succession of States at an appropriate time, in the light of the development of State practice in these matters. Nowadays, the issue of nationality of natural persons in relation to the succession of States has disappeared off General Assembly's agenda.

Within the context of the avoidance of statelessness, and prior to the ILC Draft Articles on Nationality of Natural Persons in Relation to the Succession of States, the issue of statelessness linked to State succession was briefly tackled by the 1961 Convention on the Reduction of Statelessness. ${ }^{246}$ This convention contains, in Article 10, important rules on the avoidance of statelessness within the context of State succession:

"1. Every treaty between Contracting States providing for the transfer of territory shall include provisions designed to secure that no person shall become stateless as a result of the transfer. A Contracting State shall use its best endeavours to secure that any such treaty made by it with a State which is not a party to this Convention includes such provisions.

2. In the absence of such provisions a Contracting State to which territory is transferred or which otherwise acquires territory shall confer its nationality on such persons as would otherwise become stateless as a result of the transfer or acquisition"

246 UN General Assembly, Convention on the Reduction of Statelessness, 30 August 1961, United Nations, Treaty Series, vol. 989, p. 175. 
Three rules can be distinguished in this provision:

1. If territory is transferred by a treaty between Contracting States to the 1961 Convention, this treaty shall include provisions on the nationality of persons, which have to be designed on a way which does not cause any person to become stateless.

2. If territory is transferred by a treaty between a Contracting State to the 1961 Convention and a State which is not a party to this Convention, the Contracting State is obliged to use its best endeavours, in order to include in this treaty provisions on the nationality of persons, which have to be designed on a way which does not cause any person to become stateless.

3. By default of such provisions a Contracting State which acquires territory shall confer its nationality to persons who otherwise would become stateless as result of the transfer or acquisition of territory.

It is remarkable, that Article 10 only gives one single substantive default rule on treaty provisions. The Article does not give any direction for the content of the provisions on nationality which should be included in such a treaty transferring territory.

\subsection{Council of Europe}

The Council of Europe adopted in 1996, through its European Commission for Democracy through Law (the 'Venice Commission'), a Declaration on the Consequences of State Succession for the Nationality of Natural Persons. ${ }^{247}$ The Venice Declaration does not express any particular view on the meaning of nationality and its function in relation to State succession, but from this Declaration emerges a set of principles that the Venice Commission considers relevant. The Venice Commission thus took the following principles as a backbone for its work:

(a) the principle that questions of nationality fall within the national jurisdiction of each State;

(b)the principle that everyone has the right to a nationality, and

(c) the principle that statelessness must be avoided.

247 See Declaration on the Consequences of State Succession for the Nationality of Natural Persons (and commentary), reproduced in Council of Europe, European Commission for Democracy through Law, 'Consequences of State Succession for Nationality' CDL-INF (97). 
The ECN repeats in Article 19 the substance of Article 10(1) of the 1961 Convention:

\begin{abstract}
"In cases of State succession, States Parties concerned shall endeavour to regulate matters relating to nationality by agreement amongst themselves and, where applicable, in their relationship with other States concerned. Such agreements shall respect the principles and rules contained or referred to in this chapter"
\end{abstract}

The ECN establishes as a basic rule that States concerned should regulate the matter amongst themselves in accordance with Article 19.

Article 18 of the ECN formulates specific principles applicable to State succession situations. Article 18 lists several criteria which a successor State must to take into account when either granting or retaining nationality. These are: (1) the genuine and effective link of a person with the State, (2) the habitual residence of a person at the time of State succession, (3) the will of a person, or (4) the territorial origin of a person. Regrettably, the ECN offers no guidance on the weighing of these factors. In their understanding, the drafters of the Convention admitted, that a person having a "substantial connection" with the successor State should, in principle, be entitled to acquire the nationality of that State through procedures laid down by that State. Their main objective was to develop guidelines for States which would enable them to tackle the problem of statelessness, which may arise in State succession situations. ${ }^{248}$

In 2006, the Council of Europe adopted a new specific Convention on the Avoidance of Statelessness in relation to State succession. Although this Convention is primarily concerned with statelessness, it establishes minimum standards that States should observe. These minimum standards are confined to situations where statelessness is the result, and therefore the Convention does not suggest how nationality should be granted. For instance, the Convention stipulates that the successor State should grant nationality to certain nationals of the predecessor State if they would otherwise become stateless. ${ }^{249}$ This group of persons include those who are habitually resident in the successor State, those with a legal bond through federal citizenship, those born there, or having their last habitual residence there before leaving the predecessor State. ${ }^{250}$ The

248 Ineta Ziemele, State Continuity and Nationality: The Baltic States and Russia: Past Present and Future as Defined by International Law, M. Nijhoff, Leiden, 2005, pp. 216-218.

249 Article 5, Council of Europe, Convention on the Avoidance of Statelessness in Relation to State Succession.

250 Ibid., Article 5(2). 
predecessor State is obliged not to withdraw its nationality from any of its nationals who have not acquired the nationality of the successor State, and who would otherwise become stateless. The key Articles are 5 and 6, which determine responsibility of a successor State and predecessor State respectively. Article 5 states:

"1. A successor State shall grant its nationality to persons who, at the time of the State succession, had the nationality of the predecessor State, and who have or would become stateless as a result of the State succession if at that time:

a. they were habitually resident in the territory which has become territory of the successor State, or

$b$. they were not habitually resident in any State concerned but had an appropriate connection with the successor State.

2. For the purpose of paragraph 1, sub-paragraph b, an appropriate connection includes inter alia:

a. a legal bond to a territorial unit of a predecessor State which has become territory of the successor State;

$b$. birth on the territory which has become territory of the successor State;

c. last habitual residence on the territory of the predecessor State which has become territory of the successor State."

Article 6 provides that "A predecessor State shall not withdraw its nationality from its nationals who have not acquired the nationality of a successor State and who would otherwise become stateless as a result of the State succession". It is interesting to compare the wording of this provision with Article 25 of the Draft Articles. It deviates from the wording "the predecessor State shall withdraw its nationality from" which shows, at least, a difference in approach to the attribution of nationality upon independence, most likely due to the focus of the 2006 Convention on the avoidance of statelessness.

Article 7 of the Convention addresses the situation whereby the person might have the right to acquire more than one nationality. It is in this situation the Convention remarks that the person's wishes should be respected. However, it is hard to imagine that a person's wish to remain stateless should also be respected in view of the fundamental principles on which the two European Conventions rely, that is, the existence of the right to a nationality as linked to the obligation to avoid statelessness 
and the obligation to prevent persons from becoming stateless in State succession situations. Therefore, it should be concluded that once the State has put in place reasonable procedures for granting nationality, the persons concerned should make use of them.

\section{The Decolonisation Process}

Spain, Belgium and the United Kingdom are three States which are not alien to the phenomenon of State succession. Due to their status as former colonial powers, they played a significant role during the decolonisation process. In the road to independence of their colonies and protectorates, provisions dealing with nationality were drafted. In the following sections the focus will be placed on the most recent cases of decolonisation, i.e., colonies and protectorates that achieved independence -or in which territory a replacement of one State by another in the responsibility for the international relations happened-from Spain, Belgium and the United Kingdom after WWII.

The decolonisation process has been treated as a specific sort of State succession. The two Vienna Conventions on State succession devote separated sections to State succession within the context of the decolonisation process. Thus, a direct analogy cannot be drawn from that situation and applied to the scenarios in Catalonia, Flanders and Scotland. However, the reactions of Spain, Belgium and the United Kingdom with regard to nationality issues in the context of decolonisation are helpful in observing certain patterns which will be discussed in this section.

\subsection{Spain}

After WWII, Spain still possessed a few remnant colonies located exclusively on the African continent. Ignoring the Spanish-French protectorate in Morocco, the following section shall address the nationality law related issues that arose in respect of the transfer of Ifni, the independence of Equatorial Guinea and the Spanish abandonment and the double invasion of Western Sahara by Morocco and Mauritania. Before abrogating colonial ties with Spain, one of the common features of those former Spanish territories was their status as Spanish provinces, rather than colonies. This status had important implications for the nationality of the inhabitants of those territories since they were assimilated to Spanish nationals. However, that assimilation did not fully equate to Spanish nationality, but rather they possessed the status of súbditos españoles enjoying Spanish nationality. ${ }^{251}$ Formally, the status of súbdito español meant having the 
same rights and obligations as a Spanish national. ${ }^{252}$ For instance, in the case of the Western Sahara, the súbditos españoles could be elected as members of the Spanish Parliament, hold official Spanish passports, and become civil servants of the Spanish public administration. ${ }^{253}$

\subsubsection{Ifni}

By virtue of the Treaty of Peace and Amity between the Kingdom of Spain and the Kingdom of Morocco (also known as Wad-Ras Treaty) signed in Tétouan on 26 May 1860, Ifni was ceded by Morocco to Spain. ${ }^{254}$ Almost

1 May 2015 to 31 May 2015, Ministry of Justice Bulletin (Boletín del Ministerio de Justicia) Madrid, Ministry of Justice, November 2015, pp. 11-15] refers the situation of Spanish subjects from Equatorial Guinea as follows: "Equatorial Guinean natives never were Spanish nationals but Spanish subjects who benefited from the Spanish nationality and whose personal status changed, for overriding reasons of public international law, with the decolonization process, which created a new State whose essential element, its nationals, was composed by natives of that territory" (English translation GMG). Similar resolutions reaching identical conclusions can be found in relation to Ifni and the Western Sahara. For Ifni, see the DGRN Resolution $3^{\circ}$ of 28 July 2009 [DGRN Resolutions - compilation from 1 June 2009 to 30 September 2009, Ministry of Justice Bulletin (Boletín del Ministerio de Justicia) Madrid, Ministry of Justice, September 2010, pp. 130-131] stating the fact that "those born in the territory of Ifni when it was a Spanish possession (...) were not actual Spanish nationals, only Spanish subjects who benefited from the Spanish nationality" (English translation GMG). For Western Sahara see the DGRN Resolution 92음 31 July 2014 [DGRN Resolutions - compilation from 1 July 2014 to 30 July 2014, Ministry of Justice Bulletin (Boletín del Ministerio de Justicia) Madrid, Ministry of Justice, April 2015, pp. 33-38] stating that "those born in the territory of the Western Sahara when it was a Spanish possession were not actual Spanish nationals but only Spanish subjects who benefited from the Spanish nationality, even if it could be concluded otherwise from certain provisions prior to the abandonment by Spain of that territory" (English translation GMG).

252 See Law 191/1963, 20 December, on the autonomous regime of Equatorial Guinea (Ley 191/1963, de 20 de diciembre, de Bases sobre el regimen autónomo de la Guinea Ecuatorial, BOE, n. 312, 30 December 1963, pp. 18124-18125), provision II: "Native nationals from Fernando Poo and Río Muni have the same rights and duties granted to other Spaniards according to the Fundamental Laws" (English translation GMG).

253 See Law 8/1961, 19 April, on the organisation and the legal regime of the Province of Sahara (Ley8/1961, de 19 de abril, sobre organización y régimen jurídico de la Provincia de Sahara, BOE, n. 95, 21 April 1961, p. 6062), Article 4: "Province of Sahara will enjoy the rights of representation in Parliament and other public bodies corresponding to the Spanish provinces". See also María Isabel Cazorla, La sucesión de estados y sus efectos sobre la nacionalidad de las personas físicas, Servicio de Publicaciones e Intercambio Científico de la Universidad de Málaga (ed.), Málaga, 2001, p. 262.

254 Treaty of Peace and Amity between the Kingdom of Spain and the Kingdom of Morocco [Tratado de paz y Amistad entre los muy poderosos Príncipes S.M. Doña Isabel II, Reina de las Españas, y Sidi-Mohammed, Rey de Marruecos, Fez, Mequinez 
a century after this cession, in 1958, Ifni acquired the status of Spanish province, with a similar status to the Spanish metropolitan provinces. ${ }^{255}$ Only a decade after, in 1969, the retrocession treaty was signed..$^{256}$ Article 3 of that treaty dealt with the consequences of the retrocession for the nationality of the inhabitants of Ifni. ${ }^{257}$ That provision made a clear distinction between, on the one hand, those who acquired Spanish nationality according to one of the grounds of acquisition that Spanish nationality law foresaw in the Spanish Civil Code and, on the other hand, those persons born in the territory of the Ifni and who benefited from Spanish nationality (que se hayan beneficiado de la nacionalidad española).

The first group of persons, i.e., Spanish nationals who acquired that nationality according to the rules on acquisition of nationality of the Spanish Civil Code, maintained Spanish nationality in any case upon the retrocession. Thus, the territorial change did not affect the nationality status of these nationals, including those "españoles de origen" who

\& c.], Gaceta de Madrid, n. 157, 5 April 1860, p. 1, Article 8. The Spanish version of that provision reads as follow: "S.M. Marroquí se oblige a conceder a perpetuidad a S.M. Católica en la coste del Océano junto a Santa Cruz la pequeña el territorio suficiente para la formación de un establecimiento de pesquería como el que España tuvo allí antiguamente [...]". Notice that Santa Cruz de la Mar Pequeña was the Spanish name given to Ifni in times of the Catholic Kings. See also Manuel Lozano Serralta, La nacionalidad en los territorios dependientes, Madrid, Consejo Superior de Investigaciones Científicas, 1955, p. 77.

255 Decree, January 10, by which the general government of the Spanish West Africa is rearranged (Decreto de 10 de enero de 1958 por el que se reorganiza el gobierno general del África occidental española), BOE, n. 12, 14 January 1958, p. 87. See also María Isabel Cazorla, La sucesión de estados y sus efectos sobre la nacionalidad de las personas físicas, Servicio de Publicaciones e Intercambio Científico de la Universidad de Málaga (ed.), Málaga, 2001, p. 260.

256 Ratification instrument of the Treaty providing the retrocession by the Spanish State to the Kingdom of Morocco of the territory previously ceded by the latter according to Article 8 of the Treaty of Tétouan [Instrumento de Ratificación del Tratado por el que el Estado Español retrocede al Reino de Marruecos el territorio que éste le había previamente cedido en aplicación del artículo 8 del Tratado de Tetuán de 26 de abril de 1860, firmado en Fez el día 4 de enero de 1969], BOE, n. 134, 5 June 1969, pp. 8805-8808.

257 The Spanish version of Article 3 reads as follows: "Con la excepción de los que hayan adquirido la nacionalidad española por alguno de los modos de adquisición establecidos en el Código Civil español, que la conservarán en todo caso, todas las personas nacidas en el territorio y que se hayan beneficiado de la nacionalidad española hasta la fecha de la cesión podrán optar por esta nacionalidad efectuando una declaración de opción ante las autoridades españolas competentes en el plazo de tres meses a contar de dicha fecha.

La nacionalidad Española con la plenitud de los derechos y obligaciones, una vez inscrita en el registro español correspondiente, será reconocida como tal en todos sus efectos por las autoridades marroquíes". 
acquired the nationality from their parents via ius sanguinis.

As regards the second group, that is, persons born on the territory of Ifni and who enjoyed the status of súbdito español, they became Moroccan nationals at the moment of the cession of the territory to Morocco unless they expressly opted for Spanish nationality. That option right had to be exercised within three months after the date of retrocession. This option right was also subject to certain conditions laid down in Article 1 of the protocol annexed to the retrocession treaty, i.e. the option for the Spanish nationality had to be inscribed in the Spanish registry, and the renunciation of the previous Moroccan nationality was an essential requirement that had to be done expressly "in a written statement before the competent Moroccan authorities which will issue in favour of the applicant a certificate attesting that such a renunciation has been done". ${ }^{258}$ In practice, compliance with these requirements was virtually impossible, ${ }^{259}$ given the restrictive time period provided in Article 3 of the retrocession treaty to exercise the right to opt for Spanish nationality. ${ }^{260}$

A clear conclusion can be drawn from the retrocession treaty regarding the effects of this kind of State succession for the nationality of the inhabitants of Ifni: Spanish nationals could retain their nationality without further requirements but those Spanish subjects who enjoyed the benefit of Spanish nationality needed to opt for Spanish nationality which, in practice, turned to be almost impossible.

258 Translation by the author. Article 1 of the Protocol annexed to the ratification instrument of the Treaty providing the retrocession by the Spanish State to the Kingdom of Morocco of the territory previously ceded by the latter according to Article 8 of the Treaty of Tétouan [Protocolo anejo al Instrumento de Ratificación del Tratado por el que el Estado Español retrocede al Reino de Marruecos el territorio que éste le había previamente cedido en aplicación del artículo 8 del Tratado de Tetuán de 26 de abril de 1860, firmado en Fez el día 4 de enero de 1969], BOE, n. 134, 5 June 1969, p. 8806. The Spanish version of that provision provides that: "Para la inscripción en el registro español correspondiente de la nacionalidad de las personas que hagan uso de la opción prevista en el artículo 3 del Tratado, será considerada indispensable una renuncia previa y expresa de derechos a la nacionalidad marroquí. Esta renuncia deberá ser hecha por escrito ante las autoridades marroquíes competentes, que extenderán en favor del interesado un certificado fehaciente de que esta diligencia ha sido realizada. Los efectos de esta renuncia serán plenamente reconocidos una vez inscrita la opción en el registro español correspondiente".

259 On the procedural requirement to exercise the right to opt as provided by Article 3 of the retrocession treaty, see: María Isabel Cazorla, La sucesión de estados y sus efectos sobre la nacionalidad de las personas físicas, Servicio de Publicaciones e Intercambio Científico de la Universidad de Málaga (ed.), Málaga, 2001, p. 266.

260 RDGRN 19 mayo de 1972 acknowledges the importance of the three months period to opt for the Spanish nationality and, at the same time, the difficult to comply with this in practice. 


\title{
6.1.2 Equatorial Guinea
}

Spanish Guinea was administered by Spain from 1877 to 1968. Similar to the Ifni situation, in 1959, the territory of Equatorial Guinea acquired the status of a Spanish province (the territory was divided into two provinces: Río Muni and Fernando Poo). ${ }^{261}$ In 1963, a certain degree of autonomy was conferred upon the province, ${ }^{262}$ which ultimately led to independence in $1968 .^{263}$ It is remarkable that the question of nationality was not addressed upon the independence of Equatorial Guinea. However, according to transitional provision n. 1 of the Equatorial Guinean Constitution of 1968:

\begin{abstract}
"Regardless of what the future Nationality Act will provide, persons of African descent who were born in Equatorial Guinea and their children, even if the latter are born outside Guinea, shall be deemed Guinean nationals provided that in either cases they have been in possession of the Guinean nationality". 264
\end{abstract}

Thus, Equatorial Guinean nationality was to be enjoyed by persons born in the territory of that country and their children, insofar as they were of "African descent". Almost 10 years later, in 1977, Spanish Royal Decree $2987 / 1977^{265}$ granted Spanish nationality to certain groups of Equatorial Guineans via "carta de naturaleza", i.e., discretionary naturalisation granted by Royal Decree, when special circumstances allowed for it. That Royal Decree considered that special circumstances occurred in the case of Equatorial Guineans residing in Spain at the time of publication of the Royal Decree and who enjoyed the status of Spanish subject according to Decree 1885/1964. ${ }^{266}$ Article 2 provided for a period of one year following

261 See Law 46/1959, 30 July, on the organisation and legal regime of the African Provinces [Ley 46/1959, de 30 de Julio, sobre organización y regimen jurídico de las Provincias Africanas], BOE, n. 182, 31 July 1959, pp. 10370-10371.

262 See Law 191/1963, 20 December, on the autonomous regime of Equatorial Guinea (Ley 191/1963, de 20 de diciembre, de Bases sobre el regimen autónomo de la Guinea Ecuatorial), BOE, n. 312, 30 December 1963, pp. 18124-18125.

263 Decree 2467/1968, 9 October, granting independence to Equatorial Guinea (Decreto 2467/1968, de 9 de octubre, por el que se concede la independencia a Guinea Ecuatorial), BOE n. 245, 11 Ocotber 1968, p. 14442.

264 Translation by the author. The Spanish version reads as follows: "Con independencia de lo que en su día disponga la Ley de Nacionalidad, se considerarán nacionales guineanos las personas de ascendencia africana que hayan nacido en Guinea Ecuatorial y sus hijos, aunque hayan nacido fuera de ella, siempre que en uno y otro caso vengan poseyendo como tales la nacionalidad guineana".

265 Royal Decree 2987/1977, 28 October, granting Spanish nationality to certain Equatorial Guineans (Real Decreto 2987/1977, de 28 de octubre, sobre concesión de la nacionalidad española a determinados guineanos), BOE, n. 282, 25 November 1977, p. 25874.

266 See Decree 1885 /1964, 3 July, adopting the act on the autonomous regime of 
the publication in the Spanish Official Gazette to initiate the procedure necessary to obtain Spanish nationality via "carta de naturaleza". Similarly, those Equatorial Guineans who, after independence, were enlisted in the Spanish military or were civil servants or public employees kept the status of Spanish subjects. ${ }^{267}$

This Royal Decree, although connected to the former colony, was not stricto sensu connected to the independence of that territory. Its aim was to address the situation of thousands of Equatorial Guinean nationals living in Spain who could not return to Equatorial Guinea for political reasons. ${ }^{268}$

Nowadays, the historical association between Equatorial Guinea and Spain is reflected in the rules on acquisition of Spanish nationality by residence. Equatorial Guineans have a privileged position when acquiring Spanish nationality based on residence, since only two years of residence are required to be naturalised, in comparison to the general requirement of ten years. ${ }^{269}$ Equatorial Guineans alongside nationals of Latin American countries, Andorra, Philippines, Portugal and Sephardim, also enjoy this privileged position in the naturalisation process. ${ }^{270}$

\subsubsection{Western Sahara}

Western Sahara was ceded by Portugal to the Castile Crown in 1509, 271

Equatorial Guinea (Decreto 1885/1964, de 3 de Julio, por el el que se aprueba la ley articulada sobre regimen autonómico de la Guinea Ecuatorial), BOE, n. 161, 6 July 1964, pp. 8679-8685.

267 First Additional Provision of the Royal Decree 2987/1977, 28 October, granting Spanish nationality to certain Equatorial Guineans (Real Decreto 2987/1977, de 28 de octubre, sobre concesión de la nacionalidad española a determinados guineanos), BOE, n. 282, 25 November 1977, p. 25874. That Additional Provision reads as follows: "Sin perjuicio de que, en su interés, puedan formular la declaración a que se refiere el artículo segundo, se reconoce a todos los efectos que los guineanos que, tras el 12 de octubre de 1968, hubiesen estado al servicio de las armas españolas o ejercido cargo o empleo público de España como súbditos españoles, optaron por seguir teniendo esta última condición".

268 María Isabel Cazorla, La sucesión de estados y sus efectos sobre la nacionalidad de las personas físicas, Servicio de Publicaciones e Intercambio Científico de la Universidad de Málaga (ed.), Málaga, 2001, p. 268.

269 Código Civil, Royal Decree 24 July 1889, Madrid Official Gazette (Gaceta de Madrid) No. 206, 25 July 1889, pp. 249-259, Article 22.

270 Código Civil, Royal Decree 24 July 1889, Madrid Official Gazette (Gaceta de Madrid) No. 206, 25 July 1889, pp. 249-259, Article 22. Notice that neither Morroccan nationals from Ifni nor Sahrawi people can benefit from that fast track naturalisation based on residence.

271 Capitulation of Cintra or Capitulation of Sintra, 18 September 1509. The kings of Portugal, Manuel I, and Castile, Juana I, signed this treaty. Its object was clarifying 
but until 1884 there was no active occupation by Spain. ${ }^{272}$ Similarly to Ifni and Equatorial Guinea, Western Sahara acquired the status of a Spanish province in $1958^{273}$ and its inhabitants acquired the status of Spanish subjects. ${ }^{274}$

The decolonisation of Western Sahara was especially difficult. A combination of the sovereignty claims over that territory made by Morocco and Mauritania, the period of uncertainty around the last days of the Spanish dictator and the active role played by the UN led to a rather complex and incomplete decolonisation process. In 1965, the UN General Assembly issued its first Resolution on the question of the "Spanish Sahara", in which the Spanish Government was requested to take "all necessary measures for the liberation of the (...) Spanish Sahara from colonial domination". ${ }^{275}$ One year later, another UN General Assembly Resolution requested that a referendum be initiated by Spain on self-determination, and invited Spain to

"determine at the earliest possible date, in conformity with the aspirations of the indigenous people of Spanish Sahara and in consultation with the Governments of Mauritania and Morocco and any other interested party, the procedures for the holding of a referendum under United Nations auspices with a view to enabling the indigenous population of the Territory to exercise freely its right to self-determination". ${ }^{276}$

the boundaries between the areas of influence of both kingdoms in the North of Africa. See Manuel Lozano Serralta, La nacionalidad en los territorios dependientes, Madrid, Consejo Superior de Investigaciones Científicas, 1955, p. 77.

272 According to the ICJ Western Sahara Advisory Opinion "the time of colonization by Spain may be considered as the period beginning in 1884, when Spain proclaimed a protectorate over the Rio de Oro. It is true that Spain has mentioned certain earlier acts of alleged display of Spanish sovereignty in the fifteenth and sixteenth centuries. But it has explained that it did so only to enlighten the Court as to the remote antecedents of the Spanish presence on the West-African Coast, and not to prove any continuity between those acts and "the time of colonization by Spain", which it conceded should be regarded as beginning in 1884". Western Sahara, Advisoty Opinion, I.C.J. Reports 1975, p. 12.

273 Decree of 10 January 1958 by which the general government of the Spanish West Africa is rearranged (Decreto de 10 de enero de 1958 por el que se reorganiza el gobierno general del África occidental española) BOE, n. 12, 14 January 1958, p. 87.

274 Law 8/1961, 19 April, on the organisation and the legal regime of the Province of Sahara (Ley 8/1961, de 19 de abril, sobre organización y régimen jurídico de la Provincia de Sahara, BOE, n. 95, 21 April 1961, p. 6062).

275 Resolution 2072 (XX) of 16 December 1965, Question of Ifni and Spanish Sahara, Official Records of the General Assembly, Twentieth Session, Supplement No. 14 (A/6160).

276 Resolution 2229 (XXI) of 20 December 1966, Question of Ifni and Spanish Sahara, Official Records of the General Assembly, Twenty-first Session, Supplement No. 16 (A/6623). 
This demand from the UN General Assembly was repeatedly laboured from 1967 to $1973 .{ }^{277}$ Meanwhile, in 1973, the Popular Front for the Liberation of Saguia el-Hamra and Río de Oro (POLISARIO Front) was created with the express intention of forcing an end to Spanish colonisation and achieving the independence of Western Sahara. ${ }^{278}$ By the end of 1973, the Spanish Government's position towards the decolonisation of Western Sahara was to accelerate the decolonisation of that province in line with the demands of the UN General Assembly. In 1974 the Spanish Government sent a note to UN Secretary General, Kurt Waldheim, announcing a referendum in the territory of the Spanish Sahara which would take place within the first six months of 1975 under the auspices of the UN. ${ }^{279}$

However, when Spain was preparing to implement the process of decolonisation of the Sahara, Morocco and Mauritania raised claims of sovereignty over that territory. As a result of pressure from Morocco and Mauritania, the UN General Assembly requested, on 13 December 1974, the ICJ to give an Advisory Opinion on the following questions:

\section{"Was Western Sahara (Río de Oro and Sakiet El Hamra) at the time of colonisation by Spain a territory belonging to no one (terra nullius)?}

If the answer to the first question is in the negative, what were the legal ties between this territory and the Kingdom of Morocco and the Mauritanian entity?". 280

277 See Resolution 2354 (XXII) of 19 December 1967, Question of Ifni and Spanish Sahara, Official Records of the General Assembly, Twenty-second Session, Supplement No. 16 (A/7013); Resolution 2428 (XXIII) of 18 December 1968, Question of Ifni and Spanish Sahara, Official Records of the General Assembly, Twenty-third Session, Supplement No. 18(A/7419); Resolution 2591 (XXIV) of 16 December 1969, Question of Spanish Sahara, Official Records of the General Assembly, Twenty-forth Session, Supplement No. 30 (A/7896); Resolution 2711 (XXV) of 14 December 1970, Question of Spanish Sahara, Official Records of the General Assembly, Twenty-fifth Session, Supplement No. 28 (A/8248); Resolution 2983 (XXVII) of 14 December 1972, Question of Spanish Sahara, Official Records of the General Assembly, Twenty-seven Session, Supplement No. 30 (A/8955); and Resolution 3162 (XXVIII) of 14 December 1973, Question of Spanish Sahara, Official Records of the General Assembly, Twenty-eight Session, Supplement No. 30 (A/9417).

278 Rafael Viñes Taberna, Notas Históricas sobre el Sáhara Occidental, Ediciones del Cabildo de Gran Canaria, Las Palmas de Gran Canaria, 2003, p. 113.

279 Rafael Viñes Taberna, Notas Históricas sobre el Sáhara Occidental, Ediciones del Cabildo de Gran Canaria, Las Palmas de Gran Canaria, 2003, p. 114. See also Oriol Casanovas, Ángel J. Rodrigo, Casos y textos de Derecho Internacional Público, Tecnos (ed.), Madrid, $6^{\text {th }}$ edition, 2010, pp. 290-291.

280 Resolution 3292 (XXIX) of 13 December 1974, Question of Ifni and Spanish Sahara, Official Records of the General Assembly, Twenty-first Session, Supplement No. 16 (A/6623). 
At the same time that the UN General Assembly requested this Advisory Opinion, it urged Spain to postpone the referendum until it

"decides on the policy to be followed in order to accelerate the decolonisation process in the Territory, in accordance with resolution 1514 (XV), in the best possible conditions, in the light of the advisory opinion to be given by the International Court of Justice". ${ }^{281}$

The ICJ delivered its opinion on 16 October 1975. In response to the first question, the Court determined that the Western Sahara was not terra nullius at the time of the Spanish colonisation. ${ }^{282}$ As regards the second question, although the ICJ found that there were certain legal ties between the Sultan of Morocco and certain tribes of the territory and despite the existence of certain rights, including rights to land, between the territory and Mauritanian entity, there were no ties of territorial sovereignty between Western Sahara and the Kingdom of Morocco or Mauritania. Thus, the Court did not find "legal ties of such nature as might affect the application of resolution 1514 (XV) in the decolonisation of Western Sahara and, in particular, of the principle of self-determination through the free and genuine expression of the will of the peoples of the Territory". ${ }^{283}$

Morocco then launched a mass mobilisation, known as the "Green March", entering the territory of the Sahara. On 14 November 1975, while the dictator Franco was dying and Spain was entering a situation of immense tension and uncertainty, the Declaration of Principles on Western Sahara were signed between the Spanish Government, Morocco and Mauritania. ${ }^{284}$ In that Declaration, Spain, as the administering Power of the Territory, transferred the powers and responsibilities relating to the Western Sahara to a temporary tripartite administration. The objective of the Spanish Government was clear from the first point of the Declaration:

"Spain confirms its resolve, repeatedly stated in the United Nations, to decolonize the Territory of Western Sahara by terminating the responsibilities and powers which it possesses over that Territory as administering Power". ${ }^{285}$

281 Resolution 3292 (XXIX) of 13 December 1974, Question of Ifni and Spanish Sahara, Official Records of the General Assembly, Twenty-first Session, Supplement No. 16 (A/6623).

282 Western Sahara, Advisory Opinion, ICJ GL No 61, [1975] ICJ Rep 12, ICGJ 214 (ICJ 1975), 16th October 1975, para. 83.

283 Western Sahara, Advisory Opinion, ICJ GL No 61, [1975] ICJ Rep 12, ICGJ 214 (ICJ 1975), 16th October 1975, para. 162.

284 Declaración de principios entre España, Marruecos y Mauritania sobre el Sáhara Occidental, 14 November 1975, UNTS vol. 988, p. 258.

285 Emphasis added GMG. Declaración de principios entre España, Marruecos y 
Furthermore, according to point 2 of the Declaration, it was stipulated that the Spanish presence in the Western Sahara "will be completed by February 28, 1976 at the latest".

Five days after the Declaration of Principles on Western Sahara was concluded, Law 40/1975 on the decolonisation of the Sahara was passed. ${ }^{286}$ Contained within this law was one sole provision that simply authorised the Spanish Government to perform the acts and adopt the necessary measures to carry out the decolonisation of the Sahara, and to protect Spanish interests. The most interesting point of the law is to be found in the explanatory memorandum. In this explanatory memorandum, Spain not only transferred its powers vis-à-vis the Western Sahara, but Spain also denied that the Spanish Sahara was ever part of the Spanish territory. ${ }^{287}$ This new attitude towards the Western Sahara was reflected in the nationality legislation enacted by Spain after its withdrawal from that territory, in which a distinction was made between Sahrawi people residing in Spanish territory and Sahrawi people residing outside Spanish territory. ${ }^{288}$

In December 1975, two new Resolutions were adopted by the UN General Assembly: Resolutions 3458-A (XXX) and 3458-B (XXX) on the question of Spanish Sahara. ${ }^{289}$ In the first Resolution, which makes no reference to the Declaration of Principles on Western Sahara, the UN General Assembly

Mauritania sobre el Sáhara Occidental, 14 November 1975, UNTS vol. 988, p. 258, point 1 . The Spanish original text reads as follows: "España ratifica su resolución, reiteradamente manifestada ante la ONU, de descolonizar el territorio del Sahara occidental poniendo término a las responsabilidades y poderes que tiene sobre dicho territorio como Potencia Administradora" (English translation GMG).

286 Law 40/1975, 19 November, on the decolonisation of the Sahara (Ley 40/1975, de 19 de noviembre, sobre descolonización del Sáhara), BOE, n. 278, 20 November 1975, p. 2434.

287 The explanatory memorandum notes that "The Spanish State has been exercising, as administering Power, full of competencies and powers on the non-autonomous territory of the Sahara, which for some years has been subjected in certain aspects of their administration to a particular regime with analogies to a province but has never been part of the national territory" (English translation GMG). The original Spanish text reads as follows: "El Estado Español ha venido ejerciendo, como Potencia administradora, plenitud de competencias y facultades sobre el territorio no autónomo del Sahara, que durante algunos años ha estado sometido en ciertos aspectos de su administración a un régimen peculiar con analogías al provincial y que nunca ha formado parte del territorio nacional".

288 See remarks on the Royal Decree 2258/1976, 10 August, on the right to opt for Spanish nationality by Sahrawi people at the end of this section.

289 Resolutions 3458 A-B (XXX) of 10 December 1975, Question of Spanish Sahara, Official Records of the General Assembly, Thirtieth Session, Supplement No. 34 (A/10427). 
requested the Spanish Government "as the administering Power" and in accordance with the ICJ and the conclusions of the Visiting Mission ${ }^{290}$ "to take immediately all necessary measures (...) so that all Saharans originating in the Territory may exercise fully and freely, under United Nation supervision, their inalienable right to self-determination". However, the second Resolution did make reference to the tripartite agreement concluded by Mauritania, Morocco and Spain and requested the parties of the agreement to "take all steps to ensure that all the Saharan population originating in the Territory will be able to exercise their inalienable right to self-determination through free consultations organized with the assistance of a representative of the United Nations appointed by the Secretary-General". Thus, the same request was made to both, Spain and the temporary tripartite administration.

The next step taken by Spain was the complete withdrawal of its presence in the territory of Sahara. On a letter dated 26 February 1976 addressed to the UN Secretary-General by the Permanent Representative of Spain to the $\mathrm{UN},{ }^{291}$ Spain officially abandoned the Sahara by stating that "the Spanish Government, as of today, definitively terminates its presence in the Territory of the Sahara". The letter made reference to the Spanish efforts to achieve the

\begin{abstract}
"speedy decolonization under peaceful conditions and with respect for the views of the population of the Territory. The persistence of circumstances beyond its control has made it impossible thus far to organize the popular consultation provided for in the agreements of 14 November 1975 and in resolution 3458 B (XXX)". ${ }^{292}$
\end{abstract}

The sentence "circumstances beyond its control" referred to the military escalation between the POLISARIO Front, Moroccan and Mauritanian

290 During May and June 1975, a delegation of the UN Decolonisation Committee visited the Western Sahara, Morocco, Mauritania, Algeria and Spain. The UN Visiting Mission to Spanish Sahara issued a report requesting the UN General Assembly to enable "all Saharans originating in the Territory to decide on their future in complete freedom and in an atmosphere of peace and security". Report of the United Nations Visiting Mission to Spanish Sahara, Official Records of the General Assembly, Thirtieth Session, Supplement No. 23 (A/10023/Rev. I).

291 Letter dated 26 February 1976 from the Permanent Representative of Spain to the United Nations addressed to the Secretary-General, Official Records of the Security Council, Thirty-first Year, Supplement for January, February and March 1976, (A/31/56-S/11997).

${ }^{292}$ Letter dated 26 February 1976 from the Permanent Representative of Spain to the United Nations addressed to the Secretary-General, Official Records of the Security Council, Thirty-first Year, Supplement for January, February and March 1976, (A/31/56-S/11997). 
forces, that led to the establishment of the first refugee camps in Tindouf (Algeria).

The letter ended with the two following remarks:

"(a) Spain considers itself henceforth exempt from any responsibility of an international nature in connexion with the administration of the said Territory, in view of the cessation of its participation in the temporary administration established for the Territory:,

(b) The decolonization of Western Sahara will reach its climax when the views of the Saharan population have been validly expressed". ${ }^{293}$

By doing this Spain left, on the one had, freeway to Morocco and Mauritania to occupy the territory of the Western Sahara and, on the other hand, a decolonisation process that is still incomplete. ${ }^{294}$

However, the fact that the decolonisation process was not concluded was no obstacle for the Spanish Government enacting, in August 1976, Royal Decree 2258/1976 on the right to opt for Spanish nationality for Sahrawi people ${ }^{295}$ which had the effect of laying down the conditions to exercise such a right. According to Article 1 of the Royal Decree, Sahrawi people residing on Spanish territory and holding Spanish general identity documentation or, residing outside Spanish territory and holding a bilingual national identity document issued by Spanish authorities, a Spanish passport or being included in the registries of the Spanish Foreign representations, could opt for Spanish nationality. The option for Spanish nationality was limited to a period of one year following the entry into force of the Royal Decree. The option had to be exercised before a judge in charge of the civil

293 Letter dated 26 February 1976 from the Permanent Representative of Spain to the United Nations addressed to the Secretary-General, Official Records of the Security Council, Thirty-first Year, Supplement for January, February and March 1976, (A/31/56-S/11997).

294 The day after the official withdrawal of Spain from the Western Sahara, the POLISARIO Front proclaimed the Saharawi Arab Democratic Republic. Although the UN Security Council established by Resolution S/1991/690 the United Nations Mission for the Referendum in Western Sahara (MINURSO) to implement the Settlement Plan, monitor the cease-fire, identify eligible voters for participation in the referendum, and create the conditions and modalities for the supervision and conduct of the referendum- the Sahrawi people have not yet had the chance to exercise their inalienable right to self-determination.

295 Royal Decree 2258/1976, 10 August, on the right to opt for Spanish nationality by Sahrawi people (Real Decreto 2258/1976, de 10 de agosto, sobre opción de la nacionalidad española por parte de los naturales del Sahara), BOE, n. 233, 28 September 1976, p. 18904. 
registrar of the place of residence in Spain or before a Spanish consul of the place of residence if outside the Spanish territory.

The entry into force of this Royal Decree meant, in practice, that most of the inhabitants of the Western Sahara territory who did not hold Spanish nationality could not exercise that option right, not only due to the short time period provided but especially due to the armed conflict in the area. Furthermore, the Sahrawi people ${ }^{296}$ that did not exercise their right to opt for Spanish nationality and did not want to acquire the nationality of the occupying forces of Morocco or Mauritania became, in the majority of cases, de facto stateless.

Nowadays, Sahrawi people do not enjoy a privileged position to access Spanish nationality, which differentiates them from nationals of other former Spanish colonies. ${ }^{297}$ Furthermore, numerous requests to acquire Spanish nationality via declaration and based on the "continued possession and use of Spanish nationality for ten years" 298 have been submitted. The Dirección General de Registros y Notariado (DGRN) had always dismissed these requests based on the fact those born in the territory of the Western Sahara when it was a Spanish possession were not actually Spanish nationals but only Spanish subjects who benefited from Spanish nationality, even if it could be concluded otherwise from certain provisions prior to the abandonment by Spain of that territory. ${ }^{299}$ Furthermore, that benefit of Spanish nationality was meant to cease after one year provided for in the Royal Decree 2258/1976. This situation was partially altered by a decision of the Supreme Court of 28 October 1998, ${ }^{300}$ in which the applicant was granted the consolidation of Spanish nationality. The Court highlighted the inconsistent and piecemeal nature of the legislation adopted in relation to Western Sahara: at first it was considered a colony; followed by a period in which the Sahara was equated to a Spanish province; and finally it entered the phase of decolonisation taking the form of self-determination, although

296 Who until the official withdrawal of Spain enjoyed the status of súbdito español.

297 This fact was recently highlighted during the parliamentary debates on the legislative initiative to grant Spanish nationality to the Sephardim. See Boletín Oficial de las Cortes Generales, Senado, X legislatura, No. 509, 24 April 2015, pp. 6- 13.

298 Código Civil, Royal Decree 24 July 1889, Madrid Official Gazette (Gaceta de Madrid) No. 206, 25 July 1889, pp. 249-259, Article 18. This provision stipulates that the possession and continued use of Spanish nationality for ten years, in good faith and based on a title registered at the Civil Registry, consolidates the nationality, even if the title that originated it has been declared void.

299 DGRN Resolution 92ㅇ of 31 July 2014 [DGRN Resolutions - compilation from 1 July 2014 to 30 July 2014, Ministry of Justice Bulletin (Boletín del Ministerio de Justicia) Madrid, Ministry of Justice, April 2015, pp. 33-38].

300 STS 6268/1998, Section 1, 28 October 1998. 
there was also the abandonment of the territory by Spain and military occupation by another State. ${ }^{301}$ The Court made an important remark on the nationality of the Sahrawi people. It considered that the Sahrawi people held Spanish nationality during the Spanish colonisation period "as is evident, according to the general rules of the law of nationality, that the natives of the colonial territory did not possess another nationality than the one of the colonising State since there was not other State organization". ${ }^{302}$ As stated by the Court, a different question to be considered was the existence of different grades of material and formal assimilation, between the various legal statutes of the population, which, in practice meant that the colonising States imposed restrictions on the civil status of the colonised population. ${ }^{303}$

After the ruling of the Supreme Court, the DGRN has recognised the consolidation of Spanish nationality by Sahrawi applicants when the conditions laid down in the decision are met, i.e. registration in the Spanish Civil Register (in this case, being registered as súbdito español); evidence of the possession and use of Spanish nationality for ten years (being sufficient the possession of valid Spanish documentation during such period); and the de facto impossibility to exercise the option granted by Royal Decree 2258/1976.

\subsection{Belgium}

From the three States under analysis, the role of Belgium as a colonial power was not that significant when compared with Spain and, especially, with the United Kingdom. The last two Belgian "colonies" were Congo and Ruanda and Burundi.

In 1884 and 1885 the Berlin Conference took place on the position of Congo. In February 1885 a Treaty ${ }^{304}$ was concluded and on 15 November 1884, the État indépendant du Congo (Congo Free State) was proclaimed with King Leopold II of Belgium as the sovereign ruler. In his testament of 2 August 1889, the King declared that the territory of Congo would go to Belgium after his death. Briefly before he died in 1909, the King transferred the territory of Congo to Belgium on 15 November 1908. Since that date, Congo was administered as a Belgian colony.

301 STS 6268/1998, Section 1, 28 October 1998, third paragraph of the assessment by the Court (fundamento de derecho tercero) (English translation GMG).

302 STS 6268/1998, Section 1, 28 October 1998, fifth paragraph of the assessment by the Court (fundamento de derecho quinto) (English translation GMG).

303 STS 6268/1998, Section 1, 28 October 1998, fifth paragraph of the assessment by the Court (fundamento de derecho quinto) (English translation GMG).

304 See on the background of the Treaty of Berlin A.M.D. Sweerts de Landas Wyborgh, Het Berlijnsche Tractaat van 26 February 1885, Mouton \& Co, 's-Gravenhage, 1886. 
After the riots of 4 January 1959, Congolese and Belgian representatives met in Brussels to discuss the conditions of Congolese independence during round table meetings. The Congolese Round Table Conference (Round Table Conference of Brussels or Conférence de la Table ronde belgocongolaise) was held in Brussels from 20 January 1960 until 20 February 1960 and again from 26 April 1960 until 16 May 1960 and consisted of representatives of Congolese political class leaders and Belgian political and business leaders.

The round table meetings led to the adoption of sixteen resolutions on the future of the Belgian Congo and its institutional reforms. With broad consensus achieved, the date for Congolese independence was to be 30 June 1960. At these meetings, there was no recorded discussion on the nationality related issues of Congolese independence.

The first legislation related to post-independence Congolese nationality was passed in $1961,{ }^{305}$ whereas the Congolese Constitution of $1964^{306}$ referred to the attribution of Congolese nationality from 30 June 1960 to any person whose ascendants are or have been a member of a tribe established in the territory of the Congo before 18 October 1908. However, if those persons had a foreign nationality on the date of entry into force of the Constitution, the acquisition of Congolese nationality was subject to the condition of making a declaration in favour of Congolese nationality if that declaration had a consequence that the person would lose the previous nationality ${ }^{307}$ A period of twelve months from the date of entry into force of the Constitution was established in order to make that declaration if the person concerned was at least 21 years of age ${ }^{308}$ at that time.

It must be noted that both States, Belgium and Congo, were, at that time,

305 Loi No. 35-61 du 20 juin 1961 portant Code de la nationalité congolaise.

306 Constitution de la République Démocratique du Congo du 1 Aout 1964 Cf. Moniteur Congolais ( 5 année), numéro spécial du 1 août 1964.

307 Article 6, Congolese Constitution 1964. The French version reads as follows: "Il existe une seule nationalité congolaise. Elle est attribuée, à la date du 30 juin 1960, à toute personne dont un des ascendants est ou a été membre d'une tribu ou d'une partie de tribu établie sur le territoire du Congo avant le 18 octobre 1908. Toutefois, celles des personnes visées à l'alinéa 2 du présent article qui possèdent une nationalité étrangère à la date de l'entrée en vigueur de la présente Constitution, n'acquièrent la nationalité congolaise que si elles réclament par une déclaration faite dans la forme déterminée par la loi nationale et que si, du fait de cette déclaration, elles perdent la nationalité étrangère. Elles devront faire la déclaration dans le délai de douze mois à compter de la date d'entrée en vigueur de la présente Constitution si elles sont âgées de 21 ans au moins à cette date; si elles ne sont pas âgées de 21 ans, elles devront faire la déclaration dans le délai de douze mois à compter du jour où elles auront atteint cet âge".

308 Which was at that time the age of majority in both Congo and Belgium. 
opposed to dual nationality. Consequently the acquisition of Congolese nationality meant that Belgian nationality was lost and vice versa. ${ }^{309}$

The Belgian legislature reacted unilaterally to the independence of Congo with a modification of the Belgian Nationality Act. ${ }^{310}$ The Bill was submitted to the Belgian Senate on 15 June 1961 and adopted by the Senate on 19 July 1961. The Chamber of Representatives, however, needed considerably more time and ultimately adopted the Bill on 7 December 1961. The Act was signed by the King on 22 December $1961 .^{311}$ The Act dealt not only with the nationality law consequences of the independence of Congo, but also with the (at that time still future) independence of Rwanda and Burundi.

From 1890 Rwanda and Burundi were under German colonial occupation as part of German East Africa (Deutsch Ost Afrika). In 1916 during World War I these territories were occupied by Belgium. In 1920 the League of Nations transferred them to Belgium as mandate territories. After World War II, they ascertained the status of UN trust territories. Both territories became independent on 1 July 1962.

Firstly, the amended Belgian Nationality Act removed all references to the Congo. Secondly, a temporary provision was inserted to the Nationality Act, ${ }^{312}$ which equated with the residence in Belgium as required for the acquisition of Belgian nationality by naturalisation or the recovery of Belgian nationality the ordinary residence in Belgian Congo, or in the territories of Rwanda and Burundi, during the Belgian administration. ${ }^{313}$

309 Maurice Verstraete, "Le cumul des nationalités belge et congolais est-il possible?", Journal de tribunaux d'outre-mer, 1960, p. 64. Compare as well the remarkable proposal of Maurice Verstraete, in La Nationalité Congolaise, Académie royale des Sciences coloniales, Vol. XX, part 3, Brussels, 1959.

310 See on the nationality status before independence Robert Standaert, La Nationalité Belge, Balsacq, Luttre, 1934, pp. 237-240. See also Charles-Louis Closset, Traité pratique de la nationalité Belge, Bruylant, Brussels, 1970, pp. 47-48; Horst-Alex Schmidt, Staatsangehörigkeitswechsel bei Staatensukzessionen, dissertation, Kiel, 1966, p. 63.

311 Loi relative à l'acquisition ou au recouvrement de la nationalité belge par les étrangers nés ou domiciliés sur le territoire de la République du Congo ou par les Congolais ayant eu en Belgique leur résidence habituelle/ Wet betreffende de verwerving of herkrijging van de Belgische nationaliteit door de buitenlanders die geboren zijn of hun woonplaats hebben op het grondgebied van de Republiek Congo of door de Congolezen die hun gewone verblijfplaats in België hebben gehad, Moniteur belge/ Belgisch Staatsblad, 8 January 1962, p. 154.

312 Article 2 of the Act of 22 December 1961.

313 "Demeure assimilée à la résidence en territoire belge pour l'acquisition ou recouvrement de la nationalité belge [...] la résidence habituelle au Congo belge ou 
Moreover, habitual residence in these territories for the three years after the independence was assimilated to residence in Belgium, provided that the person involved already had their residence there before independence or that residence follows on a residence in Belgium. ${ }^{314}$ However, the advantage of these equations only applied on the condition that the persons involved transferred their ordinary residence to Belgium within three years. ${ }^{315}$ These rules had as their goal the facilitation of the acquisition or recovery of Belgian nationality of persons who had to leave the territories of Congo, Rwanda and Burundi due to their independence and did not possess Belgian nationality before or lost this nationality as a consequence of the independence process.

\subsection{The United Kingdom}

After WWII, more than 50 territories were listed by the General Assembly as Non-Self-Governing in which the administering Power was the United Kingdom. ${ }^{316}$ The role of the United Kingdom as the dominant colonial power had an undeniable impact on its nationality legislation. Laurie

dans les territoires du Ruanda et de l'Urundi pendant l'administration belge"/ "Blijft gelijkgesteld met de verblijfplaats op Belgisch grondgebied wat betreft de verwerving of de herkrijging van de Belgische nationaliteit [...] de gewone verblijfplaats in Belgisch Congo of in de gebieden Ruanda en Urundi, tijdens het Belgisch bestuur".

314 "y est également assimilée, la résidence habituelle dans la République du Congo ou au Ruanda ou en Urundi au cours des trois années postérieures à leur accession à l'indépendance, pourvu que cette résidence ait commencé antérieurement à l'accession à l'indépendance ou qu'elle fasse suite à une résidence établie en Belgique"/ "wordt daarmee eveneens gelijkgesteld de gewone verblijfplaats in de Republiek Congo of in Ruanda of Urundi gedurende de drie jaren na de dag waarop zij onafhankelijk zijn geworden, op voorwaarde dat de verblijfplaats aldaar reeds gevestigd was vóór de onafhankelijkheid of aansluit bij een in België gevestigde verblijfplaats".

315 "Le bénéfice de la disposition qui précède est subordonné au transfer ten Belgique de la résidence habituelle précédemment fixée dans la République du Congo, au Ruanda ou en Urundi, à condition que ce transfert s'accomplisse dans le délai de trois ans prévu au paragraphe précédent." " Het voordeel van de vorenstaande bepaling is afhankelijk van de overbrenging naar België van de gewone verblijfplaats die tevoren in de Republiek Congo of in Ruanda of Urundi was gevestigd op voorwaarde dat de overbrenging geschiedt binnen de in de vorige paragraaf bepaalde termijn van drie jaren".

316 See the list of Territories to which the Declaration on the Granting of Independence to Colonial Countries and Peoples (General Assembly resolution 1514 (XV) of 14 December 1960) applies, Official Records of the General Assembly, Eighteenth Session, Annexes, addendum to agenda item 23 (A/54/46/Rev.1), annex I. Nowdays, a dozen of territories are still listed as Non self-Governing Territories under the administration of the United Kingdom, i.e., Anguilla, Bermuda, British Virgin Islands, Cayman Islands, Falkland Islands (Malvinas), Montserrat, Saint Helena, Turks and Caicos Islands, Gibraltar, and the Pitcairn Islands. 
Fransman lists up to ten different terms used in British nationality legislation which are used to describe the status of a particular "Non-SelfGoverning territory" at a particular time. ${ }^{317}$ These categories are as follows: within the Crown's dominion, Dominion, British protectorate, British Protected State, mandate/trust territory, foreign State/territory in which the Crown exercised extraterritorial jurisdiction over British subjects, within the United Kingdom and Colonies, Associated States, independent Commonwealth country, and British dependent territory/British overseas territory. Accordingly, different categories of nationality where attached to the above-mentioned categories of territory. More than twenty different categories can be counted in British nationality law in retrospect.

Until 1948 there were two main categories of British nationality: British subjects from the Crown's dominion and British protected persons from protected foreign territory. ${ }^{318}$ From 1949 to 1982, it was possible to identify, together with "residual categories of British subjects", ${ }^{19}$ four main categories of nationality, i.e. citizens of the United Kingdom and Colonies, citizens of independent Commonwealth countries, Commonwealth citizens and British protected persons from protected foreign territory. ${ }^{320}$ Further to this, between 1948 and 1980, most of these territories gained independence from the United Kingdom.

Regarding the practice of the United Kingdom upon the independence of former British colonies, associated States, protectorates, protected States and mandated/trust territories, it has been routine for specific provisions to be introduced in the British independence legislation for the general loss of British nationality on the date of independence. As pointed out by Laurie Fransman, ${ }^{321}$ it is realistic to expect that at least some remaining British overseas territories will gain independence in the future ${ }^{322}$ or become part of entities that are already independent. If customary course is followed, those who are British overseas territories citizens and/or British citizens by virtue of a connection with that British overseas territory, "will generally cease to be such citizens on the date of

317 Laurie Fransman, Fransman's British Nationality Law, Bloomsbury Professional, West Sussex, 2011 (3rd edition), p. 65.

318 Laurie Fransman, Fransman's British Nationality Law, Bloomsbury Professional, West Sussex, 2011 (3rd edition), p. 63.

319 Laurie Fransman, Fransman's British Nationality Law, Bloomsbury Professional, West Sussex, 2011 (3rd edition), p. 63.

320 Laurie Fransman, Fransman's British Nationality Law, Bloomsbury Professional, West Sussex, 2011 (3rd edition), p. 65.

321 Laurie Fransman, Fransman's British Nationality Law, Bloomsbury Professional, West Sussex, 2011 (3rd edition), p. 607.

322 Laurie Fransman mentioned the specific case of Bermuda. 
independence or cession, as the case may be if on that date they become citizens of the independent State (...)".323

The general formula used to date in respect of the nationality arrangements upon independence is that on the appointed day, if a person becomes a national of the newly independent State under its initial laws, then subject to exceptions based in a connection with the United Kingdom or a remaining British colony, that person ceases to be a British citizen on that day. Later withdrawal by the newly independent State of its nationality does not resurrect British citizenship for an individual who automatically ceased to be a British citizen under these arrangements on the date of independence. ${ }^{324}$

Hereinafter, a brief analysis of the nationality provisions which were adopted as a consequence of the independence of the former colonies of the United Kingdom will be provided. Due to the large number of former British territories which gained independence and the variety of rules regarding the nationality status of individuals involved, only a selection of those provisions will be analysed. The way in which the system worked can be well illustrated by pointing to provisions that were enacted following, inter alia, the independence of Ghana, the Malayan Federation, Zambia and Malawi.

The territory of Ghana was composed by an amalgamation of territorial entities (Gold Coast Colony, Ashanti, the Northern Territories Protectorate and British Togoland) that were collectively administered by the United Kingdom. These territories achieved independence as Ghana on 6 March 1957. ${ }^{325}$ According to the Ghana Independence Act of 1957, ${ }^{326}$ British protected persons ceased to hold that status when they acquired the nationality of the new independent State of Ghana. Section 2 thereof explained that:

323 Laurie Fransman, Fransman's British Nationality Law, Bloomsbury Professional, West Sussex, 2011 (3rd edition), p. 607.

324 Laurie Fransman, Fransman's British Nationality Law, Bloomsbury Professional, West Sussex, 2011 (3rd edition), p. 607.

325 For further information on the history of Ghana as a former British administered territory see Laurie Fransman, Fransman's British Nationality Law, Bloomsbury Professional, West Sussex, 2011 (3rd edition), pp. 937-952.

326 Act to make provision for, and in connection with, the attainment by the Gold Coast of fully responsible status within the British Commonwealth of Nations, 7 February 1957, available at http://www.legislation.gov.uk/ukpga/1957/6/pdfs/ ukpga 19570006 en.pdf. 
“(...) Provided that a person who, immediately before the appointed day, was for the purposes of the said Act and Order in Council a British protected person by virtue of his connection with either of the territories mentioned in paragraph (b) of this section shall not cease to be such a British protected person for any of those purposes by reason of anything contained in the foregoing provisions of this Act, but shall so cease upon his becoming a citizen of Ghana under any law of the Parliament of Ghana making provision for such citizenship".

Similarly, the Malaysia Act of $1963^{327}$ provided for a general loss of the status of citizen of the United Kingdom and Colonies for those who acquired, on or after independence, Malaysian nationality. The provision in the Malaysia Act was more straightforward in comparison to its corresponding provision in the Ghana Independence Act 1957. Section 2 of the Malaysia Act 1963 read as follows:

“(...) (2) Save as provided by Schedule 1 to this Act, any person who immediately before the appointed day is a citizen of the United Kingdom and Colonies shall on that day cease to be such a citizen if on that day he becomes a citizen of the Federation".

It is remarkable that, unlike the Ghana Independence Act 1957, the Malaysia Act 1963 also provided a set of exceptions to the general rule of loss of the status of citizen of the United Kingdom and Colonies when acquiring Malaysian nationality. Schedule 1 of the Malaysia Act laid down a set of exceptions based on the existence of a connection with the United Kingdom or a remaining British colony:

"1. Subject to paragraph 5 of this Schedule, a person shall not cease to be a citizen of the United Kingdom and Colonies under section 2(2) of this Act if he, his father or his father's father- (a) was born in the United Kingdom or in a colony; or (b) is or was a person naturalised in the United Kingdom and Colonies; or (c) was registered as a citizen of the United Kingdom and Colonies; or(d) became a British subject by reason of the annexation of any territory included in a colony.

2. A person shall not cease to be a citizen of the United Kingdom and Colonies under section 2(2) of this Act if he was born in a protectorate or protected state, or if his father or his father's father was so born and is or at any time was a British subject.

327 Act to make provision for and in connection with the federation of North Borneo, Sarawak and Singapore with the existing States of the Federation of Malaya, 31 July 1963, available at http://www.legislation.gov.uk/ukpga/1963/35/pdfs/ ukpga 19630035 en.pdf. 
3. A woman who is the wife of a citizen of the United Kingdom and Colonies shall not cease to be such a citizen under section 2(2) of this Act unless her husband does so.

\section{$(\ldots) "$}

After a period in which the territory of Zambia previously belonged to the British South Africa Company (according to the Royal Charter of Cecil Rhodes' British South Africa Company) ${ }^{328}$ it achieved the status of British Protectorate in 1949. ${ }^{329}$ In 1953, it became part of the Federation of Rhodesia and Nyasaland (still as a British protectorate) and, although it achieved independence in 1958 as part of that Federation, once the Federation was dissolved in January 1964, it "recovered" the status of British protectorate. In October 1964 Zambia became an independent State. Following the trend established in the Ghanaian and Malaysian independence acts, the Zambia Independence Act of $1964^{330}$ included a provision on loss of British protected person/citizen of the United Kingdom and Colonies status (Section 3) and another on the retention citizenship of United Kingdom and Colonies (Section 4) as follows:

Section 3: "(2) A person who, immediately before the appointed day, is for the purposes of those Acts and of the said Order in Council of 1949 a British protected person by virtue of his connection with Northern Rhodesia shall not cease to be such a British protected person for any of those purposes by reason of anything contained in the preceding provisions of this Act, but shall so cease upon his becoming a citizen of Zambia.

(3)Except as provided by section 4 of this Act, any person who immediately before the appointed day is a citizen of the United Kingdom and Colonies shall on that day cease to be such a citizen if he becomes on that day a citizen of Zambia.

$(\ldots)$

328 Martin Chanock, Unconsummated Union: Britain, Rhodesia and South Africa, 190045, Machester University Press, Manchester, 1977, p. 12.

329 For further information on the history of Zambia as a former British administered territory see Laurie Fransman, Fransman's British Nationality Law, Bloomsbury Professional, West Sussex, 2011 (3rd edition), pp. 1379-1389.

330 Act to make provision for, and in connection with, the establishment of Northern Rhodesia, under the name of Zambia, as an independent republic within the Commonwealth, 31 July 1964, available at http://www.legislation.gov.uk/ ukpga/1964/65/pdfs/ukpga_19640065 en.pdf. 
Section 4: "(1)Subject to subsection (5) of this section, a person shall not cease to be a citizen of the United Kingdom and Colonies under section 3(3) of this Act if he, his father or his father's father-(a) was born in the United Kingdom or in a colony; or (b) is or was a person naturalised in the United Kingdom and Colonies; or (c) was registered as a citizen of the United Kingdom and Colonies; or (d) became a British subject by reason of the annexation of any territory included in a colony.

(2)A person shall not cease to be a citizen of the United Kingdom and Colonies under the said section 3(3) if either-(a) he was born in a protectorate or protected state, or (b) his father or his father's father was so born and is or at any time was a British subject.

\section{$(\ldots)$.}

Malawi, like Zambia, was also part of the Federation of Rhodesia and Nyasaland. ${ }^{331}$ Following the dissolution of the Federation, it recovered the status of British protectorate, and ultimately achieved independence in July 1964. The Malawi Independence Act $1964^{332}$ also included provisions regarding loss of the status of British protected person/citizen of the United Kingdom and Colonies and retention of the citizenship of the United Kingdom and Colonies. The provisions in Malawian act are identical to the ones on the Zambia Independence Act, only the numbering of the sections and the references to the countries change. ${ }^{333}$

331 For further information on the history of Zambia as a former British administered territory see Laurie Fransman, Fransman's British Nationality Law, Bloomsbury Professional, West Sussex, 2011 (3rd edition), pp. 1067-1079.

332 Act to make provision for and in connection with the attainment by Nyasaland of fully responsible status within the Commonwealth, 10 June 1964, available at http://www.legislation.gov.uk/ukpga/1964/46/pdfs/ukpga 19640046 en.pdf.

333 The text of these provisions reads as follows:

Section 2: "(2) A person who, immediately before the appointed day, is for the purposes of the said Acts and Order in Council a British protected person by virtue of his connection with the Nyasaland protectorate shall not cease to be such a British protected person for any of those purposes by reason of anything contained in the preceding provisions of this Act, but shall so cease upon his becoming a citizen of Malawi.

(3) Except as provided by section 3 of this Act, any person who immediately before the appointed day is a citizen of the United Kingdom and Colonies shall on that day cease to be such a citizen if he becomes on that day a citizen of Malawi.

(...)".

Section 3: "(1) Subject to subsection (5) of this section, a person shall not cease to be a citizen of the United Kingdom and Colonies under section 2(3) of this Act if he, his father or his father's father- (a) was born in the United Kingdom or in a colony; or (b) is or was a person naturalised in the United Kingdom and Colonies; or (c) was registered as a citizen of the United Kingdom and Colonies; or (d) became a 
Generally speaking, in all former British colonies territories that achieved independence, the provisions dealing with the consequences for the British nationality had a recurring theme: the person who becomes national of the newly independent State under its initial laws, he or she ceases on that day to be a British citizen subject to exceptions based on a connection with the United Kingdom or remaining British colonies. Similar provisions can be found in the independence acts of the following former British colonies: Uganda, ${ }^{334}$ Kenya, ${ }^{335}$ Gambia, ${ }^{336}$ Botswana, ${ }^{337}$ Lesotho, ${ }^{338}$ Malta, ${ }^{339}$ Trinidad

British subject by reason of the annexation of any territory included in a colony.

(2) A person shall not cease to be a citizen of the United Kingdom and Colonies under the said section 2(3) if either- (a) he was born in a protectorate or protected state, or (b) his father or his father's father was so born and is or at any time was a British subject.

(...)".

334 Act to make provision for, and in connection with, the attainment by Uganda of fully responsible status within the Commonwealth, 1 August 1962, Section 2, available at http://www.legislation.gov.uk/ukpga/1962/57/pdfs/ukpga 19620057 en.pdf..

335 Act to make provision for, and in connection with, the attainment by Kenya of fully responsible status within the Commonwealth, including provision for terminating the giving of financial and other assistance to the East African Common Services Organisation under the Colonial Development and Welfare Act 1959, 3 December 1963, Sections 2 and 3, available at http://www.legislation.gov.uk/ ukpga/1963/54/pdfs/ukpga 19630054 en.pdf.

336 Act to make provision for, and in connection with, the attainment by The Gambia of fully responsible status within the Commonwealth, 17 December 1964, Sections 2 and 3, available at http://www.legislation.gov.uk/ukpga/1964/93/pdfs/ukpga 19640093 en.pdf.

337 Act to make provision for, and in connection with, the establishment of the Bechuanaland Protectorate, under the name of Botswana, as an independent republic within the Commonwealth, 3 August 1966, Sections 3 and 4, available at http://www.legislation.gov.uk/ukpga/1966/23/pdfs/ukpga_19660023 en.pdf.

338 Act to make provision for, and in connection with, the establishment of Basutoland, under the name of Lesotho, as an independent kingdom within the Commonwealth, 3 August 1966, Sections 3 and 4, available at http://www.legislation.gov.uk/ ukpga/1966/24/pdfs/ukpga 19660024 en.pdf.

339 Act to make provision for, and in connection with, the attainment by Malta of fully responsible status within the Commonwealth, 31 July 1964, Sections 2 and 3, available at http://www.legislation.gov.uk/ukpga/1964/86/pdfs/ukpga_19640086_en.pdf. 
and Tobago, ${ }^{340}$ Barbados, ${ }^{341}$ Guyana, ${ }^{342}$ Jamaica ${ }^{343}$ and Cyprus. ${ }^{344}$

In answering the question of who kept British nationality it largely depended on the fact that one would acquire the nationality of the newly independent State. Thus, it was essential to be aware of the nationality legislation enacted by the newly independent State upon its independence. An example is given by the legislation passed by Nigeria upon its independence on 1 October $1960 .{ }^{345}$ According to Chapter II of the Nigerian Constitution of 1960, Chapter II on citizenship, section 7 stipulated that:

"(1) Every person who, having been born in the former Colony or Protectorate of Nigeria, was on the thirtieth day of September, 1960, a citizen of the United Kingdom and Colonies or a British protected person shall become a citizen of Nigeria on the first day of October, 1960:

Provided that a person shall not become a citizen of Nigeria by virtue of this subsection if neither of his parents nor any of his grandparents was born in the former Colony or Protectorate of Nigeria.

(2) Every person who, having been born outside the former Colony and Protectorate of Nigeria, was on the thirtieth day of September, 1960, a citizen of the United Kingdom and Colonies or a British

340 Act to make provision for, and in connection with, the attainment by Trinidad and Tobago of fully responsible status within the Commonwealth, 1 August 1962, Sections 2 and 3, available at http://www.legislation.gov.uk/ukpga/1964/86/ pdfs/ukpga 19640086 en.pdf.

341 Act to make provision for, and in connection with, the attainment by Barbados of fully responsible status within the Commonwealth, 17 November 1966, Sections 2 and 3, available at http://www.legislation.gov.uk/ukpga/1966/37/pdfs/ ukpga 19660037 en.pdf.

342 Act to provide for the attainment by British Guiana of fully responsible status within the Commonwealth; to make provision as to the effect of certain certificates of naturalisation; and for purposes connected with the matters aforesaid, 12 May 1966, Sections 2 and 3, available at http://www.legislation.gov.uk/ukpga/1966/14/ pdfs/ukpga 19660014 en.pdf.

343 Act to make provision for, and in connection with, the attainment by Jamaica of fully responsible status within the Commonwealth, 19 July 1962, Section 2, available at http://www.legislation.gov.uk/ukpga/1962/40/pdfs/ukpga_19620040_en.pdf.

344 Act to make provision for, and in connection with, the establishment of an independent republic in Cyprus, 29 July 1960, Section 4, available at http://www. legislation.gov.uk/ukpga/1960/52/pdfs/ukpga 19600052 en.pdf.

345 For further information on the history of Nigeria as a former British administered territory see Laurie Fransman, Fransman's British Nationality Law, Bloomsbury Professional, West Sussex, 2011 (3rd edition), pp. 1147-1164. 
protected person shall, if his father was born in the former Colony or Protectorate and was a citizen of the United Kingdom and Colonies or a British protected person on the thirtieth day of September, 1960, (or, if he died before that date, was such a citizen or person at the date of his death or would have become such a citizen or person but for his death) become a citizen of Nigeria on the first day of October, 1960".

Also remarkable is the reference made in section 13 of the Constitution to the status of Commonwealth citizens:

"(1) Every person who under this Constitution or any Act of Parliament is a citizen of Nigeria or under any enactment for the time being in force in any country to which this section applies is a citizen of that country shall, by virtue of that citizenship, have the status of a Commonwealth citizen.

(2) Every person who is a British subject without citizenship under the British Nationality Act, 1948, or who continues to be a British subject under section 2 of that Act shall by virtue of that status have the status of a Commonwealth citizen.

\section{$(\ldots) "$}

The status of Commonwealth citizen is a common status of all kind of British nationality status and citizens of any Commonwealth country as listed in the British Nationality Act. However, it will come as no surprise that the legislation of a Commonwealth independent country like Nigeria makes such a reference since, according to Laurie Fransman, ${ }^{346}$ the acquisition and loss of this status is a matter to be regulated by the Commonwealth independent country itself.

However, as seen above, the United Kingdom did not put the continuation of the British citizenship completely in the hands of the newly independent State. If a person had obvious ties with the United Kingdom, he or she had the possibility to retain British citizenship. For example, in the Nigeria Independence Act $1960,{ }^{347}$ similar provisions to the ones in Ghana, Malayan Federation, Zambia or Malawi could be found. Thus section 2 read as follows:

346 Laurie Fransman, Fransman's British Nationality Law, Bloomsbury Professional, West Sussex, 2011 (3rd edition), p. 655.

347 An Act to make provision for, and in connection with, the attainment by Nigeria of fully responsible status within the Commonwealth, 29 July 1960, available at http://www.legislation.gov.uk/ukpga/1960/55/pdfs/ukpga_19600055 en.pdf. 
“(...)

Provided that a person who immediately before the appointed day is for the purposes of the said Acts and Order in Council a British protected person by virtue of his connection with the Nigeria Protectorate shall not cease to be such a British protected person for any of those purposes by reason of anything contained in the foregoing provisions of this Act, but shall so cease upon his becoming a citizen of Nigeria under the law thereof.

(2) Subject to the subsequent provisions of this section, any person who immediately before the appointed day is a citizen of the United Kingdom and Colonies shall on that day cease to be such a citizen if - (a) under the law of Nigeria he becomes on that day a citizen of Nigeria; and (b) he, his father or his father's father was born in any of the territories comprised in Nigeria.

(3) Subject to subsection (8) of this section, a person shall not cease to be a citizen of the United Kingdom and Colonies under the last foregoing subsection if he, his father or his father's father- (a) was born in the United Kingdom or in a colony; or (b) is or was a person naturalised in the United Kingdom and Colonies; or (c) was registered as a citizen of the United Kingdom and Colonies; $o$ (d)became a British subject by reason of the annexation of any territory included in a colony.

(4)A person shall not cease to be a citizen of the United Kingdom and Colonies under subsection (2) of this section if he was born in a protectorate, protected state or United Kingdom trust territory, or if his father or his father's father was so born and is or at any time was a British subject.

Regarding the approach to dual nationality, upon independence and due to the operation of the provisions on loss of British citizenship when acquiring the nationality of the newly independent State, dual nationality was in principle not accepted. The United Kingdom, ever since the commencement of the British Nationality Act 1948, has been accepting of multiple nationalities. ${ }^{348}$ Since 1 January 1949 , the voluntary acquisition

348 The voluntary acquisition of a foreign nationality was a ground for loss under the British Nationality and Status of Aliens Act 1914, section 13. See on that provision J. Mervyn Jones, British Nationality Law and Practice, Clarendon Press, Oxford, 1947, pp. $195 \mathrm{ff}$. 
of a foreign nationality did not automatically cause the loss of the British nationality. Nevertheless, in the context of State succession of former territories administered by the United Kingdom, dual nationality was not systematically promoted. Continuing with the Nigerian example, section 12 of the 1960 Constitution, under the heading "dual citizenship", did not allow such for a system:

"Any person who, upon his attainment of the age of twenty-one years, was a citizen of Nigeria and also a citizen of some country other than Nigeria shall cease to be a citizen of Nigeria upon his attainment of the age of twenty-two years (or, in the case of a person of unsound mind, at such later date as may be prescribed by Parliament) unless he has renounced his citizenship of that other country, taken the oath of allegiance and, in the case of a person who is a citizen of Nigeria by virtue of subsection (2) of section 7 of this Constitution, has made such declaration of his intentions concerning residence or employment as may be prescribed by Parliament:

Provided that where a person cannot renounce his citizenship of the other country under the law of that country he may instead make such declaration concerning that citizenship as may be, prescribed by Parliament".

\subsection{Identified Patterns}

Having looked at the attitudes and reactions of Spain, Belgium and the United Kingdom towards the independence of their colonies and protectorates during the decolonisation process after WWII, the following remarks can be made.

Regarding Spain, one cannot understand the Spanish reaction towards the independence of its colonies without first understanding the concept of súbdito español. Although Ifni, Equatorial Guinea and Western Sahara were integrated into the Kingdom of Spain as Spanish provinces, it was the case that the territorial assimilation was not reflected in the nationality status of the inhabitants of those territories. Those súbditos españoles were not considered Spanish nationals but rather Spanish subjects who benefited from Spanish nationality. Upon independence, these inhabitants were offered the option to acquire the Spanish nationality. ${ }^{349}$

349 Notice that this option was only offered to súbditos españoles in Ifni and Western Sahara. In the case of Equatorial Guinea, no specific provision regarding the right to opt for Spanish nationality was passed and, more generally, the Spanish authorities passed no provision dealing with nationality in the context of the independence of Equatorial Guinea. 
However, that option, in practice, was quite difficult, if not impossible, to exercise.

An interesting feature that can be observed nowadays in the Spanish legislation on nationality is the privileged position of nationals of former Spanish colonies regarding the acquisition of Spanish nationality. Under the umbrella of hispanidad, the Spanish legislature has not only foreseen an easy path to acquire Spanish nationals by nationals of former colonies but it also has permitted dual nationality if the Spanish nationality is combined with the nationality of one the Latin American countries, the Philippines, Equatorial Guinea or Portugal. This construction has certain relevance if Catalonia were to become independent, since it would be difficult to argue that there is no room for Catalonia under the umbrella of hispanidad. ${ }^{350}$

For Belgium, it is remarkable how the independence of Congo triggered a unilateral reaction of the Belgian legislator causing it to amend the nationality act. Nowadays, this kind of unilateral legislative reaction would hardly be advisable, especially since EU Member States are obliged to take into account the principle of proportionality when drafting their nationality legislation. ${ }^{351}$

Also remarkable is the attitude towards dual nationality, which was clearly not accepted by the Belgian Government. The amendment of the Belgian nationality legislation took for granted that the acquisition of the Congolese nationality implied the loss of the Belgian nationality. All three States take as a starting point that the acquisition of the nationality of the newly independent State caused the loss of the former status. The United Kingdom made some exceptions to this general rule and, in the case of Belgium, the possibility to recover the Belgian nationality was also provided. However, in the later case, recovering the Belgian nationality implied losing Congolese nationality.

The United Kingdom not only possesses a wealth of experience in dealing with the independence of its non-European colonies, but a remarkably consistent practice has emerged in the independence acts. Thus, as a general rule, people who became nationals of the newly independent State ceased to be a British citizen. However, certain exceptions were provided for which were generally based on a connection to the United Kingdom or the remaining British colonies.

\footnotetext{
350 Although the Western Sahara constitutes a precedent. See section 6.1.3.

351 See Chapter 4, section 3.
} 
Not surprisingly, dual nationality schemes were not mentioned in the nationality legislation enacted within the framework of the decolonisation process in the countries at stake. Spain, Belgium and the United Kingdom currently accept dual nationality in their nationality legislation. However, that has not always been the case. Historically, holding the nationality of more than one country was considered an anomaly that, even international treaties, tended to fight and avoid where possible. Thus, it could not be expected that dual nationality schemes were accepted or offered in the context of the decolonisation process. Furthermore the fact that the principle of equal treatment of women and children in nationality issues was not yet enshrined did little to help consolidate such an attitude towards dual nationality. ${ }^{352}$

\section{Concluding Remarks}

The question of Statehood or achieving the status of a State in the international community is of upmost importance. Despite the complexity involved in the creation of States, due to the interaction of legal and factual dimensions, achieving that status is still appealing, given the primary role that States play in the international community. Thus, it will come as no surprise that in recent years devolved regions within a State, like Catalonia, Flanders and Scotland, have intensified their efforts to achieve Statehood. One of the arguments put forward by independence advocates in these regions is the so-called right to self-determination. This right has to be put in context, not only with the principle of territorial integrity, but it must also be remembered that with regard to Catalonia, Flanders and Scotland, we are not dealing with a case of decolonisation. Within the borders of their respective countries and outside the colonial context, it is hard to argue for the existence of a right to external self-determination, even under the theory of remedial secession. Catalonia, Flanders, and Scotland are not colonies possessing a right to external self-determination nor are they victims of repression such that an eventual right to remedial secession may apply. The only claim of self-determination that would be most likely to succeed in Catalonia, Flanders and Scotland is the right to internal self-determination. In this sense, it is possible to argue that these regions are not only entitled to internal self-determination, but that they already enjoy such a right. The devolution process which has been witnessed in these regions has an obvious impact on the protection of the Catalan, Flemish, and Scottish peoples' culture and identity. In the light of this right to self-determination, the analysis made by the Supreme Court

352 As a general rule, and under the rule of famility unity, women were required to adopt the nationality of the husband upon marriage and, therefore, the children followed the "family unit". 
of Canada has significant implications for the three regions at stake. Of particular importance are the remarks made by the Canadian Supreme Court on the obligation to negotiate, especially when there is a clear majority in favour external self-determination/secession. In this sense, a stark comparison can be made between the situation in Scotland and in Catalonia. In the case of Scotland, it was particularly salient that there was a willingness on behalf of the British Government to negotiate the terms of a referendum on Scottish independence. In the case of Catalonia, however, it cannot be said that there was the same political will as was witnessed in Scotland, since there was no such negotiation between the Spanish Government and Catalonia. Indeed, the Spanish Government ruled out the possibility of initiating any constitutional amendments in response to the independence claims of the Catalan people.

As regards the question of membership of international organisations, two opposing positions have been analysed in this chapter. On the side of the regions where independence is being discussed, the argument of automatic accession to international organisations upon independence has been put forward. However, this presumption of automatic membership to the EU of the newly independent States seems to conflict with the official position of the European Commission, as expressed by former Presidents Romano Prodi and José Manuel Barroso, and the current President, Jean-Claude Juncker. The default response in relation to the independence of part of an EU Member State has been the so-called 'Barroso doctrine', which espouses that a new independent State would become a third country with respect to the EU, the treaties would no longer apply on its territory from the day of its independence and it would have to apply for membership following the procedure so established in the treaties. Both international law and the practice of international organisations support the Barroso doctrine. In this sense, the theories supporting the automatic accession (accession from within/internal enlargement) of these regions are, as pointed out by De Waele, highly speculative. ${ }^{353}$

International organisations usually require new States to accede in order to acquire membership. Although secession from an EU Member State would be unprecedented and the EU's governing treaties offer no guidance as to how such a situation should be handled, there are certain reasons why the general requirement of accession may apply. There is no legal basis in the EU treaties or the Vienna Convention on Succession of States in Respect of

353 Henri de Waele, "Afscheiding van delen van EU-lidstaten -de Europeesrechtelijke implicaties", SEW, 2016, p. 6. See also Araceli Mangas Martín, "La Secesión de Territorios en un Estado Miembro: efectos en el Derecho de la Unión Europea", Revista de Derecho de la Unión Europea No. 25, July-December 2013, pp. 60-61. 
Treaties that endorse the automatic membership of the newly independent State upon independence. Spain, Belgium and the United Kingdom would retain their EU membership despite a loss of their geographical territory, while the potential new States would have to apply for membership as new independent States. In fact, the only likely scenario in which such an automatic accession would be applicable would be if the new independent State retains the international legal personality of the predecessor EU Member State. According to the Scharf criteria, that could potentially be the case for Flanders, but not for Catalonia or Scotland. However, it is worth noting that there has been a rather inconsistent application of the theory of the continuing State to membership of international organisations. In any case, the conclusion regarding the question of membership to international organisations seems rather clear from a legal perspective: the newly independent States must first acquire Statehood before acceding to the EU. Therefore, an interim period between independence and accession to the EU will, in principle, exist. Consequently, the newly independent State is not a Member State of the EU and EU law is not applicable on the territory of that new State. ${ }^{354}$ However, the fact that the new State is not a Member State of the EU, does not imply that EU law is not relevant for the nationality law issues arising as consequence of the independence process.

Automatic accession to international human rights treaties requires special attention. Although it is not yet an accepted rule of customary international law, this theory has been embraced by both the ICJ and the ECtHR. The relevance of the automatic accession of a potential Catalan, Flemish or Scottish independent State to human rights treaties and, more specifically, to the ECHR will be assessed more fully in Chapter 5 .

As regards the international rules regarding the acquisition and loss of nationality in a State succession scenario, the following conclusions can be drawn. First, it has to be stressed that, despite the efforts of the ILC, the complexity of the topic and the reluctance or lack of interest of States to regulate this question have made the task of codifying the law of State succession and, more specifically, the consequences of State succession for nationality of natural persons a rather difficult one. The Draft Articles on Nationality of Natural Persons in Relation to the Succession of States has not been put on a legally binding footing, and the issue of nationality and State succession has completely disappeared from the UN General Assembly's agenda. This therefore means that the Draft Articles can only serve as mere guidance to nationality issues in a State succession scenario.

Several conclusions, however, can be drawn from the analysis of the

354 See Chapter 2, sections 3 and 7. 
Draft Articles. As a starting point, the exchange of information and consultations between States concerned are essential to identify the negative repercussions that a State succession may have both on the nationality of the persons concerned and on other issues intrinsically linked to nationality. This "duty" of reaching negotiated solutions is a consistent feature in all the international instruments dealing with State succession, which has been especially emphasised when dealing with nationality. Point 4 of the Venice Declaration remarks that States involved may, by agreement, settle the question of nationality; equally, Article 19 of the ECN requires States concerned to regulate nationality matters by agreement amongst themselves and the Convention on the Avoidance of Statelessness in relation to State Succession contains a similar provision in Article 13. The "duty" to negotiate is also reinforced at EU level on the side of the predecessor EU Member State which must observe the principle of proportionality when drafting the new nationality legislation in the event of the independence of part of its territory ${ }^{355}$ and this issue was also mentioned in the decision of the Supreme Court of Canada Reference re Secession of Quebec.

The Draft Articles provide a set of factors to be taken into account when attributing the nationality of the new State upon independence, including the default criterion "any other appropriate connection". The habitual residence in the territory of the new State (while holding the nationality of the predecessor State) seems to be the preferred criterion to take into account when grating the nationality of the newly independent State, not only according to the Draft Articles, but also according to the Venice Declaration (point 8.a), the ECN (Article 18(2)(b)) and the Convention on the Avoidance of Statelessness in relation to State Succession (Article $5(1)(a))$. On the basis of the habitual residence criterion, Article 25 of the Draft Articles seems to oblige the predecessor State to withdraw its nationality from some categories of person acquiring the nationality of the successor State -amongst them, those having their habitual residence in the territory of the successor State. Although the content of this obligation must be considered against the backdrop of a possible option right, if the predecessor State follows the mandate of Article 25, that would amount leaving the decision to withdraw the EU citizenship status in the hands of the successor non-EU Member State. In this context, it seems preferable to follow point 12 of the Venice Declaration which imposes a negative obligation on the predecessor State: "the predecessor State shall not withdraw its nationality from its own nationals who have been unable to acquire the nationality of a successor State". It is also remarkable that the $2006 \mathrm{ECN}$ is silent on this point.

355 See Chapter 5, section 3. 
In any case, it also seems to be a recurring feature that nationals of the predecessor State who are habitually resident in the territory of the new State should acquire the nationality of the new State. In other words, the predecessor State can (even shall) withdraw its nationality to those nationals that acquire the nationality of the new successor State. Although this practice is not problematic from an international law perspective, it may be problematic from EU law perspective. ${ }^{356}$

Other criteria relevant to granting/offering the nationality of the successor State include birth on the territory of the new State (Articles 22(b)(ii) and 24(b)(ii) of the ILC Draft Articles, point 9(a) of the Venice Declaration, Article 18(2)(d) of the ECN, and Article 5(1)(b) in conjunction with Article 5(2)(b) of the Convention on the Avoidance of Statelessness in relation to State Succession) or last habitual residence on the territory of the successor State prior to the State succession (Articles 22(b)(ii) and 24(b) (ii) of the ILC Draft Articles, Article 5(1)(b) in conjunction with Article (5)(2)(c) of the Convention on the Avoidance of Statelessness in relation to State Succession). As a concluding remark, it is possible, in light of the aforementioned provisions, that nationals of the predecessor State residing in the successor State (or even third States) should be offered the possibility to acquire the nationality of the new State, if an appropriate connection with the latter State exists.

It is also worth mentioning that there is a category of people that receive almost no consideration in international instruments dealing with nationality and State succession, notwithstanding the fact that they are also affected by State succession. Nationals of countries not involved in the State succession but residing in the territory of the successor State receive little attention. The ILC Draft Articles exclude, from the onset, nationals of other States from its scope of application, since the definition provided for "person concerned" in Article 2(f) "includes neither persons who are only nationals of third States nor stateless persons who were present on the territory of any of the States concerned" ${ }^{357}$ Neither the ECN, nor the Convention on Avoidance of Statelessness in relation to State Succession addresses the situation of nationals of third countries residing on the territory of the successor State. The Venice Declaration, however, provides that where nationals of a third State are permanently resident on that

356 See Chapter 4, section 3.

357 See commentary to Article 1 of the Draft Articles on Succession of States in respect of Treaties with commentaries, Report of the Commission to the General Assembly, Yearbook of the International Law Commisssion, 1974, Vol. II, Part One. The defition of "person concerned" reads as follows: "Person concerned means every individual who, on the date of the succession of States, had the nationality of the predecessor State and whose nationality may be affected by such succession". 
territory, then it may be possible for them to acquire the nationality of the successor State. ${ }^{358}$ With the only exception found in the Venice Declaration, it seems that international law has not been considered important enough to regulate the status of third country nationals habitually residing on the territory of the successor State. Perhaps providing a right to opt for the nationality of the new independent State could be seen as going too far, but at least it seems desirable to preserve their status as a permanent resident. This question will be given fuller consideration in the following chapter, when assessing the participation of third country nationals in the independence referendum and their (almost non-existent) chances of acquiring the nationality of the new independent State.

Another question that the international instruments tackle is the right of option. Attention has to be paid to the wishes of the person involved, in particular by providing option rights (Article 11 ILC Draft Articles, point 13 to 16 of the Venice Declaration, Article 18(2)(c) of the ECN, and Article 7 of the Convention on the Avoidance of Statelessness in relation to State Succession). It is remarkable the wording of Article 16 of the Venice Declaration: "The exercise of the right to choose the nationality of the predecessor State, or of one of the successor States, shall have no prejudicial consequences for those making that choice, in particular with regard to their right to residence in the successor State (...)". This question is addressed further in Chapter 5 and in connection to the exercise of an eventual autonomous right of option for minors.

Another consistent feature of the international instruments studied in section 5 is the avoidance of statelessness as a result of a State succession. The Draft Articles stipulate a general presumption of change of nationality for those nationals of the predecessor State having their habitual residence in the territory of the successor State. The issue of preventing statelessness is also tackled in the 1961 Convention on Reduction of Statelessness but only addressing the specific case of transfer of a territory. ${ }^{359}$ Similarly, the Venice Declaration takes as a starting point that States involved in the State succession shall avoid creating cases of statelessness and, in the same vein, Article 18(1) of the ECN stresses the avoidance of statelessness in State succession scenarios. And, obviously, the Convention on the Avoidance

358 Point 9.b of Declaration on the Consequences of State Succession for the Nationality of Natural Persons, adopted by the European Commission for Democracy through Law at its 28th Plenary Meeting (Venice, September 1996): "It is desirable that successor States grant their nationality, on an individual basis, to applicants belonging to the following two categories (...) b. permanent residents of the transferred territory who, at the time of succession, hold the nationality of a third State".

359 Of the three EU Member States under analysis only Belgium (1 July 2014) and the United Kingdom (29 March 1966) have acceded to this Convention. 
of Statelessness in relation to State Succession is fully focused on the avoidance of statelessness. The message is very clear: statelessness as a result of a State succession must be avoided.

Finally, this chapter also studied whether lessons can be learned from the experiences of the States involved in the period of decolonisation of the nonEuropean territories. Generally, one can witness the existence of certain patterns: the acquisition of the nationality of the newly independent State caused the loss of the former status. Upon the independence of Ifni and Western Sahara, Spain offered a right of option for Spanish nationality; the United Kingdom made some exceptions to this general rule based on a connection to the United Kingdom or the remaining British colonies and, in the case of Belgium, the possibility to recover Belgian nationality was also provided for in the domestic Belgian legislation. Dual nationality schemes were not mentioned in the nationality legislation enacted within the framework of the decolonisation process in the countries under analysis and the fact that the principle of equal treatment of women and children in nationality issues was not yet enshrined did not help to consolidate such an attitude towards dual nationality.

Thus, one cannot discern patterns from the decolonisation period that would be advisable to follow in the event of a State succession. In fact, most of the practices from that period are used as guidelines. However, for the case of Spain it is the case that due to their colonial past, the nationals of former Spanish colonies have a privileged position under the current Spanish nationality legislation which is inspired by the concept of the hispanidad. As a result of this, domestic Spanish legislation enables nationals of former Spanish colonies to easily acquire Spanish nationality and dual nationality is permitted, insofar as the Spanish nationality is combined with the nationality of certain Latin American countries, the Philippines, Equatorial Guinea or Portugal. 


\section{Chapter 3: State Succession in the EU: Catalonia, Flanders and Scotland}

\section{Introduction}

Catalonia, Flanders and Scotland represent examples of regions, within EU Member States, where independence from Spain, Belgium and the United Kingdom respectively is being discussed. As has been explained in previous chapters, while in the past, parts of the territories of EU Member States have become independent, what differentiates Catalonia, Flanders and Scotland, however, is the fact that these potentially new States do not seek to withdraw from the European Union. The Catalan, Flemish, and Scottish independence movements thus pose an unprecedented challenge to the Member States they form part of and to the EU. Although none of the regions currently under scrutiny have achieved their independence, the success of nationalist parties in these territories coupled with certain political developments such as the independence referendum in Scotland and the Catalan participatory process serve as reminders that the independence of a devolved part of an EU Member State is a very real possibility. Furthermore, in the case of Scotland, the independence question has regained momentum after the referendum on United Kingdom membership of the EU.

\section{Catalonia}

The history of Catalonia with regard to becoming a part of Spain was more turbulent than peaceful. In 1137, the Count of Barcelona, Ramón Berenguer IV, married the Princess of Aragon, Petronila I, and consequently Catalonia became part of the Crown of Aragon or the Regno, Dominio et Corona Aragonum et Catalonie. ${ }^{360}$ In 1469, another dynastic union was formed, in this instance between Isabella of Castile and Ferdinand of Aragon, which led to the unification of their two realms, shaping what would later become the Kingdom of Spain. Neither the merging of the Kingdom of Aragon and the County of Barcelona, nor the integration of the Crowns of Castile

360 For further explanation on the origin of the Crown of Aragon see: Jaume Sobrequés i Callicó, Estudis d'Historia de Catalunya, Edat Mitjana, Edat Moderna, El Pactisme, Editorial Base, Vol. I, Barcelona, December 2008, pp. 53-66. For a general study of the history of Catalonia, see Albert Barcells González (ed), Arturo Pérez, Flocel Sabaté and Antoni Simon, Història de Catalunya, L'esfera dels llibres, Barcelona, January 2005. 
and Aragon put an end to the distinct institutional and parliamentary frameworks of the different constituent territorial entities. ${ }^{361}$ Despite the existence of a certain degree of harmonisation, each territory, especially those integrated into the Crown of Aragon, continued to be governed autonomously, but with a personal union at the top, i.e., their monarch.

In 1716, after the War of the Spanish Succession, during which Catalonia supported the Archduke Charles III of Austria (since 1711, Emperor Charles VI), King Philip V abolished the institutions, privileges, and the fueros ${ }^{362}$ of almost all the areas that had formerly been part of the Crown of Aragon. During the nineteenth century and the first third of the twentieth century, Catalonia experienced a cultural, social, political, and economical renaissance (Renaixença), and it recovered some of its self-governing powers. ${ }^{363}$ This Catalan renaissance period ended under Franco's dictatorship: the dictator abolished the Statute of Autonomy, the Generalitat and forbade the use of the Catalan language.

The 1978 Spanish Constitution, ${ }^{364}$ which established the current model of Autonomous Communities, "recognises and guarantees the right to autonomy of the nationalities and regions of which it is composed". ${ }^{365}$

361 The Hispanic monarchs had to swear to respect the rules, constitutions and institutions of Castile and those of the several territories forming the Crown of Aragon. E.g., the Castile Parliament proclaimed Philip V king in May 1701. On 17 September, Philip V swore to respect the Aragon fueros and on 4 October he did the same in relation to the Catalan Constitutions.

362 Fueros are municipal franchises conferred on a community by the crown, nobleman or bishop. They confirmed, inter alia, local customs or granted privileges, and exceptionally rights to taxation or self-government. Because of the great number and variety of the medieval fueros municipales and the tenacity with which the municipalities clung to privileges granted by them, the fueros played an important role in the political, administrative, and judicial history of Spain.

363 The first Statute of Autonomy of Catalonia was enacted in 1932 (Generalitat of Catalonia Official Gazette, n. 19, 15 October 1932) which remained in force until 1938.

364 Constitution, BOE n. 311, 29 December 1978, pp. 29313-29424.

365 Constitution, BOE n. 311, 29 December 1978, pp. 29313-29424, Article 2. The original Spanish text reads as follows: "La Constitución se fundamenta en la indisoluble unidad de la Nación española, patria común e indivisible de todos los españoles, y reconoce y garantiza el derecho a la autonomía de las nacionalidades y regiones que la integran y la solidaridad entre todas ellas" (English translation GMG). Notice the use of the terms "nacionalidades y regiones" in the original Spanish text. Generally speaking, the term nationalities indicates territories whose inhabitants have a strong historically-constituted sense of identity, or, more specifically, certain autonomous communities whose Statutes of autonomy recognizes their historical and cultural identity. The use of such a terminology was the subject of heated discussions during the constitutional debate in the Spanish Parliament. Entrena Cuesta classifies the 
Catalonia enacted its Statute of Autonomy in 1979 which had the effect of restoring the Catalan Parliament and Government. ${ }^{366}$ Moderate nationalist parties then governed the Catalan institutions. In 2006, a new Statute of Autonomy was enacted ${ }^{367}$ which was the result of a reformist process. The purpose of this new Statute of Autonomy was to expand the Catalan competences to the maximum allowed by the Spanish Constitution and to provide for a better recognition of their specific "realitat nacional de Catalunya com a nacionalitat" (the national reality of Catalonia as a nationality). The new Statute of Autonomy was challenged before the Spanish Constitutional Court and was declared partially unconstitutional in 2010. ${ }^{368}$ This ruling, together with the Supreme Court decision

different positions that could be observed during that debate as follows: 1) Those being staunchly opposed to the term nationalities because it was considered ambiguous, discriminatory and dangerous (Senators Julian Marias and FernandezMiranda), confusing (MP Fraga Iribarne), unnecessary (Senators Lorenzo MartínRetortillo and Cela) and even inadequate (MP Gaston Sanz). This was the position of the Popular Alliance and some independent senators. 2) On the other end of the spectrum were the extreme nationalists, who supported the idea of removing the word nation since they understood that Spain was not a nation but a State formed by a group of nations (MP Barrera and Letamendía and Senators Bandrés and Xirinacs). 3) A variety of intermediate positions. See Rafael Entrena Cuesta in Fernando Garrido Falla et al, Comentarios a la Constitutición, Civitas, Madrid, 1985, pp. 43-44.

366 Organic Law 4/1979, 18 December, enacting the Statute of Autonomy of Catalonia, Generalitat of Catalonia Official Gazette, n. 38, 31 December 1979, pp. 576-594.

367 Organic Law 6/2006, 20 July, amending the Statute of Autonomy of Catalonia, Generalitat of Catalonia Official Gazette, n. 4680, 20 July 2006, pp. 31875-31936.

368 STC 31/2010, 28 June, BOE, n. 172, 16 July 2010, pp. 1-491. The Constitutional Court declared in this ruling that the interpretation of the references to "Catalonia as a nation" and to "the national reality of Catalonia" in the preamble of the Statute of Autonomy of Catalonia have no legal effect. Furthermore it declared unconstitutional, and consequently null and void the following parts of the Statute of Autonomy of Catalonia: the expression "and preferential" in Article 6.1; Article 76.4; the phrase "exclusively" Article 78.1; Article 97; Articles 98.2, (a), (b), (c), (d) and (e), and 98.3; the phrases "and with the participation of the Council of Justice of Catalonia" in Articles 95.5 and 95.6; the phrase "the President of the High Court of Catalonia, who chairs the Council" in Article 99.1; Article 100.1; the phrase "or the Council of Justice of Catalonia" in Articles 101.1 and 101.2; the phrase "as principles or lowest common legislative denominators in rules of legal rank, with the exception of those circumstances determined by the Constitution and this Statute of Autonomy" in Article 111; the phrase "the principles, rules and minimum standards established" in Article 120.2; the phrase "the principles, rules and minimum standards established" in Article 126.2; the phrase "provided that they also make a similar fiscal effort" in Article 206.3; and the phrase "may include the legislative capacity to establish and regulate local government taxes" in Article 218.2. Finally, the Constitutional Court did not find unconstitutional certain provisions of the Statute of Autonomy of Catalonia that were also challenged if and when they are interpreted according to the reasoning made by the Constitutional Court. 
overruling Catalonia's established language policy in education, ${ }^{369}$ gave rise to a "bottom up process aimed at attaining independence for Catalonia, which became clearly visible in the protest march of 11 September 2012".370

After the early elections of November 2012,371 which resulted in a new Catalan Parliament with a clear majority of MPs supporting a referendum on independence, the $\mathrm{CIU}$ and $\mathrm{ERC}^{372}$ reached an agreement on the National Transition of Catalonia ${ }^{373}$ which aimed at ensuring the parliamentary stability of the Catalan Government. This legislative agreement had the effect of establishing a clear path towards determining the political future of Catalonia. In a plenary session of the Catalan Parliament on 23 January 2013, one of the first steps taken was the adoption of a Resolution approving the Declaration of Sovereignty and the Right to Decide of the People of Catalonia. ${ }^{374}$ On 8 March 2013, the Spanish Government challenged the Resolution before the Constitutional Court. By May 2013, the Court had decided on the temporary suspension of the Resolution, pending a definitive decision. ${ }^{375}$

369 STS 4276/2012, Section 4, 12 June 2012.

370 Montserrat Guibernau, "Prospects for an independent Catalonia", International Journal of Politics, Culture and Society, Vol. 27, 2014, p. 19.

371 See on the role of the Spanish Constitutional Court in the Catalan Independence process Guayasén Marrero González, "Catalonia's independence and the role of the Constitutional Court: recent developments",Tijdschrift voor Constitutioneel Recht, 2015, pp. 86-94. Notice that the analysis made of the role of Constitutional Court until the "participatory process" took place has been already published in this contribution to the Tijdschrift voor Constitutioneel Recht.

372 The CIU (centre-right nationalist) was the most popular party in the regional elections but failed to win the absolute majority it sought. The ERC (left nationalist and republican) came second in the poll. The CIU and ERC ran their electoral campaign on an independence agenda. After a round of meetings, both political forces reached a governance pact which translated into the mentioned Agreement on $\mathrm{X}$ legislature.

373 Acord X legislatura (Agreement on the X legislature), CIU and ERC, 19 December 2012. This agreement also envisaged the adoption of the 'Declaration of Sovereignty and the Right to Decide of the People of Catalonia' and the creation of the Advisory Council for the National Transition.

374 Resolution 5/X of the Parliament of Catalonia, adopting the Declaration of sovereignty and right to decide of the people of Catalonia (Resolución $5 / \mathrm{X} \mathrm{del}$ Parlamento de Cataluña, por la que se aprueba la Declaración de soberanía y del derecho a decidir del pueblo de Cataluña), Catalan Parliament Official Gazette, 23 January 2013.

375 Constitutional Court decision (Providencia), 7 May 2013, BOE, n. 112, 10 May 2013, p. 35359. The fact that the Constitutional Court agreed to hear the challenge was widely criticised: the eligibility of the Resolution to constitute the object of a constitutional proceeding was highly questionable given its marked political nature. 
In March 2014, the Constitutional Court issued its ruling, ${ }^{376}$ in which the challenge of the Spanish Government was partly upheld. Firstly, the Court considered that, despite its political nature, the Declaration had legal effects and the Court therefore allowed the challenge brought by the Spanish Government to proceed. Secondly, the Court held that the Declaration was unconstitutional and nullified the first point of the Declaration, which stated:

"Sovereignty. The people of Catalonia have, for reasons of democratic legitimacy, the nature of a sovereign political and legal subject". 377

According to the Court, Article 1, paragraph 2 of the Constitution vests national sovereignty exclusively in the Spanish people as "the perfect unit to hold constituent powers and, as such, constitute the basis of the Constitution, the Spanish legal order, and the source of any political power". ${ }^{378}$ As seen in the current constitutional order, it is only the Spanish People -exclusively and indivisibly- that are sovereign. No other subject, State body or any group of persons, can be endowed with sovereign status by a public power. An act issued by a public power that asserts "legal sovereign status" as a competence of the people of an Autonomous Community inevitably also denies national sovereignty, which according to the Constitution can only be held by the entire Spanish people. Thus, sovereignty cannot be entrusted to any group or part thereof. The Court therefore concluded that:

"A recognition of sovereign status in favour of the people of Catalonia, which is not contemplated in the Spanish Constitution for nationalities and regions covered by the State, is incompatible with Article 2 of the Spanish Constitution; the partial subject that is entrusted with this power would be therefore able, at its discretion, to breach what the Constitution has declared as a based principle: 'the indissoluble unity of the Spanish Nation'. (...) It may therefore be inferred that in the constitutional order an Autonomous Community may not unilaterally

376 STC 42/2014, 25 March, BOE, n. 87, 10 April 2014, pp. 77-99. See on this Constitutional Court decision Víctor Ferreres Comella, "The Spanish Constitutional Court Confronts Catalonia's "Right to Decide" (Comment on the Judgment 42/2014)", European Constitutional Law Review, 2014, p. 590. See also Pablo José Castillo Ortiz, "Framing the Court: Political Reactions to the Ruling on the Declaration of Sovereignty of the Catalan Parliament", Hague Journal on the Rule of Law, 7 (1), 2015, pp. 27-47.

377 English text as provided in the English version of the Resolution 5/X of the Parliament of Catalonia, adopting the Declaration of sovereignty and right to decide of the people of Catalonia available at http://www.parlament.cat/document/ intrade/7176.

378 English translation GMG. 
hold a referendum of self-determination in order to decide on its integration in Spain". ${ }^{379}$

Notwithstanding, the Court simultaneously recognised that Catalan citizens' right to decide is in accordance with the Constitution insofar as it does not amount to self-determination. The right to self-determination is not recognised in the Constitution. The Court asserted that the right to decide is "a political aspiration" which can only be achieved through a constitutionally sound procedure, which respects the principles of "democratic legitimacy, pluralism and legality".

As expected, the decision was not well received amongst the political parties striving for Catalan independence. However, Catalonia's National Transition machinery continued while the ruling of the Constitutional Court was pending. In December 2013, the President of Catalonia announced that the four pro-independence political parties had reached an agreement regarding the questions and the date on which the independence referendum would be held. One month later, the Catalonian Parliament made a formal petition asking the Spanish Parliament to transfer the necessary powers required to hold a referendum. ${ }^{380}$ On April 2014, following a seven-hour parliamentary debate, the act was rejected by an overwhelming majority of the Parliament. In this vote, $86 \%$ of all Spanish MPs voted against the transfer of the powers, agreeing that the Spanish Constitution did not give Catalonia the right to hold such a referendum.

Another option under consideration was for Catalonia's legislative assembly to pass its own law allowing for regional consultations. This route had already been foreseen in the first report of the Advisory Council for the National Transition, ${ }^{381}$ which endorsed the recommendations of the Institute of Autonomic Studies of Barcelona. ${ }^{382}$ In July 2014, the

379 English translation GMG.

380 Resolution 479/X of the Parliament of Catalonia by which it was agreed to submit to the Presiding Board of the Congress the draft organic act delegating to the Generalitat of Catalonia the competence to authorise, call and hold a referendum on the political future of Catalonia (Resolución 479/X del Parlamento de Cataluña por la que se acuerda presentar ante la mesa del Congreso de los Diputados la proposición de ley orgánica de delegación en la Generalidad de Cataluña de la competencia para autorizar, convocar y celebrar un referéndum sobre el futuro político de Cataluña), Catalan Parliament Official Gazette, 16 January 2014.

381 Advisory Council for the National Transition,'The consultation on the political future of Catalonia', report n. 1, July 2013. Available at http://presidencia.gencat. cat/web/.content/ambits actuacio/consells assessors/catn/informes/inf 1 angles.pdf.

382 Institute of Autonomic Studies of Barcelona, 'Report on legal procedures by which 
corresponding parliamentary committee approved the first draft of the "Law on popular non-referendum consultations and civic participation". ${ }^{383}$ Before its definitive approval by the Catalan Parliament in plenary session, the draft was sent to the Catalan Council for Statutory Guarantees -the body in charge of assessing the compatibility of new Catalan legislation with the Catalan Statute of Autonomy and the Spanish Constitution. In a previous opinion, ${ }^{384}$ the Council established that any consultation held by the Catalan institutions regarding self-government would have to fall within the field of competences of the Catalonian Parliament. ${ }^{385}$ Notwithstanding, the outcome of the opinion on that draft seemed to depart from the previous conclusion. While it is true that Autonomous Communities can develop ways to improve democracy and civic participation in politics (when this is foreseen in their Statutes of Autonomy) the aim of the law was questionable from a constitutional perspective. The Council asserted that the draft was compliant with the Statute of Autonomy and the Spanish Constitution, but four dissenting opinions were attached to the opinion. ${ }^{386}$

On 19 September 2014, the Catalan Parliament approved the law that provided the legal basis for the Decree calling the consultation on independence for Catalonia. The Law entered into force on 27 September 2014 following its publication in the Catalan Official Gazette (Diari Oficial de la Generalitat de Catalunya). The President of the Catalan Government, Artur Mas, signed the Decree on the very same day ${ }^{387}$ which formally called

the citizens of Catalonia can be viewed on their collective political future' [Informe sobre els procediments legals a traves dels quals els ciutadans i les ciutadanes de Catalunya poden ser consultats sobre llur futur politic collectiu], 11 March 2013. Available at http://www20.gencat.cat/docs/governacio/IEA/documents/ Dret $\% 20 \mathrm{a} \% 20$ decidir/Arxius/Informe $\% 20$ consultes CAT.pdf.

383 Law 10/2014, 26 September, on popular non-referendum consultations and civic participation (Ley 10/2014, de 26 de septiembre, de consultas populares no refrendarias y otras formas de participación ciudadana), Generalitat of Catalonia Official Gazette, n. 6715, 27 September 2014.

384 Catalan Council for Statutary Guarantees (Consell de Garanties Estatutàries de Catalunya/ Consejo de Garantías Estatutarias de Cataluña), Opinion 15/2010 regarding the proposal for consultation by way of referendum on the independence of the Catalan nation (Dictamen 15/2010 respecte a la Proposta de consulta popular per via de referèndum sobre la independència de la nació catalane), 6 July 2010.

385 Elisenda Casana Adam, "The Independence Referendum and Debates on Catalonia's Constitutional Future", Tijdschrift voor Constitutioneel Recht, 2014, p. 167.

386 Catalan Council for Statutory Guarantees, Opinion 19/2014 on the draft law on popular non-referendum consultations and civic participation (Dictamen del Consell de Garanties Estatutàries 19/2014 sobre la Proposició de llei de consultes populars no referendàries i d'altres formes de participació ciutadana), 19 August 2014.

387 Decree 129/2014, 27 September, calling the non referendum and civic consultation on political future of Catalonia (Decreto 129/2014, de 27 de septiembre, de 
the consultation on independence to take place on 9 November 2014. Although no reference to the word referendum was made, the consultation had all the characteristics of a referendum. ${ }^{388}$

Unsurprisingly, on 29 September 2014, the Spanish Government filed two appeals before the Constitutional Court; one against the 9 November self-determination vote Decree and the second opposing the Catalan Parliament's law upon which it was based. The twelve members of the Constitutional Court voted unanimously to accept the arguments raised by the Spanish Government and consequently the Court suspended both the law and the decree pending the outcome of the appeal as well as the "remaining preparative acts for the calling of the said consultation or any others linked to it". ${ }^{389}$

Political reactions to the Court's judgment came swiftly. On 4 October 2014, 920 out of the 946 municipalities in Catalonia passed motions in favour of the independence vote on 9 November, and the Mayors of those municipalities met in Barcelona to show their support for the National Transition process. The Catalan Parliament then decided to start legal proceedings, requesting that two of the twelve members of the Constitutional Court be prevented from participating in the debates due to their association with the political party running the Spanish Government. Simultaneously, the Spanish Government announced the extension of the appeals against the Law and the Decree to the election of the members of a Control Commission approved by the Catalan Parliament and ratified by the Catalan President, despite the Constitutional Court having temporarily suspended the law on which it was based. ${ }^{390}$

convocatoria de la consulta popular no referendaria sobre el futuro político de Cataluña), Generalitat of Catalonia Official Gazette, n. 6715, 27 September 2014.

388 Javier López Hernández, "A Catalan perspective: franchise in a forbidden referendum", Kick-off contribution, European University Institute, Robert Schuman Centre for Advanced Studies, Florence, 2014, p. 10.

389 The Constitutional Court issued the rulings on 25 February 2015. In the ruling, dealing with the Law 10/2014, 26 September, on popular non-referendum consultations and civic participation the challenge was partly upheld and several provisions of the law were declared unconstitutional (see STC 31/2015, 25 February, BOE, n. 64, 16 March 2015, pp. 190-212). The second ruling (STC $32 / 2015$ ) declared void and unconstitutional the Decree 129/2014, 27 September, calling the non referendum and civic consultation on political future of Catalonia (see STC 32/2015, 25 February, BOE, n. 64, 16 March 2015, pp. 213-227).

390 Decree 132/2014, 2 October, appointing members of Control Commission on non referendum and civic consultation (Decreto 132/2014, de 2 de octubre, de nombramiento de los miembros de la Comisión de Control de las Consultas Populares no Refrendarias), Generalitat of Catalonia Official Gazette, n. 6720A, 3 October 2014. 
On 14 October 2014, Artur Mas announced that the consultation on $9^{\text {th }}$ November would not be held as planned, i.e. using the legal basis suspended by the Constitutional Court. The lack of sufficient legal guarantees was pointed out as one of the main reasons for ruling out the consultation route. ${ }^{391}$ However, he assured the public that polling stations and ballot boxes would be open on that day, thus allowing the Catalan people to vote and decide on the future of Catalonia.

The alternative vote announced by the Catalan Government was different from the original referendum plan. It aimed to be more of a survey without any legal implications. There was no official electorate census, but the questions remained the same: "Do you want Catalonia to be a State?", if the answer is yes, "Do you want that State to be independent?". ${ }^{392}$ This new and alternative poll, which has been called a "participatory process" (proceso participativo), had an unclear legal basis. Only a webpage launched by the Catalan Government ${ }^{393}$ provided information about this process. But the apparent lack of any legal basis was no an obstacle for the Spanish Government to appeal before the Constitutional Court against the "participatory process" that had been filed on 31 October 2014, the day after the receipt of the report from the State Council. ${ }^{394}$ On 4 November

391 See the official press release from Artur Mas available at http://premsa.gencat.cat/ pres fsvp/AppJava/notapremsavw/276423/ca/president-mas-9-locals-obertsurnes-paperetes-comprometre.do.

392 See Article 3 of the Decree 129/2014, 27 September, calling the non referendum and civic consultation on the political future of Catalonia (Decreto 129/2014, de 27 de septiembre, de convocatoria de la consulta popular no referendaria sobre el futuro político de Cataluña), Generalitat of Catalonia Official Gazette, n. 6715, 27 September 2014.

393 www.participa2014.cat

394 The Spanish Government first required an opinion from the Permanent Commission of the State Council (Comisión Permanente del Consejo de Estado). The request was made on 27 October, and the opinion was delivered three days later. The State Council, after analysing the renewed plan for 9 November reached the conclusion that its characteristics were essentially the same as the previous consultation, and recommended the Spanish Government to initiate the appropriate constitutional proceedings and request its suspension. According to the opinion, the power to call any kind of consultation via referendum about political decisions of particular importance "fall to the King, via a proposal made by the Prime Minister of the government, and previously authorised by the Congress of Deputies. In no case, as such, does an autonomous region have the power to do so" (English translation GMG). See the Permanent Commission of the State Council, dossier n. 1092/2014, Opinion establishing the challenge before the Constitutional Court of the actions of the Government of Catalonia for calling the Catalans and Catalan residents to express their views on the political future of Catalonia the day November 9 through a so-called citizen participation process (Propuesta de Acuerdo por el que se plantea impugnación ante el Tribunal Constitucional en relación con las actuaciones de la 
2014, the Constitutional Court voted unanimously to accept the appeal and to suspend the participatory process. ${ }^{395}$

Following the suspension of the "participatory process", the Catalan Government announced, after asserting that it would maintain the alternative vote despite the ruling of the Constitutional Court, that it would initiate legal action against the central government. A legal complaint was filed before the Supreme Court against the decision of the Spanish Cabinet of Ministers to file the new appeal. ${ }^{396}$ The main argument underpinning the complaint was that the Spanish Government had disrespected the basic rights and freedoms of the Catalan people, inter alia, the freedom of expression, the right to political participation, and the freedom of ideology. The Supreme Court declared the appeal inadmissible, stipulating that the agreement of the Cabinet of Ministers cannot be the subject of legal proceedings. ${ }^{397}$

Despite the Constitutional Court's decision, more than two million people cast their vote on 9 November 2014. According to the data released by the Catalan Government, more than $80 \%$ of the participants voted for the secessionist option (yes-yes). The federal route (yes-no) obtained $10.02 \%$, while the status quo option (no-no) was supported by $4.49 \%$ of the voters. ${ }^{398}$

Generalidad de Cataluña relativas a la convocatoria a los catalanes, las catalanas y las personas residentes en Cataluña para que manifiesten su opinión sobre el futuro político de Cataluña el dia 9 de noviembre mediante un denominado "proceso de participación ciudadana), 30 October 2014.

395 The Constitutional Court issued its ruling in June 2015 (STC 138/2015, 11 June, $B O E$, n. 160 , 6 July 2015, pp. 56313-56327). All the actions undertaken by the Generalitat regarding the participatory process, all the preparative acts for the calling of the consultation, and all acts linked to that consultation were declared unconstitutional.

396 Administrative appeal 905/20014 (Recurso contencioso-administrativo) submitted on 4 November 2014 by the Attorney of the Generalitat of Catalonia. See Supreme Court decision 10383/2014 (Auto), 6 November 2014, Administrative Chamber n. 7.

397 Supreme Court decision 10383/2014 (Auto), 6 November 2014, Administrative Chamber n. 7. See also the Supreme Court official press release, 6 November 2014, available at http://www.poderjudicial.es/cgpj/es/Poder-Judicial/TribunalSupremo/Noticias-Judiciales/-El-Tribunal-Supremo-inadmite-el-recurso-de-laGeneralitat-contra-la-impugnacion-de-la-celebracion-de-la-consulta.

398 See the official press release of the Catalan Government (Generalitat de Catalunya) on the results of the participatory process, available at http://premsa.gencat.cat/ pres fsvp/AppJava/notapremsavw/277932/ca/vicepresidenta-govern-presentaels-resultats-definitius-proces-participacio-ciutadana-9-novembre.do and the official report on the final result of the the participatory process, "9N-2014, Tu hi participes, tu decideixes" resultats definitius, Generalitat de Catalunya, available at 
The Attorney General's Office considered taking legal action against the Catalan officials in connection with the vote, especially in terms of the alleged misappropriation of funds and disobedience. ${ }^{399}$ On the Catalan side, the idea of calling new and early Catalan elections seemed the most likely option. However, the disagreement over the need for independence caused a rift in Catalan politics and led to the breakup of Convergència I Unió, the coalition that had ruled the region, almost uninterruptedly, for 37 years. Artur Mas began a round of negotiations with Catalan political parties in order to bring together all pro-independence forces on to a joint list Uunts pel Si). ${ }^{400}$ In doing so, the regional elections became a de facto popular plebiscite. On 3 August 2015, the Catalan President signed a decree calling for regional elections that were ultimately held on 27 September 2015.401 The word "plebiscite" was not included in the decree in order to avoid a further legal challenge from the central government.

With a turnout of $77.44 \%$, Junts pel Sí won 62 seats in the Catalan Parliament (the absolute majority is set at 68 out of a total of 135 seats). Thus, the support of CUP, ${ }^{402}$ the other secessionist contender in the

http://premsa.gencat.cat/pres fsvp/docs/2014/12/01/18/37/0370f7ca-397d43fa-8466-2c448ec4621d.pdf.

399 Catalonia's Supreme Court accepted on 5 January 2015 the criminal complaints filed against the President of the Catalan Government, Artur Mas, Vice President, Joana Ortega, and Catalan Minister for Education, Irene Rigau for having authorised and co-organised the non-binding and symbolic vote on independence that took place on 9 November 2014 in public venues throughout Catalonia. The decision of the Supreme Court is still pending.

400 Artur Mas, leader of Convergència, ran the joint list known as Junts pel Sí (Together for yes), along with the Catalan Republican Left (ERC) and other pro-independence groups and civic associations. The coalition was officially presented on 20 July 2015 at the Catalan History Museum in Barcelona. Junts pel Sí leading candidate, Raül Romeva, explained the steps to be taken after the elections if the pro-independence forces were to secure an absolute majority in the Catalan Parliament. The first step would be for the Catalan Parliament to declare the beginning of the secession process. After that, the legislature would give the executive the power to activate "State structures." The third step would be to draft a Catalan Constitution and after voting on it, there would be a formal declaration of independence. Within 18 months, the government would dissolve and new constituent elections would be called.

401 Decree 174/2015, 3 August, calling elections to the Catalan Parliament and its dissolution (Decreto 174/2015, de 3 de agosto, de convocatoria de elecciones al Parlamento de Cataluña y de su disolución), BOE, n. 185, 4 August 2015, p. 69731.

402 Candidatura d'Unitat Popular (Popular Unity Candidacy) is a left-wing Catalan party which definies itself as an "assembly style political organization, established in the Catalan Countries, which aims for an independent, socialist, ecologically sustainable, regionally balanced and detached from forms of patriarchal domination Catalan State". See CUP's website: http://cup.cat/qui-som. 
elections that had 10 seats, was needed to secure the absolute majority of secessionist forces in the regional assembly. However, although the proindependence political parties won the most seats, they did not win the most votes. Junts pel Sí and CUP received $47.74 \%$ of the votes $(39.54 \%$ and $8.20 \%$ respectively) while the non-secessionist options received $48.11 \%$ of the votes. ${ }^{403}$

On 27 October 2015, one day after the new Catalan Parliament was constituted, the parliamentary groups of Junts pel Sí and CUP submitted a motion for a resolution to the Catalan Parliament Board urging it to "solemnly declare the beginning of the creation process of an independent Catalan republic". ${ }^{04}$ The resolution was adopted on 9 November 2015 with 72 votes in favour (Junts pel Sí and CUP) and 63 votes against (Ciudadanos, PSC, PP and Catalunya Sí que es Pot). ${ }^{405}$ On 11 November 2015, the Spanish Government challenged the Resolution before the Constitutional Court. On 2 December 2015, the Constitutional Court declared the Resolution unconstitutional and nullified the Declaration accordingly. ${ }^{406}$

The new Catalan President, Carles Puigdemont i Casamajó, was officially sworn in on 12 January 2016, after the cumbersome process of forming a new Catalan Government. During that period, Spanish general elections were held on 20 December 2015 to elect a new Spanish Parliament (Cortes Generales). The election resulted in the most fragmented Spanish parliament in recorded history, ${ }^{407}$ making the formation of a new

${ }^{403}$ See the official report of the Catalan Government (Generalitat de Catalunya) on the results of the regional elections in Catalonia, "27S-2015, Eleccions al Palament de Catalunya, Final Results Report", Generalitat de Catalunya, available at http:// resultats.parlament2015.cat/09pdf/C09-DOSSIER L4.pdf.

404 Motion for resolution on the beginning of a political process in Catalonia linked to the results of the elections (Proposta de resolució sobre l'inici del procés polític a Catalunya com a conseqüència dels resultats electorals), Catalan Parliament Official Gazette (Butlletí Oficial del Parlament de Catalunya), 27 October 2015. The original text reads as follows: "declara solemnement l'inici del procés de creació de l'estat català independent". The full text is available in the Catalan language at http:// www.parlament.cat/document/bopc/152861.pdf.

405 Resolution 1/XI of the Parliament of Catalonia, on the beginning of a political process in Catalonia linked to the results of the 27 September 2015 elections (Resolució 1/XI del Parlament de Catalunya, sobre l'inici del process polític a Catalunya com a conseqüència dels resultats electorals del 27 de setembre de 2015), Catalan Parliament Official Gazette (Butlletí Oficial del Parlament de Catalunya), 9 November 2015.

406 STC 259/2015, 2 December, BOE, n. 10, 12 January 2016, pp. 1951-1971.

407 The Popular Party (PP) won the election with 123 seats (out of 350 seats) in Congress, the Socialist Party (PSOE) came in second with 90 representatives, Podemos won 69 deputies ( 42 deputies together with 27 seats from the regional brands of Podemos), Ciudadanos came in fourth with 40 seats, while the Izquierda 
government impossible. ${ }^{408}$ The power vacuum in Madrid did not stifle the pro-independence momentum in Catalonia. The new Catalan President made his position clear during the swearing-in ceremony: he was sworn in as President of the Generalitat of Catalonia vowing loyalty to the people of Catalonia but not to the Spanish Constitution or the King. ${ }^{409}$ During the first plenary session of the new Catalan Government, Carles Puigdemont committed himself to achieving Catalonian/Catalan independence within 18 months to respond to the democratic mandate expressed in the Catalan Elections of 27 September 2015 and to starting the "disconnection process" from Spain. ${ }^{410}$

One of the first decisions taken by Carles Puigdemont was the creation of a Catalan Foreign Affairs Department. The Decree that created the "Departament d'Afers Exteriors, Relacions Institucionals i Transparència" was signed on 13 January 2016.111 As could be expected, the Spanish Government filed an appeal before the Constitutional Court against the Decree, considering that the Catalan Government exceeded the competences in matters of foreign affairs specified in the Catalan Statute of Autonomy. Furthermore, the appeal was extended to the Decree establishing the structure of the Foreign Affairs Department. ${ }^{412}$ On 16

Unida managed to gain two seats. Regarding regional parties, the Catalan Republican Left (ERC) obtained nine seats, while Democracia y Llibertat, the new brand led by Catalan premier Artur Mas, won eight. The Basque Nationalist Party (PNV) gained six seats and Bildu obtained two. The Canaries Coalition got one seat. With such a fragmented parliament, forming a government became a particularly difficult task. On the Spanish general elections results see the oficial webpage of the Ministry of Internal Affairs: https://resultadosgenerales2015.interior.es/\#/.

408 Faced with the impossibility of forming a coalition government, new general elections were called and held on 26 June 2016. The new Spanish Gavernment took office on 26 October 2016.

409 Minutes of swearing-in ceremony of the Most Honourable Carles Puigdemont i Casamajó as President of the Generalitat of Catalonia (Acta de presa de possessió del Molt Honorable Senyor Carles Puigdemont i Casamajó de la Presidència de la Generalitat de Catalunya), Catalan government Official Gazette (Diari Oficial de la Generalitat de Catalunya), No. 7036, 13 January 2016, pp. 1-2.

410 See official press release of the Catalan Government (Generalitat de Catalunya), available at http://premsa.gencat.cat/pres fsvp/App/ava/oficina-president/ notapremsavw/290158/ca/president-puigdemont-nou-govern-renunciara-res-ifara-coses-maxim-be-dexplicades-dimplicades-possible.do.

411 Decree 2/2016, 13 January, on the creation, designation and determination of the scope of competence of the government departments of the Generalitat of Catalonia (Decret 45/2016, de 19 de gener, d'estructuració del Departament d'Afers Exteriors, Relacions Institucionals i Transparència), Generalitat of Catalonia Official Gazette, n. 7041, 20 January 2016.

412 Decree 45/2016, 19 January, establishing the structure of the Department of Foreign Affairs, Institutional Relations and Transparency (Decret 2/2016, de 13 de gener, de 
February 2016, the Court issued its decision to accept the appeal and suspended several provisions of both Decrees ${ }^{413}$ until the final Court decision would be taken. ${ }^{414}$ Anticipating the decision of the Constitutional Court on this issue, the Catalan Government decided to modify the denomination of this department from "Departament d'Afers Exteriors, Relacions Institucionals i Transparència" to "Departament d'Afers $i$ Relacions Institucionals i Exteriors i Transparència". ${ }^{415}$ On 21 June 2016 the Court ruled on the suspended provisions, ${ }^{416}$ lifting the suspension except in the subsections where "Foreign Affairs" was mentioned. According to the Court, using that expression

"[e]ven if it is a simple denomination, it coincides with the name of a Ministerial Department of the Central Government which exercises powers of the State (...). It is for this reason that this denomination may confer to the Department that creates art. 1.1 of Decree 2/2016 the appearance of being an international actor with powers that in this area belong only to the State, and consequently, could pursue the objective of endowing the Generalitat de Catalunya with competences that exceed those corresponding to it according to its Statute of Autonomy". 417

creació, denominació i determinació de l'àmbit de competència dels departaments de l'Administració de la Generalitat de Catalunya), Generalitat of Catalonia Official Gazette, n. 7037, 14 January 2016.

413 The interim suspension affected Articles 1.1, 3.3.1 and 3.3.2 of the Decree 2/2016 and Articles 1.1.b and 20 of the Decree 45/2016.

${ }^{414}$ SeeConstitutional Court decision (Providencia) 16February 2016 available athttp:// www.tribunalconstitucional.es/es/salaPrensa/Documents/NP 2016 010/P\%20 672-2016.pdf. See also BOE, n. 43, 19 February 2016, p. 12931 and Catalan Government Official Gazette (Diari Oficial de la Generalitat de Catalunya), No. 7048, 29 January 2016, pp. 1-2.

415 Decree 212/2016, 1 March, adding a transitory provision to the Decree 2/2016, 13 January, on the creation, designation and determination of the scope of competence of the government departments of the Generalitat of Catalonia (Decret 212/2016, d'1 de març, pel qual s'afegeix una disposició transitòria al Decret 2/2016, de 13 de gener, de creació, denominació i determinació de l'àmbit de competència dels departaments de l'Administració de la Generalitat de Catalunya), Generalitat of Catalonia Official Gazette, n. 7073, 7 March 2016. See also the official press release of the Generalitat of Catalonia, available at http://premsa.gencat.cat/ pres fsvp/AppJava/notapremsavw/291130/ca/govern-mante-terme-afers-nomdepartament-conseller-romeva.do.

416 Auto 130/2016, 21 June, BOE, n. 158, 1 July 2016, p. 46803.

417 Auto 130/2016, 21 June, BOE, n. 158, 1 July 2016, p. 46803, seventh paragraph of the assessment by the Court (fundamento jurídico séptimo). English translation GMG. 
The disconnection process from Spain was strengthened with the presentation of three legislative proposals by Junts Pel Sí and CUP in the Catalan Parliament: one on social measures, a second on the Catalan tax office and a third on the legal transition towards an independent Catalan State. ${ }^{418}$ As could be expected, the adoption of these proposals led to new legal challenges before the Constitutional Court. ${ }^{419}$

On 1 February 2016, the Spanish (caretaker) Government challenged the Catalan Parliament's Resolution $5 / \mathrm{XI}^{420}$ before the Constitutional Court. This resolution established several parliamentary commissions, among them the so-called Commission to Study the Constituent Process (Comissió d'Estudi del Procés Constituent). The Court upheld the challenge ${ }^{421}$ and, in its decision, stated that the area of action of that Commission matched with the purposes of the already declared unconstitutional Resolution 1/ $\mathrm{XI}^{422}$ However, the Court did not declare the nullity of the Resolution 5/ $\mathrm{XI}$ in relation to the creation of the Commission, since it was considered that the activity of that Commission was capable of being "directed" to the legitimate aim of analysing possible alternatives to carry out constitutional reforms in accordance with the Constitution. ${ }^{423}$ The Court emphasised that the work of that Commission shall be conditioned to the fulfilment of

418 See official press release of the Catalan Parliament, available at http:// www.parlament.cat/web/actualitat/noticies/index.html?p format=D\&p $\underline{i d}=270144247$.

419 During 2016, the Spanish Government challenged before the Constitutional Court, inter alia, the Law 16/2015, 21 July, simplifying the administrative activity of the Generalitat and local governments of Catalonia and spurring economic activity [(Llei 16/2015, del 21 de juliol, de simplificació de l'activitat administrativa de l'Administració de la Generalitat i dels governs locals de Catalunya i d'impuls de l'activitateconòmica), Generalitat of Catalonia Official Gazette, n. 6920, 24 July 2015]; the Law 17/2015, 21 July, on equality between women and men [(Llei 17/2015, del 21 de juliol, d'igualtat efectiva de dones i homes), Generalitat of Catalonia Official Gazette, n. 6919, 23 July 2015]; and the Law 24/2015, 29 July, on urgent measures to deal with emergency situations regarding housing and energy poverty [(Llei 24/2015, del 29 de juliol, de mesures urgents per a afrontar l'emergència en l'àmbit de l'habitatge i la pobresa energètica), Generalitat of Catalonia Official Gazette, n. 6928, 5 August 2015].

420 Resolution 5/XI of the Parliament of Catalonia creating parliamentary commissions (Resolució 5/XI del Parlament de Catalunya, de creació de comissions parlamentàries), Catalan Parliament Official Gazette (Butlletí Oficial del Parlament de Catalunya), 25 January 2016.

421 Auto 141/2016, 19 July, BOE, n. 196, 15 August 2016, pp. 60631-60646.

422 See Auto 141/2016, 19 July, BOE, n. 196, 15 August 2016, pp. 60631-60646, sixth and seventh paragraphs of the assessment by the Court (fundamentos jurídicos sexto y séptimo).

${ }^{423}$ See Auto 141/2016, 19 July, BOE, n. 196, 15 August 2016, pp. 60631-60646, seventh paragraph of the assessment by the Court (fundamento jurídico séptimo). 
the requirements of the Constitution and, in particular, of the procedures for its reform. An important caveat is that it was not constitutionally admissible that 'the parliamentary activity of 'analysis' or 'study' continues and supports the objective proclaimed in the resolution l/XI -the beginning of the creation process of an independent Catalan republic- which was declared unconstitutional".

At the time of issuing its ruling, the Constitutional Court had knowledge of a report from the Commission to Study the Constituent Process ${ }^{425}$ whose content "clearly contravenes" 426 the Court's mandate regarding the avoidance of any activity in line with the objective of the Resolution $1 / \mathrm{XI}$. Thus, in its decision, the Court reminded the authorities involved, in particular the Board of the Parliament, of their duty to prevent any initiative ignoring or circumventing its mandate.

On 27 July 2016 and despite the mentioned Constitutional Court decision, the Catalan Parliament endorsed ${ }^{427}$ the report from the Commission to Study the Constituent Process in which it was concluded, inter alia, that

"Currently, there is no margin of action for the recognition of the right to decide of the Catalan people within the Spanish constitutional and legal framework. The only possible way to exercise this right is through a disconnection process and the unilateral initiation of a Catalan constituent process". ${ }^{428}$

424 Auto 141/2016, 19 July, BOE, n. 196, 15 August 2016, pp. 60631-60646, seventh paragraph of the assessment by the Court (fundamento jurídico séptimo). English translation GMG.

425 Report of Commission to Study the Constituent Process (Informe de la Comissió d'Estudi del Procés Constituent), Catalan Parliament Official Gazette (Butlletí Oficial del Parlament de Catalunya), 20 July 2016.

426 Auto 141/2016, 19 July, BOE, n. 196, 15 August 2016, pp. 60631-60646, seventh paragraph of the assessment by the Court (fundamento jurídico séptimo).

427 Resolution 263/XI of the Parliament of Catalonia endorsing the report and the conclusions of the Commission to Study the Constituent Process (Resolució 263/ XI del Parlament de Catalunya, per la qual es ratifiquen l'Informe i les Conclusions de la Comissió d'Estudi del Procés Constituent), Catalan Parliament Official Gazette (Butlletí Oficial del Parlament de Catalunya), 1 August 2016.

${ }^{428}$ Report of Commission to Study the Constituent Process (Informe de la Comissió d'Estudi del Procés Constituent), Catalan Parliament Official Gazette (Butlletí Oficial del Parlament de Catalunya), 20 July 2016, concluding remark No. 1. The original text reads as follows: "Actualment, no hi ha cap marge d'acció pel reconeixement del dret a decidir del poble català en l'interior del marc jurídic constitucional i legal espanyol. L'única manera possible d'exercir aquest dret és per la via de la desconnexió $i$ l'activació unilateral d'un Procés Constituent propi". English translation GMG. Notice that in the text finally endorsed by the Catalan Parliament the word "unilateral" was removed from the concluding remark No. 1 . 
"The people of Catalonia have the legitimacy to begin their own citizen-based, transversal, participatory and binding constituent process, with the recognition, support and endorsement of the Catalan institutions" ${ }^{429}$

"The constituent process will consist of three phases: a first phase of participatory process, a second phase of disconnection from the Spanish State, in which a Constituent Assembly will be formed with the purpose of drafting a constitution, and a third phase for the popular ratification of the constitution via referendum". 430

Again, the Spanish (caretaker) Government challenged that Resolution before the Constitutional Court. The Court held that the conclusions reached by Commission to Study the Constituent Process were unconstitutional and nullified the Resolution in its entirety. ${ }^{431}$ The Court stressed that

"By approving these conclusions, the Catalan Parliament gives continuity and supports the purpose of the annulled resolution 1/XI, that is, the beginning of a constituent process in Catalonia, aimed at disconnecting from the Spanish State, drafting a Catalan constitution and creating an independent Catalan republic. The unconstitutionality of this purpose was firmly declared by STC 259/2015, which the Parliament of Catalonia cannot ignore, because the Chamber itself is bound by the Constitutional Court decision". ${ }^{432}$

429 Report of Commission to Study the Constituent Process (Informe de la Comissió d'Estudi del Procés Constituent), Catalan Parliament Official Gazette (Butlletí Oficial del Parlament de Catalunya), 20 July 2016, concluding remark No. 2. The original text reads as follows: "El poble de Catalunya té la legitimitat per a començar un Procés Constituent propi, de base ciutadana, transversal, participatiu i vinculant, amb el reconeixement, el suport i l'aval de les institucions catalanes". English translation GMG. Notice that in the text finally endorsed by the Catalan Parliament the word "democratic" was added from the concluding remark No. 2.

430 Report of Commission to Study the Constituent Process (Informe de la Comissió d'Estudi del Procés Constituent), Catalan Parliament Official Gazette (Butlletí Oficial del Parlament de Catalunya), 20 July 2016, concluding remark No. 4. The original text reads as follows: "El Procés Constituent constarà de tres fases: una primera fase de procés participatiu previ, una segona fase de desconnexió amb l'Estat i convocatòria d'una Assemblea Constituent que redacti un projecte de Constitució i una tercera fase de ratificació popular del text constitucional mitjançant referèndum". English translation GMG. Notice that in the text finally endorsed by the Catalan Parliament the numbering of the concluding remark was changed (from No. 4 to No. 5). Furthermore, some minor changes were added, inter alia, a reference to "constituent elections to form a constituent assembly" was introduced in the description of the second phase of the constituent process.

431 Auto 170/2016, 6 October, BOE, n. 276, 15 November 2016, pp. 79980-80012.

${ }_{432}$ See Auto 170/2016, 6 October, BOE, n. 276, 15 November 2016, pp. 79980-80012, 
Furthermore, the Court considered it necessary to notify its decision to the President of the Parliament of Catalonia personally, together with the rest of the members of the Board and the Secretary General of that Parliament, as well as the President and other members of the Catalan Government, warning them of their duty to refrain from carrying out any action aimed at complying with Resolution 263/XI, as well as their duty to prevent any initiative, legal or material, that directly or indirectly ignores the Court's decision. The Court also warned them of the possible responsibility, including criminal responsibility, which they could incur in case of noncompliance with its decision. In relation to the President of the Parliament of Catalonia, Carme Forcadell i Lluís, the Court decided to inform the Public Prosecutor in order to exercise, if appropriate, the corresponding actions before the competent court, regarding her possible liability in this case..$^{433}$ On 10 October 2016, the Public Prosecutor brought a criminal action before the High Court of Catalonia against the President of the Parliament of Catalonia. This Court accepted the complaint, opening the pre-trial phase for the alleged crimes of disobedience and malfeasance. ${ }^{434}$

In September 2016, Carles Puigdemont, the Catalan President, faced with the impossibility of reaching an agreement to approve the regional budget, asked the Catalan Parliament for a vote of confidence. The Parliamentary sessions took place on 28 and 29 September 2016. The majority of the Chamber gave its support to the President (72 in favour and 63 votes against renewing the confidence in Carles Puigdemont) ${ }^{435}$ who made it clear that a binding referendum will take place in Catalonia in

seventh paragraph of the assessment by the Court (fundamento jurídico séptimo). English translation GMG.

433 In its decision, the Constitutional Court noted that the President of the Parliament of Catalonia, Carme Forcadell i Lluís, allowed an alteration of the order of the day in the Parliamentary session, which finally led to endorsement of the report from the Commission to Study the Constituent Process. This "constitutes an objective breach of her duty to prevent any initiative ignoring or circumventing the mandates set forth in SSTC 259/2015 and ATC 141/2016; duty of which she was expressly warned, in her capacity as President of the Board of Parliament and under her responsibility, in the operative part of ATC 141/2016". See Auto 170/2016, 6 October, BOE, n. 276, 15 November 2016, pp. 79980-80012, eighth paragraph of the assessment by the Court (fundamento jurídico octavo). English translation GMG.

${ }^{434}$ See the official press release of the High Court of Catalonia, available at http:// www.poderjudicial.es/cgpj/es/Poder-Judicial/Tribunales-Superiores-de-Justicia/ TSJ-Cataluna/Noticias-Judiciales-TSJ-Cataluna/El-TSJ-de-Cataluna-admite-atramite-la-querella-contra-Carme-Forcadell.

435 See the minutes of the Parliamentary session on 29 September 2016, vote of confidence in the President of the Generalitat of Catalonia (Qüestió de confiança del president de la Generalitat), Catalan Parliament Session's Record (Diari de Sessions del Parlament de Catalunya), No. 37, 29 September 2016, pp. 80-83. 
the second half of September 2017. During his speech, he stated that

"We will work with the desire to hold a referendum agreed with the State, but if we reach the end of the term and there has been no positive response in this regard, we will be prepared and ready to take the last step to proclaim the effective independence of Catalonia and, at most, hold a referendum in the second half of September next year". ${ }^{436}$

He stressed that there is only one-way to resolve the Catalan demand: "It's either a referendum or a referendum. I repeat: It's either a referendum or a referendum".437

Once the vote of confidence was adopted, the pro-independence parliamentary groups of Junts pel Sí and CUP submitted a proposal for a resolution to the Catalan Parliament Board on the general political orientation of the Government of Catalonia. In the proposal, adopted on 6 October 2016, ${ }^{438}$ the Parliament "urges the Government to hold a binding referendum on the independence of Catalonia, at the latest, in September 2017, with a clear question and a binary answer" 439 and commits itself to provide the necessary legal coverage for that referendum, even without the agreement of the central government. ${ }^{440}$ Again, the Spanish Government challenged several provisions of the Resolution before the Constitutional Court and, again, the Court accepted the appeal and suspended those provisions until the final decision is taken. ${ }^{41}$ The Court also notified its

436 Minutes of the Parliamentary session on 28 September 2016, vote of confidence in the President of the Generalitat of Catalonia (Qüestió de confiança del president de la Generalitat), Catalan Parliament Session's Record (Diari de Sessions del Parlament de Catalunya), No. 36, 28 September 2016, p. 13. English translation GMG.

437 Minutes of the Parliamentary session on 28 September 2016, vote of confidence in the President of the Generalitat of Catalonia (Qüestió de confiança del president de la Generalitat), Catalan Parliament Session's Record (Diari de Sessions del Parlament de Catalunya), No. 36, 28 September 2016, p. 13. English translation GMG.

438 Resolution 306/XI of the Parliament of Catalonia on the general political orientation of the Government of Catalonia (Resolució 306/XI del Parlament de Catalunya, sobre l'orientació política general del Govern), Catalan Parliament Official Gazette (Butlletí Oficial del Parlament de Catalunya), 18 October 2016.

439 Resolution 306/XI of the Parliament of Catalonia on the general political orientation of the Government of Catalonia (Resolució 306/XI del Parlament de Catalunya, sobre l'orientació política general del Govern), Catalan Parliament Official Gazette (Butlletí Oficial del Parlament de Catalunya), 18 October 2016, p. 5.

440 Resolution 306/XI of the Parliament of Catalonia on the general political orientation of the Government of Catalonia (Resolució 306/XI del Parlament de Catalunya, sobre l'orientació política general del Govern), Catalan Parliament Official Gazette (Butlletí Oficial del Parlament de Catalunya), 18 October 2016, p. 5.

${ }_{441}$ Constitutional Court decision (Providencia), 13 December 2016, BOE, n. 302, 15 December 2016, pp. 87101-87102. 
decision to the President of the Parliament of Catalonia personally, together with the rest of the members of the Board and the Secretary General of that Parliament, as well as the President and other members of the Catalan Government, warning them of their duty to prevent any initiative, legal or material, that directly or indirectly ignores the Court's decision.

Table No. 1

\begin{tabular}{|c|c|}
\hline \multicolumn{2}{|c|}{ Milestones of the Catalan independence process } \\
\hline 1137 & Catalonia became part of the Crown of Aragon \\
\hline 1469 & Integration of the Crowns of Castile and Aragon \\
\hline 1716 & Abolishment of institutions, privileges and fueros \\
\hline $19^{\text {th }}$ Century & Renaixença \\
\hline October 1932 & First Statute of Autonomy of Catalonia \\
\hline $1936-1975$ & Francoism \\
\hline December 1978 & Spanish Constitution adopted \\
\hline December 1979 & $\begin{array}{l}\text { Statute of Autonomy of Catalonia, re-establishment of the } \\
\text { Catalan Parliament and Generalitat }\end{array}$ \\
\hline July 2006 & New Statute of Autonomy of Catalonia \\
\hline June 2010 & $\begin{array}{l}\text { The Constitutional Court declared the } 2006 \text { Catalan Statute } \\
\text { of Autonomy partially unconstitutional }\end{array}$ \\
\hline November 2012 & $\begin{array}{l}\text { Regional elections resulting in a new Catalan Parliament } \\
\text { with a majority of MPs supporting a referendum on } \\
\text { independence }\end{array}$ \\
\hline January 2013 & $\begin{array}{l}\text { Declaration of Sovereignty and the Right to Decide of the } \\
\text { People of Catalonia (challenged before the Constitutional } \\
\text { Court) }\end{array}$ \\
\hline December 2013 & $\begin{array}{l}\text { Agreement between the four pro-independence political } \\
\text { parties regarding the questions and the date of the } \\
\text { referendum }\end{array}$ \\
\hline January 2014 & $\begin{array}{l}\text { Formal petition to the Spanish Parliamentin order to transfer } \\
\text { the necessary powers required to hold a referendum }\end{array}$ \\
\hline March 2014 & $\begin{array}{l}\text { The Constitutional Court declared the unconstitutionality } \\
\text { and nullity of the first point of the Declaration }\end{array}$ \\
\hline April 2014 & $\begin{array}{l}\text { The Spanish Parliament voted against the transferring of } \\
\text { the powers }\end{array}$ \\
\hline September 2014 & $\begin{array}{l}\text { Law on popular non-referendum consultations and civic } \\
\text { participation (challenged before the Constitutional Court) } \\
\text { Decree calling the non referendum and civic consultation } \\
\text { on political future of Catalonia (challenged before the } \\
\text { Constitutional Court) }\end{array}$ \\
\hline
\end{tabular}




\begin{tabular}{|c|c|}
\hline October 2014 & $\begin{array}{l}\text { An alternative vote (the participatory process) was } \\
\text { announced (challenged before the Constitutional Court) }\end{array}$ \\
\hline November 2014 & $\begin{array}{l}\text { Participatory process suspended by the Constitutional } \\
\text { Court's decision of } 4 \text { November }\end{array}$ \\
\hline 9 November 2014 & Participatory process held \\
\hline 27 September 2015 & Regional elections \\
\hline November 2015 & $\begin{array}{l}\text { Resolution } 1 \text { / XI of the Parliament of Catalonia, on the } \\
\text { beginning of a political process in Catalonia linked to the } \\
\text { results of the } 27 \text { September } 2015 \text { elections (challenged } \\
\text { before the Constitutional Court) }\end{array}$ \\
\hline \multirow[t]{3}{*}{ January 2016} & New Catalan President is elected \\
\hline & $\begin{array}{l}\text { Creation of a Catalan Foreign Affairs Department } \\
\text { (challenged before the Constitutional Court) }\end{array}$ \\
\hline & $\begin{array}{l}\text { Creation of the Commission to Study the Constituent } \\
\text { Process (challenged before the Constitutional Court) }\end{array}$ \\
\hline February 2016 & $\begin{array}{l}\text { Catalan Foreign Affairs Department suspended by the } \\
\text { Constitutional Court }\end{array}$ \\
\hline 26 June 2016 & Spanish General Elections \\
\hline 20 July 2016 & Report of the Commission to Study the Constituent Process \\
\hline 27 July 2016 & $\begin{array}{l}\text { Resolution 263/XI of the Parliament of Catalonia endorsing } \\
\text { the report and the conclusions of the Commission to } \\
\text { Study the Constituent Process (challenged before the } \\
\text { Constitutional Court) }\end{array}$ \\
\hline 28-29 September 2016 & $\begin{array}{l}\text { Vote of confidence in the President of the Generalitat of } \\
\text { Catalonia. A binding referendum is announced to be held in } \\
\text { September } 2017\end{array}$ \\
\hline 6 October 2016 & $\begin{array}{l}\text { The Constitutional Court declared the unconstitutionality } \\
\text { and nullity of the Resolution 263/XI } \\
\text { Resolution 306/XI of the Parliament of Catalonia on the } \\
\text { general political orientation of the Government of Catalonia } \\
\text { (challenged before the Constitutional Court) }\end{array}$ \\
\hline 10 October 2016 & $\begin{array}{l}\text { Public Prosecutor brought a criminal action before the High } \\
\text { Court of Catalonia against the President of the Parliament } \\
\text { of Catalonia. Crimes of disobedience and malfeasance are } \\
\text { being investigated }\end{array}$ \\
\hline
\end{tabular}




\section{Flanders}

Belgium experienced its own process of independence from the Kingdom of the Netherlands in $1830 .{ }^{442}$ After the "Belgian Revolution" of August 1830 (which followed the July revolution in Paris that overthrew Charles $\mathrm{X}$ of France), a provisional Belgian Government was established on 25 September 1830. The newly elected National Congress ${ }^{443}$ convened in Brussels to proclaim the independence of the country on 18 November. Notwithstanding the attempts of the Netherlands to restore order in the Belgian provinces by appealing to the Great Powers, an armistice was imposed: ${ }^{444}$ Belgium was recognised as an independent State ${ }^{445}$ and Leopold of Saxe Coburg Gotha was appointed as the first King of the Belgians. $^{446}$

Unlike in Catalonia or Scotland, Flanders did not exist as an independent region before Belgium was created. The Flemish provinces were distinguishable, however, from neighbouring areas of the Low Countries due to their use of the Dutch language (which separated them from the French-speaking areas to the south) and adherence to Catholicism (which differentiated them from the Protestant Dutch-speaking areas to the north). After independence, the territories within the Belgian border

${ }^{442}$ From the sixteenth century until the French Revolution, the territories that eventually would make up Belgium consisted of an amalgamation of provinces, some Francophone and some Flemish, controlled first by the Spanish and later by the Habsburgs. As a result of the French Revolution, this territory was absorbed and controlled by France from 1797 untill 1814. After the fall of Napoleon in 1815, the Great Powers decided at the Vienna Congress to make Belgium part of the United Kingdom of the Netherlands, ruled by King William I of the House of Orange.

443 Elections took place in 3 November.

444 Protocole No. 1 de la Conférence, tenue au Foreign Office le 4 Novembre 1830, Article 2: "Pour accomplir leur résolution d arrêter l effusion du sang elles ont été $d$ avis qu une entière cessation d'hostilités devrait avoir lieu de part et $d$ autre. Les conditions de cet Armistice qui ne préjugerait en rien les questions dont les 5 Cours auront à faciliter la solution seraient telles qu elles se trouvent indiquées ci dessous".

445 Protocole No. 11 de la Conférence, tenue au Foreign Office le 20 Janvier 1831. "Dans ce but les Plénipotentiaires ont jugé indispensable de poser avant tout des bases quant aux limites qui doivent séparer désormais le Territoire Hollandais du Territoire Belge

I Les limites de la Hollande comprendront tous les Territoires Places Villes et Lieux qui apparteuoient à la ci devant République des Provinces Unies des Pays Bas en l année 1790

II La Belgique sera formée de tout le reste des Territoires qui avaient reçu la dénomination du Royaume des Pays Bas dans les Traités de l année 1 S15 saufle Grand Duché de Luxembourg qui possédé à un titre différent par les Princes de la Maison de Nassau fait et continuera à faire partie de la Confédération Germanique".

44621 July 1831 (coronation). 
showed a clear linguistic border separating the Dutch-speaking north (Flanders) from the French-speaking south (Wallonia). In the early period, the francophone minority dominated Belgium. French was the language of politics, commerce, and culture; and the capital, Brussels, gradually became a predominantly French-speaking city despite being located in Flanders. The mines and factories of Wallonia drove the Belgian economy and Belgium's wealth was concentrated in Brussels and the French-speaking region. In contrast, Flanders remained impoverished and predominantly agricultural.

The roots of Flemish nationalism can be traced back to the "Flemish Movement", which during the late nineteenth and early twentieth centuries sought greater equality in the area of language rights. The Belgian Government, under pressure from this movement, gradually extended the official use of Dutch in legal, educational, and administrative matters. ${ }^{447}$

Following WWII, the established economic circumstances in Belgium reversed. Flanders developed a modern economy and emerged as one of the wealthiest regions in Europe, while Wallonia, faced with decreased mining productivity and the closure of factories, suffered a sharp postindustrial decline. Wallonia became dependent on subsidies from the national government, which the newly prosperous Flemish people often viewed as being unfairly paid out of their taxes. ${ }^{448}$ Financial transfers from Flanders to Wallonia remain a critical source of Flemish nationalist grievance today. ${ }^{449}$

The economic rise of Flanders was accompanied by sweeping changes to the Belgian political system. Beginning in 1970, a series of constitutional reforms reflecting the territorial-linguistic divide transformed Belgium from a highly centralised unitary State into a highly decentralised federal State. The constitutional reforms established three regions -Flanders, Wallonia, and Brussels-Capital- and three "language communities" -Dutch, French, and German-, each with their own parliaments and areas of competency. Flanders and Wallonia are officially monolingual, while Brussels-Capital is officially bilingual. Only those residual powers not

447 Robert Mnookin and Alain Verbeke, "Persistent Nonviolent Conflict with No Reconciliation: The Flemish and Walloons in Belgium", Law and Contemporary Problems, Vol. 72, No. 2, 2009, p. 159.

448 Robert Mnookin and Alain Verbeke, "Persistent Nonviolent Conflict with No Reconciliation: The Flemish and Walloons in Belgium", Law and Contemporary Problems, Vol. 72, No. 2, 2009, p. 161.

449 Robert Mnookin and Alain Verbeke, "Persistent Nonviolent Conflict with No Reconciliation: The Flemish and Walloons in Belgium", Law and Contemporary Problems, Vol. 72, No. 2, 2009, p. 172. 
explicitly reserved for the regions or language communities belong to the federal government. ${ }^{450}$ To a far greater extent than either Spain or the United Kingdom, Belgium "exhibits the hallmarks of an ethnic conflict".451 The Flemish and Walloons speak different languages, live in different areas, attend different schools, consume different media, and are largely governed by different institutions. Indeed, they may no longer even be able to vote for the same political parties. ${ }^{452}$

Flemish nationalism was initially represented in politics by the Volksunie, which was later split up into several new parties, i.e., the Vlaams Blok, Spirit and the Nieuw-Vlaamse Alliantie. ${ }^{453}$ The Vlaams Blok, which explicitly advocated Flemish independence, ${ }^{454}$ gained increasing electoral support during the 1990s and early 2000s. In 2010, after the conviction of the Vlaams Blok for incitement to discriminate and racism, the party was dissolved which subsequently led to its reorganisation as the Vlaams Belang. The Nieuw-Vlaamse Alliantie then became the largest political party in Flanders and in Belgium. The unexpected success of the NieuwVlaamse Alliantie led to the achievement of a new record: the longest period without a functioning national government. ${ }^{455}$ Some scholars compared this situation to a forced marriage:

"Belgians are condemned to stick together [...]. They cannot divorce. They can make hell out of each other life in this forced marriage. Or they can try to make the best out of it, probably by enhancing their living apart together relationship". ${ }^{456}$

In the 2014 federal elections, the Nieuw-Vlaamse Alliantie increased their dominant position and also became the largest party in both the Flemish

450 Kris Deschouwer, The Politics of Belgium: Governing a Divided Society. Basingstoke, Palgrave Macmillan, 2009, p. 56.

451 Michael Keating, "European Integration and the Nationalities", Question Politics \& Society, vol. 32 no. 3, September, 2004, p. 365.

452 Between 1968 and 1978, the three major parties (the Christian Democrats, Socialists, and Liberals) split into French- and Dutch-speaking factions, which only contest elections within their respective territorial and linguistic spheres.

453 Michael Keating, "European Integration and the Nationalities", Question Politics \& Society, vol. 32 no. 3, September, 2004, p. 370.

454 Bruno Vandecasteele, Ferdi Deville \& Hendrik Vos, "Belgium, separatism, and the EU”, Fair Observer, 2012, n. page., available at http://www.fairobserver.com/ region/europe/belgium-separatism-and-eu.

455 Christopher K. Connolly, "Independence in Europe: Secession, Sovereignty, and the European Union", Duke Journal of Comparative \& International Law, Vol. 24, 2013, p. 66.

456 Lieven De Winter, "Belgium: from federalism to confederalism or to a big bang in 2014?", Cuadernos Manuel Giménez Abad, No. 4, December 2012, p. 29. 
Parliament and in the Belgian delegation to the European Parliament, after the regional and European elections of 2014. Although the Nieuw-Vlaamse Alliantie has been considered more conservative in ascertaining Flemish independence, paragraph 3 of its political manifesto is very clear on this point, as it states that the party must strive for an independent Flanders: "Only by achieving autonomy — such as the peoples of Sweden, Ireland, Portugal and Greece-can Flanders truly develop itself within the European Union. That means that we have to strive for an independent Flanders". ${ }^{457}$

Table No. 2

\begin{tabular}{|l|l|}
\hline \multicolumn{2}{|c|}{ Milestones of the Flemish independence process } \\
\hline 1830 & Independence of Belgium \\
\hline $\begin{array}{l}\text { Late } 19^{\text {th }} \text { century - } \\
\text { early } 20^{\text {th }} \text { century }\end{array}$ & Flemish Movement (Vlaamse Beweging) \\
\hline 1954 & Establishment of Volksunie \\
\hline 1970 & $\begin{array}{l}\text { Decentralisation of Belgium (establishment of the regions, } \\
\text { language communities, and regional parliaments) }\end{array}$ \\
\hline 1978 & Vlaams Blokseparated from Volksunie \\
\hline 2001 & Establishment of Spirit and the Nieuw-Vlaamse Alliantie \\
\hline 2004 & Establishment of Vlaams Belang \\
\hline 2010 & $\begin{array}{l}\text { Belgian federal elections. 541 days without government. } \\
\text { The Nieuw-Vlaamse Alliantie became the largest party in the } \\
\text { Belgian Parliament. }\end{array}$ \\
\hline 2014 & $\begin{array}{l}\text { Belgian federal elections. The Nieuw-Vlaamse Alliantie } \\
\text { strengthened its position as the largest party in the Belgian } \\
\text { Parliament. }\end{array}$ \\
\hline
\end{tabular}

457 Translation by the author. The original text reads as follows: "Alleen door een autonomie te verwerven -zoals die van volkeren als de Zweden, de Ieren, de Portugezen of de Grieken - kan Vlaanderen zich binnen de Europese Unie echt ontplooien. Dat betekent dat we moeten streven naar een onafhankelijk Vlaanderen". 


\section{Scotland}

Scotland's existence as an independent kingdom ended in 1707, when the Scottish parliament entered into the Treaty of Union with England. ${ }^{458}$ In $1603,{ }^{459}$ the crowns of Scotland and England were united under King James VI of Scotland, who became King James I of England by inheritance. ${ }^{460}$ However, the Union of Crowns in 1603 did not entail a real union, since Scotland and England kept their own self-ruling institutions, their own legal systems, and trade and social barriers between Scotland and England remained. The Treaty of Union dissolved the Scottish parliament and transferred political authority to Westminster; the Westminster Parliament was increased by 45 commoners and 16 peers who represented Scotland. According to Article 1, the Two Kingdoms of Scotland and England "shall upon the 1st May next ensuing the date hereof, and forever after, be United into One Kingdom by the Name of Great Britain". By doing this, two previously independent kingdoms were merged to create one new kingdom. However, Scotland retained its own legal ${ }^{461}$ and educational systems ${ }^{462}$ and Presbyterian Church. ${ }^{463}$ Almost one hundred years later, in 1800, the Act of Union with Ireland ${ }^{464}$ led to the creation of the United Kingdom of Great Britain and Ireland, which later became the United Kingdom of Great Britain and Northern Ireland following the

458 The Acts of Union were two Acts of Parliament: the Union with Scotland Act 1706 passed by the Parliament of England, and the Union with England Act passed in 1707 by the Parliament of Scotland. The Treaty of Union was negotiated by commissioners on behalf of the English and Scottish Parliaments and incorporated into the Acts of Union. The English Act incorporated the terms of the Scottish Act with the additional provisions regarding the Church of England. See Union with Scotland Act 1706 available at http://www.legislation.gov.uk/aep/ Ann/6/11\#commentary-c1253315 and Union with England Act 1707 available at http://www.legislation.gov.uk/aosp/1707/7.

45925 July 1603 (coronation).

460 Elizabeth I died without issue on 24 March 1603.

461 Section 19 of the Union with England Act 1707: "That the Court of Session or Colledge of Justice do after the Union and notwithstanding thereof remain in all time coming within Scotland as it is now constituted by the Laws of that Kingdom and with the same Authority and Priviledges as before the Union subject nevertherless to such Regulations for the better Administration of Justice as shall be made by the Parliament of Great Britain. And that all other Courts now in being within the Kingdom of Scotland do remain but subject to Alterations by the Parliament of Great Britain".

462 Section 25 of the Union with England Act 1707: "That the Universities and Colledges of Saint Andrews Glasgow Aberdeen and Edinburgh as now Established by Law shall Continue within this Kingdom for ever".

463 Section 25 of the Union with England Act 1707: "the (...) Presbyterian Government shall be the only Government of the Church within the Kingdom of Scotland".

${ }^{464}$ Union with Ireland Act 1800 available at http://www.legislation.gov.uk/apgb/ Geo3/39-40/67. 
independence of the Irish Free State in $1922 .^{465}$

The first Scottish nationalist political party was the National Party of Scotland. The National Party of Scotland was founded in 1928, and was the first Scottish political party to campaign for Scottish self-determination. ${ }^{466}$ According to Harvie, it mobilised traditional nationalists from Catholic intellectuals, students, journalists, to disillusioned members of the Independent Labour Party, including its first Chairman and Secretary, Roland Muirhead and John MacCormick. ${ }^{467}$ In 1932, another Scottish nationalist political party was founded: the Scottish Party. It was essentially formed by a group of members of the Unionist Party. ${ }^{468}$ In 1934, the SNP was established as result of a merger between the Scottish Party and the National Party of Scotland.

The position of the SNP regarding the independence of Scotland has changed, similar to that of a pendulum movement, from the devolutionist stance of the Scottish Party (which supported the establishment of a devolved Scottish Assembly within the United Kingdom) to the full independence for Scotland stance of the National Party of Scotland. Scottish nationalism was relatively dormant until the $1960 \mathrm{~s} .{ }^{469}$ However, there are certain events which are worth mentioning. In 1949 more than two million Scots had signed the Scottish Covenant, which unsuccessfully called for home rule in Scotland. On Christmas Day 1950, Scottish nationalists stole the Stone of Scone,${ }^{470}$ the ancient stone upon which Scottish kings had traditionally been crowned, from Westminster Abbey. Despite these symbolic conquests, the first milestone for Scottish nationalism was the election of Winnie Ewing, who won the SNP's first parliamentary seat in Westminster in 1967, with her slogan "Stop the world, Scotland wants to get on".

Scottish nationalism's greatest success came in the general election of October 1974, coinciding with the boom of North Sea oil. The production

465 On the negotiation of the Articles of Agreement for a Treaty Between Great Britain and Ireland, see Matthew Heintz, "The Freedom to Achieve Freedom: Negotiating the Anglo-Irish Treaty", Intersections 10, no. 1 (2009), pp. 431-451.

466 Christopher Harvie, Scotland and Nationalism. Scottish society and politics 1707 to the present, Routledge, London-New York, 2004 (4th edition), p. 20.

${ }^{467}$ Christopher Harvie, Scotland and Nationalism. Scottish society and politics 1707 to the present, Routledge, London-New York, 2004 (4th edition), p. 21.

${ }^{468}$ Christopher Harvie, Scotland and Nationalism. Scottish society and politics 1707 to the present, Routledge, London-New York, 2004 (4th edition), p. 22.

469 In its first elections, the 1935 General Election, the SNP contested eight seats and won none.

470 The Stone of Scone, also called Stone of Destiny, was later recovered and restored to the Westminster Abbey. In 1996 the British Government returned the stone to Scotland. 
of North Sea oil in Scottish waters, which raised the possibility of Scottish economic autonomy, also increased the support for an independent Scotland. The political campaigning was marked by the slogan "It's Scotland's oill". The SNP won more than $30 \%$ of the Scottish vote and won 11 of the 71 Scottish seats that were available in the British Parliament.

The Labour Party, that won the October 1974 election by a majority of only three seats, announced plans for the devolution of political authority to Scottish institutions. Its proposal was reflected in the Scotland Act 1978, which was designed to grant Scotland its own assembly with limited legislative and executive powers and a referendum on Scottish devolution was held. Although this proposal was favoured by a majority $(52.9 \%)$ of the Scots who voted, the referendum did not achieve the $40 \%$ of the overall electorate threshold required for the result to stand. ${ }^{471}$ The SNP then withdrew its support from the Labour government, causing it to lose a vote of confidence and forcing the May 1979 general election, which was ultimately won by the Conservatives led by Margaret Thatcher. The SNP subsequently lost 9 of its 11 seats in Parliament.

During the period of successive Conservative led governments, the issue of devolution was shelved during the 1980s and early 1990s. A year after the Labour Party returned to power under Tony Blair, the Labour government introduced the Scotland Act 1998, which provided for the creation of a Scottish Parliament
"and for the establishment of a Scottish Parliament and Administration and other changes in the government of Scotland; to provide for changes in the constitution and functions of certain public authorities; to provide for the variation of the basic rate of income tax in relation to income of Scottish taxpayers in accordance with a resolution of the Scottish Parliament; to amend the law about parliamentary constituencies in Scotland; and for connected purposes". ${ }^{472}$

In contrast to the failed devolution referendum of 1979, Scottish voters enthusiastically backed the Scotland Act $1998,{ }^{473}$ and in 1999 the first Scottish Parliament since 1707 met in Edinburgh.

471 The result of the referendum in Scotland was a narrow majority in favour of devolution ( $52 \%$ to $48 \%$ ), but a condition of the referendum was that $40 \%$ of the total electorate had to vote in favour in order to make it valid. But the turnout was only $63.6 \%$, so only $32.9 \%$ of the electorate voted "Yes". The Scotland Act 1978 was consequently repealed in March 1979 by a vote of 301-206 in Parliament.

472 Scotland Act, 1998, c. 46.

$4731,775,045$ (74.3\%) voted in favour of a Scottish Parliament, with 614,400 (25.7\%) against; and 1,512,889 (63.5\%) supported giving the Parliament tax-varying powers, with $870,263(36.5 \%)$ against. 
At the first elections to the Scottish Parliament in May 1999, Labour won 56 seats, the SNP 35, the Conservatives 18, and the Liberal Democrats 17, while the Greens and the Scottish Socialists each won one seat (an independent candidate won the remaining seat).

In May 2003, the Scottish Parliament's second elections took place. The results showed that support for Labour and the SNP dropped (they won 50 and 27 seats, respectively), while the Liberal Democrats and the Conservatives performed at roughly the same level as in 1999. Notably, minor parties increased their seats in the Scottish Parliament significantly, with the Greens winning 7 seats, the Scottish Socialists 6, and independents 4.

The 2007 Scottish Parliament elections saw a breakthrough for the SNP, as it emerged as the largest party in terms of both the popular vote and number of seats won. With only one seat more than the Labour party (47 vs. 46), the SNP went on to form a minority administration and Alex Salmond was sworn in as First Minister of Scotland. The SNP's decisive May 2011 victory pushed independence to the forefront of Scotland's political agenda. The SNP won an overall majority in the Scottish Parliament with 69 seats. With a majority government, the SNP were able to legislate for an independence referendum. On 25 January 2012, Alex Salmond announced plans to hold a referendum on Scottish independence in the autumn of 2014. Initially, the British Government led by Prime Minister David Cameron opposed Scottish independence. Notwithstanding the Prime Minister's opposition, the Edinburgh Agreement was concluded on 15 October 2012, ${ }^{474}$ whereby the British Government granted the Scottish parliament authority to hold a referendum, and the two governments agreed to the ground rules for the referendum process. ${ }^{475}$

The franchise for the referendum was defined by the Scottish Independence Referendum (Franchise) Act 2013. ${ }^{476}$ Eligibility to vote mirrored the franchise at Scottish parliament and local government elections, which comprised citizens of the UK, the Commonwealth, the Republic of Ireland and other EU Member States who were registered in Scotland.

On 18 September 2014, the Scottish independence referendum was held. The proposition "Should Scotland be an independent country?" was rejected

${ }^{474}$ Agreement between the United Kingdom Government and the Scottish Governement on a referendum on independence of Scotland, Edinburgh, 15 October 2012.

475 See on the background of the Scottish referendum Stephen Tierney, "Legal Issues Surrounding the Referendum on Independence for Scotland", European Constitutional Law Review, 2013, pp. 359-390.

476 Scottish Independence Referendum (Franchise) Act 2013, passed by the Parliament on 27 June 2013 and received Royal Assent on 7 August 2013. 
by a margin of 10.6 percentage points: 2,001,926 electors (55.3\%) voted "No" and 1,617,989 electors (44.7\%) voted "Yes". There was a majority for "No" in 28 of Scotland's 32 local authority areas, including the capital, Edinburgh. There was a majority for "'Yes" in Scotland's largest city, Glasgow. The turnout at the referendum was $84.6 \%$ including rejected papers (84.5\% based on valid votes). Following the result of the independence referendum, Alex Salmond resigned as Scottish First Minister and party leader, and was subsequently replaced by Nicola Sturgeon.

The issue of whether Scotland should be an independent country has not been fully settled by the 2014 referendum. The debate on the independence of Scotland has been reignited since the referendum on whether the United Kingdom should leave the EU was announced. Before the British general election of May 2015, Prime Minister David Cameron declared his commitment to hold a referendum on Britain's membership of the EU by the end of 2017 if the Conservatives won that general election. ${ }^{477}$ On 27 May 2015, the referendum was formally announced in the policy speech read by Queen Elizabeth II during the official State Opening of the British Parliament. ${ }^{478}$ On 2 June 2015, in a speech addressing the European Policy Centre, the First Minister of Scotland, Nicola Sturgeon, stated that the referendum on the United Kingdom membership of the EU

"could be one scenario producing the kind of material change in circumstances which would precipitate popular demand for a second independence referendum. Bluntly, I believe the groundswell of anger among ordinary people in Scotland in these circumstances could produce a clamour for another independence referendum which may well be unstoppable". 479

477 According to the 2015 Conservative Party General Election Manifesto "It will be a fundamental principle of a future Conservative Government that membership of the European Union depends on the consent of the British people-and in recent years that consent has worn wafer-thin. That's why, after the election, we will negotiate a new settlement for Britain in Europe, and then ask the British people whether they want to stay in the EU on this reformed basis or leave (...) We will hold that in-out referendum before the end of 2017 and respect the outcome". Conservative Party, Strong Leadership, a clear economic plan, a brighter, more secure future: The Conservative Party manifesto 2015, p. 72.

478 "My Government will renegotiate the United Kingdom's relationship with the European Union and pursue reform of the European Union for the benefit of all Member States. Alongside this, early legislation will be introduced to provide for an in/out referendum on membership of the European Union before the end of 2017". HL Deb, 27 May 2015, col 6.

479 First Minister of Scotland, Nicola Ferguson Sturgeon, speech addressing the European Policy Centre, Brussels, 2 June 2015, available at http://news. scotland.gov.uk/Speeches-Briefings/First-Minister-speech-to-European-Policy- 
On 28 May 2015, the European Union Referendum Bill was introduced to the House of Commons and the European Union Referendum Act 2015 was passed on 17 December 2015. ${ }^{480}$

The "Brexit" referendum took place on 23 June 2016, resulting in a majority to leave the EU by $51.9 \%$ to $48.1 \%$. Remarkable is the fact that Scotland voted decisively in favour of remaining in the EU: all voting areas in Scotland voted to remain in the EU (leave 38\%, remain 62\%). The reaction of Scottish Government was immediate. The First Minister of Scotland made the following remarks on a second independence referendum:

"The manifesto that the SNP was elected on last month said this:

'The Scottish Parliament should have the right to hold another referendum...if there is a significant and material change in the circumstances that prevailed in 2014, such as Scotland being taken out the EU against our will'.

Scotland does now face that prospect - it is a significant and material change in circumstances - and it is therefore a statement of the obvious that the option of a second referendum must be on the table. And it is on the table.

Clearly, though, there are a lot of discussions to be had before final decisions are taken.

It would not be right to rush to judgement ahead of discussions on how Scotland's result will be responded to by the EU.

However, when the Article 50 process is triggered in three months' time, the UK will be on a two year path to the EU exit door.

If Parliament judges that a second referendum is the best or only way to protect our place in Europe, it must have the option to hold one within that timescale.

Centre-1977.aspx. Compare: Sébastien Platon, "Brexit/Scot-in: Could a NonIndependent Scotland Stay in the European Union in Case of a Brexit?", available at http://verfassungsblog.de, 10 May 2015.

480 A Bill To make provision for the holding of a referendum in the United Kingdom and Gibraltar on whether the United Kingdom should remain a member of the European Union, available at http://www.legislation.gov.uk/ukpga/2015/36/pdfs/ ukpga 20150036 en.pdf. On the negotiations on the status quo of the United Kingdom and the so-called 'Cameron's agreement' with the EU prior to the referendum, see: Michael Emerson (ed), Britain's Future in Europe: The Known Plan A to Remain or the Unknown Plan B to Leave, CEPS, Rowman \& Littlefield, London, 2016. 
That means we must act now to protect that position. I can therefore confirm today that in order to protect thatposition we will begin to prepare the legislation that would be required to enable a new independence referendum to take place if and when Parliament so decides". ${ }^{481}$

The result of the United Kingdom European's Union membership referendum poses numerous issues directly linked to the topic of this book. Although the withdrawal of an EU Member State is a situation foreseen in the EU law, the same questions related to the possession of the status of citizen of the Union arise in the "Brexit" scenario.

It is clear that the possession of the nationality of an EU Member Stat is the conditio sine qua non for the enjoyment of the latter status. Thus, from the outset, if the United Kingdom withdraws its membership from the EU, British citizens would no longer be citizens of the Union. ${ }^{482}$ As EU citizenship is the fundamental status of nationals of the Member States, it is necessary to explain how the withdrawal process could affect that status and the rights flowing therefrom, and to assess the role that EU law can play in this scenario. The following questions therefore need to be answered:

- Would British citizens no longer qualify as citizens of the Union?

- What would be the legal situation of EU citizens from other Member States residing in the United Kingdom after the withdrawal of EU membership?

- What would be the status of British citizens residing in other EU Member States?

- What about the situation of third country nationals residing in the United Kingdom?

It is remarkable that during the Scottish referendum campaign the question of EU citizenship status of potential Scottish nationals was almost taken for granted. However, after the United Kingdom referendum on membership of the $\mathrm{EU}$, one of the issues which has raised concern is the situation of EU Citizens who are resident in Scotland. ${ }^{483}$ Even Theresa May,

481 Public statement of the Scottish First Minister, Nicola Sturgeon, made on 24 June 2016, available at http://news.scotland.gov.uk/Speeches-Briefings/First-MinisterEU-Referendum-result-25ae.aspx\#downloads.

482 Elspeth Guild, BREXIT and its Consequences for UK and EU Citizenship or Monstrous Citizenship, Brill Nijhoff, Leiden-Boston, 2017, p. 33.

483 See the letter of the First Minister of Scotland addressed to "European Union citizens living in Scotland" in which she stated that "The immediate status of EU nationals living in Scotland has not changed and you retain all the same rights to 
in her speech laying out the United Kingdom plan for "Brexit", 484 expressly stressed that the situation of British citizens living in the EU and European citizens living in the United Kingdom needs to be addressed in the "Brexit" negotiations. She stated that

"We want to guarantee the rights of EU citizens who are already living in Britain, and the rights of British nationals in other member states, as early as we can.

I have told other EU leaders that we could give people the certainty they want straight away, and reach such a deal now. Many of them favour such an agreement - 1 or 2 others do not - but I want everyone to know that it remains an important priority for Britain - and for many other member states - to resolve this challenge as soon as possible. Because it is the right and fair thing to do". ${ }^{85}$

This issue has been also included in the white paper "The United Kingdom's exit from and new partnership with the European Union", recently released by the British Government. ${ }^{486}$

In the context of the "Brexit", the position of the Scottish Government is well-defined:

"there is clearly a strong desire in Scotland to be a full and active member of the European family of nations. The Scottish Government shares that desire. (...) One option -in my view, the best option- is to become a full member of the EU as an independent country". ${ }^{487}$

live and to work here. I believe those rights for the longer term should be guaranteed immediately and have written to the Prime Minister and all of the candidates to succeed him, calling for all EU citizens living here to be given an assurance that their residency will be unaffected". Letter available at http://scottishgovernment. presscentre.com/News/Protection-for-EU-citizens-rights-25e3.aspx.

484 See British Prime Minister, Theresa May, speech on "The government's negotiating objectives for exiting the EU", delivered on 17 January 2017, available at https:// www.gov.uk/government/speeches/the-governments-negotiating-objectives-forexiting-the-eu-pm-speech.

485 Point six, British Prime Minister speech on "The government's negotiating objectives for exiting the EU", delivered on 17 January 2017, available at https:// www.gov.uk/government/speeches/the-governments-negotiating-objectives-forexiting-the-eu-pm-speech.

486 The United Kingdom's exit from and new partnership with the European Union, United Kingdom Government, February 2017, available at https://www.gov. uk/government/uploads/system/uploads/attachment data/file/589191/The United Kingdoms exit from and partnership with the EU Web.pdf.

487 Scotland's Place in Europe, Scottish Government, December 2016, foreword by the 
In this line, the Scottish Government has also published a new draft referendum bill for public consultation. ${ }^{488}$ This draft invited "views on the proposals for how the referendum would be run" 489 with the aim of protecting "Scotland's interests in the wake of the EU referendum". ${ }^{490}$ This proposal was subject to public consultation from October 2016 until January 2017.

Furthermore, on Monday 13 March 2017 the Scottish First Minister announced that the Scottish Government was planing a referendum on independence to be held between the Autumn of 2018 and the Spring of 2019. ${ }^{491}$ In her speech, she stated that

"I will take the steps necessary now to make sure that Scotland will have a choice at the end of this process - a choice of whether to follow the UK to a hard Brexit, or to become an independent country able to secure a real partnership of equals with the rest of the UK and our own relationship with Europe". ${ }^{992}$

This speech was delivered on the eve of Article 50 TEU being triggered. After the British Parliament gave its approval, ${ }^{493}$ the European Union (Notification of Withdrawal) Act $2017^{494}$ was passed by Parliament on 13 March and it became an Act of Parliament on 16 March. On 29 March 2017, the British Prime Minister notified to the European Council the United

First Minister of Scotland, Nicola Sturgeon. For a detailed analysis of this White Paper, see Michael Emerson, "Scotland knows what it wants with the EU, while London seems still not to know", CEPS, 24 December 2016, available at https:// www.ceps.eu/publications/scotland-knows-what-it-wants-eu-while-londonseems-still-not-know.

488 Consultation on a Draft Referendum Bill, Scottish Government, October 2016.

489 Consultation on a Draft Referendum Bill, Scottish Government, October 2016, p. 3.

490 Consultation on a Draft Referendum Bill, Scottish Government, October 2016, p. 3.

491 See Scottish First Minister, Nicola Sturgeon, speech delivered on 13 March 2017, available at https://news.gov.scot/speeches-and-briefings/first-minister-speech-1.

492 See Scottish First Minister, Nicola Sturgeon, speech delivered on 13 March 2017, available at https://news.gov.scot/speeches-and-briefings/first-ministerspeech-1.

${ }^{493} \mathrm{R}$ (Miller) -v- Secretary of State for Exiting the European Union, Case No. CO/3809/2016 and CO/3281/2016, 3 November 2016. This decision from the High Court was confirmed by the Supreme Court on 24 January 2017 [R (on the application of Miller and another) (Respondents) $v$ Secretary of State for Exiting the European Union (Appellant), reference by the Attorney General for Northern Ireland - In the matter of an application by Agnew and others for Judicial Review reference by the Court of Appeal (Northern Ireland) - In the matter of an application by Raymond McCord for Judicial Review, UKSC 2016/0196, 24 January 2017].

494 European Union (Notification of Withdrawal) Act 2017, 16 March 2017, available at http://www.legislation.gov.uk/ukpga/2017/9/pdfs/ukpga 20170009 en.pdf. 
Kingdom's intention to withdraw from the EU. ${ }^{495}$ Now, we will have to wait and see the results of the negotiations between the United Kingdom and the EU and the role that Scotland can play in that framework.

Table No. 3

\begin{tabular}{|l|l|}
\hline \multicolumn{2}{|c|}{ Milestones of the Scottish independence process } \\
\hline 1707 & Act of Union \\
\hline 1934 & Establishment of the Scottish National Party (SNP) \\
\hline October 1974 & UK General elections \\
\hline 1978 & Scotland Act 1978 (first attempt of devolution) \\
\hline 1998 & Scotland Act 1998 (passed) \\
\hline 1999 & First elections to the Scottish Parliament \\
\hline 2007 & $\begin{array}{l}\text { First elections won by the SNP (minority government). Alex } \\
\text { Salmond elected First Minister of Scotland }\end{array}$ \\
\hline 2011 & $\begin{array}{l}\text { SNP win majority of seats in Scottish Parliament with commitment } \\
\text { to seek independence by holding a referendum }\end{array}$ \\
\hline January 2012 & $\begin{array}{l}\text { Alex Salmond announced plans to hold a referendum on Scottish } \\
\text { independence in the autumn of 2014 }\end{array}$ \\
\hline 15 October 2012 & $\begin{array}{l}\text { Edinburgh Agreement signed by Scottish and the United Kingdom } \\
\text { governments }\end{array}$ \\
\hline $\begin{array}{l}\text { 18 September } \\
2014\end{array}$ & $\begin{array}{l}\text { Referendum vote in Scotland } \\
\text { Result: 55.3\% voted 'No', 44.7\% voted 'Yes' }\end{array}$ \\
\hline 23 June 2016 & $\begin{array}{l}\text { United Kingdom European Union membership referendum } \\
\text { (“Brexit") } \\
\text { Result: 51.9\% voted to leave, 48.1\% voted to stay. Every single } \\
\text { voting area in Scotland voted to remain in the EU. }\end{array}$ \\
\hline Consultation on a Draft Referendum Bill \\
\hline 13 March 2017 & $\begin{array}{l}\text { Scottish First Minister announced a referendum on independence } \\
\text { to be held between the Autumn of 2018 and the Spring of 2019 }\end{array}$ \\
\hline Article 50 was triggered \\
\hline March 2017 2016
\end{tabular}

495 See British Prime Minister, Theresa May, letter to Donald Tusk triggering Article 50, available at https://www.gov.uk/government/uploads/system/uploads/ attachment data/file/604079/Prime Ministers letter to European Council President Donald Tusk.pdf? ga=1.124757325.634667512.1486133147 and the statement by the European Council (Article 50) on the United Kingdom notification, available at http://www.consilium.europa.eu/press-releasespdf/2017/3/47244656886 en.pdf. 


\section{Referenda, Consultation, Electoral rights and First Determination of nationals (Catalan, Flemish and Scottish proposals)}

As previously noted, international law recognises, on the one hand, the prerogative of States to determine who their citizens are and, on the other hand, the right of individuals to possess a nationality. ${ }^{496}$ Defining who the nationals of a given State are is essential to meeting the requirements of Statehood under the Montevideo Convention. ${ }^{497}$ Thus, the determination of State citizenship ab initio is unavoidable. Given the aim of the regions which are the subject of this research to become independent States and since it may be expected that the hypothetical new States would adopt nonarbitrary criteria for its $a b$ initio nationality, it would be reasonable that these criteria are published at the very least at the time of the referendum, and serve as the basis for its franchise. ${ }^{498}$

In this section an analysis of the Catalan, Flemish and Scottish proposals dealing with the first determination of their nationals upon independence is conducted, paying special attention to the criteria adopted by Catalonia and Scotland regarding the eligibility to vote in their independence queries. In this sense, it is necessary to establish a clear distinction between two questions: 1) who votes in the referendum/consultation that might lead to the creation of a new State where a new nationality is to be defined and 2) who would qualify as a Catalan, Flemish or Scottish national from the moment of independence and, therefore, would participate as a national in the subsequent elections in an independent Catalan, Flemish or Scottish State. In answering these two questions, special consideration is given to the following categories of individuals:

496 See Chapter 1, Section 3.1.

${ }^{497}$ See Chapters 2, Section 1.1.

498 Ruvi Ziegler, "Independence Referendums: Who should vote and who should be offered citizenship?", Kick-off contribution, European University Institute, Robert Schuman Centre for Advanced Studies, Florence, 2014. 
1. Nationals of the predecessor State (Belgium, Spain and the United Kingdom)
a. living in the territory of the successor State,
b. residing abroad (in other Member State), or
c. residing the territory of the predecessor State but with a certain connection or link with the successor State;

2. Nationals of other EU Member States living in the territory of the successor State;

3. Third country nationals living in the territory of the successor State.

\subsection{Catalonia}

\subsubsection{Eligibility to Vote in the Independence Query}

According to Article 4 of the Decree calling the consultation on independence for Catalonia, ${ }^{499}$ besides regional electors (persons over 16 years who have the political status of a Catalan), ${ }^{500}$ citizens of other EU Member States above the age of 16 residing in Catalonia for more than one year and registered therein were eligible to vote. ${ }^{501}$ Similarly, the Decree enfranchised third country nationals over the age of 16, registered in Catalonia's Population Registry and having legal residence for an uninterrupted period of three years immediately preceding the announcement of the consultation. Catalans living and residing abroad could vote in the consultation if they were voluntarily registered in the so-called Registry of Catalans living

499 Decree 129/2014, de 27 de setembre, de convocatòria de la consulta popular no referendària sobre el futur polític de Catalunya, Catalan government Official Gazette (Diari Oficial de la Generalitat de Catalunya), No. 6715A, 27 September 2014, pp. 1-23.

500 Article 7(1) of the Catalan Statute of Autonomy states that all Catalan or Spanish citizens legally resident in Catalonia enjoy the political status of citizens of Catalonia. See the Organic Law 6/2006, 19 July, amending the Catalan Statute of Autonomy, Boletín Oficial del Estado No. 172, 20 July 2006, pp. 27269-27310.

501 See on this issue Guayasén Marrero González, "The role of migrants in the Catalan independence process: a legal analysis", Pro-independence Movements and Immigration: Discourse, Policy and Practice, Roberta Medda-Windischer and Patricia Popelier (eds.), 2016, pp. 161-207. Notice that the analysis made of voting rights in this context has been already published in this contribution to Proindependence Movements and Immigration: Discourse, Policy and Practice. 
abroad. ${ }^{502}$ Furthermore, all non-Spanish nationals who met the residence requirement to vote had to express their willingness to participate in the referendum before the Registre de participació en consultes populars no referendàries. ${ }^{503}$ Catalans living in other Spanish autonomous communities and registered in those communities were not able to vote. Drawing a distinction between Catalans living and reside in the rest of Spain may be questionable. However, the rationale behind this decision was given no attention in the explanatory memorandum of the Decree.

After the Constitutional Court suspended the Decree calling the consultation on independence and the law upon which it was based, the requirements that non-Spanish nationals were required to meet in order to cast their vote were changed. The alternative vote (the so-called "participatory process") announced by the Catalan Government aimed to be more of a survey without legal implications, with no official electorate census or legal basis, in which only the questions remained the same: 'Do you want Catalonia to be a State?" If the answer is yes, "Do you want that State to be independent?". ${ }^{54}$ The intervention of the Constitutional Court not only considerably changed the nature of the original consultation -which was transformed into a "participatory process" with no legal basis that could be challenged before that Court, but also entailed an easing of the requirements for voting amongst non-Spanish citizens residing in Catalonia. Thus, all non-Spanish citizens who were at least 16 years of age on 9 November 2014 and could prove their residence in Catalonia were eligible to vote in the "participatory process" on the independence of Catalonia.

502 The Registre de catalans i catalanes residents a l'exterior was established by the Decree 71/2014, 27 May, creating the Registry of Catalans living abroad and establishing the requirements and procedures for registration, Catalan Government Official Gazette (Diari Oficial de la Generalitat de Catalunya), No. 6635, 2 June 2014, pp. 1-8. The Registry is managed by the Department of Foreign Affairs and the European Union of the Government of Catalonia. Registration is voluntary and is aimed at people who have the political status of Catalan as defined in Article 7(1) of the Catalan Statute of Autonomy. In theory, the registry aims to meet the demands and needs of the Catalans living abroad to develop lines of action by the Government, in addition to facilitating the rights of Catalans living abroad.

${ }_{503}$ Article 4, para. 5, Decret 129/2014, de 27 de setembre, de convocatòria de la consulta popular no referendària sobre el futur polític de Catalunya.

504 The new design was clearly intended to avoid another appeal by the Spanish Government before the Constitutional Court. Notwithstanding, five days before the 9 November 2014, the Constitutional Court voted unanimously to accept an appeal filed by the State Attorney and suspended the participatory process on selfrule and the preparative acts or any others linked to the independence query. The Catalan reaction followed swiftly thereafter: it would maintain the alternative vote despite the Court's suspension, and it did so. 


\subsubsection{Eligibility for Catalan Nationality ab initio in a Potential New Catalan State}

Throughout the Catalan independence process, questions related to citizenship status and citizenship rights received relatively little attention. ${ }^{505}$ The Advisory Council for the National Transition ${ }^{506}$ only briefly touched upon this topic in report No. 10 regarding the constitutional process. ${ }^{507}$ This report advises the adoption of interim legislation on nationality with the purpose of determining who may participate with full voting rights in the constitutional process, i.e. the initial determination of Catalan nationals if Catalonia achieves independence. The report focuses on the need to draft legislation for the transitional period - between the referendum and the effective independence of Catalonia- in order to determine the scope of Catalan nationals at the time of the eventual independence.

In contrast to the Scottish proposal, ${ }^{508}$ there is no specific recommendation regarding the acquisition of the Catalan nationality by foreign citizens residing in Catalonia. The initial Catalan nationality in a hypothetical independent Catalan State would be limited only to those who currently enjoy the political status of Catalans according to Article 7(1) of the Catalan Statute of Autonomy, that is, Spanish citizens who are residents in a municipality of Catalonia. Additionally, the initial Catalan citizenship would be offered to two other categories of Spanish citizens: Spanish

505 See on this issue Guayasén Marrero González, "The role of migrants in the Catalan independence process: a legal analysis", Pro-independence Movements and Immigration: Discourse, Policy and Practice, Roberta Medda-Windischer and Patricia Popelier (eds.), 2016, pp. 161-207. Notice that the analysis made of the initial determination of Catalan nationals has been already published in this contribution to Pro-independence Movements and Immigration: Discourse, Policy and Practice.

506 The Advisory Council for the National Transition (Consell Assessor per a la Transició Nacional) is a body created by the government of Catalonia to advise the government on the national transition of Catalonia and achieving Catalan selfdetermination referendum, according to the Decree 113/2013 [Decret 113/2013, de 12 de febrer, de creació del Consell Assessor per a la Transició Nacional, Catalan Government Official Gazette (Diari Oficial de la Generalitat de Catalunya), No. 6315, 14 February 2013, pp. 8187-8188]. The Advisory Council for the National Transition is composed of 14 members, elected by the Catalan government on the basis of their recognised standing and their contribution to the final task of achieving the Catalan self-determination referendum. Its president is Carles Viver i Pi-Sunyer, former judge of the Spanish Constitutional Court and Professor of Law at Pompeu Fabra University.

507 Advisory Council for the National Transition, Report No. 10, The constitutional process, (2014) pp. 28-33.

508 Scottish Government, Scotland's Future: Your Guide to an Independent Scotland, (2013) Chapter VII, pp. 271-273. 
nationals residing in Spain who have been born or resident in Catalonia for a minimum period or whose parents are Catalans, as currently defined in Article 7(1) of the Catalan Statute of Autonomy; and Spanish nationals residing abroad who had their last administrative residence in Catalonia as well as their descendants, if they have retained the Spanish nationality, together with those Spanish nationals residing abroad and whose parents are Catalans - according to Article 7(1) of the Catalan Statute of Autonomy.

The only specific reference made to the situation of migrants is the following:

"It would be necessary to establish explicit provisions on the rules applicable to foreign residents from other countries; these provisions should be based on the principle that these people will continue to enjoy the rights that they already have, especially work and residence permits". ${ }^{099}$

Thus, citizens from other EU Member States and citizens from nonEU States would be ineligible for citizenship ab initio in a hypothetical independent Catalonia, but nonetheless they were eligible to vote on the independence query. Paradoxically, those who were enfranchised to vote on the decision of independence would be disenfranchised in the process of independence or the constitutional process.

In May 2016, Constituïm, a group consisting of professionals from several different fields, delivered a draft proposal on a Catalan constitution to the President of the Catalan Parliament. The text of this Constitution was inspired by other non-official constitutional proposals and the contributions of citizens collected via Constituïm's website. ${ }^{510}$ The draft, although it has not been officially debated in the Catalan Parliament, includes several provisions pertaining to the Catalan nationality. Article 13, under the heading of "nationality", has a similar wording to Article 11 of the Spanish Constitution. It states that the Catalan nationality is acquired, retained and lost in accordance with the provisions of the law (Article 13(1)), that no person of Catalan origin may be deprived of his or her nationality (Article 13(2)) and it also foresees the possibility to conclude treaties or agreements of dual nationality with other States (Article 13(3)). ${ }^{511}$ Remarkably, the last paragraph of Article 13 contains

509 Advisory Council for the National Transition, Report No. 10, The constitutional process, (2014) p. 32.

510 For further information about Constituïm, see: http://constituim.cat.

511 The original text reads as follows: "1. La nacionalitat catalana s'adquireix, es conserva i es perd d'acord amb el que estableixi la llei. Es pot adquirir per naixement, filiació, adopció, matrimoni, residència o bé per opció. 
a general formula according to which nationals of other countries that have "common cultural and linguistic ties with Catalonia" 512 are eligible for Catalan nationality without renouncing their nationality. This provision addresses mainly Spanish and French nationals coming from what is called Països Catalans (Catalan Countries). ${ }^{513}$

A transitional provision also regulates the acquisition of Catalan nationality at the moment of independence:

"All those citizens who on the date of declaration of independence have Spanish nationality and Catalan administrative residence, or those who can prove their usual legal residence in Catalonia for a period of more than 5 years, are recognised as Catalans of origin to all effects and purposes, without prejudice to their right to renounce it if they wish to preserve their Spanish nationality and Spanish legislation makes dual nationality incompatible". ${ }^{514}$

This Constitutional proposal makes it possible for foreign citizens residing in Catalonia to acquire Catalan nationality ab initio. However, it seems that there is a differentiation between Spanish nationals residing in Catalonia and non-Spanish nationals residing in Catalonia at the moment of independence, since the possibility to renounce the Catalan nationality is conferred only on Spanish nationals, if Spanish legislation would not allow for dual Spanish-Catalan nationality. Furthermore, those non-Spanish nationals have to provide proof of their residence in Catalonia, which is not required in the case of Spanish nationals.

2. Els catalans d'origen no poden ser privats en cap cas de la seva nacionalitat.

3. La República pot concertar tractats o convenis de doble nacionalitat amb tots els estats que reconeguin el principi de reciprocitat. En aquests estats, els catalans es poden naturalitzar sense perdre la seva nacionalitat d'origen". Full text available at: http://constituim.cat/index.php/text articulat/.

512 Translation by the author. The original text reads as follows "Els ciutadans d'altres estats que tinguin nexes culturals i lingüístics comuns amb Catalunya poden optar per la nacionalitat catalana sense haver de renunciar a la seva nacionalitat, encara que el principi de reciprocitat no es reconegui en el seu Estat".

513 The term Països Catalans is used to refer to the territories where different varieties of the Catalan language are spoken, i.e., Aragon, the Balearic Islands and Valencia in Spain, Roussillon in France, Andorra and even the city of Alghero in Italy.

514 Translation by the author. The original text reads as follows "Tots aquells ciutadans que a la data de la declaració d'independència tinguin la nacionalitat espanyola $i$ el veïnatge administratiu català o els que acreditin la residència habitual legal a Catalunya per un termini superior als 5 anys, són reconeguts com a catalans d'origen a tots els efectes, sens perjudici del seu dret a renunciar-hi, si desitgen conservar la nacionalitat espanyola i la legislació espanyola fes incompatible la doble nacionalitat". 
From an international law perspective (and leaving aside the question of the legality of the referendum or consultation under Spanish law), reference has been made in the previous chapter to certain documents that offer some guidance with regard to the attribution of nationality upon secession. ${ }^{515}$ Although questions on nationality are to be governed by the domestic law of the States involved, certain restrictions are imposed by international law conventions ${ }^{516}$ such as the $\mathrm{ECN}^{517}$ and the Convention on the Avoidance of Statelessness in Relation to State Succession. ${ }^{518}$ Although Spain and other EU Member States dealing with secessionist movements (i.e. the United Kingdom and Belgium) have not ratified these conventions, the principles enshrined in the above-mentioned conventions could be taken into consideration as guidelines, together with the Declaration on the Consequences of State Succession for the Nationality of Natural Persons ${ }^{519}$ and the Draft Articles on Nationality of Natural Persons in Relation to the Succession of States. ${ }^{520}$

The ECN establishes, as a basic rule, that the States concerned should regulate nationality matters amongst themselves in accordance with Article $19 .{ }^{521}$ In the case of Spain and Catalonia this would require assuaging the tense relationship between the Spanish central Government and the Generalitat de Catalunya. Apart from the set of general principles

515 See on this issue Guayasén Marrero González, "The role of migrants in the Catalan independence process: a legal analysis", Pro-independence Movements and Immigration: Discourse, Policy and Practice, Roberta Medda-Windischer and Patricia Popelier (eds.), 2016, pp. 161-207. Notice that the analysis on the attribution of nationality in an international legal context in this context has been already published in this contribution to Pro-independence Movements and Immigration: Discourse, Policy and Practice.

516 Paula García Andrade, "La ciudadanía europea y la sucesión de Estados: a vueltas con las implicaciones de una separación territorial en el seno de la UE”, Revista de Derecho Comunitario Europeo, 49, 2014, p. 1001.

517 Council of Europe, European Convention on Nationality (Strasbourg, 6 November 1997) ETS 166.

${ }^{518}$ Council of Europe, Convention on the Avoidance of Statelessness in Relation to State Succession (Strasbourg, 15 March 2006) CETS 200.

519 European Commission for Democracy through Law, Declaration on the Consequences of State Succession for the Nationality of Natural Persons, adopted by the European Commission for Democracy through Law at its 28th Plenary Meeting (Venice, September 1996).

520 International Law Commission, Draft Articles on Nationality of Natural Persons in Relation to the Succession of States (3 April 1999) Supplement No. 10 (A/54/10).

521 In cases of State succession, States Parties concerned shall endeavour to regulate matters relating to nationality by agreement amongst themselves and, where applicable, in their relationship with other States concerned. Such agreements shall respect the principles and rules contained or referred to in this chapter. Article 19, Council of Europe, European Convention on Nationality, supra footnote 517. 
to be respected at all times, ${ }^{522}$ Chapter VI of the ECN that deals with State succession and nationality is also relevant. ${ }^{523}$ That chapter sets out four specific principles to take into account when determining nationality: a genuine and effective link; habitual residence; the will of the individual; or the territorial origin of the individual. ${ }^{524}$ Regrettably, the ECN offers no guidance on the weighing of these factors. However, it can be concluded that the Catalan proposal, as foreseen in the Advisory Council for the National Transition Report No. 10, takes into account the four principles mentioned in Chapter VI of the ECN. In the case of the Constitutional proposal, it appears to follow these principles although it is arguable that the reference to "common cultural and linguistic ties" could be a strong enough effective link to justify the granting of Catalan nationality.

The Convention on the Avoidance of Statelessness in Relation to State Succession, although primarily concerned with statelessness, establishes minimum standards that States should observe. However, these minimum standards are confined to situations where statelessness is the result, and therefore the Convention does not mandate or suggest how nationality should be granted. For instance, the successor State should grant nationality to certain nationals of the predecessor State if they would otherwise become stateless. ${ }^{525}$ These persons are those habitually resident in the successor State, those with a legal bond to it through federal citizenship, those born there, or having their last habitual residence there before leaving the predecessor State. ${ }^{526}$ The predecessor State is not to withdraw its nationality from any of its nationals who have not acquired the nationality of the successor State, and who would otherwise become stateless. ${ }^{527}$ The proposal of the Advisory Council for the National Transition is in line with the provisions of the Convention on the Avoidance of Statelessness in Relation to State Succession since it foresees the granting of the initial Catalan nationality to Spanish citizens who are resident in a municipality of Catalonia, that is nationals of the predecessor State habitually residing in the successor State, Spanish nationals residing in Spain who have been born in Catalonia, nationals of the predecessor State born in the successor

522 Basically the nationality principles of the Universal Declaration of Human Rights (no arbitrary deprivation of nationality and the right to have a nationality and, consequently, avoidance of statelessness). Furthermore, the principle of equal treatment between men and women has to be observed.

${ }^{523}$ Chapter VI, Council of Europe, European Convention on Nationality, supra footnote 517.

${ }^{524}$ Ibid., Article18(2).

525 Article 5, Council of Europe, Convention on the Avoidance of Statelessness in Relation to State Succession.

526 Ibid., Article 5(2).

527 Ibid., Article 6. 
State, and Spanish nationals residing abroad who have had their last administrative residence in Catalonia - nationals of the predecessor State having their last habitual residence in the successor State before leaving the predecessor State. Similarly, the Constitutional proposal is in line with this Convention, since it foresees the granting of the initial Catalan nationality to Spanish nationals residing in Catalonia.

Notwithstanding these propositions, it is necessary to highlight again the limited scope of the Convention on the Avoidance of Statelessness in Relation to State Succession; its application is confined to situations where statelessness would otherwise be the result and in relation to persons who, at the time of the State succession, possessed the nationality of the predecessor State. ${ }^{528}$ Consequently, non-Spanish nationals would not fall under the scope of application of this Convention, if Catalonia were to achieve independence.

The Declaration on the Consequences of State Succession for the Nationality of Natural Persons provides a more detailed guideline for the distribution of nationality in a State succession scenario. ${ }^{529}$ In terms of the successor State, a hypothetical independent Catalan State would be obliged to grant its nationality to all nationals of the predecessor State residing permanently in the Catalan territory. ${ }^{530}$ Additionally, the Declaration deems it "desirable" that citizenship shall be available to nationals of the predecessor "originating from" the territory of the successor State, but not resident there, ${ }^{531}$ as well as permanent residents from third States. ${ }^{532}$ In respect of the former, the proposal of the Advisory Council for the National Transition makes such citizenship available by option and, in respect of the latter, the proposal is silent. The Constitutional proposal makes Catalan nationality available to both groups: Spanish nationals residing in Catalonia and nationals of other countries residing in Catalonia for a period of five years. However, the situation of Spanish nationals originating from Catalonia but residing elsewhere is not addressed in that proposal.

528 Ibid., Article 1(e).

529 The Declaration on the Consequences of State Succession for the Nationality of Natural Persons adopted by the European Commission for Democracy through the Law - the Venice Commission - attempted to draft a set of principles that serve as guidelines for State practice on nationality matters that can arise in a State succession scenario. See Chapter 2, section 5.2.

530 Para. 8(a), Council of Europe, Declaration on the Consequences of State Succession for the Nationality of Natural Persons.

531 Ibid., Para. 9(a).

532 Ibid., Para. 9(b). 
With regards to the Draft Articles on Nationality of Natural Persons in relation to the Succession of States, ${ }^{533}$ Part II identifies different situations of succession, with different rules applicable to each: the transfer of part of the territory; the unification of States; the dissolution of a State; and the separation of part or parts of the territory. In this section, focus is placed on the separation of part of the territory, since Spain would be considered the continuing State and Catalonia the separating part of the Spanish State. With regard to the acquisition of Catalan nationality, the rules repeat the residence criteria. ${ }^{534}$ That is, a presumption of nationality according to which the citizens of the predecessor State habitually resident in the territory affected by the succession of States are presumed to acquire the nationality of the successor State on the date of such succession. Article 24 stipulates that citizens of a predecessor State habitually resident elsewhere and who have "an appropriate legal connection" to a successor State should be offered the citizenship of that successor State and this offer of citizenship should be subject to a right of choice. In this sense, the Catalan proposal of the Advisory Council for the National Transition seems to fit reasonably well. Regarding citizens of third States, there is no such obligation to offer the nationality of the successor or the predecessor State, the Draft Articles only stipulate that the status as habitual residents should not be affected by the succession of States, but refers only to "persons concerned", i.e., nationals of the predecessor State..$^{535}$

Hence, from an international law perspective, while an independent Catalan State could extend an offer of citizenship to migrants, it would not be required to do so. Why then should migrants be franchised for the consultation yet not be offered citizenship ab initio? Authors such as Montserrat Guibernau ${ }^{536}$ have stated that participation in a referendum on Catalan independence should be limited to Catalan citizens - according

533 The ILC adopted the Draft Articles on Nationality of Natural Persons in Relation to the Succession of States at its fifty-first session, in 1999. At its fifty-fifth session, in 2000, the General Assembly took note of the Articles, the text of which was annexed to the resolution, inviting Governments to take into account, as appropriate, the provision contained therein in dealing with the relevant issues. However, due to the non-reaction of the governments to the request of the General Assembly on the advisability of elaborating a legal instrument on the question, the Draft Articles did not reach conventional status. See Chapter 2, section 5.1.

534 Article 24(a), ILC, Draft Articles on Nationality of Natural Persons in Relation to the Succession of States.

535 See Article 14 of the Draft Articles on Nationality of Natural Persons in Relation to the Succession of States in conjunction with the definition of "persons concerned" as provided in Article 2.

536 Montserrat Guibernau, "Catalonia: Will Catalans be permitted to hold a legally binding referendum on independence?", Kick-off contribution, European University Institute, Robert Schuman Centre for Advanced Studies, Florence, 2014, pp. 21-22. 
to the current definition in the Catalan Statute of Autonomy- and only they should be granted the Catalan nationality on day one of an independent Catalonia. It is difficult to agree with this statement since that would envisage disenfranchising a significant portion of the total population residing in Catalonia or, to put it differently, disenfranchising a considerable amount of persons that will be affected by the independence itself. ${ }^{537}$ Notwithstanding this criticism, Guibernau also highlights that " $a$ new naturalisation policy for long-term residents should make citizenship available after 5 years of residence" ${ }^{538}$ However the Advisory Council for the National Transition made no mention of a special naturalisation policy or option for long-term residents. Only the non-official draft Constitutional proposal makes it possible for foreign citizens residing in Catalonia to acquire the Catalan nationality ab initio.

Besides the aforementioned report and the draft Constitution from Constituïm, no more information about nationality policy has been made publicly available. For individuals, and especially migrants, a vote in the referendum or consultation would have to be an informed one, and a lack of understanding as to who would be citizens after any vote does not seem an acceptable situation. This position even appears to contradict the Catalan migration policy, which is developed in four-year plans; the last one entitled "Citizenship and migration plan: Horizon 2016" ${ }^{539}$ For the first time, this plan includes a programme aiming to inform the migrant population about the "national transition". ${ }^{540}$ Surprisingly (or not), due to the general lack of information regarding migrants, the plan merely highlights that an information and awareness program about the national transition for the migrant population is needed in order to promote their participation in the new Catalan State.

537 According to the last official data from the Spanish national statistics institute (INE in its Spanish acronym), 1,020,631 non-Spanish nationals are residing in Catalonia. The total population of Catalonia on January 2016, including non-Spaniards, is 7,508,106.

${ }^{538}$ Ibid., p. 22. Note that Spain requires as a general rule, a period of 10 years of residence. However, some exceptions are made to this general period. See Chapter 2, section 6.4.

539 Generalitat de Catalunya, Pla de Ciutadania i de les Migracions: horitzó 2016 (September 2014) available at: http://www20.gencat.cat/docs/bsf/03Ambits\%20 tematics/05Immigracio/03Politiquesplansactuacio/pla ciutadania immmigracio/PCM 2013-2016.pdf.

540 Ibid., pp. 49-50. 


\subsection{Flanders}

\subsubsection{Introductory Remarks on an Independence Query in Flanders}

No referendum or consultation on the independence of Flanders has, at the time of writing, been held. Thus the analysis of the eligibility to vote in a hypothetical referendum is more challenging (if not impossible) than in the cases of Catalonia and Scotland. As pointed out in section 3.3, the independence of Flanders presents unique characteristics creating the need for a different approach to the State succession that may take place in Belgium. Flanders, unlike Catalonia and Scotland, has a strong position within the Belgian State; it possesses the majority of Belgium's population and controls most of its wealth. ${ }^{541}$ Furthermore, the NieuwVlaamse Alliantie governs not only the Flemish region but it is also the leading party in the federal government. The position of power enjoyed by the Nieuw-Vlaamse Alliantie, together with the fact that Belgium has already gone very far in its devolution by granting a lot of competences to the federal Regions; may explain the reason why the nationalists of the Nieuw-Vlaamse Alliantie are not very keen on pushing for independence, despite that its political manifesto is very clear on this point, i.e., the party must strive for an independent Flanders. ${ }^{542}$ This would also explain why there is absolutely no pressure to adhere to the 2006 Convention on the Avoidance of Statelessness in Relation to State Succession, although this would probably help the Flemish case for independence. Given this scenario, it will come as no surprise that no referendum or independence query has been called for in Flanders, despite the leading position of the Nieuw-Vlaamse Alliantie and its electoral success in both the regional and federal governments.

Even the more right-wing nationalist party, the Vlaams Belang, has not expressed a clear preference for calling a referendum on the independence of Flanders. In 2010, Gerolf Annemans (current MEP and former president of the Vlaams Belang) and Steven Utsi (coordinator of the daily work of the study service of Vlaams Belang) published a blueprint on the dissolution of

541 According to the website of the Directorate-general Statistics of Belgium (in French, Direction générale Statistique et Information économique, in Dutch Algemene directie Statistiek en Economische informatie Generaldirektion Statistik und Wirtschaftinformation and in German Statistisches Landesamt), in January 2015 there were 11,209,044 inhabitants in Belgium. The population is allocated as follows: 6,444,127 inhabitants in Flanders, 3,589,744 inhabitants in Wallonia and $1,175,173$ inhabitants in Brussels. Thus, more than half of the total population in Belgium live in Flanders. All the figures and statitics are available at http://statbel. fgov.be/.

542 See section 3 of the current chapter. 
Belgium under the title De ordelijke opdeling van Belgie. ${ }^{543}$ In this blueprint the authors reached the following conclusion: since referenda have a purely consultative character, as international practice demonstrates, and are not a sufficient condition for granting independence, "the Flemish Parliament remains the only instrument through which our dream of independence can or should be realized". ${ }^{44}$ Thus, the preferred route for achieving Flemish independence is not based on a referendum, but rather on a declaration of sovereignty made by the Flemish Parliament.

\subsubsection{Eligibility for Flemish Nationality ab initio in a Potential New Flemish State}

The Nieuw-Vlaamse Alliantie has not released any proposal regarding the first determination of Flemish nationals or, more generally, any indication of a future nationality policy in an independent Flanders.

However, the Vlaams Belang addresses in the blueprint De ordelijke opdeling van België the question of who will become Flemish nationals upon independence. The Flemish nationality will be granted automatically to all former Belgian nationals who reside in a Flemish city or municipality, the decisive factor to gain the Flemish nationality being "the person's regular place of residence at the moment of the declaration of independence". ${ }^{45}$

${ }^{543}$ Gerolf Annemans and Steven Utsi, De ordelijke opdeling van België, Uitgeverij Egmont (ed.), Brussels, 29 October 2010, 1st edition, 11 June 2012, 5th edition. See also the English version of this publication: Gerolf Annemans and Steven Utsi, After Belgium, the orderly split-up, Uitgeverij Egmont (ed.), Brussels, 8 June 2011, 3rd edition. It is remarkable that the 4th (Dutch version) edition of 6 December 2011 was forbidden by the Court of Brussels (Brusselse rechtbank van koophandel). See Gerolf Annemans and Steven Utsi, De ordelijke opdeling van België, Uitgeverij Egmont (ed.), 11 June 2012, 5th edition, p. 4.

544 Gerolf Annemans and Steven Utsi, After Belgium, the orderly split-up, Uitgeverij Egmont (ed.), Brussels, 8 June 2011, 3rd edition, p. 211. In the fifth edition of the Dutch version, this is formulated as follows: "De auteurs [...] zien dus het 'eigen' Vlaams Parlement als instrument om deze potentieel woelige periode daadkrachtig te leiden in de richting van een Ordelijke Opdeling van deze hopeloze 'failed state' België- uit de negentiende eeuw". See Gerolf Annemans and Steven Utsi, De ordelijke opdeling van België, Uitgeverij Egmont (ed.), Brussels, 11 June 2012, 5th edition, p. 341.

545 Gerolf Annemans and Steven Utsi, After Belgium, the orderly split-up, Uitgeverij Egmont (ed.), Brussels, 8 June 2011, 3rd edition, p. 207. The Dutch text of the 5 th edition on this issue reads: "Kunnen in ieder geval als Vlaamse staatsburgers worden beschouwd: zij die gedomicilieerd zijn in een Vlaamse stad of gemeente én voorheen de Belgische nationaliteit bezaten". See Gerolf Annemans and Steven Utsi, De ordelijke opdeling van België, Uitgeverij Egmont (ed.), Brussels, 11 June 2012, 5th edition, p. 334. 
Against the general trend of acceptance/tolerance of dual nationality by the Belgian State, the proposal for automatic acquisition of the Flemish nationality upon independence "ought to be restricted so that the acquirer cannot claim another nationality".546 The authors refer to the possibility of holding another nationality, together with the Belgian one, as an "anomaly". ${ }^{47}$ Thus, granting Flemish nationality as described by Annemans and Utsi would amount, in practice, to loosing Belgian nationality and, therefore, EU citizen status. ${ }^{548}$ Paradoxically, when analysing the EU membership question, the authors acknowledge that it is unclear whether "an independent Flanders would be able to count on automatic EU membership. We must assume Flanders would have to request membership" ${ }^{549}$ Thus, excluding the possibility of holding a dual nationality from the onset also implies the exclusion of the possibility of holding the EU citizenship status currently triggered by the possession of Belgian or another EU Member State's nationality, in case such a nationality still exists after the Flemish independence.

Belgian nationals living outside Belgium who were born in Flanders or have recently resided in Flanders would qualify for Flemish nationality, 550 together with their children. ${ }^{51}$ Regarding naturalisation of nationals from

546 Gerolf Annemans and Steven Utsi, After Belgium, the orderly split-up, Uitgeverij Egmont (ed.), Brussels, 8 June 2011, 3rd edition, p. 207. In the Dutch version, this is formulated as follows: "Het verkrijgen van de Vlaamse nationaliteit moet derhalve behelzen dat de verkrijger uitdrukkelijk afstand doet van een andere nationaliteit". See Gerolf Annemans and Steven Utsi, De ordelijke opdeling van België, Uitgeverij Egmont (ed.), Brussels, 11 June 2012, 5th edition, p. 335.

547 Gerolf Annemans and Steven Utsi, After Belgium, the orderly split-up, Uitgeverij Egmont (ed.), Brussels, 8 June 2011, 3rd edition, p. 207. The Dutch version reads on this issue: "Bijkomend kan van de gelegenheid gebruik worden gemaakt om af te rekenen met bipatriditeit". See Gerolf Annemans and Steven Utsi, De ordelijke opdeling van België, Uitgeverij Egmont (ed.), Brussels, 11 June 2012, 5th edition, p. 334.

548 This is the more the case because the citation from the Dutch version given in footnote 546 indicates that one has to give up another nationality (een andere nationaliteit), which obviously would also include nationalities of other EU Member States. For instance, a dual Spanish-Belgian national, according to this proposal, would have to give up both nationalities in order to acquire Flemish nationality.

549 Gerolf Annemans and Steven Utsi, After Belgium, the orderly split-up, Uitgeverij Egmont (ed.), Brussels, 8 June 2011, 3rd edition, p. 126. Compare Gerolf Annemans and Steven Utsi, De ordelijke opdeling van België, Uitgeverij Egmont (ed.), Brussels, 11 June 2012, 5th edition, p. 170.

550 Gerolf Annemans and Steven Utsi, After Belgium, the orderly split-up, Uitgeverij Egmont (ed.), Brussels, 8 June 2011, 3rd edition, p. 207. Compare Gerolf Annemans and Steven Utsi, De ordelijke opdeling van België, Uitgeverij Egmont (ed.), Brussels, 11 June 2012, 5th edition, p. 335.

551 See on the position of minors regarding rules on transmission of nationality from 
other States residing in Flanders in the moment of independence, the proposal is silent.

Remarkable is the lack of details of the proposal, especially where such strong statements are given in relation to automatic acquisition of Flemish nationality upon independence.

It also worth mentioning some proposals envisage the creation of a "sub-nationality" within Brussels, linked to the language division, which entails that Belgian nationals living in Brussels would need to make a choice between a "Flemish" or a "French" sub-nationality. This idea was put forward, inter alia, by Van Wauwe in $1970^{552}$ and, more recently, by Storme in $2009 .{ }^{553}$ Van Wauwe provides a detailed set of rules on granting "la sub-nationalité flamande" or "la sub-nationalité wallonne". The Flemish or Walloon sub-nationality is acquired at birth according to the place of residence of the parents or the father, in case both parents do not have a common residence. ${ }^{554}$ Those Belgian nationals born in Brussels acquire Flemish or Walloon sub-nationality of his or her father, if he was born or is residing in Flanders or Wallonia. If the father was born in Brussels, the criterion to grant sub-nationality is the language in which the father was educated in. In case of bilingual education of the father, a special joint commission (commission paritaire) would decide which sub-nationality is granted. ${ }^{555}$ Remarkable is the role given to the commission paritaire and the weight of the paternal side over the maternal side as a criterion to grant sub-nationality. ${ }^{556}$ Similarly, Storme advocates the creation of a subnationality in Brussels as a solution to the fact that all Brussels residents are taxed the same, but the returns are distributed among the Communities

parents to children Chapter 5, section 5.

552 Ludo Van Wauwe, Federalisme, utopie ou possibilité?, Editions scientifiques Erasme - Libraire Generale de Droit et de Jurisprudence (ed.), Antwerp, Brussels, Paris, 1970.

${ }_{553}$ Matthias E. Storme, In Flanders Fields, blog entry 30 March 2009, avalaible at http://vlaamseconservatieven.blogspot.nl/2009/03/gemeenschapskeuze.html.

554 Ludo Van Wauwe, Federalisme, utopie ou possibilité?, Editions scientifiques Erasme - Libraire Generale de Droit et de Jurisprudence (ed.), Antwerp, Brussels, Paris, 1970, p. 166.

555 Ludo Van Wauwe, Federalisme, utopie ou possibilité?, Editions scientifiques Erasme - Libraire Generale de Droit et de Jurisprudence (ed.), Antwerp, Brussels, Paris, 1970, p. 166.

556 However, note that in 1970 equal treatment of men and women was not yet introduced in Belgian nationality law. That happened only in 1985. The CEDAW which obliges to treat men and women equally in respect of the transmmission of nationality to children was not yet adopted at that time. See UN General Assembly, Convention on the Elimination of All Forms of Discrimination Against Women, 18 December 1979, UNTS vol. 1249, p. 13. 
without taking into account the Flemish or French origin of the Belgian nationals residing in Brussels.

\subsection{Scotland}

\subsubsection{Eligibility to Vote in the Independence Query}

According to section 2 of the Scottish Independence Referendum (Franchise) Act 2013, British citizens (as defined in section 18 of the British Nationality Act 1981) resident in Scotland, Commonwealth citizens resident in Scotland, citizens of the Republic of Ireland, and citizens other EU countries resident in Scotland were eligible to vote in the Scottish independence referendum. The key deviation from normal voting arrangements was that the minimum age for voting in the referendum was reduced to 16 instead of 18 . This meant that persons who were 16 years old by 18 September 2014, and were otherwise eligible, could register to vote. In this regard, the reduction of the voting age to 16 is a common feature of both the Catalan and the Scottish independence query, though it is notable that the Scottish Act excluded all non-residents in the territory of Scotland. And furthermore, third country nationals were not entitled to vote in the referendum.

\subsubsection{Eligibility for Scottish Nationality ab initio in a Potential New Scottish State}

The SNP, as the main drivers behind Scottish independence, has been active in promulgating definitions of Scottish citizenship. The White Paper "Scotland's Future: Your Guide to an Independent Scotland" released in November 2013 set out the prospective nationality policy of the SNP, if Scotland were to gain independence. However, this is not the first document published by the SNP dealing with an eventual Scottish nationality. In the second half of the twentieth century, the so-called "Draft Constitution for an Independent Scotland"557 set out a broad, residence-based criterion for Scottish citizenship, according to which

"all persons who were domiciled in Scotland at the time of the promulgation of this Constitution shall be citizens of Scotland. Thereafter the acquisition of and loss of Scottish citizenship shall be determined by law, but no person who is a citizen of any other country

557 A Draft Constitution for an Independent Scotland, Scottish Provisional Constituent Assembly (1957-1964), under the direction of Roland E. Muirhead. 
can be a citizen of Scotland except in cases where the National Assembly by a unanimous resolution shall confer Honorary Citizenship". 558

As can be discerned, this draft Constitution for Scotland embraced the most common approach towards dual nationality at that moment, ${ }^{559}$ which contrasts with the current position. ${ }^{560}$ In 1997, "The Parliament and Constitution of an Independent Scotland" 561 was released. This document maintained the broad grant of Scottish nationality based on residence, adding a broader entitlement by way of birth:

"The right of Scottish citizenship will belong to all those resident in Scotland on the date of Independence and to those who were born in Scotland but are resident elsewhere. The Constitution will allow naturalisation as a Scottish citizen and protect the residency and other rights of those living in Scotland who do not take Scottish citizenship or are citizens of other nations" ${ }^{562}$

In 2002, another document further elaborated on the Scottish nationality proposal of the SNP: "A Constitution for a Free Scotland" ${ }^{53}$ Scottish nationality would also be granted by way of descent, including individuals whose parents were born in Scotland. The document also contained certain safeguards to protect those residents who may not wish to acquire Scottish citizenship.

\section{"4 Citizenship}

(a) Every person whose principal place of residence is in Scotland at the date at which this Constitution comes into force shall be a citizen of Scotland, and shall remain so until such time, if any, as he or she shall renounce such citizenship.

(b) Every person whose place of birth was in Scotland or either of whose parents was born in Scotland, being a person who is alive at

558 A Draft Constitution for an Independent Scotland, Scottish Provisional Constituent Assembly (1957-1964), Article 2.

559 Although the United Kingdom already adopted such a positive attitude in 1949.

560 The 2013 White Paper "Scotland's Future: Your Guide to an Independent Scotland" reflects that new approach to dual nationality: "We plan that British citizens habitually resident in Scotland on independence will be considered Scottish citizens. This will include British citizens who hold dual citizenship with another country (...) The Scottish Government will also allow dual citizenship".

561 The Parliament and Constitution of an Independent Scotland, February 1997, SNP.

562 The Parliament and Constitution of an Independent Scotland, February 1997, SNP, p. 3.

563 A Constitution for a Free Scotland, SNP policy paper, September 2002. 
the date at which this Constitution comes into force, shall be a citizen of Scotland, and shall remain so until such time, if any, as he or she shall renounce citizenship.

(c) As soon as is reasonably possible after the date at which this Constitution shall come into force, the Parliament of Scotland shall enact legislation making further provision as to citizenship, which shall inter alia prescribe:

(i) What formal steps shall be required to constitute voluntary renunciation of citizenship

(ii) What conditions and procedures shall be necessary to acquisition of Scottish citizenship by naturalisation, and

(iii) What future provision shall be made as to acquisition of Scottish citizenship by birth or by marriage, provided that no law may be passed whereby any person who is or at any time becomes a Scottish citizen may be deprived of that citizenship save by a voluntary act of renunciation, which may include, but only if and insofar as Parliament shall so prescribe by legislation, acquisition of or voluntary continuation in the exercise of, citizenship of any other state or states; nor may any law concerning the acquisition of citizenship be discriminatory on any such ground as sex, race, colour, religion, personal beliefs, abilities, status, or sexual orientation.

(d) Adopted children shall for purposes of citizenship be treated as though they had been born to their adoptive parents.

(e) All persons whose principal place of residence is in Scotland at the date at which this constitution comes into force shall have the right to continue in residence in Scotland, and to return to residence in Scotland after any period or periods of absence, whether they exercise or renounce their rights to Scottish citizenship; and all children under the age of eighteen years whose parents' principal residence is in Scotland at the date at which this constitution comes into force shall have the same rights to residence and to citizenship as though they had been resident in Scotland at that date. No law may be passed under which any person's existing right of residence may be extinguished by any means other than voluntary renunciation".564

564 A Constitution for a Free Scotland, SNP policy paper, September 2002, pp. 10 and 11. 
The 2013 White Paper "Scotland's Future: Your Guide to an Independent Scotland" maintains the same basic criteria as the 2002 document: residence, birth and parents' birth. The Scottish nationality is granted automatically to British citizens habitually resident in Scotland "on day one of independence" and British citizens born in Scotland but living outside of Scotland "on day one of independence". ${ }^{65}$ After independence, the proposal sets out the automatic acquisition of the Scottish nationality to those born in Scotland to at least one parent who has Scottish citizenship or indefinite leave to remain at the time of their birth and those born outside Scotland to at least one parent who has Scottish citizenship.

Prima facie, although the criteria to automatically acquire Scottish nationality did not change in the current proposal, one can observe certain limitations on its application. For first time, the term "habitually resident" is used. The proposal clarifies what has to be understood by "habitually resident":

"The term has been equated with the term "ordinarily resident" which is currently used to define "settled in the UK" in the British Nationality Act 1981. [Note: "settled" is defined by the British Nationality Act 1981 as requiring ordinary residence AND without being subject under immigration laws to any restriction on the period for which the person may remain i.e. a person with indefinite leave to remain.] The test for ordinary residence is satisfied where the person has habitually and normally resided for a settled purpose apart from temporary or occasional absences. "Settled purpose" is defined as one which has "a sufficient degree of continuity to be properly described as settled"',"'566

Further to this, the birth criterion is limited: the existence of a prior connection to Scotland via nationality of at least one of the parents was required in order to acquire the nationality by birth.

Finally, British nationals living outside Scotland with at least one parent who qualifies for Scottish citizenship can register as a Scottish citizen (so long as they can provide the requisite evidence to substantiate their claim) and non-British nationals who have a parent or grandparent who qualifies for Scottish citizenship can register as a Scottish citizen (again, so long as they can provide the requisite evidence to substantiate their claim).

565 Scotland's Future: Your Guide to an Independent Scotland, Scottish Government, November 2013, p. 271.

566 Note that the 2002 Draft Constitution for a free Scotland used the criterion "principle place of residence", whereas the older Muirhead draft Constitution used the common law concept of domicile. For further elaboration on the notion of domicile see: Richard Fentiman, "Domicile Revisited", The Cambridge Law Journal, 50, 1991, pp. 445-463. 
Regarding naturalisation, migrants in Scotland may only apply for Scottish nationality "subject to meeting good character, residency and any other requirements set out under Scottish immigration law". ${ }^{567}$ More specifically, citizens of any country who have spent at least ten years living in Scotland at any time and have an on-going connection with Scotland may apply for Scottish nationality, also subject to "meeting good character, residency and any other requirements set out under Scottish immigration law".568 The Scottish proposal seems, at first sight, not to be that generous when compared with the period of residence currently required in the British Nationality Act, which is 5 years of residence. ${ }^{569}$ However, the British Nationality Act 1981 requires 5 years of residence immediately preceding the application for naturalisation, whereas the requirement of the Scottish proposal is also satisfied if the residence requirement was fulfilled in the past, provided there is evidence on an on-going connection with Scotland. The proposal does not, however, indicate how that on-going connection should be evidenced.

\section{Concluding Remarks}

Catalonia, Flanders and Scotland have maintained unique historical, cultural, economic and political identities within the States of which they are part. These regions have benefitted from a devolution process within their respective States, achieving an important level of internal selfdetermination. However, this seems not to be enough for the nationalist parties and for a significant portion of the population supporting independence. None of these regions have become an independent State. Far from these independence movements being stifled, however, the independence movements maintain their momentum, especially in Catalonia and Scotland.

Only two out of the three regions analysed in this research have held a referendum/consultation on independence. Leaving aside the question of the legality of such queries from the domestic legal perspective (which is of extreme relevance for the case of Catalonia), some discernible features can be highlighted.

First, it is notable how the electorate was selected in both the Catalan consultation and the Scottish referendum. In the latter, British citizens,

567 Scotland's Future: Your Guide to an Independent Scotland, Scottish Government, November 2013, p. 273.

568 Scotland's Future: Your Guide to an Independent Scotland, Scottish Government, November 2013, p. 273.

569 BNA Schedule 1, section 1(2) available at http://www.legislation.gov.uk/ ukpga/1981/61. 
Commonwealth citizens, citizens of the Republic of Ireland, and citizens of other EU countries resident in Scotland were eligible to vote, so long as they satisfied the age requirement. Third country nationals were not permitted to vote.

In the case of the Catalan "participatory process" and, following the intervention of the Spanish Constitutional Court, not only regional electors (Catalan people) residing in Catalonia and outside of Catalonia - excluding those living in the rest of the Spanish territory - could cast their vote; but also non-Spanish citizens meeting the age requirement who could prove their residence in Catalonia were eligible to vote. From the onset, the Catalan electorate seemed more open to the participation of third country nationals in the independence process. However, when analysing the proposal for the $a b$ initio determination of Catalan nationals, this participation is limited to casting a vote in the independence consultation. Third country nationals fell outside of the scope of the Catalan proposal on granting initial Catalan nationality. Consequently, third country nationals who are enfranchised to vote in the decision of independence would be disenfranchised in the process of independence or the constitutional process. This lack of congruence between eligibility to vote and the $a b$ initio determination of nationals of the newly independent State, although permissible under international law, seems rather reprehensible due to the possible reification of third country nationals in independence referendums.

In both cases (Catalonia and Scotland), the age requirement was reduced to 16 years, allowing minors to participate in the independence decisionmaking process. This can raise difficult issues at a later stage, however, since the $a b$ initio determination of nationals of an eventual Catalan or Scottish independent State and the operation of the laws on the extension of the acquisition of nationality and loss of nationality from parents to minors. $^{570}$

Flanders represents a special case in this context, since no referendum/ consultation has been held on the question of independence and no elaborated proposals on Flemish nationality can be ascertained.

570 See further: Chapter 5, section 5. 


\section{Chapter 4: State Succession in the EU. EU Citizenship and Nationality Law}

\section{Introduction}

In previous chapters the international rules dealing with nationality in a State succession scenario and membership of international organisations have been examined. At the domestic level, the Catalan and Scottish proposals dealing with nationality have also been analysed. ${ }^{571}$ It is this previous analysis which therefore serves as the starting point of the current chapter, whereby the European dimension is addressed.

There is no relevant precedent, when reviewing the territorial changes that have taken place in the EU territory, which can be applied by analogy to the Spanish, Belgian or British cases. ${ }^{572}$ Neither the German reunification, the independence of Algeria, ${ }^{573}$ the withdrawal of Greenland ${ }^{574}$ nor the most recent example of Saint Barthélemy ${ }^{575}$ can be fully compared to the scenario of a European part of a Member State seceding. Catalonia, Flanders and Scotland thus pose a question for which the EU has no direct precedent. Although the Treaties have provided for an accession procedure for States to join the $\mathrm{EU}^{576}$ and, after Lisbon, to withdraw, ${ }^{577}$ there is no provision in the Treaties to address the secession of a devolved region of a Member State that wishes to remain within the EU as an independent Member State. In this context, the culmination of a process of that nature in Catalonia, Flanders or Scotland differs considerably from previous territorial changes that have taken place within the European Union.

The independence of a part of the territory of an EU Member State and its accession to the EU itself will have a significant impact on the enjoyment

571 Together with some remarks for an eventual Flemish nationality, although there is no official proposal from the Nieuw-Vlaamse Alliantie. See Chapter 3, sections 5.1.2, 5.3.2 and 5.2.2.

572 See Chapter 1 , section 1.

573 The Algerian case comes the closest to the situation at stake. However, this precedent took place in 1962, long before the Treaty on European Union first introduced the legal concept of citizenship of the Union and the freedoms attached to that status. See Chapter 1, section 1.

574 See Chapter 1 , section 1.

575 See Chapter 1 , section 1.

576 Article 49 TEU, Treaty on European Union (Consolidated Version), OJ C (326) 55, 26 October 2012.

577 Article 50 TEU, Treaty on European Union (Consolidated Version), OJ C (326) 55, 26 October 2012. 
of one of the major achievements of European integration, i.e., the status of citizen of the Union. The enjoyment of that status by nationals of Member States involved in an independence or separation process could be jeopardised as a result of the eventual loss of the nationality of that Member State. Likewise, European citizens of other nationalities residing in the territory of the new States would also be affected by State succession, because their capacity as citizens of the Union would not guarantee them free movements rights in the territory of the newly independent State. The same could apply for third country nationals, citizens of non-EU Member States residing in these new States, who also enjoy certain set of rights by the operation of EU law. ${ }^{578}$

In the following section the situation of these three groups of people is addressed in the light of EU law and the case law of the CJEU.

\section{EU citizenship vs. Member State Nationality}

The Maastricht Treaty ${ }^{579}$ introduced the concept of citizenship of the Union twenty-five years ago. However, the status of citizen of the Union which comprises of rights, inter alia, to enter, to reside and to stay in the territory of another Member State, is the result of a longer process that is rooted in the history of free movement of labour. Chapter VII of the Treaty establishing the European Coal and Steel Community ${ }^{580}$ obliged the Member States to remove restrictions on employment based on the nationality of workers in the steel and coal industries. ${ }^{581}$

578 See Dimitry Kochenov, "Ius Tractum of Many Faces: European Citizenship and the Difficult Relationship between Status and Rights", Columbia Journal of European Law, Vol. 15, No. 2, 2009, pp. 222-233.

579 European Union, Treaty on European Union (Consolidated Version), Treaty of Maastricht, 7 February 1992, OJ C (191) 1; 29 July 1992.

580 Treaty establishing the European Coal and Steel Community, Paris, 18 April 1951 (not published in $O$ ).

581 Treaty establishing the European Coal and Steel Community, Paris, 18 April 1951 (not published in 0), Article 69: "1. The member States bind themselves to renounce any restriction based on nationality against the employment in the coal and steel industries of workers of proven qualifications for such industries who possess the nationality of one of the member States; this commitment shall be subject to the limitations imposed by the fundamental needs of health and public order.

2. In order to apply these provisions, the member States will work out a common definition of specialities and conditions of qualification, and will determine by common agreement the limitations provided for in the preceding paragraph. They will also work out technical procedures to make it possible to bring together offers of and demands for employment in the Community as a whole.

3. In addition, for the categories of workers not falling within the provisions of the preceding paragraph and where an expansion of production in the coal and steel 
The Treaty of Rome ${ }^{582}$ significantly expanded the personal scope of the freedom of movement to all workers, except for those employed in the public service. ${ }^{583}$ This treaty gave all workers the right to accept offers of employment, to move freely amongst the Member States for this purpose, to reside in any Member State if employed there, and to stay in any Member State if formerly employed there. Furthermore, the freedom of establishment was introduced for the first time at the Treaty of Rome. ${ }^{584}$

In December 1973, at the Copenhagen European Summit, the Heads of State or Government of the nine Member States of the enlarged European Community affirmed their determination to introduce the concept of European identity into their common foreign relations. ${ }^{585}$ Following the European Summit held in Paris in December 1974, whereby the Member States endeavoured to "study the conditions and the timing under which the citizens of the nine Member States could be given special rights as members of the Community" ${ }^{586}$ the Commission subsequently presented a report entitled "Towards European Citizenship".587 The report examined the

industries might be hampered by a shortage of qualified labor, they will adapt their immigration regulations to the extent necessary to eliminate that situation; in particular, they will facilitate the reemployment of workers from the coal and steel industries of other member States.

4. They will prohibit any discrimination in remuneration and working conditions between national workers and immigrant workers, without prejudice to special measures concerning frontier workers; in particular, they will work out among themselves any arrangements necessary so that social security measures do not stand in the way of the movement of labor.

5. The High Authority shall guide and facilitate the application by the member States of the measures taken by virtue of the present article.

6. The present article shall not interfere with the international obligations of the member States".

582 Treaty establishing the European Economic Community, Rome, 25 March 1957 (not published in 0 ).

583 Treaty establishing the European Economic Community, Rome, 25 March 1957 (not published in 0 ), article 48.

584 Treaty establishing the European Economic Community, Rome, 25 March 1957 (not published in O), article 53 .

585 Declaration on European Identity, Copenhagen, 14 December 1973, Bulletin of the European Communities, December 1973, No 12. Luxembourg: Office for official publications of the European Communities, pp. 118-122.

586 Point 11 of the communiqué issued after the European Summit held in Paris in December 1974. Meeting of the Heads of Government, Paris, 9-10 December 1974, Bulletin of the European Communities, December 1974, No 12.

587 Towards European Citizenship (lmplementation of point 11 of the final communiqué issued at the European Summit held in Paris on 9 and 10 December 1974). The granting of special rights (Report presented by the Commission to the Council on 3 July 1975), Commission of the European Communities, Bulletin of the European 
conditions under which the Member States could grant "special rights", i.e., a set of political rights to vote, to stand for election and to become public officials in other Member States. ${ }^{588}$ The Commission highlighted that European citizenship implies that citizens of a Member State "would automatically be entitled to be treated in another Member State as if he were citizen of that State" ${ }^{589}$ for the purpose of exercising those "special rights". It is also remarkable that the report discouraged facilitating naturalisation of nationals of other Member States since "in the view of the probable development of the Community this possibility involving a simple exchange of nationality seems less promising than the idea of equality with the nationals of the host State". ${ }^{590}$

As a follow up of the Paris Summit, in 1977 the European Parliament adopted a Resolution on the granting of special rights to citizens of the European Community, the purpose of which was to implement the decision of the Paris Summit of December 1974 (point 11 of the final communique). ${ }^{591}$ In 1979 the Commission published a Proposal for a Council Directive on a right of residence for nationals of Member States in the territory of another Member State..$^{592}$

However, no significant steps towards the creation of European citizenship were taken until the Single European Act (SEA) was adopted in 1986. According to Willem Maas, the lack of progress on this issue was due the increased immigration of third country nationals into the Community; but also due to the election, in May 1979, of Margaret Thatcher as British Prime Minister. Other reasons for the lack of progress on European citizenship were that Greece joined the Community in 1981 and that accession negotiations were already underway with Portugal in June 1978

Communities, Supplement 5/75, COM (75) 321 final, Brussels, 2 July 1975, pp. 2632.

588 Towards European Citizenship (lmplementation of point 11 of the final communiqué issued at the European Summit held in Paris on 9 and 10 December 1974). The granting of special rights (Report presented by the Commission to the Council on 3 July 1975), Commission of the European Communities, Bulletin of the European Communities, Supplement 5/75, COM (75) 321 final, Brussels, 2 July 1975, p. 29.

589 Ibid., p. 32.

590 Ibid., p. 32.

591 Resolution on the granting of special rights to be citizens of the European Community in implementation of the decision of the Paris Summit of December 1974 (point 11 of the final communiqué), European Parliament, OJ C (299) 26, 12 December 1977.

592 Proposal for a Council Directive on a right of residence for nationals of Member States in the territory of another Member State (submiited by the Commission to the Council on 31 July 1979), Council of the European Comunities, COM (79) 215 final, OJ C (207), 17 August 1979, pp. 14-16. 
and subsequently with Spain in February $1979 .{ }^{593}$ The accession of these two countries, especially Spain, was decisive for the establishment of the citizenship of Union..$^{54}$

In 1984 the European Parliament passed a Resolution on the draft Treaty establishing the European Union, ${ }^{595}$ in which the preliminary draft of that treaty was approved. Article 3 of the draft stated that:

"The citizens of the Member States shall ipso facto be citizens of the Union. Citizenship of the Union shall be dependent upon citizenship of a Member State; it may not be independently acquired or forfeited. Citizens of the Union shall take part in the political life of the Union in the forms laid down by this Treaty, enjoy the rights granted to them by the legal system of the Union and be subject to its laws."

Before the approval of the SEA, in 1985 the Commission released a White Paper on "Completing the Internal Market", which dedicated a section to the "Free movement of labour and the professions: a new initiative in favour of Community Citizens" which aimed to ensure free movement for all individuals, regardless of their economic position, as the core of European citizenship. ${ }^{596}$ In 1986, although the SEA codified into law much of Commission's White Paper, ${ }^{597}$ the provisions regarding "Community Citizens" did not share the same fate.

The old Member States did not radically alter their positions on European citizenship between the SEA and Maastricht negotiations. However, it was the accession of new Member States (that had no opportunity to vote on the SEA) that altered the outcome of the Maastricht conference: "Spain and, to a lesser extent, Portugal were key actors promoting the notion of European citizenship". ${ }^{598}$

593 Willem Maas, Creating European Citizens, Rowman \& Littlefield Publishers, Lanham, 2007, p. 34.

594 On this particular issue, see: Willem Maas, Creating European Citizens, Rowman \& Littlefield Publishers, Lanham, 2007, p. 96.

595 Resolution on the draft Treaty establishing the European Union (14 February 1984), European Parliament, OJ C (77) 53, 19 March 1984.

596 Completing the Internal Market. White Paper from the Commission to the European Council (Milan, 28-29 June 1985), Commission of the European Comunities, COM (85) 310 final, 14 June 1985, available at http://ec.europa.eu/white-papers/pdf/ com85-310-internal-market en.pdf.

597 Willem Maas, Creating European Citizens, Rowman \& Littlefield Publishers, Lanham, 2007, p. 39.

598 Willem Maas, Creating European Citizens, Rowman \& Littlefield Publishers, Lanham, 2007, p. 40. 
In 1991, the European Parliament adopted a Resolution on Union citizenship. ${ }^{599}$ The European Parliament stipulated that EU citizenship should be additional to national citizenship, and that it should be placed within the framework of the ECHR. The Resolution further stipulated that third-country nationals should also enjoy rights under EU law.

On 9 and 10 December 1991 the intergovernmental convention was held in Maastricht, which ultimately led to the signing of the Treaty on European Union on 7 February 1992. Article 8 of the Treaty read as follows:

\section{Citizenship of the Union is hereby established. Every person holding the nationality of a Member State shall be a citizen of the Union.}

\section{Citizens of the Union shall enjoy the rights conferred by this Treaty and shall be subject to the duties imposed thereby.}

Citizenship of the Union, as established by the Maastricht Treaty, conferred upon nationals of the Member States the right to move and reside freely within the territory of the Member States; ${ }^{600}$ the right to vote and to stand as a candidate at municipal elections in the Member State in which he/she resides, under the same conditions as nationals of that State; ${ }^{601}$ the right to vote and to stand as a candidate in elections to the European Parliament in the Member State in which he/she resides, under the same conditions as nationals of that State; ${ }^{602}$ the right to diplomatic protection by the diplomatic or consular authorities of any Member State in the territory of a third country in which the Member State of which he/she is a national is not represented; ${ }^{603}$ and the right to petition the European Parliament. ${ }^{604}$

Since matters relating to nationality fall within the exclusive competence of the Member States, it will come as no surprise that concerns arose regarding the relationship between the nationality of the Member States and the newly created citizenship of the Union. The Conference of the Representatives of the Governments of the Member States adopting the Treaty of Maastricht annexed to the final act a Declaration addressing this issue $^{605}$ the wording of which was as follows:

599 Resolution on Union citizenship (14 June 1991), European Parliament, OJ C (183), 15 July 1991, pp. 473-476.

600 Article 8(a) Maastricht Treaty.

601 Article 8(b)(1) Maastricht Treaty.

602 Article 8(b)(2) Maastricht Treaty.

${ }^{603}$ Article 8(c) Maastricht Treaty.

${ }^{604}$ Article 8(d) Maastricht Treaty.

605 Declaration no 2 annexed to the Treaty of Maastricht on nationality of a Member State (OJ 1992 c 191, p. 98). 
"The Conference declares that, wherever in the Treaty establishing the European Community reference is made to nationals of the Member States, the question whether an individual possesses the nationality of a Member State shall be settled solely by reference to the national law of the Member State concerned. Member States may declare, for information, who are to be considered their nationals for Community purposes by way of a declaration lodged with the Presidency and may amend any such declaration when necessary".

Along the same line, Denmark adopted a declaration on citizenship of the Union on the occasion of the Danish ratification of the Treaty of Maastricht, ${ }^{606}$ which stated:

"Citizenship of the Union is a political and legal concept which is entirely different from the concept of citizenship within the meaning of the Constitution of the Kingdom of Denmark and of the Danish legal system. Nothing in the Treaty on European Union implies or foresees an undertaking to create a citizenship of the Union in the sense of citizenship of a nation-state. The question of Denmark participating in any such development does, therefore, not arise."

That concern about the relationship between nationality of the Member States and citizenship of the Union and the autonomy of the first over the latter is also reflected in the rewording of the original Article 8 of the Treaty on European Union (Treaty of Maastricht) and current Article 20(1) of the TFEU.

The Treaty of Amsterdam ${ }^{607}$ added the following sentence to the treaties: "Citizenship of the Union complements and does not replace national citizenship". ${ }^{608}$ The Treaty of Amsterdam also added the so-called right to information for citizens of the Union. Thus every European citizen and any natural or legal person having its registered office in a Member State is entitled to access to European Parliament, Council of the European Union. ${ }^{609}$

606 Declaration on citizenship of the Union, to be associated to the Danish act of ratification of the Treaty on European Union, [1992] OJ C 348/1.

607 Treaty on European Union (Consolidated version), Treaty of Amsterdam, 2 October 1997, OJ C (340) 10 November 1997.

608 Treaty on European Union (Consolidated version), Treaty of Amsterdam, 2 October 1997, OJ C (340) 10 November 1997, article 17.

609 Treaty on European Union (Consolidated version), Treaty of Amsterdam, 2 October 1997, OJ (C 340) 10 November 1997, article 21, para. 3. 
The Treaty of Nice ${ }^{610}$ did not change the wording of the EU citizenship provision. However, a new milestone linked to European citizenship was reached in the framework of the negotiations that took place during the Intergovernmental Conference in Nice: the Charter of Fundamental Rights of the European Union was solemnly proclaimed. ${ }^{611}$ Chapter V of the Charter is devoted to Citizens' rights, i.e., right to vote and to stand as a candidate at elections to the European Parliament and at municipal elections, right to good administration, right to access to documents, right to apply to the Ombudsman, right to petition the European Parliament, freedom of movement and of residence and entitlement to diplomatic and consular protection. The Charter did not have any legally binding effect until its adoption on 12 December 2007 in Strasbourg, one day before the Treaty of Lisbon was signed. With the entry into force of the Treaty of Lisbon, on 1 December 2009, the Charter became legally binding on the EU institutions and Member States, and it currently has the same legal status as the treaties.

The Treaty of Lisbon ${ }^{612}$ amended the changes brought about by the Treaty of Amsterdam. Hence, the wording was changed from "Citizenship of the Union complements and does not replace national citizenship" to "Citizenship of the Union shall be additional to and not replace national citizenship". This is the current wording of Article 20(1) TFEU. After the entry into force of the Lisbon Treaty citizenship of the Union is governed by the following provisions: 1) Title II of the TEU, entitled "Provisions on democratic principles" (Articles 9 to 11 TEU); 2) The second part of the TFEU entitled "Non-discrimination and citizenship of the Union" (Articles 20 to 22 TFEU) and Article 15(3) TFEU; 3) Charter of Fundamental Rights of the European Union which, according to Article 6(1) of the TEU, has the same legal value as the Treaties, achieving the status of EU primary law. It is remarkable that the declaration on nationality of a Member State as attached to the Maastricht Treaty was removed as an annex of the TEU after the entry into force of the Lisbon Treaty.

\section{CJEU case law}

In this section, the case law of the CJEU is described and analysed. It follows from the jurisprudence of the CJEU that the Court has imposed certain limitations on the autonomous powers of the Member States

610 Treaty on European Union (Consolidated version), Treaty of Nice, 26 February 2001, OJ (C 80) 10 March 2001.

611 Charter of Fundamental Rights of the European Union, [2010] OJ C 83/389.

${ }^{612}$ Treaty of Lisbon Amending the Treaty on European Union and the Treaty Establishing the European Community, 13 December 2007, OJ C 306/01, 17 December 2007. 
to determine issues relating to the acquisition and loss of nationality. Special attention will therefore be paid to those limitations, which may be important in the context of a State succession scenario. In that scenario, what would be important is the reactions of the remaining Member State to the independence of part of its territory vis-à-vis nationality issues.

\subsection{Mario Vicente Micheletti and Others v Delegación del Gobierno en Cantabria ${ }^{613}$}

Dual citizenship has undoubted relevance for the purposes of the enjoyment of the status of European citizenship in the context of State succession. Holding two nationalities could be attractive for nationals of the new States (i.e. a Catalan, Flemish or Scottish State) provided that they retain the nationality of the predecessor EU Member State (i.e. the nationality of Spain, Belgium or the United Kingdom). However, this solution may not be possible. This is due to the fact that the newly independent State could make the acquisition of its nationality conditional on the loss of the previous nationality ${ }^{614}$ Similarly, although more questionable in the light of the light of Rottmann decision, ${ }^{615}$ the predecessor State could withdraw its nationality ex lege to all those residing in the territory of the new State and who acquire the nationality of that new State.

Furthermore, it may be considered that, in cases of dual nationality, the effective nationality is the nationality of the successor State due to the existence of an effective link between the individual and that State. However, for the purposes of EU law, a national of a Member State who is also a national of a non-member State is also an EU citizen because he or she holds the nationality of a Member State.

${ }^{613}$ Case C-369/90, Micheletti [1992] ECR I-04239. For further analysis on this case, see: Alegría Borrás Rodríguez, "Jurisprudencia del Tribunal de Justicia de las Comunidades Europeas", Revista Jurídica de Catalunya, 1993, pp. 584-587; Nuria Bouza I Vidal, "El ámbito personal de aplicación del derecho de establecimiento en los supuestos de doble nacionalidad: comentario a la Sentencia del TJCE de 7 julio de 1992 en el caso Micheletti c. Delegación del Gobierno de Cantabria (As. C-369/90)", Revista de Instituciones Europeas, 1993, pp. 563-581; José Maria Espinar Vicente, "La "resolución"de los conflictos de nacionalidad en el Derecho comunitario", La ley Comunidades Europeas, 1994, no. 84, pp. 1-5; Gerard-René de Groot, "Negeert Spanje de Micheletti-beslissing van het Europese Hof van Justitie?", Migrantenrecht, 1998, pp. 123-124; José Luis Iglesias Buhigues, "Doble nacionalidad y Derecho comunitario: A propósito des asunto C-369/90, Micheletti, sentencia del TJCE de 7 julio de 1992", in: Hacia un nuevo orden internacional y europeo. Estudios en homenaje al profesor don Manuel Díez de Velasco, Tecnos, Madrid 1993, pp. 953-967; and Hans-Ulrich Jessurun d'Oliveira, "Case note", Common Market Law Review, 1993, pp. 623-637.

614 The loss can be an ex lege loss or by declaration of renunciation.

615 See on Rottmann section 3.5 of the present Chapter. 
In Micheletti the CJEU dealt with the case of a dual Argentinian-Italian who sought to exercise the freedom of establishment in Spain and whose request to establish a business in Spain was denied by the Spanish authorities on the basis that his effective nationality was the Argentinian one.

According Article 9 of the Spanish Civil Code, in cases of dual nationality, where neither nationality is Spanish, the effective nationality is deemed to be that nationality corresponding to the habitual residence of the person concerned before his arrival in Spain. The Court considered that in cases of dual nationality, the nationality of one Member State is sufficient to trigger the operation of a provision of EU law (at the time of the decision Community law) concerning freedom of establishment. Furthermore, the time at which or the manner in which the nationality was acquired did not matter. The same applies for the fact that the person who relies on it is, at the same time, the holder of another nationality. Thus, the Court held that

"provisions of Community law on freedom of establishment preclude a Member State from denying a national of another Member State who possesses at the same time the nationality of a non-member country entitlement to that freedom on the ground that the law of the host State deems him to be a national of the non-member country". 616

Consequently, in cases of dual nationality, the predecessor State cannot rely on its own rules of private international law regarding the choice of applicable law to deny the application of EU law to a European citizen. ${ }^{617}$ Importantly, the Court also found that Member States, in the exercise of their powers in nationality matters, must pay due regard not only to international law but also to EU law ("having due regard to Community law"). ${ }^{618}$ Thus, while the Court acknowledged the power of the Member States to establish the conditions for the acquisition and loss of nationality, it is also clear that EU law imposes a limitation on this power. However, the CJEU did not further elaborate on which principles of EU law should be regarded by Member States when laying down the conditions for the acquisition and loss of nationality. Further clarification on the phrase "having due regard to Community law" was provided, however, by the Court in the Rottmann ruling. ${ }^{619}$

616 Case C-369/90, Micheletti [1992] ECR I-04239, para. 15.

617 Note that the Micheletti decision was issued before the concept of citizen of the Union, introduced by the Maastricht Treaty, came into force.

${ }_{618}$ Case C-369/90, Micheletti [1992] ECR I-04239, para. 10.

619 For further elaboration on the Rottmann ruling, see section 3.5 of the present Chapter. 


\subsection{The Queen and Secretary of State for the Home Department v Manjit Kaur $^{620}$}

The Kaur decision analysed the link between the EU citizenship and the possession of the nationality of a Member State for the purposes of the enjoyment of the rights attached to EU citizenship.

Mrs Kaur was a Citizen of the United Kingdom and Colonies under the British Nationality Act 1948. Following the entry into force of the British Nationality Act 1981, her status became that of a British Overseas Citizen. As such, she had no right under national law to enter or remain in the United Kingdom, although she was residing in the United Kingdom on the basis of temporary leave. The refusal of the British authorities to grant Mrs Kaur indefinite leave to remain in the United Kingdom, led to a preliminary ruling before the CJEU. The Court concluded in this case that:

"in order to determine whether a person is a national of the United Kingdom for the purposes of Community law, it is necessary to refer to the 1982 Declaration by the Government of the United Kingdom of Great Britain and Northern Ireland on the definition of the term 'nationals which replaced the 1972 Declaration by the Government of the United Kingdom of Great Britain and Northern Ireland on the definition of the term 'nationals', annexed to the Final Act of the Treaty concerning the Accession of the Kingdom of Denmark, Ireland and the United Kingdom of Great Britain and Northern Ireland to the European Communities".621

Due to this Declaration, the Court arrived at the conclusion that Mrs Kaur never acquired European citizenship in the first place, and consequently rejected her claim since she could not be deprived of a status that she never possessed.

In arriving at this conclusion, the Court made a clear distinction between situations which fall into the scope of (then) Community law and purely internal situations. Thus, according to Advocate General Léger, the entry and residence of a national of a Member State within the territory of another Member State falls within the scope of Community law; while "that

${ }^{620}$ Case C-192/99, Kaur [2001] ECR I-01237. See Stephen Hall, “Determining the Scope ratione personae of European Citizenship: Customary International Law Prevails for Now. ECJ Judgment, 20 February 2001, Case C-192/99, The Queen v. Secretary of State for the Home Department ex parte Kaur", Legal Issues of Economic Integration, 2001, pp. 355-360 and Prakasch Shah, "British Nationals under Community Law: The Kaur Case", European Journal of Migration and Law, 2001, pp. 271-278.

621 Case C-192/99, Kaur [2001] ECR I-01237, para. 27. 
national's entry and residence in his own territory, which are based on the rights attendant upon his nationality" remains in the Member State sphere of competence. ${ }^{622}$ Thus, since citizenship of the Union shall complement and not replace national citizenship, there is a distinction between the competences of the Member States and the competences of the EU in relation to the rights and duties that an individual may acquire by reason of his or her nationality. The relationship that a national has with her or his State of origin in regard to rights of entry and residence must therefore, in principle, remain within that Member State's sphere of competence. "It follows that citizenship of the Union is relevant in the present case only within the context of free movement between Member States". ${ }^{623}$

A restrictive interpretation of the Kaur ruling in the context of a State succession may lead to the conclusion that EU law will be applicable only to situations in which nationals of the predecessor EU Member State have exercised free movement rights within the EU. Thus, the predecessor EU Member State will not be constrained by the application of EU law when its nationals are residing in a non-EU Member State (e.g., Spanish nationals residing in Catalonia) or in the territory of the EU Member State itself (e.g., Spanish nationals residing in Spain). However, nationals of the predecessor EU Member State possess the status of European citizens, at least until the moment of independence. This fact alone, would be enough to trigger the application of EU Law, on the basis that there must be "due regard to Community law" when enacting new nationality legislation in the context of an eventual independence of part of the territory of Member State. Accordingly, the findings of the Court in Kaur should be read together with the ruling of the CJEU in the Rottmann case.

In any case, it would still be within the competence of the predecessor EU Member State to define who its nationals are and, consequently, who enjoys the status of citizen of the Union. However, in the exercise of that exclusive competence, Member States are not completely autonomous, as can already be concluded from the Micheletti decision. ${ }^{624}$ Again the dichotomy between the competences of the Member States in the field of nationality and the constraints that may be imposed by EU law were reiterated in the Kaur decision.

${ }^{622}$ Opinion of Advocate General Léger, in Case C-192/99, Kaur [2000] ECR I-01239, para. 27.

${ }^{623}$ Opinion of Advocate General Léger, in Case C-192/99, Kaur [2000] ECR I-01239, para. 27.

${ }^{624}$ For further elaboration on Micheletti see section 3.1 of the present Chapter. 


\subsection{Kunqian Catherine Zhu, Man Lavette Chen v Secretary of State for the Home Department ${ }^{625}$}

Catherine Zhu was born in 2000 in Northern Ireland, to Chinese parents. The fact that she was born on that territory was a deliberate decision. Firstly, her parents already had one child, born in the People's Republic of China, so they tried to obviate the Chinese birth control policy by having the second child born abroad. Secondly, at the time of Catherine's birth, the Republic of Ireland applied a ius soli criterion for the acquisition of Irish nationality and, therefore, the desire for Catherine to possess European citizenship status was also intended:

"Mr and Mrs Chen decided to arrange for their child to be born in Belfast. They intended to take advantage of the child's Community nationality in order to ensure that she and her mother would be able to establish themselves in the United Kingdom". ${ }^{.626}$

Catherine acquired Irish nationality as planned ${ }^{627}$ and, as a result, citizenship of the Union. However, she did not acquire British citizenship as she did not meet the requirements laid down in the relevant United Kingdom legislation. ${ }^{628}$ Catherine and her mother moved to the United Kingdom and applied for residence permits, which were rejected. It was that rejection that led to the preliminary ruling before the CJEU.

Case C-200/02, Zhu and Chen [2004] ECR I-09951. See further: Catherine Barnard, "Of Students and Babies", The Cambridge Law Journal, 2005, pp. 560-563; Bernhard Hofstötter, "A cascade of rights, or who shall care for little Catherine? Some reflections on the Chen case", European Law Review, 2005, pp. 548-558; Bjorn Kunoy, "A Union of National Citizens: the Origins of the Court's Lack of AvantGardisme in the Chen Case", Common Market Law Review, 2006, pp. 179-190 and Alina Tryfonidou, "C-200/02, Kunqian Catherine Zhu and Man Lavette Chen v. Secretary of State for the Home Department: Further Cracks in the "Great Wall" of the European Union?", European Public Law, 2005, pp. 527-541.

${ }^{626}$ Opinion of Advocate General Tizzano, in Case C-200/02, Zhu and Chen [2004] ECR I-09951, para. 13.

627 Under section 6(1) of the Irish Nationality and Citizenship Act of 1956, which was amended in 2001 and applied retroactively as from 2 December 1999, Ireland allowed at the time of the birth of Catherine Zhu, any person born on the island of Ireland (including Northern Ireland) to acquire Irish nationality.

${ }^{628}$ The United Kingdom abolished pure ius soli in 1981. The child of foreigners born on British territory since then only acquires British citizenship by virtue of birth in the United Kingdom if her/his father or mother is settled in the United Kingdom, i.e. has there ordinary residence without being subject under the British immigration laws to any restriction on the period for which (s)he may remain. See section 1(1) (b) juncto section 50(2) British Nationality Act 1981. Entered into force 1 January 1983. Case C-200/02, Zhu and Chen [2004] ECR I-09951, para. 10. 
It is worth noting that, at least in the proceedings before the CJEU, the acquisition of the Irish nationality by Catherine was not questioned, although the shadow of a possible abuse of law extended over the facts of the case. In any case, and following the lines already sketched in Kaur and Micheletti, the CJEU held that it is for each Member State, having due regard to Community law, to lay down the conditions for the acquisition and loss of nationality and, therefore, it is not permissible for a Member State to restrict the effects of the grant of the nationality of another Member State with a view to the exercise of fundamental freedoms provided for EU law. In this case, the right of Catherine to reside in the United Kingdom could not be denied merely because her Irish nationality "was in fact acquired solely in order to secure a right of residence under Community law for a national of a non-member country". ${ }^{629}$

The Court concluded that Catherine had the right to reside in the United Kingdom by operation of Directive 90/364 on the right of residence. ${ }^{630}$ As regards her mother, the Court considered that since she was the primary carer of the minor who has the right to reside as a citizen of the Union in the United Kingdom (so long as certain conditions laid down by EU law could be fulfilled) it was enough to extend that right to Catherine's parents. To rule otherwise, would have deprived the child's residence of any useful effect.

This ruling could play a role in a State succession scenario, to secure the residence rights of the parent that acquired the nationality of newly independent non-EU State provided that the child holds the nationality of a Member State (the predecessor State or another Member State) and the parent is the primary carer. This decision is of particular importance in light of the possible strategic decisions that may need to be taken within families affected by the State succession in order to keep a certain status under EU law or in order to guarantee the continuation of certain residence rights. ${ }^{631}$ It is not entirely unforeseeable that, due to the operation of the nationality legislation enacted upon independence, the parents of a minor end up having a different nationality than that of their child. A strategic move in this case would be the following: the minor living in a EU Member

${ }^{629}$ Case C-200/02, Zhu and Chen [2004] ECR I-09951, para. 40.

${ }^{630}$ Council Directive 90/364/EEC of 28 June 1990 on the right of residence OJ L (180), 13 July 1990 (repealed by Directive 2004/38/EC of the European Parliament and of the Council of 29 April 2004 on the right of citizens of the Union and their family members to move and reside freely within the territory of the Member States amending Regulation (EEC) No 1612/68 and repealing Directives 64/221/EEC, 68/360/EEC, 72/194/EEC, 73/148/EEC, 75/34/EEC, 75/35/EEC, 90/364/EEC, 90/365/EEC and 93/96/EEC).

631 See Chapter 5 , section 5 
State retains the nationality of the predecessor EU Member State and, consequently, the parent, upon the acquisition of the nationality of the newly independent State, who has lost that nationality, can therefore still derive the residence right in the EU Member State as a primary carer of the minor. However, the picture becomes more complicated if one takes into account the application of the principle of equal treatment of men and women in nationality law and the fact that minors were allowed to cast their vote in the Scottish independence referendum and in the Catalan participatory process. ${ }^{632}$

\subsection{G. Eman, O.B. Sevinger v College van burgemeester en wethouders van Den Haag ${ }^{633}$}

While the Kaur decision focused on the freedom of movement of EU citizens between Member States, the Eman case dealt with one of the socalled political rights attached to EU citizenship, i.e., the right to vote and to stand as a candidate in elections to the European Parliament. This request for a preliminary ruling had its roots in the rejection of Dutch nationals residing in Aruba for registration on the register of electors for the election of members of the European Parliament by the College van burgemeester en wethouders van Den Haag. The Dutch Electoral Law conferred the right to vote and to stand as a candidate in elections to the European Parliament to all Dutch nationals resident in the European part of the Kingdom or in a non-EU Member State, whereas such a right is not conferred on Dutch nationals resident in the Netherlands Antilles ${ }^{634}$ or Aruba. The rationale behind this exception is the fact that these territories are considered part of the Kingdom of the Netherlands, but are not considered part of the territory of the EU.

${ }^{632}$ See Chapter 3, section 2.

${ }^{633}$ Case C-300/04, Eman [2006] ECR I-08055. See Miquel Palomares Amat, "Ciudadanía de la Unión, nacionalidad y derecho de voto a las elecciones al Parlamento Europeo. Comentario a las Sentencias des TJCE de 12 de septiembre de 2006 (Asuntos C-145/04 y C-300/04)", Noticias de la Unión Europea, 2008, no. 282, pp. 43-48; Jo Shaw, "The Political Representation of Europe's Citizens: Developments", European Constitutional Law Review, 2008, pp. 162-186 and Maite Zelaia Garagarza, "La Ciudadanía de la Unión y el derecho a votar en las elecciones al Parlamento Europeo, Comentario a las Sentencias del Tribunal de Justicia de las Comunidades Europeas España c. Reino Unido, y Eman and Sevinger c. College van burgemeester en wethouders van Den Haag, de 12 de septiembre de 2006", Revista de Derecho Comunitario Europeo, 2007, pp. 91-123.

${ }^{634}$ On 1 October 2010 the Netherlands Antilles were dissolved. The islands Curaçao and Sint Maarten do now -like Aruba- have the status of a country (Land) within the Kingdom of the Netherlands, whereas the islands Bonaire, Saba and Sint Eustatius are formally part of the European part of the Kingdom, however it does not form part of the territory of the European Union. 
However, the Kingdom of the Netherlands has an indivisible nationality, meaning that Dutch nationals from Aruba, Netherlands Antilles or Dutch nationals from the European territory possess one and the same Dutch nationality and, as a result, they all are citizens of the Union. However, the right to vote and to stand as a candidate in elections to the European Parliament is not expressly and precisely defined by EU law. Former Article 19(2) TEC was confined to applying the principle of non-discrimination on grounds of nationality to that right to vote and stand for election, by stipulating that every citizen of the Union residing in a Member State of which he or she is not a national has the right to vote and to stand as a candidate in elections to the European Parliament in the Member State in which he or she resides, under the same conditions as nationals of that State. Although the Court did not find the residence criterion to be inappropriate in determining who has the right to vote and to stand as a candidate in elections to the European Parliament, the CJEU nevertheless concluded that the principle of equal treatment or non-discrimination was infringed. The reasoning behind this was that comparable situations were treated differently by the Dutch Electoral Law: a Dutch national resident in a non EU Member State had the right to vote and to stand as a candidate in elections to the European Parliament held in the Netherlands whereas a Dutch national residing in the Netherlands Antilles or Aruba not possess such a right. In practice, this led to a paradoxical situation whereby a:

"Netherlands national who transfers his residence from Aruba to a non-member country has the right to vote in the same way as a Netherlands national transferring his residence from the Netherlands to a non-member country, while a Netherlands national resident in Aruba does not have that right".635

Thus, the conditions of the right to vote and to stand as a candidate in elections to the European Parliament have to be defined by the Member States in compliance with EU law.

Consequently, in a State succession scenario, the remaining EU Member State cannot deprive the right to vote and to stand as a candidate in elections to the European Parliament of its nationals residing in the territory of the newly independent State, as far as that right is given to its nationals residing in other non-EU countries.

Also interesting for the purposes of this research is the Opinion of Advocate General Tizzano on the Eman decision and the case C-145/04. ${ }^{636}$ Both

${ }_{635}$ Case C-300/04, Eman [2006] ECR I-08055, para. 59.

${ }^{636}$ Case C-145/04, Spain v United Kingdom [2006] ECR I-07961. 
cases dealt with the right to vote and to stand as a candidate in elections to the European Parliament. ${ }^{637}$ Although the importance of the political rights attached to the EU citizenship status should not be ignored, the main focus of this research concerns residence rights. However, the effects of the eventual independence of a part of the territory of a Member State have on the enjoyment of political rights given by the EU citizenship status are obvious: individuals who lose the nationality of a Member State would lose EU citizenship and the rights associated to it, including the political rights.

\subsection{Janko Rottmann v. Freistaat Bayern ${ }^{638}$}

Dr. Janko Rottmann was born in Austria and had Austrian nationality from birth. He was prosecuted in the mid 1990s in Austria for alleged fraud, but moved to Germany in 1995, ostensibly before criminal sanctions could be applied. The Austrian courts executed a warrant for his arrest. Whilst in Germany, he sought naturalisation as a German, but without disclosing to the German authorities that he was the subject of criminal proceedings in Austria. A decision granting naturalisation was made in February 1999. As a result of acquiring German nationality, Rottmann automatically lost his Austrian nationality by operation of law.

In late 1999, the City of Munich, which had handled the request for naturalisation, was informed by the Austrian authorities about the criminal

637 The ECtHR declared in its decision Matthews v United Kingdom 18 February 1999 that the United Kingdom infringed Article 3 of Protocol No. 1 to the ECHR by failing to organise European Parliament elections in Gibraltar. Following that ruling, the United Kingdom amended its European Parliament Representation Act in order to enable inhabitants of Gibraltar to participate in elections to the European Parliament.

${ }^{638}$ Case C-135/08, Rottmann [2010] ECR I-01449. See Alegría Borrás Rodríguez and Cristina Pellisé, "Jurisprudencia del Tribunal de Justicia de la Unión Europea”, Revista Jurídica de Catalunya, 2010, p. 289-290; José Manuel Cortés Martín, “Ciudadanía de la Unión, nacionalidad de los Estados Miembros y estatuto de apatridia, STJEU (Gran Sala) de 2 marzo de 2010, Rottmann C-135/08", Revista de Derecho Comunitario Europeo, 2010 no. 36, pp. 599-602; Gerard-René de Groot and Anja Seling, "The consequences of the Rottmann judgment on Member State autonomy - The European Court of Justice's avant-gardism in nationality matters", European Constitutional Law Review, 2011, 150-160; also published in: Jo Shaw (ed): Has the European Court of Justice Challenged Member State Sovereignty in Nationality Law? (RSCAS Working Paper 2011/62), Florence: EUI 2011, pp. 27-31 (also available on: http://cadmus.eui.eu/handle/1814/19654); Dimitry Kochenov, "A Real European Citizenship: A new Jusrisdiction Test; A Novel Chapter in the Development of the Union in Europe", Columbia Journal of European Law, Vol. 18, No. 1, 2011, pp. 56-109; and Hans-Ulrich Jessurun d'Oliveira, "Decoupling Nationality and Union Citizenship?”, European Constitutional Law Review, 2011, pp. 138-149. 
proceedings against Rottmann in Austria. The German authorities took the decision to revoke the naturalisation decision on the grounds that it had been obtained fraudulently. The effect of the withdrawal of German nationality, which did not entail automatic reacquisition by Rottmann of Austrian nationality under Austrian law, would render Rottmann stateless. In addition, he would also lose his EU citizenship status and thus all the rights attached thereto. Rottmann challenged the administrative decision to withdraw nationality under German law, and the German supreme Federal Administrative Court decided to stay the proceedings before it and made a reference to the CJEU.

In this case, the Court recalled, as stated in several judgments, that "citizenship of the Union is intended to be the fundamental status of nationals of the Member States". 639 The CJEU reiterated the Micheletti formula, and accepted that the deprivation of the nationality of a Member State and therefore of EU citizenship falls within the scope of EU law. The admissibility question was disputed by some Member States in the proceedings since the rules on acquisition and loss of nationality fall within the competence of the Member States and, from the onset, the decision of the German authority to withdraw the German nationality was a purely internal situation. However, the Court stated that
"the situation of a citizen of the Union who (...) is faced with a decision withdrawing his naturalisation (...) placing him (...) in a position capable of causing him to lose the status conferred by Article [20 TFEU] and the rights attaching thereto falls, by reason of its nature and its consequences, within the ambit of European Union law" ${ }^{640}$

The next step by the Court was to assess the decision of the German authorities to withdrawal Rottmann's nationality in accordance with EU law. Despite the EU dimension, the decision taken by the German authorities was not considered contrary to EU law from the outset. The withdrawal of nationality was considered legitimate due to the deceptive acquisition of German nationality. The CJEU held that this withdrawal was in accordance with international law, ${ }^{641}$ since it was not an arbitrary act and, finally, the legitimacy of the measure was upheld even although the deprivation of nationality meant the loss of EU citizenship, provided that it was in conformity with the principle of proportionality. ${ }^{642}$ This

639 Case C-135/08, Rottmann [2010] ECR I-01449, para. 43.

640 Case C-135/08, Rottmann [2010] ECR I-01449, para. 42

${ }^{641}$ Case C-135/08, Rottmann [2010] ECR I-01449, para. 51-53.

${ }^{642}$ Case C-135/08, Rottmann [2010] ECR I-01449, para. 55-56. See also Bundesverwaltungsgericht 11 November 2010, Case 5 C12.10. See also GerardRené De Groot in Sergio Carrera Núñez and Gerard-René De Groot (eds.), European 
principle implies that the consequences for the individual and his family, the seriousness of the offence, the lapse of time between naturalisation and withdrawal and the possibility to recover the original nationality had to be taken into account.

Two main points should be highlighted from the Rottmann decision: the reasoning given by the Court in relation to the scope of application of EU law in nationality matters and the restrictions imposed by EU law in the competence of Member States to grant or withdraw their nationality. Regarding the first point, the message seems rather clear: the deprivation of the nationality of a Member State and therefore of EU citizenship constitutes a situation governed by EU law. Thus, the Rottmann doctrine is applicable not only to cases of deprivation when a fraud is discovered and statelessness is the result, but also in other cases of deprivation -even if no statelessness is caused but the EU citizenship could be lost. ${ }^{643}$

In the context of State succession, the Rottmann judgment is relevant if a State wants to provide for an ex lege loss provision. The proportionality of introducing such a rule must be assessed. The loss of nationality of an EU Member State ex lege, as a consequence of voluntarily acquiring the nationality of the newly independent State, i.e. a third State, would fall within the ambit of EU law because that would imply the loss of EU citizenship. However, the application of EU law in such a context is limited. Only the remaining EU Member State is subject to EU law. The reaction of the remaining EU Member State upon independence of a part of its territory in terms of withdrawal its nationality has to be compliant with EU law. The newly independent State, assuming that no automatic accession is possible ${ }^{644}$ is not constrained by the application of EU law. It is therefore possible to argue, in light of the EU principle of sincere cooperation and given the desire of the succeeding regions to "remain" in the EU, that a mass-naturalisation of third country nationals would be contrary to EU law. $^{645}$ However, provided that the newly independent States are not EU

Citizenship at the Crossroads, The Role of the European Union on Loss and Acquistion of Nationality, Wolf Legal Publishers, Oisterwijk, 2015, pp. 383-396.

${ }^{643}$ Gerard-René de Groot, "Survey on Rules on Loss of Nationality in International Treaties and Case Law", in Sergio Carrera Núñez and Gerard-René De Groot (eds.), European Citizenship at the Crossroads, The Role of the European Union on Loss and Acquistion of Nationality, Wolf Legal Publishers, Oisterwijk, 2015, p. 35. Also the ILEC guidelines apply the principle of proportionality to all cases of loss of nationality, see ILEC guidelines IV.5.c and V.a. See Sergio Carrera Núñez and GerardRené De Groot (eds.), pp. 600 and 601.

${ }^{644}$ See Chapter 2, section 3.

${ }^{645}$ In his Opinion, AG Maduro highlighted the relevance of the general principles of EU law in restricting the legislative power of Member States in nationality matters, 
Member States, there is no legal obligation on the part of those States, regardless of the political consequences of such a decision.

If a withdrawal of nationality that may even lead to statelessness is justified, would it not also be the case when the loss of nationality is the consequence of a voluntary acquisition of another nationality? A measure entailing the ex lege loss of nationality in this case would also be in accordance with international law and proportionality may be easier to justify than when the adverse consequence is statelessness. ${ }^{646}$ Advocate General Maduro, in his Opinion to the Rottmann case, also considered that it was not impossible to deprive a person of nationality where such deprivation would entail the loss of Union citizenship. Otherwise, that would exclude the competence of Member States to regulate nationality and lead to the "paradoxical solution whereby the secondary would determine the primary: maintenance of Union citizenship would serve as a basis for demanding maintenance of the nationality of a Member State". ${ }^{647}$

However, although the predecessor EU Member State can withdraw its nationality, this does not permit that State to do so without applying the proportionality test. Thus, the predecessor State cannot provide in its nationality law for an ex lege withdrawal of its nationality to all its nationals residing in the territory of the newly independent State. That would amount to deprivation of the EU citizenship status without applying any kind of proportionality test. A right to opt for the nationality of the predecessor State or the nationality of the newly independent State has to be provided.

\section{Maltese Citizenship-for-Sale Programme}

The Maltese citizenship-for-sale question also provides an example of the Member States' obligation to exercise its power to grant an individual's nationality in a way compatible with the principles of EU law.

In 2013, the Maltese Government announced an amendment of the Maltese Citizenship Act to sell Maltese nationality to foreign donors through an

in particular the EU principle of sincere cooperation, which in his view "could be affected if a Member State were to carry out, without consulting the Commission or its partners, an unjustified mass naturalization of nationals of non-Member States". Opinion of Advocate General Maduro, in Case C-135/08, Rottmann [2010] ECR I-01449, para. 30 .

${ }^{646}$ Phoebus Athanassiou and Stéphanie Laulhé Shaelou, "EU Accession from Within?An Introduction", Yearbook of European Law, 2014, p. 23.

647 Opinion of Advocate General Maduro, in Case C-135/08, Rottmann [2010] ECR I-01449, para. 24. 
Individual Investor Programme (IIP). The IIP granted nationality by way of a certificate of naturalisation to foreign individuals and their families, who contributed to the economic development of Malta. ${ }^{648}$ The debate around this legislative initiative caught the attention of the EU on 15 January 2014 when the European Parliament Plenary Session debated the "citizenship for sale" programme. On that occasion, Viviane Reding, Vice-President of the European Commission, highlighted that naturalisation decisions adopted by one Member State "are not neutral" with regard to others and the EU as a whole, and one should not put a price tag on citizenship of the Union. ${ }^{649}$

On 16 January 2014, the European Parliament adopted a Resolution on EU Citizenship for Sale, which condemned Member States' citizenship for sale programmes, with specific reference to the Maltese IIP. ${ }^{650}$ The European Parliament declared that the IIP undermined citizenship of the Union. The Resolution concluded that "this way of obtaining citizenship in Malta, as well as any other national scheme that may involve the direct or indirect outright sale of EU citizenship, undermines the very concept of European citizenship". ${ }^{61}$ It called upon the European Commission to provide an analysis of the legality of such schemes (for example whether these schemes respect the letter and spirit of the Treaties and the Schengen Borders Code as well as EU rules on non-discrimination) and to adopt guidelines on granting EU citizenship via national schemes and recommendations to prevent such schemes from undermining EU values.

The Parliament criticised the Maltese programme on a number of grounds. Firstly, the European Parliament opined that citizenship should not be a tradable commodity and "cannot have a price tag attached to it"; secondly, European citizenship should be dependent on people having ties with an EU Member State or ties with an EU citizen; and thirdly, the programme was critiqued on the basis that it privileges rich people over the poor, and therefore the programme may be discriminatory, as it allows only the richest third-country nationals to obtain EU citizenship, "without any other criteria being considered". ${ }^{652}$ The EP Resolution put special emphasis on

648 The IIP made Maltese nationality available to successful applicants when they donated $€ 650,000$ to the State. In addition, a donation of $€ 25,000$ was required for spouses and children below 18, and a $€ 50,000$ donation was required for dependent parents aged 55 or over, and unmarried children between 18 and 25 .

649 Viviane Reding, "Citizenship must not be up for sale", European Commission, Speech/14/18, 15 January 2014.

${ }^{650}$ European Parliament resolution on EU citizenship for sale, 2013/2995(RSP), 16 January 2014.

651 Point 1 of the Resolution.

652 Point K of the Resolution. 
the need for Member States to be cautious when exercising their national competences on matters of residency and citizenship and "to take possible side-effects into account". ${ }^{653}$ It underlined that "a number of member states have introduced schemes which directly or indirectly result in the sale of $E U$ citizenship to third country nationals", yet no specific Member States were alluded to in the Resolution. ${ }^{654}$

It appears that Reding's speech of 15 January 2014 and the favourable position of the Commission's legal service on the matter encouraged the Commission's DG Justice to proceed with infringement proceedings against Malta. A meeting took place in Brussels on 29 January 2014 between the Maltese authorities and representatives of the DG Justice of the European Commission whereby the IIP and its compatibility with EU law were discussed in detail. According to the joint press statement by the European Commission and the Maltese Authorities on the IIP, ${ }^{655}$ both parties reached a common understanding on the issues at question.

The Maltese representatives presented their intentions regarding further amendments of the IIP "with a view to clarifying that this Programme will confer full rights, responsibilities and a full citizenship status". The amendments would aim at establishing a "genuine link" to Malta through the introduction of "an effective residence status in the country" before acquiring Maltese nationality. The joint press statement stated that no naturalisation certificate would be issued unless the applicant could provide evidence of having resided in Malta for a period of at least 12 months immediately prior to the date of issuance. A particular issue of discussion was how this residency requirement would be implemented in practice, with the Commission insisting on a concept of residence similar to the one applied in the Maltese naturalisation procedures as laid down by the Maltese Citizenship Act.

The IIP was amended in February $2014^{656}$ to ensure compliance with the European Commission's demands. For the first time, the threat of infringement proceedings by the Commission led to substantive amendments of a Member State's nationality law. As Carrera Núñez

653 Point 6 of the Resolution.

${ }_{654}$ Points 12 and 13 of the Resolution.

655 European Commission, Press Release, Joint Press Statement by the European Commission and the Maltese Authorities on Malta's Individual Investor Programme (IIP), European Commission - MEMO/14/70, 29 January 2014.

656 Individual Investor Programme of the Republic of Malta Regulations, 2014, L.N. 47 of 2014, Maltese Citizenship Act (CAP. 188), B 341. See also Citizenship (Amendment) Regulations, 2014, L.N. 17 of 2014, Maltese Citizenship Act, CAP. 188. 
pointed out, ${ }^{657}$ two principal factors played a role during the negotiations between DG Justice and the Maltese authorities on the revision and the subsequent amendments of the Maltese Citizenship Act and the IIP. First, supranational legal standards and judge-made general principles of law (the "genuine link" theory as established in Public International Law according to which there must be an effective connection or some sort of tie between an individual and the State whose nationality the person acquires or possesses); ${ }^{658}$ and second, the EU principle of sincere or loyal cooperation.

Although operating more in the political rather than in the strictly legal sphere, the Maltese case shows again the relevance of the general principles of EU law in restricting the legislative power of Member States in nationality matters. In a State succession scenario, the Maltese case evidences the limitations imposed by EU law not only in cases of loss but also in cases of acquisition of nationality. Although the potential newly independent States are not bound by EU law, it would not be wise, from a political perspective, to introduce this kind of scheme upon independence.

\section{Concluding Remarks}

Nationality matters fall within the scope of competences of Member States. This is a statement that the CJEU has constantly reiterated in its judgments dealing with nationality issues. However, while the Court acknowledged the power of Member States to set up the conditions for the acquisition and loss of nationality, it has set restrictions on the competences of the Member States in this field. Its famous and cryptic phrase "having due regard to Community law" when Member States lay down the conditions for the acquisition and loss of nationality was first mentioned in the Micheletti case but it was not until the Rottmann decision was issued that the scope of that limitation was fully clarified.

The message sent by the Court was clear: due to the link between the nationality of the Member States and the citizenship of the Union, Member States are not fully autonomous when granting or withdrawing their

${ }^{657}$ Sergio Carrera, "How much does EU citizenship cost? The Maltese citizenship-forsale affair: A breakthrough for sincere cooperation in citizenship of the union?", Centre for European Policy Studies, Liberty and Security in Europe Paper No. 64, 2014, p. 20. See also Sergio Carrera Núñez and Guayasén Marrero González, "La ciudadanía europea en venta. El programa de venta de la nacionalidad maltesa: ¿una brecha en el principio de cooperación leal en el ámbito de la ciudadanía de la Unión?, (2014) 49 Revista de Derecho Comunitario Europeo, pp. 847-885.

658 Liechtenstein v Guatemala ("Re Nottebohm") [1955] International Court of Justice, Reports 4. 
nationality. The fact that, until the moment of independence, nationals of the predecessor EU Member State possess the status of European citizens, triggers the obligation to have due regarding to EU law when enacting new nationality legislation in the context of an eventual State succession. The nationality law enacted by the successor State, may lead to changes in the nationality law of the predecessor State (i.e. the EU Member State). For example, the remaining EU Member State may provide for the loss of its nationality, upon the acquisition of the nationality of the newly independent State. In case such nationality legislation is enacted, it must be established whether this is compliant with the CJEU's ruling in Rottmann.

Regarding the newly independent States, assuming that no automatic accession to the EU is legally possible, they would not bound by this restrictions imposed by EU law in the field of nationality. However, from a political point of view, it seems rather beneficial in the context of the accession negotiations to follow these EU law principles. As noted in the Maltese example, the principle of sincere cooperation is of particular importance when drafting rules on acquisition of nationality.

Holding the nationality of a Member State is still the conditio sine qua non to enjoy the European citizenship status. Thus, if that nationality is lost, European citizenship is also lost, including all the rights attached to that status, including the so-called political rights. Can the person concerned enjoy certain rights attached to the citizenship of the Union even in the case that status is no longer being held? As pointed out when analysing the Zhu and Chen decision, it may be possible to secure the residence rights of the parent in a EU Member State that acquired the nationality of newly independent non-EU State provided that the child holds the nationality of a Member State (the predecessor State or another Member State) and lives in the EU, as the primary carer of the child. However, this residence right is not automous but depends on a residence right of an EU citizen. The next chapter analyses this question, with special focus on the possible retention of residence rights as an autonomous right -not derived from the existence of family ties with EU citizens-not only by former EU citizens but also by other categories of individuals that could be affected by the State succession. 


\section{Chapter 5: State Succession and the Right to Reside Permanently}

\section{The Kurić doctrine}

In previous chapters it has been concluded that if Catalonia, Flanders and Scotland were to become independent, they would not automatically retain their EU membership, and as a consequence the EU citizenship status would be lost for those nationals of the newly independent States since they would not retain the nationality of the remaining EU Member State. However, some rights linked to the possession of Member State nationality and, by extension, to the citizenship of the Union, that are exercised at the moment of independence may be retained by some categories of people, even if Catalonia, Flanders or Scotland find themselves outside of the EU. This thesis, first developed by Vidmar in the context of the Scottish independence referendum, ${ }^{659}$ is founded not directly on EU law, ${ }^{660}$ but rather on the ECHR (which would automatically continue to apply in Catalonia, Flanders and Scotland ${ }^{661}$ and more specifically by application of the doctrine developed by the ECtHR in the case of Kurić and others $v$ Slovenia. ${ }^{662}$

\subsection{The Facts of the Case}

On 25 June 1991 Slovenia declared independence as a successor State of the Socialist Federal Republic of Yugoslavia (hereinafter, SFRY). Until that date, Slovenia was one of the six republics within the federation of Yugoslavia, together with Bosnia and Herzegovina, Croatia, Serbia, Montenegro and Macedonia. Nationals of the SFRY enjoyed "dual citizenship" for internal purposes, meaning that they were both citizens the federation and one of the six republics. ${ }^{663}$ They had freedom of movement within the federation and had the right to acquire permanent residence in any of the six republics when certain criteria were fulfilled. Achieving permanent

659 Jure Vidmar, "The Scottish Independence Referendum in an International Context," Canadian Yearbook of International Law 51, 2013, pp. 259-288.

${ }^{660}$ However, there is link between the ECHR and the Charter of Fundamental Rights of the EU via article 52.3 .

${ }^{661}$ Chapter 2, section 4. Jure Vidmar, "The Scottish Independence Referendum in an International Context," Canadian Yearbook of International Law 51, 2013, p. 282.

${ }_{662}$ Case Kurić and Others v Slovenia, Application No. 26828/06, 26 June 2012.

${ }^{663}$ On the relationship between the federal citizenship and the citizenship of the republics, see: Matjaž Tratnik, Het nationaliteitsrecht in de oosteuropese landen, Kluwer, Deventer, 1989, pp. 217 - 218. 
residence was key to fully enjoying civil, economic, political and social rights. ${ }^{664}$ The resemblance of this situation to the situation of nationals of EU Member States is salient: nationals of Member States are also citizens of the Union and, within the EU, they enjoy certain rights including, inter alia, the freedom of movement and establishment.

Table No. 4

\begin{tabular}{|c|c|}
\hline $\begin{array}{c}\text { Dual citizens (citizens of the Federation } \\
\text { and one of the six Republics) }\end{array}$ & $\begin{array}{c}\text { Nationals of an EU Member State and } \\
\text { European citizens }\end{array}$ \\
\hline $\begin{array}{c}\text { Freedom of movement within the } \\
\text { Federation }\end{array}$ & \begin{tabular}{c} 
Freedom of movement within the EU \\
\hline $\begin{array}{c}\text { Right to acquire permanent residence } \\
\text { in any of the Republics }\end{array}$
\end{tabular} \\
$\begin{array}{c}\text { Right to acquire permanent residence } \\
\text { within the territory of the EU }\end{array}$ \\
\hline
\end{tabular}

Before the independence of Slovenia, the applicants in the case were nationals of both the SFRY and one of the constituent republics other than Slovenia. All of the applicants gained permanent residence in Slovenia as SFRY nationals. At the time the application was submitted, two of the applicants were stateless and the rest retained the nationality of one of the successor States of the SFRY. None of the applicants retained their permanent resident status upon the independence of Slovenia.

As part of the independence process, Slovenia passed several laws including the Nationality Act of the Republic of Slovenia ${ }^{665}$ and the Aliens Act. ${ }^{666}$ Before independence, and according to the so-called "Statement of Good Intentions", 667 the Assembly of the Republic of Slovenia declared its intention to grant Slovenian nationality to all permanent residents on the territory of the Slovenia. Under section 40 of the Nationality Act, ${ }^{668}$

${ }^{664}$ Case Kurić and Others v Slovenia, Application No. 26828/06, 26 June 2012, para. 19.

${ }^{665}$ Citizenship of the Republic of Slovenia Act (Zakon o državljanstvu Republike Slovenije),Official Gazette nos. 1/91-I, 30/91 and 96/2002 of 1991 and 2002.

${ }_{666}$ Aliens Act (Zakon o tujcih) Official Gazette no. 1/91-I of 1991.

667 Statement of Good Intentions (Izjava o dobrih namenih) Official Gazette of the RS, no. 44/90-I of 1990.

${ }^{668}$ Citizenship of the Republic of Slovenia Act (Zakon o državljanstvu Republike 
nationals of other constituent republics of the SFRY were entitled to acquire Slovenian nationality when the following conditions were satisfied: the enjoyment of the permanent resident status in Slovenia at the date of the independence plebiscite (held on 23 December 1990) and being actually residing in Slovenia. A period of six months (expiring on 25 December 1991) was given in order to apply for Slovenian nationality, after which the ordinary naturalisation became applicable to all other former SFRY nationals. During this six month period, those nationals of other republics of the SFRY who fulfilled the aforementioned requirements had equal rights and duties with the citizens of the Republic of Slovenia

"until they acquire citizenship of Slovenia under section 40 of the Citizenship of the Republic of Slovenia Act or until the expiry of the time-limit set forth in section 81 of the Aliens Act". ${ }^{669}$

Section 81 of the Aliens Act laid down a period of two months after the expiry of the six month period to apply for the Slovenian nationality (26 February 1992) or two months after a decision issued in administrative proceedings rejecting the application for citizenship became final. ${ }^{670}$ This meant that nationals of the former SFRY Republics who did not apply for Slovenian nationality within the prescribed period or whose requests were rejected, did not enjoy "equal rights and duties to the citizens of the Republic of Slovenia" ${ }^{671}$ Instead they became aliens that fell within the personal scope of application of the Aliens Act.

In fact, on 26 February 1992, and following internal instructions from the Ministry of Inner Affairs on the implementation of the Aliens Act, ${ }^{672}$ the

Slovenije) Official Gazette nos. 1/91-I, 30/91 and 96/2002 of 1991 and 2002.

6691991 Constitutional Law relating to the Fundamental Constitutional Charter on the Sovereignty and Independence of the Republic of Slovenia (Ustavni zakon za izvedbo Temeljne ustavne listine o samostojnosti in neodvisnosti $R S$ - Official Gazette of the RS no. 1/91-I of 1991), Section 13: "Citizens of the other republics [of the former SFRY] who on 23 December 1990, the day the plebiscite on the independence of the Republic of Slovenia was held, were registered as permanent residents in the Republic of Slovenia and actually reside there shall, until they acquire citizenship of Slovenia under section 40 of the Citizenship of the Republic of Slovenia Act or until the expiry of the time-limit set forth in section 81 of the Aliens Act, have equal rights and duties to the citizens of the Republic of Slovenia...". See also Case Kurić and Others v Slovenia, Application No. 26828/06, 26 June 2012, para. 202.

${ }_{670}$ Case Kurić and Others v Slovenia, Application No. 26828/06, 26 June 2012, para. 207.

671 Case Kurić and Others v Slovenia, Application No. 26828/06, 26 June 2012, para. 202.

672 Case Kurić and Others v Slovenia, Application No. 26828/06, 26 June 2012, para. 28. 
applicants' names were erased from the Slovenian Register of Permanent Residents and they consequently became persons illegally residing in Slovenia, despite having previously possessed permanent resident status. Particularly noteworthy is the fact that one of these internal instructions stated that the personal documents of citizens of other SFRY Republics issued by the Slovenian administrative authorities should be kept and their passports revoked and destroyed. ${ }^{673}$ Paradoxically, nationals of States, other than former SFRY republics who were granted a permanent residence permit according to the pre-independence legislation, continued to enjoy that status upon independence and after the entry into force of the Aliens Act. ${ }^{674}$

According to the statistics provided in the Kurić decision, 200,000 Slovenian residents were former citizens of the SFRY (approximately 10\% of the Slovenian population). Of that figure, 171,132 applied for and were granted citizenship of the newly independent Slovenian State. However, 25,671 of them became "erased" persons and around 11,000 individuals left Slovenia. ${ }^{675}$ As pointed out by the Court,
"(...) the "erased" became aliens or stateless persons illegally residing in Slovenia. In general, they had difficulties in keeping their jobs and driving licences and obtaining retirement pensions. Nor were they able to leave the country, because they could not re-enter without valid documents. Many families became divided, with some of their members in Slovenia and others in one of the other successor States to the former SFRY. Among the "erased" were 5,360 minors. In most cases their identity papers were taken away. Some of the "erased" voluntarily left Slovenia. Some were served with removal orders and deported from Slovenia". ${ }^{676}$

A large number of nationals from the other republics of the former SFRY therefore found themselves living in Slovenia without a regulated status. In 1999, the situation of the "erased" was brought before the Slovenian Constitutional Court. ${ }^{677}$ The Court held that section 81 of the Aliens Act was unconstitutional as it had not set out the conditions for acquisition of permanent residence of the "erased" and left them in a less favourable position compared with other aliens who had lived in Slovenia before the date of independence. According to the Constitutional Court, the provisions

\footnotetext{
${ }_{673}$ Case Kurić and Others v Slovenia, Application No. 26828/06, 26 June 2012, para. 28.

674 Case Kurić and Others v Slovenia, Application No. 26828/06, 26 June 2012, para. 34.

${ }_{675}$ Case Kurić and Others v Slovenia, Application No. 26828/06, 26 June 2012, paras. 23, 26, 32 and 69.

676 Case Kurić and Others v Slovenia, Application No. 26828/06, 26 June 2012, para. 33.

677 Decision of the Slovenian Constitutional Court, 4 February 1999 (U-I-284/94).
} 
of the Aliens Act dealing with the acquisition of permanent and temporary residence for aliens entering Slovenia
"should not be used to regulate the status of citizens of the former SFRY republics who had a reasonable expectation that the new conditions for retaining permanent residence in Slovenia would not be stricter than those set forth in section 13 of the Constitutional Law ${ }^{678}$ and section 40 of the Citizenship Act, ${ }^{679}$ and that their status would be determined in accordance with international law" ${ }^{680}$

As a result of the judgment of the Constitutional Court, the Slovenian Government passed the Act on Regularisation of the Legal Status of Citizens of Other Successor States to the Former SFRY in Slovenia in 1999. ${ }^{681}$ The Act addressed the situation of the "erased" by simplifying the conditions to acquire a permanent residence permit. However, in 2003 the Constitutional Court found certain provisions of this Act to be unconstitutional. ${ }^{682}$ This was because the legislation did not grant permanent residence ex tunc (i.e. from the date of the "erasure"), and also due to the fact that it did not regulate the position of those who had been deported following the "erasure". The Act was further amended and in 2010 the Constitutional Court found the Act, as amended, to be constitutional. ${ }^{683}$

6781991 Constitutional Law relating to the Fundamental Constitutional Charter on the Sovereignty and Independence of the Republic of Slovenia (Ustavni zakon za izvedbo Temeljne ustavne listine o samostojnosti in neodvisnosti RS - Official Gazette of the RS no. 1/91-I of 1991), Section 13: "Citizens of the other republics [of the former SFRY] who on 23 December 1990, the day the plebiscite on the independence of the Republic of Slovenia was held, were registered as permanent residents in the Republic of Slovenia and actually reside there shall, until they acquire citizenship of Slovenia under section 40 of the Citizenship of the Republic of Slovenia Act or until the expiry of the time-limit set forth in section 81 of the Aliens Act, have equal rights and duties to the citizens of the Republic of Slovenia..." [footnote added GMG].

${ }^{679}$ Citizenship of the Republic of Slovenia Act (Zakon o državljanstvu Republike Slovenije, Official Gazette nos. 1/91-I, 30/91 and 96/2002 of 1991 and 2002), Section 40: "Citizens of another republic [of the former SFRY] who on 23 December 1990, the day the plebiscite on the independence of the Republic of Slovenia was held, were registered as permanent residents in the Republic of Slovenia and actually reside there shall acquire citizenship of the Republic of Slovenia if, within six months after the present Act enters into force, they submit an application to the internal affairs authority of the municipality where they live..." [Footnote added GMG].

${ }_{680}$ Case Kurić and Others v Slovenia, Application No. 26828/06, 26 June 2012, para. 45.

${ }^{681}$ Zakon o urejanju statusa državljanov drugih držav naslednic nekdanje SFRJ $v$ Republiki Sloveniji, Official Gazette, nos. 61/99 and 54/2000 of 1999 and 2000.

${ }_{682}$ Constitutional Court decision 3 April 2003, (U-I-246/02).

683 Case Kurić and Others v Slovenia, Application No. 26828/06, 26 June 2012, para. 73. 


\subsection{Proceedings before the Third Section}

In 2006 the applicants brought claims before the ECtHR for breaches of Articles 8, 13 and 14 of the ECHR. In its judgment of 3 March 2009, the Chamber (Third Section) held that some applicants' claims were inadmissible as the retroactive provision of permanent residence was an adequate and sufficient remedy, which meant that those applicants could no longer claim to be victims. As to the substantive complaints, the Chamber held that there was a violation of Articles 8 and 13 of the Convention. As regards Article 14, the Court concluded that, in view of its finding of a violation of Article 8, it was not necessary to rule on the applicants' complaint under that provision.

In reaching these conclusions, the Court began its analysis by reaffirming that, as a matter of international law and subject to its treaty obligations, a State is entitled to control the entry of aliens into its territory and their residence there:

"Nevertheless, the decisions taken by States in the immigration sphere can in some cases amount to interference with the right to respect for private and family life secured by Article $8 \S 1$ of the Convention, in particular where the persons concerned possess strong personal or family ties in the host country which are liable to be seriously affected by application of the measure in question. Such interference is in breach of Article 8 unless it is "in accordance with the law", pursues one or more legitimate aims under the second paragraph of that Article, and is "necessary in a democratic society" in order to achieve them". ${ }^{684}$

Article 8 of the Convention protects the right to establish and develop relationships with other human beings and the outside world

"and can sometimes embrace aspects of an individual's social identity. It must be accepted that the totality of social ties between settled migrants and the community in which they are living constitute part of the concept of private life within the meaning of Article 8".685

The Court considered from the outset that the expulsion of a settled migrant constitutes an interference with his or her right to respect for private life and family life. It will depend on the circumstances of the particular case

${ }^{684}$ Case Kurić and Others v Slovenia, Application No. 26828/06, 13 July 2010, para. 351.

${ }^{685}$ Case Kurić and Others v Slovenia, Application No. 26828/06, 13 July 2010, para. 352. 
whether focus must be placed on the family life rather than the private life aspect. In order to conclude that the applicants had a private and/or family life in Slovenia within the meaning of Article 8 of the ECHR, the Court took into account the fact that the applicants, before independence, had lived in the territory of the Republic of Slovenia for several years -most of them for decades- and all of them had lawful permanent residence in Slovenia under the applicable SFRY legislation at the material time. Furthermore, the applicants settled in Slovenia as SFRY citizens and registered their permanent residence in the same way as citizens of the then Socialist Republic of Slovenia, which give them "a stronger residence status than long-term migrants". ${ }^{686}$ In Slovenia, they developed a network of personal, social, cultural, linguistic and economic relations that make up the private life of every human and most of them also developed family life in Slovenia or maintained close ties with their family living in Slovenia. ${ }^{687}$

Thus, the failure to pass appropriate legislation and to regulate the status of the "erased" as already pointed out by the Slovenia Constitutional Court, constituted an interference with the exercise of the applicants' right to respect for their private and/or family life, especially when statelessness was the result. Furthermore, the Court considered that such interference was not justifiable.

As regards Article 13 of the ECHR, in light of the decisions issued by the Constitutional Court in Slovenia, the Court concluded that the "respondent Government have failed to establish that the remedies at the applicants' disposal can be regarded as effective remedies". Consequently, the Court found that there was also a violation of Article 13 of the ECHR.

\subsection{Proceedings before the Grand Chamber}

Pursuant to the Slovenian Government's request, in 2010 the case was referred to the Grand Chamber and a hearing was held in July 2011. The Slovenian Government reiterated before the Grand Chamber its objection that the applicants' complaints were incompatible ratione materiae and ratione temporis with the ECHR. According to the plea of the government, the ECHR does not regulate citizenship or residence and

${ }^{686}$ Case Kurić and Others v Slovenia, Application No. 26828/06, 13 July 2010, para. 357.

687 Case Kurić and Others v Slovenia, Application No. 26828/06, 13 July 2010, para. 359. 
"the entry into force of the independence legislation and the "erasure" took place in 1992, that is, before 28 June 1994, the date on which the Convention entered into force in respect of Slovenia".688

The Grand Chamber dismissed these objections and confirmed the assessment of the Third Section in this point. The Court held that it may examine the facts which

"had occurred prior to ratification inasmuch as they could be considered to have created a continuous situation extending beyond that date or might have been relevant for the understanding of facts occurring after that date. The repercussions of the "erasure", which had been found to be unconstitutional on 3 April 2003, had still obtained on 28 June 1994 and were continuing to adversely affect the applicants more than fifteen years after the entry into force of the Convention in respect of Slovenia". ${ }^{689}$

The Grand Chamber essentially reiterated the decision of the Chamber. In relation to the violation of Article 8 of the ECHR, as pointed out by Vidmar, the Court further emphasised "that the ECHR does not give a citizen of a party to the convention a right of residence in another state party". 690 However, given the connection between residence rights and the obligation to respect family life as provided in Article 8 of the ECHR, restrictions on the former may interfere, under certain circumstances, with the latter. ${ }^{691}$

"Upon achieving independence, Slovenia denied the continued right of residency to a number of citizens of other states emerging from the former SFRY who had, while the SFRY still existed, established their permanent residency in Slovenia". ${ }^{692}$

Regarding Article 14 of the ECHR, however, the Grand Chamber considered it necessary to rule on the applicants' complaint under that provision. The

${ }^{688}$ Case Kurić and Others v Slovenia, Application No. 26828/06, 26 June 2012, para 238.

689 Case Kurić and Others v Slovenia, Application No. 26828/06, 26 June 2012, para 240. See also Case Kurić and Others v Slovenia, Application No. 26828/06, 13 July 2010, paras. 303-315.

${ }^{690}$ Jure Vidmar, "The Scottish Independence Referendum in an International Context," Canadian Yearbook of International Law 51, 2013, p. 283 and Case Kurić and Others v Slovenia, Application No. 26828/06, 26 June 2012, para 355.

691 Jure Vidmar, "The Scottish Independence Referendum in an International Context," Canadian Yearbook of International Law 51, 2013, p. 283 and Case Kurić and Others v Slovenia, Application No. 26828/06, 26 June 2012, para 355.

${ }^{692}$ Jure Vidmar, "The Scottish Independence Referendum in an International Context," Canadian Yearbook of International Law 51, 2013, pp. 282-283. 
ECtHR concluded that there was a violation of Article 14 of the Convention taken in conjunction with Article 8.

The Court reasoned that the status of citizens of States other than the former SFRY republics who had lived in Slovenia before its independence was regulated by the Aliens Act (which provided that their permanent residence permits remained valid). However, the Aliens Act failed to regulate the status of the citizens of other SFRY republics who were resident in Slovenia, i.e. the so called "erased", who became illegal residents on the Slovenian territory. Thus, before independence

"there was a difference between these two groups, since one was composed of aliens, whereas the other was composed of citizens of the former federal State of which Slovenia was a constituent part. However, in the Court's opinion, after the declaration of independence and the coming into existence of the new State, their situation became at least comparable. The two groups were both composed of aliens holding citizenship of a State other than Slovenia or stateless people. As an effect of the "erasure", members of only one of the groups could keep their residence permits". ${ }^{693}$

For the Court, the difference in treatment between two groups was clear, and that differentiation could not be justified.

\section{Applying the Kurić Doctrine in a State Succession Scenario "within" the EU}

According to the ECtHR, withdrawing -upon independence- the right to permanent residence to the foreign citizens who, at the time of the former federation, established their permanent residency in Slovenia was, inter alia, a violation of the Convention right to private and family life. ${ }^{694}$ The connection between residence rights and the obligation to respect family life as provided in Article 8 of the ECHR is not alien to EU law. ${ }^{695}$ Article 7 of the Charter of Fundamental Rights of the EU, with a similar wording than Article 8 of the ECHR, regulates the right to private and family life. Even secondary EU legislation, for example, the preamble of the Directive on

${ }^{693}$ Case Kurić and Others v Slovenia, Application No. 26828/06, 26 June 2012, para 391.

${ }^{694}$ Case Kurić and Others v Slovenia, Application No. 26828/06, 26 June 2012, para. 337. See also Jure Vidmar, "The Scottish Independence Referendum in an International Context," Canadian Yearbook of International Law 51, 2013, pp. 282283.

695 Anja Wiesbrock, Legal Migration to the European Union: Ten Years After Tampere, Wolf Legal Publishers, Nijmegen, 2009, p. 199. 
the right to family reunification, ${ }^{696}$ which establishes the conditions for the exercise of the right to family reunification by TCNs residing lawfully in the territory of the Member States, ${ }^{697}$ expressly highlights its compliance with

"the obligation to protect the family and respect family life enshrined in many instruments of international law. This Directive respects the fundamental rights and observes the principles recognised in particular in Article 8 of the European Convention for the Protection of Human Rights (...)".

Similarly, it will come as no surprise that the Directive that lays down the conditions for EU citizens to exercise the right of permanent residence in the territory of the EU, but it also regulates the residence rights of their family members. ${ }^{699}$

As Vidmar noted regarding the Kurić case, the Court stressed "that the ECHR does not give a citizen of a party to the convention a right of residence in another state party". ${ }^{700}$ However, given the connection between residence rights and the obligation to respect family life as provided in Article 8 of the ECHR, restrictions on the former may interfere, under certain circumstances, with the latter. ${ }^{701}$ Thus, as was noted by the ECtHR,

"the applicants, who, prior to Slovenia's declaration of independence, had been lawfully residing in Slovenia for several years, had, as former SFRY citizens, enjoyed a wide range of social and political rights". ${ }^{702}$

${ }^{696}$ Council Directive 2003/86/EC of 22 September 2003 on the right to family reunification, OJ L (251), 03 October 2003.

${ }^{697}$ Council Directive 2003/86/EC of 22 September 2003 on the right to family reunification, OJ L (251), 03 October 2003, Article 1.

${ }^{698}$ Council Directive 2003/86/EC of 22 September 2003 on the right to family reunification, OJ L (251), 03 October 2003, Preamble, Recital 2.

699 Directive 2004/38/EC of the European Parliament and of the Council of 29 April 2004 on the right of citizens of the Union and their family members to move and reside freely within the territory of the Member States amending Regulation (EEC) No 1612/68 and repealing Directives 64/221/EEC, 68/360/EEC, 72/194/EEC, 73/148/EEC, 75/34/EEC, 75/35/EEC, 90/364/EEC, 90/365/EEC and 93/96/EEC.

700 Jure Vidmar, "The Scottish Independence Referendum in an International Context," Canadian Yearbook of International Law 51, 2013, p. 283 and Case Kurić and Others v Slovenia, Application No. 26828/06, 26 June 2012, para 355.

701 Jure Vidmar, "The Scottish Independence Referendum in an International Context," Canadian Yearbook of International Law 51, 2013, p. 283 and Case Kurić and Others v Slovenia, Application No. 26828/06, 26 June 2012, para 355.

702 Case Kurić and Others v Slovenia, Application No. 26828/06, 26 June 2012, para 356. See also Jure Vidmar, "The Scottish Independence Referendum in an International Context," Canadian Yearbook of International Law 51, 2013, p. 283. 
In the EU context, former EU citizens, residing in the territory of the $\mathrm{EU}$, who lose that status due to the enactment of nationality laws upon independence, may find themselves in a very similar situation. In this regard, the ECtHR declared that:

"an alien lawfully residing in a country may wish to continue living in that country without necessarily acquiring its citizenship. As shown by the difficulties faced by the applicants, for many years, in obtaining a valid residence permit, the Slovenian legislature failed to enact provisions aimed at permitting former SFRY citizens holding the citizenship of one of the other republics to regularise their residence status if they had chosen not to become Slovenian citizens or had failed to do so. Such provisions would not have undermined the legitimate aims of controlling the residence of aliens or creating a corpus of Slovenian citizens, or both". ${ }^{703}$

As concluded by Vidmar, the right of residence, once an individual has lawfully established residency on the territory of a particular State, is maintained, "even if the legal status of either your home or your host state changes, and, as a result of this change, your new citizenship status alone would no longer give you a right to residence". ${ }^{704}$ This conclusion is also supported by Article 20(1)(a) of the ECN, according to which a national of the predecessor State habitually resident in the territory of the successor State and who has not acquired its nationality, "shall have the right to remain in that State". The explanatory report to the $\mathrm{ECN}^{705}$ states that the aim of this provision is to ensure that States involved in the State succession enable non-nationals to be in a position "to lead the same life, from a practical day-today point of view, as before the State succession occurred". This article deals with the enjoyment of certain social and political rights by permanent residents. The link between the enjoyment of those rights, the residence status and the right to family life is salient from the wording of Recital 122 of the Explanatory Report:

"A necessary prerequisite in order to be able to enjoy social and economic rights is the right to remain within the territory of the successor State (...). This right is sometimes also described as a right of residence or the freedom of establishment. It should be recalled that such persons will normally have a right to family life under Article 8

703 Case Kurić and Others v Slovenia, Application No. 26828/06, 26 June 2012, para. 357.

704 Jure Vidmar, "The Scottish Independence Referendum in an International Context," Canadian Yearbook of International Law 51, 2013, p. 283.

705 Explanatory Report to the European Convention on Nationality, 6 November 1997, ETS 166. 
of the ECHR and, where this article applies, may not be expelled even if they are not considered to be nationals".

Regrettably, this provision only addresses the situation of nationals of the predecessor State residing in the territory of the successor State at the time the of State Succession. Nationals of States (other than the successor State) that were habitually resident on the territory of the successor State at the time of the State succession and were still resident there after the State succession, are not covered by this provision. In other words, in the EU context, TCNs and nationals of other EU Member States but the Member State involved in the eventual State Succession are excluded from the scope of Article 20, although the heading of this section (misleadingly) reads "Principles concerning non-nationals" under the chapter on State succession and nationality.

The important factor, as indicated by Vidmar, ${ }^{706}$ is that an individual had that right from the moment that the territorial change took place. "It is notable that the court established that non-citizen residents enjoy this guarantee under the ECHR's right to private and family". ${ }^{707}$ Vidmar also concluded that the exercise of this right is autonomous, ${ }^{708}$ that is, it is not contingent on, for example, a family relationship with a citizen of the host State, as was the case in Zhu and $\mathrm{Chen}^{709}$ or as provided in the family reunification schemes in certain EU law instruments. ${ }^{710}$

706 Jure Vidmar, “The Scottish Independence Referendum in an International Context," Canadian Yearbook of International Law 51, 2013, p. 283.

707 Jure Vidmar, "The Scottish Independence Referendum in an International Context," Canadian Yearbook of International Law 51, 2013, p. 283. See also Case Kurić and Others v Slovenia, Application No. 26828/06, 26 June 2012, paras. 355 - 359.

708 Jure Vidmar, "The Scottish Independence Referendum in an International Context," Canadian Yearbook of International Law 51, 2013, p. 283.

709 Case C-200/02, Zhu and Chen [2004] ECR I-09951.

710 See Council Directive 2003/86/EC of 22 September 2003 on the right to family reunification, OJ L (251), 03 October 2003; Council Directive 2003/109/EC of 25 November 2003 concerning the status of third-country nationals who are longterm residents, OJ (L 016), 23 January 2004; Council Directive 2005/71/EC of 12 October 2005 on a specific procedure for admitting third-country nationals for the purposes of scientific research, OJ L (289), 3 November 2005; Council Directive 2009/50/EC of 25 May 2009 on the conditions of entry and residence of thirdcountry nationals for the purposes of highly qualified employment, OJ L (155), 18 June 2009; and Directive 2004/38/EC of the European parliament and of the Council of 29 April 2004 on the right of citizens of the Union and their family members to move and reside freely within the territory of the Member States, OJ L (158), 30 April 2004. 
This doctrine, in the scenario of an eventual independence of a devolved part of an EU Member State, may be relevant for the following groups of people: ${ }^{711}$

(i) Potential future nationals of the new State residing in the predecessor EU Member State;

(ii) Potential future nationals of the new State residing in other EU Member States;

(iii) Nationals of the predecessor State living in the new State; and

(iv) Third country nationals residing in the newly independent State.

Following Vidmar's conclusion in the context of the Scottish independence referendum ${ }^{712}$ and based on the Kurić doctrine, it is possible to assume that "the identified categories of persons would retain their present residence rights". ${ }^{713}$ No matter if the person concerned does or does not reside in the EU territory upon independence, by virtue of the Kurić formula, his or her residence status will be frozen. ${ }^{714}$ Thus, one can conclude with Vidmar that, even if EU citizenship is lost, as a result of a State succession, the ECHR applies and "protects the right of residence of those lawfully residing in territories covered by EU law at the moment of independence". ${ }^{715}$

However, the future development of that status after independence -the "defrosting" of the residence status - will certainly be different if the residence has been frozen in the territory of an EU Member State or in the territory of the newly independent State. The Kurić formula "[...] would 'cement' the existing residence rights but would not extend the

711 Compare with the categorisation made by Vidmar in the context of the Scottish independence referendum, Jure Vidmar, "The Scottish Independence Referendum in an International Context," Canadian Yearbook of International Law 51, 2013, p. 284.

712 Jure Vidmar, "The Scottish Independence Referendum in an International Context," Canadian Yearbook of International Law 51, 2013, p. 284.

${ }^{713}$ Jure Vidmar, "The Scottish Independence Referendum in an International Context," Canadian Yearbook of International Law 51, 2013, p. 284.

714 Note that Vidmar first uses the expression "freeze" and "freezing" when referring to the retention of residence rights in the context of the Scottish independence referendum, Jure Vidmar, "The Scottish Independence Referendum in an International Context," Canadian Yearbook of International Law 51, 2013, pp. 282 and 284.

715 Jure Vidmar, "The Scottish Independence Referendum in an International Context," Canadian Yearbook of International Law 51, 2013, p. 284. 
applicability of EU law to the territories exiting the $E U^{\prime \prime}{ }^{716}$ In the following sections the situation of the different categories of persons identified above is addressed, although a distinction is made between those who are resident on the territory of the EU (i.e. potential future nationals of the new States residing in the predecessor EU Member State or in other EU Member States) and those who are not resident on the territory of the EU (i.e. nationals of the predecessor State living in the new State and third country nationals residing in the newly independent States).

\section{Right to Reside as a Non-EU Member State National in an EU Member State upon Independence}

The focus in this section is placed on the position of nationals of the potential newly independent States residing, at the moment of independence, in the territory of an EU Member State (not necessary the territory of the predecessor State) without holding the nationality of an EU Member State, and therefore without holding the status of an EU citizen. Stated differently, this section addresses the situation of former European citizens residing on the EU territory who held the nationality of the predecessor EU Member State and, after independence, lost that status due to the acquisition of the nationality of the newly independent State. ${ }^{717}$

From the outset, their residence rights will be protected by operation of the Kurić formula. ${ }^{718}$ However, as already pointed out, this protection will be territorially restricted: ${ }^{719}$ it only guarantees those rights attached to the residence status insofar as the person concerned does not move to the territory of another EU Member State. However, the right to reside on the territory of an EU Member State different from the one in which that residence was established at the moment of independence can be derived from another European citizen. If the former EU citizen and newly TCN is married, in a relationship or is a relative of an EU Member State national, ${ }^{720}$

716 Jure Vidmar, “The Scottish Independence Referendum in an International Context," Canadian Yearbook of International Law 51, 2013, p. 284.

717 Nationals of EU Member States and dual nationals holding the nationality of, at least, one EU Member State are excluded from this category.

718 See Jure Vidmar, "The Scottish Independence Referendum in an International Context," Canadian Yearbook of International Law 51, 2013, pp. 284-285.

719 See Jure Vidmar, "The Scottish Independence Referendum in an International Context," Canadian Yearbook of International Law 51, 2013, p. 284.

720 The terms "being married, in a relationship or relative" are used to encompass only the categories of family members as defined in Article 2(2) of the Directive 2004/38/EC of the European parliament and of the Council of 29 April 2004 on the right of citizens of the Union and their family members to move and reside freely within the territory of the Member States, OJ L (158), 30 April 2004: "family member means: (a) the spouse; (b) the partner with whom the Union citizen has contracted 
he or she could fall within the scope of the citizenship directive, ${ }^{721}$ which provides for residence rights when such a link exists. In such a case, however, the right of residence is dependent on the residence right of the EU citizen who has exercised his or her free movement rights. ${ }^{722}$

When such a family tie $\mathrm{e}^{723}$ does not exist or, when it exists but the European citizen has not moved to, or resided, in a Member State other than that of which he or she is a national, then the citizenship directive is not applicable. A question that needs to be addressed in this scenario is the applicability of the Council Directive concerning the status of third-country nationals who are long-term residents ${ }^{724}$ in such cases. From the outset, that Directive may be applicable to those to TCNs residing legally in the territory of an EU Member State ${ }^{725}$ so long as they do not fall within the excluded categories stipulated in paragraph 2 of Article $3 .^{726}$ The long-term resident status

a registered partnership, on the basis of the legislation of a Member State, if the legislation of the host Member State treats registered partnerships as equivalent to marriage and in accordance with the conditions laid down in the relevant legislation of the host Member State; (c) the direct descendants who are under the age of 21 or are dependants and those of the spouse or partner as defined in point (b); (d) the dependent direct relatives in the ascending line and those of the spouse or partner as defined in point (b)".

721 Directive 2004/38/EC of the European parliament and of the Council of 29 April 2004 on the right of citizens of the Union and their family members to move and reside freely within the territory of the Member States amending Regulation (EEC) No 1612/68 and repealing Directives 64/221/EEC, 68/360/EEC, 72/194/EEC, 73/148/EEC, 75/34/EEC, 75/35/EEC, 90/364/EEC, 90/365/EEC and 93/96/EEC, OJ L (158), 30 April 2004.

722 Article 3 of Directive 2004/38/EC: "This Directive shall apply to all Union citizens who move to or reside in a Member State other than that of which they are a national, and to their family members as defined in point 2 of Article 2 who accompany or join them".

723 The term "family tie" is used to encompass only the categories of family members as defined in Article 2(2) of the Directive 2004/38/EC of the European parliament and of the Council of 29 April 2004 on the right of citizens of the Union and their family members to move and reside freely within the territory of the Member States, OJ L (158), 30 April 2004.

${ }^{724}$ Council Directive 2003/109/EC of 25 November 2003 concerning the status of third-country nationals who are long-term residents, OJ L 016,23 January 2004, pp. $0044-0053$.

725 The United Kingdom, Ireland and Denmark are not bound by or subject to the application of this Directive (See Recitals 25 and 26 of the Preamble to Directive $2003 / 109 / E C$ ). Thus, any reference made in the context of this Directive to territory of the EU only encompasses the territorial scope of application of the Directive.

${ }^{726}$ Article 3(2) of the Directive 2003/109/EC: "This Directive does not apply to thirdcountry nationals who:(a) reside in order to pursue studies or vocational training; (b) are authorised to reside in a Member State on the basis of temporary protection or have applied for authorisation to reside on that basis and are awaiting a decision on 
can be granted to TCNs who have resided legally and continuously within the territory of the Member State "for five years immediately prior to the submission of the relevant application". ${ }^{727}$

It must therefore be asked whether the requirement of five years of legal and continuous residence can be fulfilled by a former European citizen who has been living on the territory of an EU Member State other than that of which he or she is a national. In the case of European citizens who have already acquired the right of permanent residence in the host Member State according to Chapter IV of the citizenship directive, the change of status (i.e. from EU citizen with right of permanent residence to TCN with a long-term residence permit) should be granted almost automatically. Both the citizenship directive and the TCNs long-term residents directive, refer to the same quantitative and qualitative requirements regarding the period of residence necessary to acquire that permanent residence or long-term residence status: five years (quantitative) of legal and continuous residence (qualitative). However, in the case of citizens of the Union, the acquisition of the permanent residence status is not subject to the conditions provided for in Article 5 of the TCNs long-term residents directive, i.e., that the TCN shall have
"stable and regular resources which are sufficient to maintain himself/herself and the members of his/her family, without recourse to the social assistance system of the Member State concerned" and "sickness insurance in respect of all risks normally covered for his/her own nationals in the Member State concerned". ${ }^{728}$

It is remarkable that these requirements are similar to the ones that an EU citizen must meet in order to acquire the right of residence on the territory of another Member State for a period of longer than three

their status; (c) are authorised to reside in a Member State on the basis of a subsidiary form of protection in accordance with international obligations, national legislation or the practice of the Member States or have applied for authorisation to reside on that basis and are awaiting a decision on their status; (d) are refugees or have applied for recognition as refugees and whose application has not yet given rise to a final decision;(e) reside solely on temporary grounds such as au pair or seasonal worker, or as workers posted by a service provider for the purposes of cross-border provision of services, or as cross-border providers of services or in cases where their residence permit has been formally limited;(f) enjoy a legal status governed by the Vienna Convention on Diplomatic Relations of 1961, the Vienna Convention on Consular Relations of 1963, the Convention of 1969 on Special Missions or the Vienna Convention on the Representation of States in their Relations with International Organisations of a Universal Character of 1975".

727 Article 4(1) of Directive 2003/109/EC.

${ }^{728}$ Article 5 of Directive 2003/109/EC. 
months and less than five years. ${ }^{729}$ In this sense, one can conclude that a citizen of the Union that acquired the right of permanent residence in the territory of an EU Member State - other than that of which he or she is a national- has already met the requirements to acquire a long-term residence permit as a TCN. The EU Member State of residence may, in these cases, assess whether the conditions laid down to grant such a permit are still met and whether to grant that status (almost) automatically.

A factor that could hinder the almost automatic nature of this solution is not the assessment itself - which is not only lawful but advisablebut the so-called "integration conditions". ${ }^{730}$ An additional -and optional ${ }^{731}$ - criterion that the former citizen of the Union and newly TCN may have to comply with are the so-called "integration conditions" laid down by the domestic legislation of the Member State. ${ }^{732}$ This requirement is not mentioned in the citizenship directive for nationals of EU Member States, but it is explicitly mentioned in the TCNs longterm residents directive. EU Member States may take into account this criterion not only in granting the long-term residence permit, but also in the cases in which the long-term resident wishes to reside in the territory of another Member State other than the Member State which

729 Article 7(1)(b) of Directive 2004/38/EC establishes that the European citizens shall have the right of residence on the territory of another Member State for a period of longer than three months if they, inter alia, "have sufficient resources for themselves and their family members not to become a burden on the social assistance system of the host Member State during their period of residence and have comprehensive sickness insurance cover in the host Member State".

730 Across the EU, different integration conditions to acquire the nationality of that State are required in the naturalisation procedure. Citizenship test are required, for instance, in Austria, Denmark, Estonia, Hungary or the Netherlands. Other countries, like Luxembourg, require the attendance of "citizenship courses". Command of the language or proficiency in the language is a condition for naturalisation, inter alia, in Bulgaria, Croatia, Czech Republic, Finland, France, Germany, Greece, Latvia, Lithuania, Luxemburg, Malta, the Netherlands, Poland, Portugal, Romania, Slovenia, Slovakia and the United Kingdom. In respect of Belgium, proficiency in the language of the country, adequate social integration or adequate participation in the local community are conditions for naturalisation. In Spain, an adequate social integration has to be proved in order to acquire Spanish nationality via naturalisation. In the United Kingdom: sufficient knowledge of the language of the country and about life in the United Kingdom is required. See further: the European Union Democracy Observatory on Citizenship (EUDO Citizenship) database on modes of acquisition of nationality, mode A06 (ordinary naturalisation), available at http://eudo-citizenship.eu.

731 The optional nature of the integration conditions is clear from the wording of Articles 5(2) and 15 (3) of Directive 2003/109/EC.

732 Article 5(2) of Directive 2003/109/EC. 
granted him or her the long-term residence status, according to Chapter III of the TCNs long-term residents directive. ${ }^{733}$

One of the advantages of the long-term residence permit is that it allows TCNs to reside in the territory of an EU Member State other than the one that granted the permit. In practice, this means that the former EU citizen that have lost that status due to the operation of the nationality legislation upon independence and is residing in the territory of an EU Member State can not only claim the protection of his or her residence status through application of the Kurić formula, but may also seek the almost automatic acquisition of a long-term residence permit. Even more importantly, he or she can exercise free movement rights and acquire the right to reside in the territory of another Member State other than the one which granted the long-term residence status in the first place. In this sense, it seems that there is shift from migration to mobility within the EU (intra-mobility), at least regarding TCNs with long-term residence permits. ${ }^{734}$

Regarding the situation of former nationals of the predecessor State, residing in the territory of that State, who, upon independence, lose that nationality and, therefore, their status as European citizens, by becoming nationals of the newly independent State and newly TCNs in the predecessor State, the situation is less clear. Before independence, their residence rights derived from their status as nationals of that State. Their residence rights, as previously stated, will be frozen by applying the Kurić formula, subject to the aforementioned limitations. These individuals, while they were nationals of the predecessor State, also enjoyed the status of citizens of the Union. However, their right to reside in the territory of that State did not derive from that latter status, but from their previous nationality. Since this is a purely internal situation, one may argue that the applicability of the TCNs long-term residents directive, although possible upon the change of status from national of the EU Member State to TCN, cannot amount to the almost automatic grant of the long-term residence permit to those who haven been residing in that territory for a period longer than five years. However, the fact that the right to reside in the territory of that Member State has resulted not from the operation of EU law but due to the fact that the person or persons concerned had the nationality of that Member State does not necessarily disqualify that period of residence as legal and continuous.

733 According to Article 15(3) of Directive 2003/109/EC the integration measures shall not apply if the TCNs concerned have already met this requirement when the long-term resident status was granted. However, in theses cases the Member State may stipulate that language courses have to be attended.

734 Compare Christina Boswell and Andrew Geddes, Migration and Mobility in the European Union, Palgrave Macmillan, Basingstoke, 2010. 
Thus, as long as, prior to the application, the TCN has resided legally and continuously within the territory of the EU Member State for a period of five years that condition would be deemed to be fulfilled. The legal ground under which that period of residence was granted, would be no obstacle in calculating the five year period referred to in the TCNs long-term residents directive, as all that matter is that the legal and continuous criteria are met. The situation of those former EU citizens and newly TCNs living in the territory of an EU Member State - either the predecessor State or another EU Member State- for period shorter than five years needs to be addressed. The Kurić formula would be also relevant to protect the residence rights and, generally speaking, that period of residence shorter than five years should be taken into account for an eventual and future application under the TCNs long-term residents directive. It may be possible to apply other directives - as transposed into domestic lawthat confer certain residence rights on TCNs based on shorter time periods. Following a chronological order and leaving aside the TCNs longterm residents directive, these are the Directives adopted on the basis of Chapter 2, Title V, Part three of the TFEU and dealing with the residence status of TCNs: ${ }^{735}$

735 Regulations and directives dealing with asylum include: Council Directive 2001/55/ EC of 20 July 2001 on minimum standards for giving temporary protection in the event of a mass influx of displaced persons and on measures promoting a balance of efforts between Member States in receiving such persons and bearing the consequences thereof [OJ L (212), 7 August 2001, pp. 12-23], Council Directive 2003/9/EC of 27 January 2003 laying down minimum standards for the reception of asylum seekers [OJ L (31), 6 February 2003, pp. 18-25], Council Directive 2004/83/EC of 29 April 2004 on minimum standards for the qualification and status of third country nationals or stateless persons as refugees or as persons who otherwise need international protection and the content of the protection granted [OJ L (304), 30 September 2004, pp. 12-23], Council Directive 2005/85/EC of 1 December 2005 on minimum standards on procedures in Member States for granting and withdrawing refugee status [OJ L (326), 13 December 2005, pp. 1334] and Council Regulation (EC) No 343/2003 of 18 February 2003 establishing the criteria and mechanisms for determining the Member State responsible for examining an asylum application lodged in one of the Member States by a thirdcountry national [OJ L (50), 25 February 2003, pp. 1-10] are not the object of this study, since the assessed situation do not fall within the scope of application of those pieces of legislation. Similarly, Directive 2008/115/EC of the European Parliament and of the Council of 16 December 2008 on common standards and procedures in Member States for returning illegally staying third-country nationals [OJ L (348), 24 December 2008, p. 98-107] is not analysed since it is applicable to "illegally staying" TCNs. Due to the operation of the Kurić doctrine as described, the residence within the EU of nationals of the newly independent States is deemed to be legal residence. 
- Directive on the right to family reunification; ${ }^{736}$

- Directive on the conditions of admission of TCNs for the purposes of studies, pupil exchange, unremunerated training or voluntary service; ${ }^{737}$

- Directive on the residence permit issued to TCNs who are victims of trafficking in human beings or who have been the subject of an action to facilitate illegal immigration, who cooperate with the competent authorities; ${ }^{738}$

- Directive on a specific procedure for admitting TCNs researcher, ${ }^{739}$

- Directive on the conditions of entry and residence of TCNs for the purposes of highly qualified employment (blue card directive) $;{ }^{740}$

- Directive providing for minimum standards on sanctions and measures against employers of illegally staying TCNs; ${ }^{741}$ and

- Directive on a single application procedure for a single permit for TCNs to reside and work in the territory of a Member State and on a common set of rights for third-country workers legally residing in a Member State. ${ }^{742}$

736 Council Directive 2003/86/EC of 22 September 2003 on the right to family reunification, OJ L (251), 3 October 2003, pp. 12-18.

737 Council Directive 2004/114/EC of 13 December 2004 on the conditions of admission of third-country nationals for the purposes of studies, pupil exchange, unremunerated training or voluntary service OJ L (375), 23 December 2004, pp. 12-18.

738 Council Directive 2004/81/EC of 29 April 2004 on the residence permit issued to third-country nationals who are victims of trafficking in human beings or who have been the subject of an action to facilitate illegal immigration, who cooperate with the competent authorities, OJ L (261), 6 August 2004, pp. 19-23.

739 Council Directive 2005/71/EC of 12 October 2005 on a specific procedure for admitting third-country nationals for the purposes of scientific research, OJ L (289), 3 November 2005, pp. 15-22.

740 Council Directive 2009/50/EC of 25 May 2009 on the conditions of entry and residence of third-country nationals for the purposes of highly qualified employment, OJ L (155), 18 June 2009, pp. 17-29.

741 Directive 2009/52/EC of the European Parliament and of the Council of 18 June 2009 providing for minimum standards on sanctions and measures against employers of illegally staying third-country nationals, OJ L (168), 30 June 2009, pp. 24-32.

742 Directive 2011/98/EU of the European Parliament and of the Council of 13 December 2011 on a single application procedure for a single permit for thirdcountry nationals to reside and work in the territory of a Member State and on a 
However, the fact that these directives address certain aspects of the situation of TCNs in the EU does not mean that one could apply them, as transposed in the domestic legislation, to the specific case of new TCNs. For instance, the directive on family reunification does not stricto sensu confer a residence right on former EU citizens and new TCNs living in the territory of an EU Member State but rather concerns the family members ${ }^{743}$ of TCNs already "residing lawfully" in the territory of the EU. Thus, this directive would not confer an autonomous residence right on former EU citizens and new TCNs. However, its application is possible regarding the family members of the new TCNs, serving as a basis for that "lawful residence" as laid down in the Kurić formula. Similarly, the Directive on the residence permit issued to TCNs who are victims of trafficking in human beings or who have been the subject of an action to facilitate illegal immigration, who cooperate with the competent authorities has a limited personal scope of application: TCNs who are or have been victims of offences related to the trafficking in human beings and reached the age majority. At the discretion of the EU Member States, the scope could be extended to TCNs who have been the subject of an action to facilitate illegal migration and also minors. Furthermore, Article 1 of the directive highlights the link between the intention to cooperate and the granting of a temporary residence permit, so the "protection" that this directive provides in terms of residence rights does not seem to be better than the protection provided for in the Kurić formula.

The same can be concluded regarding the application of the Directive providing for minimum standards on sanctions and measures against employers of illegally staying TCNs since it does not confer any residence rights to TCNs. It simply lays down minimum common standards on sanctions and measures against employers who employ illegally staying TCNs. The latter lays down a single application procedure.

Regarding the rest of the directives, it would not be impossible to strengthen the residence status already given by the operation of the Kurić formula through them, obviously, when certain requirements are met. These directives are not generally applied to TCNs but to certain categories of TCNS such as students, researchers or highly qualified workers.

common set of rights for third-country workers legally residing in a Member State OJ L (343), 23 December 2011, pp. 1-9.

743 The term "family member" is used to encompass only the categories defined in Article 4 of the Council Directive 2003/86/EC of 22 September 2003 on the right to family reunification, OJ L (251), 3 October 2003, pp. 12-18. 


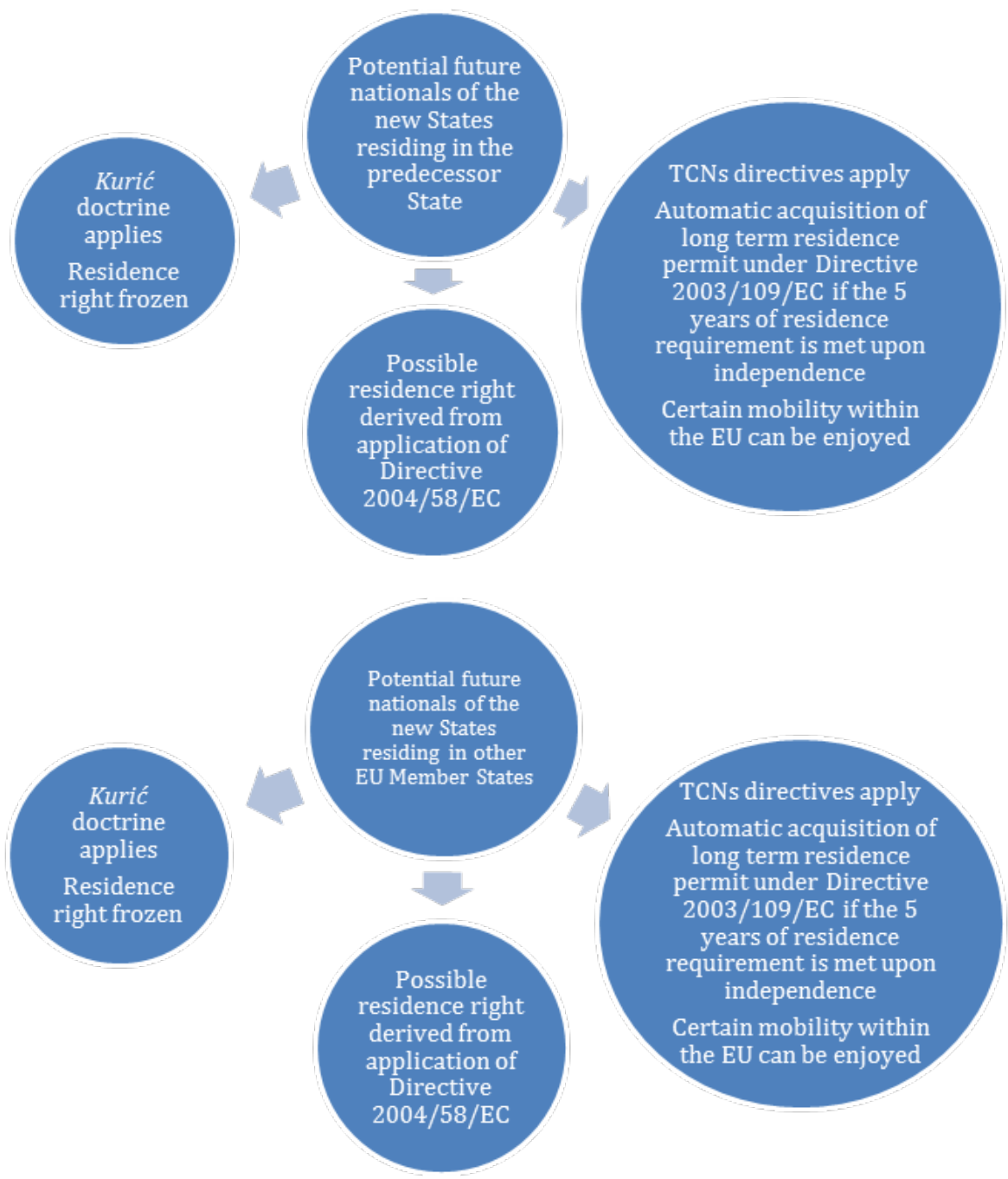

\subsection{The Specific Case of Former British nationals residing in the UK}

In accordance with Protocol (No 21) on the position of the United Kingdom and Ireland in respect of the area of freedom, security and justice annexed to the TEU and to the TFEU, the United Kingdom does not (automatically) take part in the adoption "by the Council of proposed measures pursuant to Title $V$ of Part Three of the Treaty on the Functioning of the European Union". ${ }^{74}$ Therefore, the United Kingdom is not bound by the Directives

744 Protocol (No 21) on the position of the United Kingdom and Ireland in respect of the area of freedom, security and justice. See Treaty on on the Functioning of the European Union (Consolidated Version) with Protocols, Annexes and Declarations 
that are adopted under that title of the TFEU. This does not mean that former Spanish, Belgian or British nationals who, upon independence, lose that nationality and acquire the nationality of the newly independent State lack any protection regarding their residence rights. The Kurić formula would be applicable, which would have the effect of freezing their existing residence rights. ${ }^{745}$ As already explained, even if EU citizenship is lost due to a changed legal status of a territory, the residence rights of those lawfully resident in the territories covered by EU law at the moment of independence will be protected by the ECHR. ${ }^{746}$
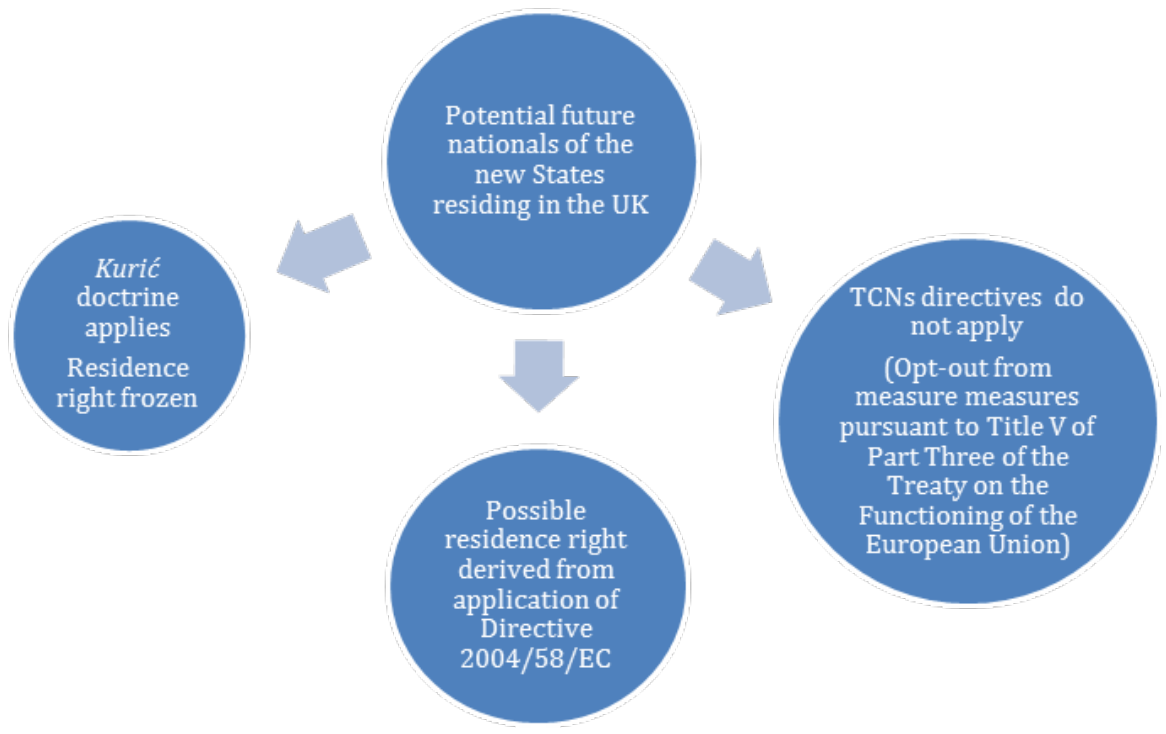

annexed to the Final Act of the Intergovernmental Conference which adopted the Treaty of Lisbon, 13 December 2007, OJ C (326), 26 October 2012. The United Kingdom and Ireland negotiated three opt-outs in the Treaty of Amsterdam in relation to the area of freedom, security and justice, these were: the Schengen acquis, border controls and measures adopted under the Title V of Part Three of the TFEU. The latter opt-outs mean in practice that the United Kingdom and Ireland are not bound by measures adopted under the mentioned title, but these two Member States have the option to take part in a proposed measure under that title or to choose to opt in after a measure under that title has been adopted. See Paul Craig and Gráinne de Búrca, EU Law. Text, cases, and materials, Oxford University Press (ed.), 6th edition, Oxford, 2015, pp. 977-979. For further analysis on the negotiations of the the United Kingdom and Ireland opt-outs see Steve Peers, "UK and Irish opt-outs from EU Justice and Home Affairs (JHA) law", 3 November 2009, available at http://www.statewatch.org/news/2009/nov/statewatch-analysislisbon-opt-outs-nov-2009.pdf.

745 Jure Vidmar, "The Scottish Independence Referendum in an International Context," Canadian Yearbook of International Law 51, 2013, p. 284.

746 Jure Vidmar, "The Scottish Independence Referendum in an International Context," Canadian Yearbook of International Law 51, 2013, p. 284. 
However, the eventual application of the directives on residence of TCNs would not be possible due to the fact that the United Kingdom opted out from measures pursuant to Title V, Part Three of the TFEU. The directive on the right of citizens of the Union and their family members to move and reside freely within the territory of the Member States is, nevertheless, applicable. This means that an eventual right to reside in the territory of an EU Member State, other than the one in which that residence was established at the moment of independence can be derived from another European citizen, if the requirements of the directive are met. However, that right of residence is dependent on an EU citizen who has exercised his or her free movement rights.

\section{Right to Reside in the Newly Independent States}

European citizens residing on the territory of the newly independent States upon independence would also benefit from the Kurić doctrine. ${ }^{747}$ The same, in principle, applies to TCNs. However, one has to remember that the territory of the newly independent States is not part of the EU territory. Thus, EU law would not apply within the borders of a Catalan, Flemish or Scottish State until it accedes to the EU. As pointed out by Vidmar, the Kurić formula '[...] would 'cement' the existing residence rights but would not extend the applicability of EU law to the territories exiting the $E U^{\prime \prime}{ }^{748}$ Therefore, the way in which the residence status is respected (and improved) depends solely on domestic law within the boundaries imposed by international law.

\subsection{Nationals of the Predecessor State and EU citizens residing in the Newly Independent State}

Nationals of the predecessor State and, generally, EU citizens residing in the newly independent State will become de facto foreigners. ${ }^{749}$ Not only due to a change of their personal status, but due to the State succession itself, this category of people, who may reside there on a permanent basis, would hold a status that gives them a set of rights within the territory of the EU (EU citizenship) and, more specifically, the territory of the State of their

747 Jure Vidmar, "The Scottish Independence Referendum in an International Context," Canadian Yearbook of International Law 51, 2013, pp. 284-285.

748 Jure Vidmar, "The Scottish Independence Referendum in an International Context," Canadian Yearbook of International Law 51, 2013, p. 284.

749 Notice the use of the term foreigners instead of TCNs. In the newly independent State, it makes no difference whether or not one is a EU citizen or a TCN within the meaning of EU law, since the territory of that State is non EU territory, it does not constitute part of the territory of the EU. 
nationality (nationality of the EU predecessor State). With the exception of the right to enjoy the protection of the diplomatic and consular authorities of any Member State with the conditions established in Article 20(2)(c) of the TFEU, no other right could be exercise by EU citizens on the territory of the newly independent State.

In this scenario, one can imagine that an ex lege withdrawal of the Spanish, Belgian or British nationality or the requirement to renounce to the previous nationality in order to acquire the Flemish, Catalan or Scottish nationality may lead to migration flows of nationals of the predecessor State to the territory of that predecessor State. For this reason, it is extremely important to guarantee a right of option. States involved in the succession should give consideration to the will of persons concerned, especially to nationals of the predecessor State. ${ }^{750}$

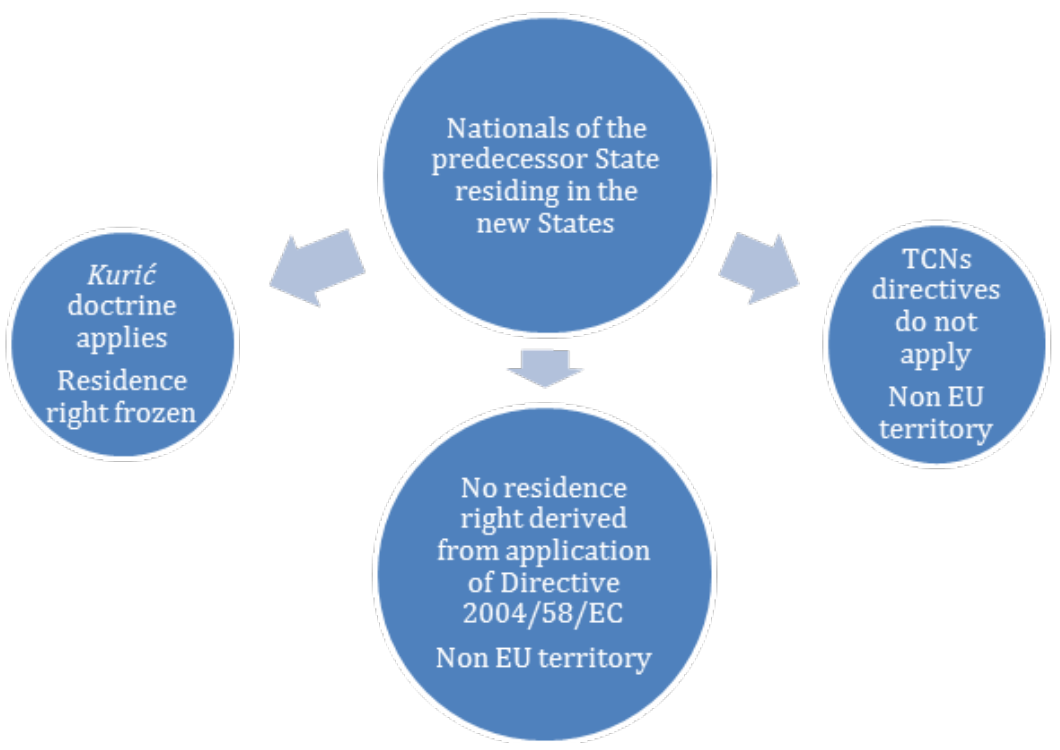

${ }^{750}$ See Chapter 2, section 4. 

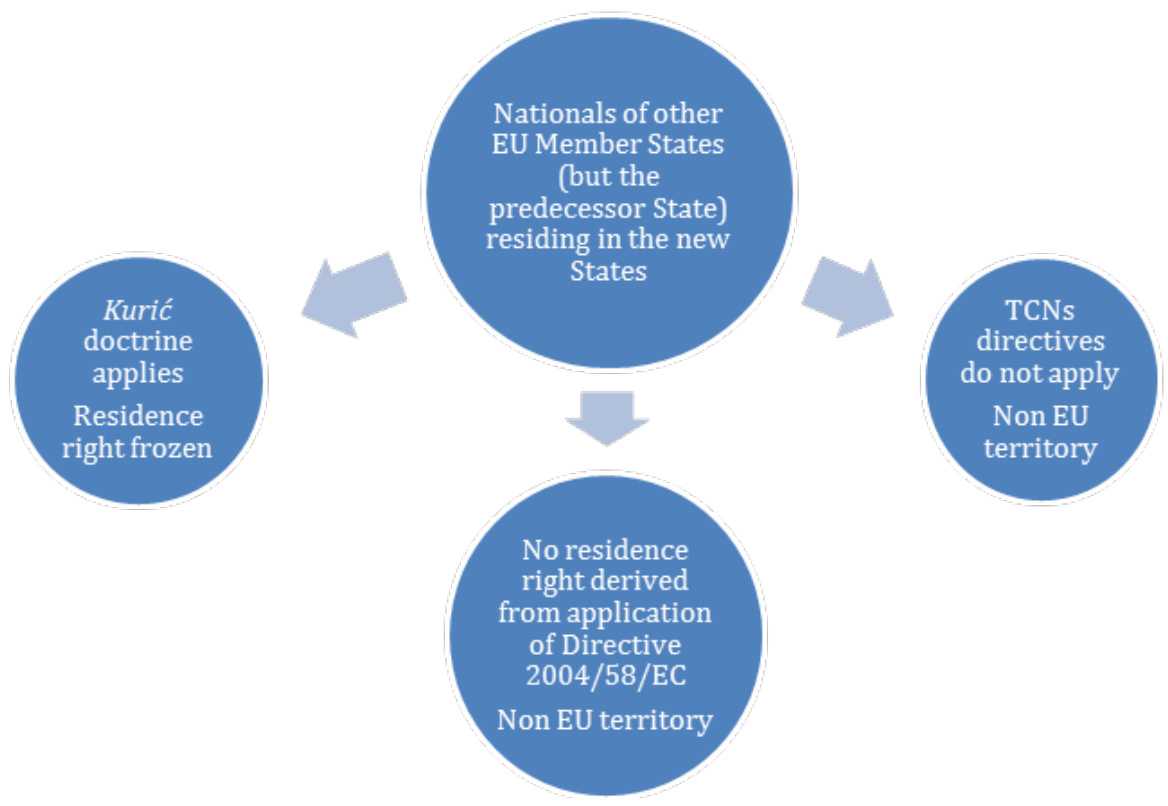

\subsection{TCNs residing in the Newly Independent State}

The non-application of EU law not only affects the rights of EU citizens, including the nationals of the predecessor State. A State succession in the EU would also affect the position of TCNs who, as explained in section 3, enjoy certain rights within the EU through the operation of EU law, as transposed by Member States.

In order to meet the requirement of five years of legal and continuous residence to acquire the long-term resident status, they cannot be absent from the territory of the predecessor EU Member State for any longer than six consecutive months. On the other hand, the acquisition of the nationality of the newly independent State is an option that may be offered to certain categories of TCNs; however this option fully depends on the first determination of nationals by the newly independent State and its policy towards granting nationality. 


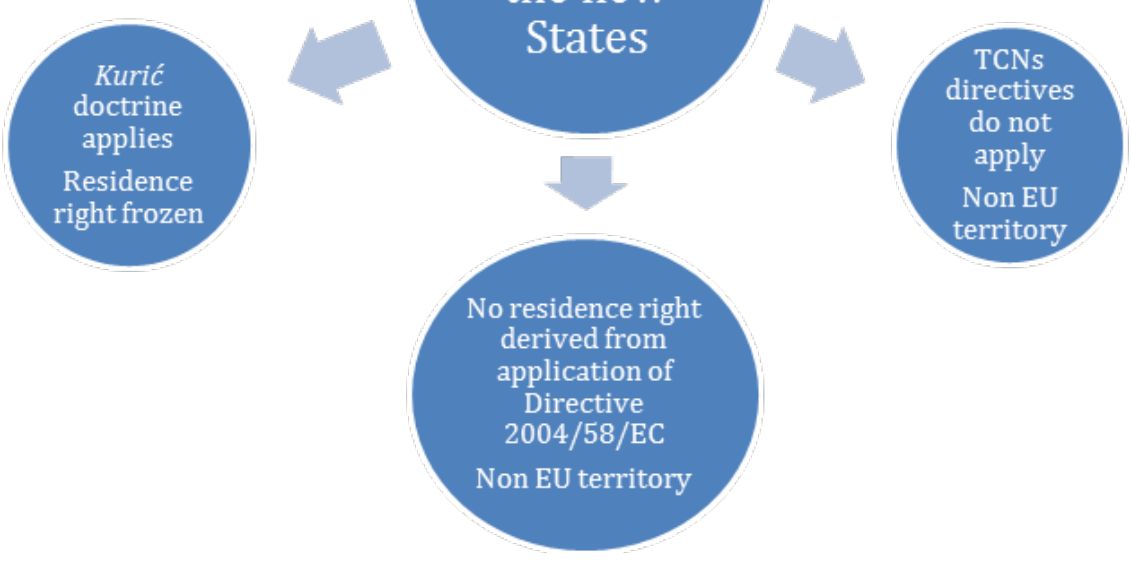

\section{Remarks on the Position of Minors}

As a result of a State succession, the nationality of the individuals involved in the State succession is prone to change. Chapter 2 analysed the rules and international legal standards for the operation of such a change in the nationality of the individuals concerned. In the case of State succession of a part of the territory of the EU, that change may also amount to the loss of the EU citizenship status. In some cases that change could take place ex lege due to the application of the nationality acts of the States involved, or in other cases by the choice of the person concerned. That change can also have consequences for the nationality status of minors. Surprisingly, there is no provision in either the 1999 ILC Draft Articles, or in the 2006 Council of Europe Convention that addresses the position of minors with regard to the change of nationality of his/her parent upon independence.

Rules on transmission of nationality from parents to children fall within the scope of domestic law, although some restrictions can be imposed by international law. ${ }^{751}$ Those rules may vary from one State to the next, following traditional patterns of transmission by ius sanguinis. ${ }^{752}$ The same

751 For instance, States may not regulate the transmission in a way that results in ethnic, racial or religious discrimination. See Article 5 ECN and Article 5 CERD.

752 See, for the way that States regulate this transmission, the EUDO-citizenship database mode A01A, A01B and A09. 
State autonomy in nationality matters also exists with regard the extension of the acquisition or loss of nationality by parents to their children. ${ }^{753}$ However, there is nothing to prevent international law from laying down minimum standards or guidelines addressing the specific situation of minors in respect of their change of nationality (or not) as a consequence of the change (or not) of nationality of the parent(s) in the context of a State succession scenario.

As pointed in the commentaries of the Draft Articles on Nationality of Natural Persons in relation to the Succession of States, the general policy after WWI was to ensure that all family members acquired the same nationality as the "head of the family" 754 and, in the case of minor children, the acquisition of the nationality of the head of the family was automatic. ${ }^{755}$ This kind of approach is now incompatible with the principle of equal treatment of men and women in the transmission of nationality to their children. ${ }^{756}$

The principle of family unity plays a role in this context. The best interests of the child and, inextricably linked to that, the will of the child, must be taken into account. ${ }^{757}$ According to the commentary on Article 7 of the Convention on the Avoidance of Statelessness in relation to State Succession, the will of a person to acquire the nationality of a specific State is usually expressed in the act of submitting an application for the acquisition of the nationality of that State. In the case of minors and other persons lacking full legal capacity, the minor's will may be expressed through their legal representative. However:

${ }^{753}$ For further information on how States regulate this extension, see: the EUDOcitizenship database mode A14.

${ }^{754}$ Commentary on Article 12 of the Draft Articles on Nationality of Natural Persons in Relation to State Succession, para. 1.

755 Compare Günter Breunig Staatsangehörigkeit und Entkolonisierung. Die Abgrenzung des Staatsvolkes bei der Verselbständigung der frankophonen Staaten Schwarzafrikas unter völkerrechtlichen Gesichtspunkten, Berlin: Duncker \& Humblot 1974, p. 201.

756 Article 9(2) of the 1979 Convention on the Elimination of All Forms of Discrimination against Women (CEDAW). See also: Gerard-René de Groot, Equal Treatment of Women and Men in Nationality Law, in: Ingrid Westendorp (ed.), The Women's Convention Turned 30: Achievements, Setbacks, and Prospects, Cambridge-AntwerpPortland: Intersentia 2012, pp. 185-200.

757 Recommendation CM/Rec (2009) 13 of the Committee of Ministers to Member States of the Council of Europe on the Nationality of Children. See also GerardRené de Groot, "Strengthening the position of children: Council of Europe's Recommendation (2009) 13", in: Erik Witjens, Viola Van Bogaert, Carlos Bollen (eds.), E Hofi di Ley, The Hague, 2014, pp. 483-484. 
"Where the child is old enough to be consulted his or her free will should be taken into account in conformity with the principle of the best interests of the child as stipulated in the 1989 United Nations Convention on the Rights of the Child". ${ }^{758}$

The right of the child to be heard in relation to the acquisition or loss of nationality is also highlighted in Recommendation CM/Rec (2009) 13 of the Committee of Ministers to Member States on the Nationality of Children (hereinafter, Rec 2009/13). Principle 19 thereof endeavours to

"ensure that, as far as possible, in proceedings affecting their nationality, children are consulted and their views and wishes are taken into account, having regard to their degree of maturity. Applications for nationality made on behalf of children should include the opinion of children considered by law as having sufficient understanding. A child should be considered as having sufficient understanding upon attaining an age, prescribed by law, which should not be more than 14 years". ${ }^{759}$

The explanatory memorandum to Rec 2009/13 also underpins the importance of taking into account the will of any children in proceedings affecting their nationality:

"Respect for the independent personality of the child and taking account of his or her views and wishes could imply restrictions on the parents' rights to speak for their children in nationality matters. In particular, rules have to be designed in order to increase the relative weight assigned to the will of the child in the form of the right to be heard and the right to give her or his opinion. The non-observation of the right of the child to be heard in cases of acquisition and loss of nationality can - under certain circumstances - violate Articles 8 and 12 of the United Nations Convention on the Rights of the Child. If a child is considered by law as having sufficient understanding, her or his nationality should not be decided without taking into account her or his opinion".760

758 Explanatory report on Article 7 of the 2006 Convention on the avoidance of Statelessness in relation to State Succession, para. 31.

759 Recommendation CM/Rec (2009) 13 of the Committee of Ministers to Member States of the Council of Europe on the Nationality of Children, principle V, para. 19.

760 Explanatory memorandum to the Recommendation CM/Rec (2009) 13 of the Committee of Ministers to Member States of the Council of Europe on the Nationality of Children, para. 49. 
This approach should be followed by both the successor State, as well as the predecessor State while regulating the nationality consequences of State succession for minors.

Furthermore, since minors above 16 years old were allowed to vote in the Scottish independence referendum and were also allowed to cast their votes in the Catalan independence query, their will regarding the acquisition (or not) of a certain nationality must be taken into account. It would unreasonable if a 16-year-old person who voted against the independence acquires the nationality of newly independent State as a consequence of change of nationality her/his parent(s) due to the operation of the laws on the extension of the acquisition nationality and lose the nationality of the predecessor State. As pointed out by the explanatory memorandum to Rec $2009 / 13$, the right of children to be heard is "of particular importance" in cases of extension of the naturalisation or extension of the loss of nationality of parent(s) to the child. ${ }^{762}$

Paradoxically, according to the explanatory memorandum, that right to be heard "only applies in case of nationality procedures and not in cases where a child acquires or loses a nationality ex lege". ${ }^{763}$ In a State succession scenario in which the nationality of newly independent State is automatically granted ex lege to nationals of the predecessor State when certain criteria are met (e.g. being habitually resident in the territory of the new State), that nationality will automatically be extended from parent(s) to children ex lege. ${ }^{764}$ According to the explanatory memorandum to Rec 2009/13, in that case, the right of children to be heard will not apply. This would mean that minors have no right to be heard in all cases of acquisition or loss of nationality due to the ex lege application of rules on extension of the nationality from parent(s) to children in the context of State succession. This conclusion is unacceptable from the perspective of minors who may acquire or lose a nationality without being heard, even contrary to their

761 Explanatory memorandum to the Recommendation CM/Rec (2009) 13 of the Committee of Ministers to Member States of the Council of Europe on the Nationality of Children, para. 50.

762 Gerard-René de Groot, "Strengthening the position of children: Council of Europe's Recommendation (2009) 13", in: Erik Witjens, Viola Van Bogaert, Carlos Bollen (eds.), E Hofi di Ley, The Hague, 2014, p. 483.

763 Explanatory memorandum to the Recommendation CM/Rec (2009) 13 of the Committee of Ministers to Member States of the Council of Europe on the Nationality of Children, para. 51.

764 Also according to the general rules on extension of nationality outside the State succession context, extension of acquisition of nationality happens in most cases ex lege. See: EUDO citizenship database, mode A14. Compare also extension of loss, EUDO citizenship database, mode L1. 
opinions or views on the independence process itself as expressed, for instance, in a referendum.

This conclusion is all the more incomprehensible in light of the fact that in most cases the acquisition or loss of nationality for nationals of the predecessor State residing on a permanent basis in the territory of the newly independent State will be ex lege and automatic as too will the extension of the acquisition or loss from parent(s) to children will be also automatic (ex lege). It is striking that no explanation is provided in Rec $2009 / 13$ or its explanatory memorandum to justify such a difference in approach between cases of "nationality procedures" and ex lege acquisition or loss of nationality. It seems that the position of minors in respect of the change of nationality of her/his parent(s) upon independence was not envisaged by the drafters of Rec 2009/13. However, this seems to also be the case for the 1996 Venice Declaration, the 1997 ECN, the 1999 ILC Draft Articles, and the 2006 Convention on Statelessness.

Despite the absence of any international legal instrument addressing this specific situation, it would be highly recommendable to provide for a mechanism to assure that the will of minors is taken into account. Preferably, an autonomous option right should be given to minors or, at the very least, the option to change of their nationality upon achieving the age of majority. An autonomous option right for minors is of paramount importance when one considers that the extension of the nationality from the parent(s) to the child implies the loss of the nationality of the predecessor State. In these cases, the decision on the nationality status of the child should be made autonomously and independently from the decision regarding the nationality of the parent(s). Special weight should be attached to the vulnerability of the person concerned, in this case, a minor. The latter option is also highlighted in Rec 2009/13. Principle 22 thereof provides that a minor who has lost their nationality during their minority due to the acts of their legal representative "or due to an extension of the loss of this nationality by a parent" ${ }^{\prime \prime 65}$ should be given the right to apply for the recovery of the nationality concerned within a certain period of time not shorter than three years after having reached the age of majority. This principle goes even further and recommends the right of minors to apply for recovery of the lost nationality before having reached that age when represented by a legal representative or a guardian ad litem. ${ }^{766}$

765 Explanatory memorandum to the Recommendation CM/Rec (2009) 13 of the Committee of Ministers to Member States of the Council of Europe on the Nationality of Children, para. 56. See also Gerard-René de Groot, "Strengthening the position of children: Council of Europe's Recommendation (2009) 13", in: Erik Witjens, Viola Van Bogaert, Carlos Bollen (eds.), E Hofi di Ley, The Hague, 2014, p. 484.

766 Recommendation CM/Rec (2009) 13 of the Committee of Ministers to Member 
In any case, the will of the minor should be taken into account. The absence of any international rules addressing the change on nationality status of minors in State succession scenarios, although surprising, may reflect the complexity of that situation. However, that should not be an obstacle to providing safeguards in order to avoid undesirable results, especially in the case of minors.

\section{Concluding Remarks}

One of the main features attached to the nationality status is the right of residence in the territory of that State. Thus, Spanish nationals currently residing in Catalonia enjoy that right as Spanish nationals living in Spanish territory. A similar observation can be made for British nationals residing in Scotland or Belgian nationals residing in Flanders. Within the EU, the right of residence of EU citizens in other EU Member States is conferred on all individuals who possess the status of citizen of the Union, which is linked to the possession of an EU Member State's nationality. Thus, one can argue that residence of EU citizens in other EU Member States other than the State of their nationality, ultimately derives from their domestic nationality status.

As explained in previous chapters, in a State succession scenario of a devolved part of an EU Member State, the nationality status of certain nationals of the predecessor EU Member State is likely to be affected by the independence. The switch from the nationality of the predecessor EU Member State to the nationality of the successor non-EU Member State also implies a change of the set of rights were previously enjoyed. Amongst them, the right to reside on a certain territory, i.e. the territory of the predecessor State, the successor State or other EU Member State not directly involved in the State Succession could become legally uncertain in a State succession scenario. However, it is worth noting that the nationality of the predecessor State served as the legal entitlement to reside in the territory of the predecessor State and the successor State, while the citizenship of the Union served as the legal entitlement to reside in other EU Member State -although, it must be reiterated that this latter status is linked to the nationality of the predecessor EU Member State. Despite the possible loss of the nationality of the predecessor EU Member State and, therefore, the EU citizenship status, it has been argued in this chapter that

States of the Council of Europe on the Nationality of Children, principle V, para. 22. Compare Article 6 Agreement between the Kingdom of the Netherlands and the Republic of Suriname concerning the assignment of nationality (Toescheidingsovereenkomst inzake nationaliteiten tussen het Koninkrijk der Nederlanden en de Republiek Suriname), 25 November 1975, UNTS vol. 997, no. 14598. 
residence rights, or stated differently, the right to reside permanently can be retained, as concluded by Vidmar, ${ }^{767}$ by operation of the Kurić formula.

Regardless of the entitlement, residence rights are linked to the obligation to respect private and family life as provided in Article 8 of the ECHR and Article 7 of the Charter of Fundamental Rights of the EU. This link has been also acknowledged at EU level, for instance in the Directive on the right to family reunification, or, indirectly, by the Directive that lays down the conditions to exercise the right of permanent residence in the territory of the EU by citizens of the Union which also regulates the right of residence of their family members.

How did the ECtHR reason in the Kurić case? As noted in previous sections, the ECtHR is clear when stating that the ECHR does not give a citizen of a State party to the Convention a right of residence on the territory of another State party. ${ }^{768}$ However, limitations on residence rights, "in certain cases", ${ }^{769}$ may "entail a violation of ${ }^{\prime 770}$ the Convention right to private and family life as enshrined in Article 8 ECHR. Thus, as noted by the Court and recalled by Vidmar, ${ }^{771}$

"the applicants, who, prior to Slovenia's declaration of independence, had been lawfully residing in Slovenia for several years, had, as former SFRY citizens, enjoyed a wide range of social and political rights". ${ }^{772}$

Former EU citizens, residing in the territory of the EU, who lost that status due to the enactment of nationality laws upon independence, may find themselves in a very similar position. The reasoning of the Court is relevant not only for protecting the residence status of former EU citizens, but also for EU citizens residing in the territory of the newly independent State and also for TCNs also residing on that territory.

767 Jure Vidmar, "The Scottish Independence Referendum in an International Context," Canadian Yearbook of International Law 51, 2013, pp. 283-285

768 Jure Vidmar, "The Scottish Independence Referendum in an International Context," Canadian Yearbook of International Law 51, 2013, p. 283 and Case Kurić and Others v Slovenia, Application No. 26828/06, 26 June 2012, para 355.

769 Case Kurić and Others v Slovenia, Application No. 26828/06, 26 June 2012, para 355.

770 Case Kurić and Others v Slovenia, Application No. 26828/06, 26 June 2012, para 355.

771 Jure Vidmar, "The Scottish Independence Referendum in an International Context," Canadian Yearbook of International Law 51, 2013, p. 283.

772 Case Kurić and Others v Slovenia, Application No. 26828/06, 26 June 2012, para 356. 
As pointed out by Vidmar and according to the Kurić decision, the right of residence, once that residency has been lawfully established, will be kept regardless of the changes on the "legal status of either [the] home or [the] host state", ${ }^{773}$ even when as a consequence of that change the new nationality "status alone would no longer give you a right to residence". ${ }^{74}$ Thus, as a result of the application of the Kurić formula, it is possible to conclude with $\operatorname{Vidmar}^{775}$ that the residence status of the groups of people indicated in table No. 5 will be frozen. The key element is that the residence status has to be enjoyed in the moment directly prior to independence. ${ }^{776}$ The frozen residence status is not dependent on or derived from family ties, it is an autonomous right under Article 8 of the ECHR. ${ }^{777}$ Regardless of whether or not the person concerned resides on EU territory upon independence and even if EU citizenship is lost due to the State succession, the residence status will be frozen. ${ }^{778}$ The protection of the residence status given by the Kuric formula is, however, restricted territorially: ${ }^{779}$ it only guarantees those rights attached to the residence status as far as the person concerned does not move to another country. It therefore seems more appropriate, following Vidmar's idiolect, ${ }^{780}$ to talk about a territorially frozen residence status when applying the reasoning of the ECtHR in the Kurić case.

However, former EU citizens residing on the territory of the EU may additionally benefit from the TCN's long-term residence directive and on that basis enjoy certain free movement rights within the Union. In that regard it makes a difference whether or not a person is residing on EU territory. None of the categories of people residing in the territory of the successor non-EU Member State can benefit from the application of EU law to improve their residence status and enjoy certain mobility rights within the EU. Furthermore, due to the opt-out of the United Kingdom from the Title V, Part Three of the TFEU, the TCNs directive cannot be applied to

773 Jure Vidmar, "The Scottish Independence Referendum in an International Context," Canadian Yearbook of International Law 51, 2013, p. 283.

774 Jure Vidmar, "The Scottish Independence Referendum in an International Context," Canadian Yearbook of International Law 51, 2013, p. 283.

775 Jure Vidmar, "The Scottish Independence Referendum in an International Context," Canadian Yearbook of International Law 51, 2013, p. 284.

776 See Jure Vidmar, "The Scottish Independence Referendum in an International Context," Canadian Yearbook of International Law 51, 2013, p. 283.

777 See Jure Vidmar, "The Scottish Independence Referendum in an International Context," Canadian Yearbook of International Law 51, 2013, p. 283.

778 See Jure Vidmar, "The Scottish Independence Referendum in an International Context," Canadian Yearbook of International Law 51, 2013, p. 284.

779 See Jure Vidmar, "The Scottish Independence Referendum in an International Context," Canadian Yearbook of International Law 51, 2013, p. 284.

780 See Jure Vidmar, "The Scottish Independence Referendum in an International Context," Canadian Yearbook of International Law 51, 2013, pp. 282 and 284 
former EU citizens residing in that territory. Thus, an almost automatic application TCNs long-term residents directive to former EU citizens residing in the territory of the $\mathrm{EU}$ - as proposed in this chapter- is not possible when that residence is established in the United Kingdom.

It is appropriate to highlight that the findings in the previous paragraphs are also highly relevant for British citizens living in the EU post-"Brexit" and EU citizens residing in the United Kingdom post-"Brexit". In both cases, the Kurić formula will apply, protecting the residence rights of both British citizens residing outside the United Kingdom (but within the EU) who do not possess the nationality of an EU Member State and citizens of the Union residing in the United Kingdom. Although the facts in the Kuric decision and the "Brexit" situation may differ, the overall premise is the same: if residency has been lawfully established prior to "Brexit", when the United Kingdom proceeds with the withdrawal from the EU, ${ }^{781}$ that right of residence will be retained, even if the nationality "status alone would no longer give" 782 a right to residence in the United Kingdom for citizens of the Union or in the EU for British citizens. Furthermore, since no question related to statehood will arise in the context of "Brexit" (with the exception, perhaps, of an eventual independence of Scotland triggered by the withdrawal of the United Kingdom from the EU), there would be no obstacle in applying Article 8 of the ECHR, since the United Kingdom and all EU Member States are bound by that convention.

Another possible option that would allow certain mobility within the EU is deriving residence rights from another European citizen. If the former EU citizen and newly TCN is married, in a relationship or is a relative of an EU Member State national, ${ }^{783}$ he or she could fall within the scope of the citizenship directive (which is also applicable in the United Kingdom), which provides for residence rights when such a link exists. In such a case, the right of residence is, however, dependent on the residence right of the EU citizen who has exercised his or her free movement rights.

In this chapter, particular attention has been paid to the nationality position of minors. Traditionally minors acquired, in the State succession context, the nationality position of the head of the family, usually the nationality of the father. This approach has changed with the implementation of the principle of equal treatment of men and women in nationality law. Thus, in a State succession scenario, both the successor State and the predecessor

781 At the time of writing, the United Kingdom's intention to withdraw from the European Union was just notified to the European Council.

782 Jure Vidmar, "The Scottish Independence Referendum in an International Context," Canadian Yearbook of International Law 51, 2013, p. 283.

${ }^{783}$ See footnote 720. 
State have to regulate the nationality position of minors whose parents, due to operation of the nationality law enacted upon independence, have different nationalities. This issue becomes particular important since minors who reached the age of 16 years were enfranchised in the Catalan and Scottish independence queries. If the will of the minor is taken into account during the process of independence, it seems reasonable that it would also be taken into account regarding the acquisition or not of a certain nationality upon independence. In this line, one cannot accept the approach stipulated in Rec 2009/13 of the Committee of Ministers of the Council of Europe, according to which the right of minors to be heard is only applicable within the framework of nationality procedures but not in cases where the minor acquires or loses a nationality ex lege. In other words, minors would have no right to be heard in all cases of acquisition or loss of nationality due to the ex lege application of rules on extension of the nationality from parent(s) to children in the context of State succession. This conclusion is unacceptable and, despite the absence of any international legal instrument addressing this specific situation, it would be highly recommendable to provide for a mechanism to ensure that the will of minors is taken into account. 
Chapter 5: State Succession and the Right to Reside Permanently

Table No. 5

\begin{tabular}{|c|c|c|c|c|c|c|c|}
\hline & & \multicolumn{3}{|c|}{ EU territory } & \multicolumn{3}{|c|}{ Non EU territory } \\
\hline \multirow{2}{*}{ 离 } & 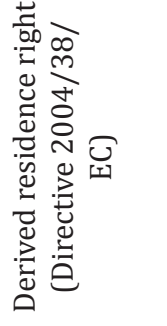 & $>$ & $>$ & $>$ & $x$ & $x$ & $x$ \\
\hline & 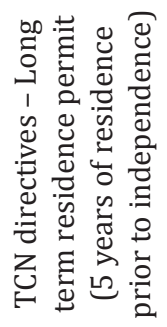 & $>$ & $x$ & $>$ & $x$ & $x$ & $x$ \\
\hline 号 & 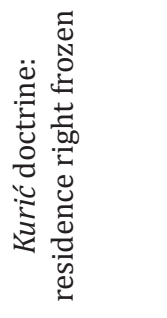 & $>$ & $>$ & $>$ & $>$ & $>$ & $>$ \\
\hline & & 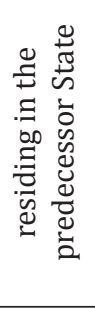 & 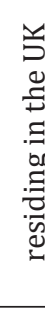 & 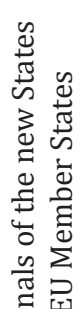 & 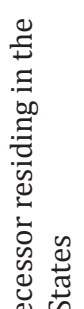 & 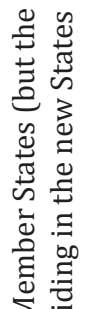 & 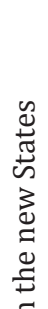 \\
\hline & & 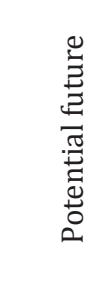 & & 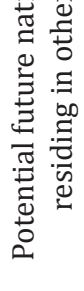 & 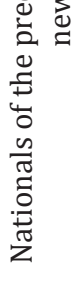 & 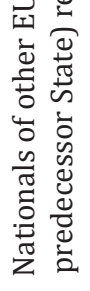 & 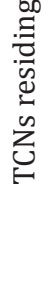 \\
\hline
\end{tabular}





\section{Chapter 6: Conclusions}

If Catalonia, Scotland or Flanders were to become independent, then this would undoubtedly be a unique event. This uniqueness is demonstrated by the fact that it would be the first case of the break-up of an EU Member State. And furthermore, the effects of the hypothetical independence of a devolved part of an EU Member State on the nationality of persons and their status as citizens of the Union raises novel legal issues, which cannot be addressed from the perspective of one legal order.

From a Public International Law perspective, a Catalan, Scottish or Flemish independence would amount to a case of State succession, i.e., the replacement of Spain, Belgium or the United Kingdom by the newly independent States in the responsibility for the international relations of those territories. ${ }^{784}$ Within the framework of Public International Law, questions related, inter alia, to the right to self-determination, the rules applicable to nationality matters arising in a State succession context and membership of international organisations need to be assessed. However, Public International Law is not holistic enough to provide answers to the challenges posed by a hypothetical independence of a devolved part of an EU Member State. Nationality matters arising in this context are far from simple and, given the link between nationality and EU citizenship, the picture becomes more complicated.

In the context of State succession, the new State has to determine who its nationals will be. The predecessor State must decide whether or not the acquisition of the nationality of the newly independent State will entail the loss of the nationality of the predecessor State. This "mathematical formula" becomes more complicated when the EU dimension is introduced. The link between the nationality of the predecessor State and citizenship of the Union adds a European element to the "formula". Moreover, historical experiences have shown that when a newly independent State enacts rules on the acquisition of nationality of the newly independent State, and the subsequent loss of the nationality of the predecessor State, then they must act in such a way that avoids not only statelessness, but also unnecessary migration flows. The examples of Suriname ${ }^{785}$ and the dissolution of the Socialist Federal Republic of Yugoslavia, as explained in Kurić and others

\footnotetext{
${ }^{784}$ See Chapter 2, section 1.

785 See footnote 86.
} 
$v$ Slovenia, ${ }^{786}$ are examples of migrations flows directly linked to a State succession situation and the application of nationality rules in that context. If such a situation takes place within the EU, migration flows can be triggered not only due to the application of nationality rules by both the predecessor and successor State, but also due to the willingness of the people to guarantee and secure certain rights under EU law.

At the heart of this "mathematical formula" are the people affected by the eventual independence of the regions at stake. These people, by operation of the hypothetical State succession, could witness a change of their status as nationals of an EU Member State and, therefore, citizens of the Union or, more generally, a change of the legal framework applicable to the territory where they have been residing under the umbrella of EU law. They could find themselves in a position where strategic decisions have to be made in order to retain a certain status under EU law or in order to guarantee the continuation of certain residence rights. It was the main aim of this thesis to explain how independence processes could affect these people, with emphasis on their nationality and residence status, and to assess the role that EU law can play in this scenario as a completely new factor in the State succession "mathematical formula". In addressing this issue, the following questions needed to be answered:

- Would the citizens of Catalonia, Flanders or Scotland cease to enjoy citizenship of the Union status if these devolved regions became independent States?

- What would be the situation of those EU citizens from other Member States residing in the potential new States?

- What would be the status of the citizens of the potential new States residing in an EU Member State?

- To what extent would EU law and the case law of the CJEU influence the nationality legislation of the potential new State?

- What would be the influence of EU Law on the reaction of the remaining Member States regarding its nationality policy?

- What about the situation of third country nationals residing in the potential new States, in particular those who possess long-term resident status?

786 See Chapter 5, section 1.1. 
As stated above, in order to provide answers to these questions it is necessary to adopt a multidimensional approach, taking into account three different yet intertwined legal orders: Public International Law, national law and EU law. In doing so, the first step taken was the analysis of the State succession as a general institution of Public International Law with special focus on rules applicable to nationality matters arising in that scenario. The work of the ILC and the Council of Europe on this issue proves not only the inherent complexity of this topic but also the reluctance of the States for further and more meaningful codification in this area.

Defining who the nationals of a certain State are is a competence that is inextricably linked to the sovereign powers of the State itself. That being so, it will come as no surprise that States are not so eager to bind themselves by international treaties dealing with the State succession, which appears contrary to the principles of territorial integrity and the sovereignty of States. It is therefore not surprising that the ILC Draft Articles on Nationality of Natural Persons in relation to the Succession of States have not been transformed into a legally binding instrument or that the question of nationality of natural persons in relation to the succession of States has currently disappeared off the agenda of the General Assembly. ${ }^{787}$ Even in the case of the Council of Europe, the ECN, although being a legally binding instrument, has only been ratified by 20 out of 47 member States. ${ }^{788}$ Not surprisingly, Spain, Belgium and the United Kingdom are not amongst those States that have ratified the ECN. The Convention on the Avoidance of Statelessness in relation to State Succession has also attracted minimal ratifications, as only Austria, Hungary, Moldova, Montenegro, the Netherlands and Norway have ratified the convention. ${ }^{789}$

Thus, the analysis of the international legal instruments dealing with nationality issues arising in the context of State succession, although important to understand the complexity of this topic and the reluctance of the States to enhance the codification of such rules, does not provide any specific guidance on how States should deal with this issue. Furthermore, there is little consensus amongst scholars regarding the nature of these instruments as codifications of customary international law, since the practice of States is far from being regular and consistent. ${ }^{790}$ Ideally, the States involved should endeavour to reach an agreement on a set of applicable rules and to ensure that statelessness is obviated. Another desirable practice would be for the States involved in the State succession

\footnotetext{
787 See Chapter 2, section 5.1.

788 See Chapter 1, section 3.1.

789 See chapter 3 , section 3.

790 See Chapter 2, section 7.
} 
to provide accurate information regarding what the effects of a State succession on the nationality status would be, within a reasonable period of time, and paying particular attention to the exercise of right of option, if so provided, and the consequences that such a choice would have on their legal status.

In the case of the break up of an EU Member State it is imperative to address the issue of the new States membership to international organisations. In particular the question of whether the new independent State can start its life as an EU Member State has to be answered. The EU treaties provide no guidance on this particular situation. The lack of such a provision at EU level is, however, understandable when one considers that the territorial changes that take place in a State, even if that State is an EU Member State, fall within the exclusive competence of that State. Naturally, rules regarding EU membership are addressed to States that already exist as States. Expecting that an international organisation, like the EU, foresees the consequences of a possible break up of one its Members States and the automatic accession of the seceding part is contrary to the interests of its members. As explained above, States are reluctant to yield competences on powers that are strictly connected to the exercise of sovereignty. As such it will come as no surprise that States are not willing to establish binding international rules and ratify treaties that deal with nationality issues in a State succession scenario. This is due to the fact that they do not want to condone something that would jeopardise their territorial integrity.

Although some of the independence advocates in these regions conclude that they would be able to automatically accede to the EU as an independent State, the possibility of automatic accession of these territories to the EU is not supported by international law, or by the EU treaties themselves. ${ }^{791}$ The "internal enlargement" theory seems to overestimate the value of the EU citizenship status as currently designed. One cannot deny that citizenship of the Union could play a significant role in an eventual State succession which takes place in one of the EU Member States. However, this status is given to nationals of a Member State, that is, to individuals. Potential newly independent States overestimate the power of this status if they claim a right to an automatic succession to the EU upon independence. Consequently, from a legal perspective at least, the potential newly independent States must first acquire Statehood, before acceding to the EU.

For that reason, an interim period between independence and accession to the EU will, in principle, exist. Consequently, the newly independent

791 See Chapter 2, section 3. 
State is not a Member State of the EU and that territory is not bound by EU law. ${ }^{792}$ However, the fact that the new State is not a Member State of the EU does not imply that EU law is irrelevant for the nationality law issues arising as consequence of the independence process.

The predecessor State, that still retains its membership of the EU, must take into account EU law when determining the rules in respect of loss of nationality by nationals acquiring the nationality of the newly independent State. Furthermore, if the new State aspires to become a Member State of the EU, it should regulate its nationality law in such a way that is acceptable for the EU, in view of accession negotiations.

The influence of EU law on nationality decisions of the predecessor State is evident. The predecessor State cannot provide in its nationality law for an $e x$ lege withdrawal of its nationality to all its nationals residing in the territory of the newly independent State. That would amount to deprivation of the EU citizenship status without applying any kind of proportionality test, as was established in the Rottmann case. A right to opt for the nationality of the predecessor State or the nationality of the newly independent State has to be provided. Moreover, if the predecessor State would provide for the loss of its nationality when acquiring the nationality of the newly independent State that would amount to leaving the enjoyment of the EU citizen status in the hands of the newly independent State, that is not a Member State of the EU. In this regard, providing a right of option is highly important, especially in scenarios like the ones described in Catalonia and Scotland in which public opinion is clearly divided between the option of independence and the option of remaining as part of Spain and the United Kingdom respectively. It is at this point where the EU citizenship status plays a vital role. As discussed in Chapter 4, EU law has reduced the discretion of the Member States in nationality issues, due to the intrinsic connection between their nationalities and the citizenship of the Union.

A possible way for the nationals of the predecessor State to retain the status of citizen of the Union and, at the same time, acquire the nationality of the newly independent State is through dual nationality schemes. Nowadays, the approach of States towards dual nationality has changed thereby allowing individuals to possess multiple nationalities. Spain, Belgium and the United Kingdom accept dual nationality in their legal systems. In the case of the eventual independence of Catalonia, this approach towards dual nationality would be triggered by the idea of hispanidad. ${ }^{793}$ However, it is necessary to highlight first, that dual nationality schemes are only possible

\footnotetext{
792 See Chapter 2, sections 3 and 7.

${ }^{793}$ See Chapter 2, section 5.1.
} 
if the newly independent State would adopt the same approach towards dual nationality in its nationality legislation and therefore reciprocate the attitude of the remaining State in this respect. ${ }^{794}$ Otherwise, if the renunciation of the nationality of the predecessor State were established as a requirement to acquire the nationality of the newly independent State, this construction would not work. Secondly, one has to keep in mind that the EU citizenship status can only have effect within the territory of the EU. Thus, a dual Spanish-Catalan national cannot claim the application of EU law in a hypothetical independent Catalonia, at least not until the eventual accession of that country to the EU. And the same applies for TCNs and nationals of other EU Member States.

The potential newly independent State, i.e. a non-EU Member State is from the outset, not legally bound by EU law. However, the fact that the new State is not a Member State of the EU does not imply that EU law is irrelevant for the nationality law issues arising as consequence of the independence process. Given the will of the regions where independence is being discussed to accede to the EU, it does not seem wise for them to ignore EU law standards when drafting their nationality rules. For instance, a very generous policy when granting their nationality to third country nationals could reflect negatively on that State during the accession negotiations. ${ }^{795}$

Particular attention must be paid to the nationality position of minors. Traditionally minors ascertained, in a State succession scenario, the nationality of the head of the family, historically the nationality status of the father. The situation became more complicated since the principle of equal treatment of men and women was implemented into nationality law. As a consequence of this, both the successor State and the predecessor State have to regulate the nationality position of minors whose parents have a different nationality due to the State succession. It is challenging to develop rules determining which parent the minor should follow. It is not impossible to imagine a scenario in which certain strategic decisions have to be made to ensure that one of the parents retains the nationality of the predecessor State and the other acquires the nationality of the newly independent State. Which nationality should the minor follow in that case? Or should States allow the minor to have dual nationality in that case? ${ }^{796}$

794 However, it is questionable whether a newly independent State would be ready to accept, that all or most of its nationals also possess the nationality of the predecessor State.

795 See Chapter 4, section 5.

796 Compare Article 14(1)(a) of the ECN on the basis of which multiple nationality of minors should be accepted as a consequence of the equal treatment of men and women in respect of the transmission of their nationality to their children. 
Further complications arise as a result of the fact that in Catalonia and in Scotland minors who reached the age of 16 were eligible to participate in the respective independence queries. It would be highly problematic if they were forced to follow the nationality position of a parent upon independence. In the same way that minors above 16 years old were eligible to vote in the independence query, their will regarding the acquisition (or not, as the case may be) of a certain nationality upon independence must be taken into account. Otherwise, one is faced with the situation whereby a 16-year-old who voted against the independence acquires the nationality of newly independent State as a consequence of change of nationality by his/her parent(s) due to the operation of the laws on the extension of the acquisition of nationality and the fact that the nationality of the predecessor has been lost. Or a 16-year-old who voted in favour of independence, but cannot acquire the nationality of newly independent State as a consequence of his/her parent(s) decision to keep the nationality of the predecessor State. In this regard, one cannot accept the approach adopted in the Recommendation 2009/13 of the Committee of Ministers of the Council of Europe, according to which the right of minors to be heard is only applicable within the framework of nationality procedures but not in cases where the minor acquires or loses a nationality ex lege. ${ }^{797}$ In other words, minors would not be heard in all cases of acquisition or loss of nationality due to the ex lege application of rules on extension of the nationality from parent(s) to children in the context of State succession. This conclusion is unacceptable and, despite the absence of any international legal instrument addressing this specific situation, it would be highly recommendable to provide for a mechanism to assure that the will of minors is taken into account.

Having addressed the fact that minors aged 16 and 17 years-old were able to participate in the independence query, a side note on the participation of TCNs is needed. In the case of Scotland, the Scottish Independence Referendum (Franchise) Act 2013 stipulated that only British citizens resident in Scotland, Commonwealth citizens resident in Scotland, citizens of the Republic of Ireland, and citizens of other EU Member States resident in Scotland were eligible to vote. TCNs residing in Scotland were not eligible to vote. However, according to the nationality policy of the SNP upon independence, as provided in the White Paper "Scotland's Future: Your Guide to an Independent Scotland", non-British nationals who have spent at least ten years living in Scotland at any time and who have an on-going connection with Scotland may apply for Scottish nationality. Thus, although TCNs were not able to vote in the referendum, the possibility of naturalisation was foreseen by the SNP. EU citizens were able to vote and were also eligible for naturalisation.

${ }^{797}$ See Chapter 5, section 5. 
In the case of Catalonia, TCNs were eligible to vote in the "participatory process" insofar as they could prove their residence in Catalonia and were at least 16 years-old on 9 November 2014. Regarding the hypothetical acquisition of Catalan nationality by TCNs, Report No. 10 of the Advisory Council for the National Transition, which focused on the need to draft legislation in order to determine the scope of Catalan nationals at the time of the eventual independence, was silent on this issue. In contrast to the Scottish proposal, there is no specific recommendation regarding the acquisition of the Catalan nationality by foreign citizens residing in Catalonia, besides the non-official Constitutional proposal from Constituïm. Thus, citizens from other EU Member States and citizens from non-EU States would not be eligible for citizenship $a b$ initio in a hypothetical independent Catalonia, but nonetheless they were eligible to vote on the independence query.

Although the referendum itself does not entail the independence of a certain region, it constitutes the first step in an independence process that would have effects on the nationality status of the people residing in the secessionist territory, including TCNs. There is no obligation on behalf of the newly independent States to extend an offer of nationality to migrants. However, for individuals, and especially migrants, a vote in the referendum or consultation must be an informed one, and a lack of understanding as to who would be citizens after any vote is not acceptable. Ideally, a general proposal on nationality policy should be provided before the independence, or more desirably, before the referendum takes place.

Whereas the new State will not be an immediate Member State of the EU and bound by EU law upon independence, the situation differs in respect of the obligations flowing from the ECHR. The three States that have been studied in the present research are members of the Council of Europe and are bound by the ECHR. Furthermore, the potential newly independent States will also become a member of the Council of Europe. Besides their will to become members of the Council of Europe, at leastas expressed in the White Paper "Scotland's Future: Your Guide to an Independent Scotland"798 for Scotland and the White paper on "The National Transition of Catalonia" for Catalonia ${ }^{799}$ it is necessary to consider the possible application of the doctrine developed by the ICJ and the ECtHR regarding the automatic State succession to human rights treaties. ${ }^{800}$ Even if this doctrine was not considered to be applicable, it must be noted in this context that the ECtHR

\footnotetext{
798 See the 2013 White Paper "Scotland's Future: Your Guide to an Independent Scotland", p. 227.

799 See the 2014 White paper on "The National Transition of Catalonia", p. 126.

800 See Chapter 2, section 4.
} 
applied the convention rights in the Kurić case to a situation created by the legislation passed by the Slovenian Government, before the entry into force of the Convention in respect of Slovenia. Following the rationale of the ECtHR, the Kurić doctrine would be applicable in the case of the eventual independence of Catalonia, Flanders or Scotland even if those territories do not automatically apply the convention. If the nationality legislation enacted upon independence continues to adversely affect a certain group of people who previously enjoyed the right to reside in those territories, the ECtHR would have jurisdiction in order to protect their resident status. ${ }^{801}$

In Kurićand others v Slovenia, the ECtHR dealt with a case of State succession, i.e., the dissolution of the Socialist Federal Republic of Yugoslavia. Certain similarities can be observed between the situation at stake in Kurić and eventual independence of part of an EU Member State. Before its independence, Slovenia was one of six republics within the federation of Yugoslavia. Nationals of the SFRY enjoyed "dual citizenship" for internal purposes, meaning that they were citizens of both the federation and one of the six republics. ${ }^{802}$ They had freedom of movement within the federation and had the right to acquire permanent residence when certain criteria were met. That permanent residence was the key to fully enjoying civil, economic, political and social rights. That status of permanent residence was linked to being a citizen of the federation, that is, SFRY nationals could gain permanent residence status in Slovenia, or in any another constituent republic, as SFRY nationals.

The resemblance to the situation of nationals of EU Member States is salient: nationals of Member States are also citizens of the Union and, within the EU they enjoy as a set of rights inter alia the freedom of movement and establishment. Similarly to SFRY nationals, EU citizens can acquire permanent residence when certain criteria have been met in any EU Member State.

The message of Kurić was clear: withdrawing the right to permanent residency to former SFRY nationals upon independence was, inter alia, a violation of the Convention right to private and family life. Following the thesis firstly developed by Vidmar, this means, in the scenario of an eventual independence of Catalonia, Flanders or Scotland, that the residence rights of certain categories of people residing, not only on the territory of the potential newly independent State, but also in the predecessor States

\footnotetext{
${ }^{801}$ See Chapter 5, section 2.
}

802 See Chapter 5, section 1.1. 
and other EU Member States are protected ${ }^{803}$ However, that protection is limited to the residence rights enjoyed at the moment of independence and within the territory on which that residence has been established. ${ }^{804}$ Accordingly, it seems more appropriate, following Vidmar's idiolect, to refer to a set of rights that are being "frozen" than protected, especially when this protection is territorially restricted ${ }^{805}$ The right to remain in the territory of the newly independent State, the predecessor State or other EU Member State shall be ensured in any case by the application of the Kurić formula. Ideally, nationals of the newly independent States residing in the predecessor State or other EU Member States, nationals of the predecessor State (or other EU Member States) residing in the newly independent States and TCNs residing in the new States should continue to have their residence rights protected on that territory. From a practical day-to-day perspective, their position should not change and their right to private and family life, strictly linked to their residence status, should be respected.

However, the way that the residence entitlement would be frozen will depend on different factors, i.e., the enjoyment, at least until the moment of independence, of the status of citizen of the Union and the territory in which those residence rights are being exercised ${ }^{806}$ Although possession of the nationality of an EU Member State is the conditio sine qua non for the enjoyment of the EU citizenship status; being a European citizen up until the time of independence could actually make a difference. This difference can be observed when applying the Council Directive concerning the status of TCNs who are long-term residents to former EU citizens that, due to the State succession, have lost that status and are residing on EU territory. It seems neither logical nor realistic to require former EU citizens to comply with integration conditions, especially in the case of former nationals of the predecessor State still residing in the territory of the that State after independence. ${ }^{807}$ Similarly, the safeguards regarding the expulsion of Union citizens on grounds of public policy or public security should be applicable to those former Union citizens. ${ }^{808}$

The territory on which the residence has been established before independence is also relevant for the protection of the residence rights. Whilst the Kuric formula could also be applicable in the territory of the newly independent States, these States are not EU Member States from the

\footnotetext{
${ }^{803}$ See Chapter 5, section 2.

${ }^{804}$ See Chapter 5, section 2.

805 See Chapter 5, section 2.

${ }^{806}$ See Chapter 5, section 2.

807 See Chapter 5, section 3.

808 See Chapter 5, section 3.
} 
date of its independence. Thus, the application of the Directive concerning the status of TCNs who are long term residents or the Directive on the right of citizens of the Union and their family members to move and reside freely within the territory of the Member States would not be possible in order to improve the residence rights of former EU citizens in order to guarantee certain derived mobility rights. ${ }^{809}$ Furthermore, within the territory of the EU, those former EU citizens residing in the territory of the United Kingdom, Ireland and Denmark could not benefit from the application of the Directive concerning the status of TCNs that are who are long term residents, given the opt-out of these EU Member States from the area of freedom, security and justice ${ }^{810}$ In other words, the protection of the residence rights of the aforementioned categories of persons would completely depend on the application of the Kurić formula.

The Kurić formula becomes even more important in the context of "Brexit" and the protection of residence rights of British citizens living in the EU post-"Brexit" and EU citizens residing in the United Kingdom post-"Brexit". In both cases, the Kurić formula will apply, protecting the residence rights of both British citizens residing outside the United Kingdom (but within the EU) who do not possess the nationality of an EU Member State and citizens of the Union residing in the United Kingdom. Although the facts in the Kurić decision and the "Brexit" situation may differ, the overall premise is the same: residency which has been lawfully established prior to the "Brexit" and, when the United Kingdom finally proceeds with its withdrawal from the $\mathrm{EU}^{811}$ that right of residence will be retained, even if the nationality status would not be enough to ensure a right to residence in the United Kingdom for citizens of the Union or in the EU for British citizens. Furthermore, since no question related to statehood will arise in the "Brexit" context (with the exception of a potential second independence referendum in Scotland triggered by the EU membership referendum) there would be no obstacle in the application of Article 8 of the ECHR, since the United Kingdom and all EU Member States are bound by that Convention.

Civis Europaeus sum? This question, that concluded the introductory chapter, is the cornerstone of this thesis. Besides the complex legal issues surrounding an eventual State succession within an EU Member State, this is the question that people affected by that situation need an answer to. The link between the nationality of an EU Member State and the citizenship of

809 See Chapter 5, section 3.1.

810 See Chapter 5, section 3.1.

811 At the time of writing, the process for the United Kingdom's withdrawal from the European Union has just started. 
the Union is, as it stands now, unbreakable. One cannot claim the enjoyment of the latter without holding the nationality of an EU Member State. Thus, those who, due to the operation of the State succession and the rules enacted in that context regarding nationality, lose the nationality of the predecessor-EU Member State cannot invoke "civis europaeus sum". From the outset, individuals who lose the nationality of a Member State would lose EU citizenship and the rights associated to it. However, whilst EU citizenship is still not autonomous from Member State nationality, certain rights associated to the residence in both the potential newly independent States and the EU Member States can be frozen as an interim solution until such times as the former has completed the accession process.

The role of EU citizenship in this scenario cannot be overemphasised. Given the state of affairs, citizenship of the Union is not enough, at least from the legal point of view, to defend the automatic accession of the potential newly independent States. These new States cannot circumvent the accession procedure to the EU. Notwithstanding, EU citizenship has a role to play through the influence of EU law on the nationality law of the remaining EU Member States and, especially, the application of the proportionality principle in decisions on loss of nationality.

In this context, the EU institutions should also play an assisting role. The amendment of the EU treaties or enactment of EU legislation addressing a hypothetical separation of part of the territory of a Member State seems rather unrealistic, and indeed unadvisable. An international organisation in which its Member States decide to regulate the possible break-up of a State seems - to put it mildly - somewhat contradictory. However, it is salient to distinguish between the effects of such a situation for the Member States and for the European citizens and TCNs residing in the territories affected by the State succession. It is obvious, that the implementation of the "frozen" rights approach following from the Kurić formula is essential in order to avoid a substantial loss of rights by persons who lose their status as European citizens but still continue to live in a Member State of the EU as TCNs and also essential for European citizens and TCNs who find themselves living in a newly independent State, which is located outside the EU. Nothing prevents the European Commission from issuing certain recommendations on how to apply the Kurić formula or how to deal with former EU citizens that, due to the State succession, have lost that status.

Many voices have been raised supporting and opposing the eventual independence of these regions. This is a topic that raises passions and strong views. Many arguments have been put on the table, not always based on the current legal framework or, more generally, based on "reality". The most recent example of this was the debate preceding the United Kingdom's referendum on their membership of the EU. One thing 
is clear: we need a truthful and fair discussion in which the repercussions of an eventual independence on individuals should be correctly explained. The implications of such an event are important enough to avoid falling into dubious reasoning and argumentation. Nevertheless, at the same time, the passion and commitment demonstrated are also proof that the EU project is more alive than ever and that being a civis europaeus is a treasured conquest. 



\section{Bibliography}

A Campo, L., Shaping the concept of European Union Citizenship: Civis Europeus sum?, Masther thesis, Maastricht University, 2012.

Andrés Sáenz de Santa María, P., Sistema de Derecho Internacional Público, Aranzadi, Navarra, 2014 ( $3^{\text {rd }}$ edition).

Annemans, G., and Utsi, S., De ordelijke opdeling van België, Uitgeverij Egmont (ed.), Brussels, 29 October 2010 (1st edition), 11 June 2012 (5th edition).

Annemans, G., and Utsi, S., After Belgium, the orderly split-up, Uitgeverij Egmont (ed.), Brussels, 8 June 2011 (3rd edition).

Athanassiou, P. and Laulhé Shaelou, S., "EU Accession from Within?-An Introduction", Yearbook of European Law, 2014, pp. 335-384.

Barcells González, A. (ed), Pérez, A., Sabaté, F., and Simon, A., Història de Catalunya, L'esfera dels llibres, Barcelona, January 2005.

Barnard, C., "Of Students and Babies", The Cambridge Law Journal, 2005, pp. 560-563.

Beran, H., "A Liberal Theory of Secession", 32 Political Studies, 1984, pp. 21-31.

Blackman, J. L., "State Successions and Statelessness: The Emerging Right to an Effective Nationality under International Law", Michigan Journal of International Law 19, Vol. 4, 1998, pp. 1141-1194.

Borrás Rodríguez, A., "Jurisprudencia del Tribunal de Justicia de las Comunidades Europeas", Revista Jurídica de Catalunya, 1993, pp. 584-587.

Borrás Rodríguez, A., and Pellisé, C., "Jurisprudencia del Tribunal de Justicia de la Unión Europea”, Revista Jurídica de Catalunya, 2010, pp. 289-290.

Boswell C., and Geddes, A., Migration and Mobility in the European Union, Palgrave Macmillan, Basingstoke, 2010.

Bouza I Vidal, N., "El ámbito personal de aplicación del derecho de establecimiento en los supuestos de doble nacionalidad: comentario a la 
Sentencia del TJCE de 7 julio de 1992 en el caso Micheletti c. Delegación del Gobierno de Cantabria (As. C-369/90)", Revista de Instituciones Europeas, 1993, pp. 563-581.

Breunig, G., Staatsangehörigkeit und Entkolonisierung. Die Abgrenzung des Staatsvolkes bei der Verselbständigung der frankophonen Staaten Schwarzafrikas unter völkerrechtlichen Gesichtspunkten, Duncker \& Humblot, Berlin, 1974.

Brownlie, I., Principles of Public International Law, Clarendon Press, Oxford, 1990 (4 $4^{\text {th }}$ edition).

Brockman-Hawe, B. E., "European Court of Human Rights Bijelic v Montenegro and Serbia (Application No 19890/05) Judgment of 11 June 2009", International and Comparative Law Quarterly, 59, 2010, pp. 845867.

Brölmann, C., and Vandamme, T., Secession within the Union: Intersection points of International and European Law, Amsterdam Centre for European Law and Governance and Amsterdam Center for International Law, July 2014, pp. 3-7.

Buchanan, A., Secession: The Morality of Political Divorce from Fort Sumpter to Lithuania and Québec, Westview Press, Boulder, 1991.

Burlet, J., Nationalité des personnes physiques et décolonisation, Bruylant, Brussels, 1975.

Carrera Núñez, S., "How much does EU citizenship cost? The Maltese citizenship-for-sale affair: A breakthrough for sincere cooperation in citizenship of the union?", Centre for European Policy Studies, Liberty and Security in Europe Paper No. 64, 2014, pp. 1-52; also in Carrera Núñez, S., and De Groot, G.-R., (eds.), European Citizenship at the Crossroads, The Role of the European Union on Loss and Acquistion of Nationality, Wolf Legal Publishers, Oisterwijk, 2015, pp. 293-326.

Carrera Núñez, S., and De Groot, G.-R., (eds.), European Citizenship at the Crossroads, The Role of the European Union on Loss and Acquistion of Nationality, Wolf Legal Publishers, Oisterwijk, 2015.

Carrera Núñez, S. and Marrero González, G., "La ciudadanía europea en venta. El programa de venta de la nacionalidad maltesa: $¿$ una brecha en el principio de cooperación leal en el ámbito de la ciudadanía de la Unión?, Revista de Derecho Comunitario Europeo, 49, 2014, pp. 847-885. 
Casana Adam, E., "The Independence Referendum and Debates on Catalonia's Constitutional Future", Tijdschrift voor Constitutioneel Recht, 2014, pp. 162-171.

Casanovas, O., Rodrigo, A. J., Compendio de Derecho Internacional Público, Tecnos, Madrid, 2014 (3rd edition).

Cassese, A., International Law, Oxford University Press, New York, 2005 ( $2^{\text {nd }}$ edition).

Castillo Ortiz, P. J., "Framing the Court: Political Reactions to the Ruling on the Declaration of Sovereignty of the Catalan Parliament", Hague Journal on the Rule of Law, 7 (1), 2015, pp. 27-47.

Cazorla, M. I., La sucesión de estados y sus efectos sobre la nacionalidad de las personas físicas, Servicio de Publicaciones e Intercambio Científico de la Universidad de Málaga (ed.), Málaga, 2001.

Chamon, M., and Van der Loo, G., "The Temporal Paradox of Regions in the EU Seeking Independence: Contraction and Fragmentation versus Widening and Deepening?", European Law Journal, 2014, p. 613-629.

Chanock, M., Unconsummated Union: Britain, Rhodesia and South Africa, 1900-45, Machester University Press, Manchester, 1977.

Clapham, A., Brierly's Law of Nations, Oxford University Press, Oxford, 2012.

Closset, C.-L., Traité practique de la nationalité Belge, Bruylant, Brussels, 1970.

Connolly, C. K., "Independence in Europe: Secession, Sovereignty, and the European Union", Duke Journal of Comparative \& International Law, Vol. 24, 2013, pp. 51-105.

Cortés Martín, J. M., "Ciudadanía de la Unión, nacionalidad de los Estados Miembros y estatuto de apatridia, STJEU (Gran Sala) de 2 marzo de 2010, Rottmann C-135/08", Revista de Derecho Comunitario Europeo, 2010 no. 36, pp. 599-602.

Costes, M., Des Cessions de Territoires. Envisagées dans leur príncipe et dans leurs effects relatifs au changement de souveraineté et de nationalité, Rivière and Diron, Paris and Toulouse, 1914. 
Crawford, J., The Creation of States in International Law, Oxford Scholarship Online, Oxford, 2007 (2nd edition).

Crawford, J. and Boyle, A., "Annex A-Opinion: Referendum on the Independence of Scotland-International Law Aspects", Scotland Analysis: Devolution and the Implications of Scottish Independence, United Kingdom Government, 2013.

Craig, P., and de Búrca, G., EU Law. Text, cases, and materials, Oxford University Press, Oxford, 2015 (6th edition).

Cryer, R., Hervey, T., and Sokhi-Bulley, B., Research Methodologies in EU and International Law, Hart Publishing, Oxford and Portland, 2011.

Cuadras Morató, X. (ed.), Catalonia: A New Independent State in Europe?: A Debate on Secession within the European Union, Routledge, London, 2016.

Daniel, J., "La consultation populaire du 7 décembre 2003 et ses implications", Pouvoirs dans la Caraïbe, 15, December 2003.

Dembour, M.-B., When Humans Become Migrants. Study of the European Court of Human Rights with an Inter-American Counterpoint, Oxford University Press, 2015.

Deschouwer, K., The Politics of Belgium: Governing a Divided Society, Basingstoke, Palgrave Macmillan, 2009.

De Groot, G.-R., "Negeert Spanje de Micheletti-beslissing van het Europese Hof van Justitie?", Migrantenrecht, 1998, pp. 123-124.

De Groot, G.-R., "The relationship between the nationality legislation of the Member States of the European Union and European citizenship", in: M. La Torre (ed.), European Citizenship: An Institutional Challenge, 1998, pp. 115-147.

De Groot, G.-R., "Towards a European Nationality Law", in: Hildegard Schneider (ed.): Migration, Integration and Citizenship, A Challenge for Europe's Future, Vol. I, Forum Maastricht, May 2005, pp. 13-54.

De Groot, G.-R., Achtentwintig Nederlanders? Bewerkte adviezen en casus over de toepassing van de Nederlandse nationaliteitswetgeving, Elsevier Overheid, 's Gravenhage, 2007.

De Groot, G.-R., and Seling, A., "The consequences of the Rottmann judgment on Member State autonomy - The European Court of Justice's 
avant-gardism in nationality matters", European Constitutional Law Review, 2011, pp. 150-160; also published in: Jo Shaw (ed): Has the European Court of Justice Challenged Member State Sovereignty in Nationality Law? (RSCAS Working Paper 2011/62), Florence: EUI 2011, pp. 27-31.

De Groot, G.-R., "Equal Treatment of Women and Men in Nationality Law", in: Westendorp, I. (ed.), The Women's Convention Turned 30: Achievements, Setbacks, and Prospects, Cambridge-Antwerp-Portland, Intersentia, 2012, pp. 185-200.

De Groot, G.-R., "Strengthening the position of children: Council of Europe's Recommendation (2009) 13", in: Witjens, E., Van Bogaert, V., Bollen, C. (eds.), E Hofi di Ley, The Hague, 2014, pp. 483-484.

De Groot, G.-R., "Survey on Rules on Loss of Nationality in International Treaties and Case Law", in Sergio Carrera Núñez and Gerard-René De Groot (eds.), European Citizenship at the Crossroads, The Role of the European Union on Loss and Acquistion of Nationality, Wolf Legal Publishers, Oisterwijk, 2015, pp. 9-40.

De Groot, G.-R., "Case 6: The fate of Janko Rottmann", in Sergio Carrero Núñez and Gerard-René de Groot (eds.), European Citizenship at the Crossroads. The Role of the European Union on Loss and Acquisition of Nationality, Wolf Legal Publishers, Oisterwijk, 2015, pp. 383-396.

De Groot, G.-R. and Vonk, O., International standards on nationality law: text, cases and materials, Wolf Legal Publishers, Oisterwijk, 2016.

De Landas Wyborgh, A. M. D. S., Het Berlijnsche Tractaat van 26 February 1885, Mouton \& Co, 's-Gravenhage, 1886.

De Waele, H., "Afscheiding van delen van EU-lidstaten - Een beschouwing vanuit internationaal en Europeesrechtelijk perspectief", Ars Aequi vol. 10, 2014, pp. 722-725.

De Waele, H., "Afscheiding van delen van EU-lidstaten -de Europeesrechtelijke implicaties", SEW, 2016/2.

De Winter, L., "Belgium: from federalism to confederalism or to a big bang in 2014?", Cuadernos Manuel Giménez Abad, No. 4, December 2012, pp. 1629.

De Witte, B., "EU Law: Is it International Law?", in Barnard, C., and Peers, S., (eds.), European Union Law, Oxford University Press, Oxford, 2014, pp. 174-19. 
Diez de Velasco, M., Instituciones de Derecho Internacional Público, Tecnos, Madrid, 2013 (18th edition).

Dixon, M., McCorquodale, R., and Williams, S., Cases and Materials on International Law, Oxford University Press, Oxford, 2011 ( $5^{\text {th }}$ edition).

Douglas-Scott, S., "How Easily Could an Independent Scotland Join the EU?", Oxford Legal Studies Research Paper No. 46, 2014, pp. 2-25.

Dörr, O., "Nationality", in: R. Wolfrum (ed.), Max Planck Encyclopedia of Public International Law, Oxford University Press, 2006.

Edward, D., "European Law and the Separation of Member States", Fordham International Law Journal, 2013, pp. 1151-1168.

Emerson, M. (ed), Britain's Future in Europe: The Known Plan A to Remain or the Unknown Plan B to Leave, CEPS, Rowman \& Littlefield, London, 2016.

Emerson, M., "Scotland knows what it wants with the EU, while London seems still not to know", CEPS, 24 December 2016.

Entrena Cuesta, R., in Fernando Garrido Falla et al, Comentarios a la Constitutición, Civitas, Madrid, 1985.

Ert, G. V., "Nationality, State succession, and the right of option: the case of Québec", 36 Canadian Yearbook of International Law, 1998, pp. 151-180.

Espinar Vicente, J. M., "La "resolución"de los conflictos de nacionalidad en el Derecho comunitario", La ley - Comunidades Europeas, 1994, no. 84, pp. 1-5.

Evans, M. D., International Law, Oxford University Press, Oxford, 2010 (3rd edition).

Farley, B.R., "Calling a State a State: Somaliland and International Recognition”, Emory International Law Review, Vol. 24, No. 2, 2010, pp. 777-820.

Fentiman, R., "Domicile Revisited", The Cambridge Law Journal, 50, 1991, pp. 445-463.

Fernández Tomás, A., Sánchez Legido, A., Ortega Terol, J. M., Manual de Derecho Internacional Público, Tirant lo Blanch, Valencia, 2004.

Fernández Tomas, A., F., Sánchez Legido, A., Ortega Terol, J. M., Forcada Barona, I., Lecciones de Derecho Internacional Público, Tirant lo Blanch, Valencia, 2011. 
Ferreres Comella, V., "The Spanish Constitutional Court Confronts Catalonia's "Right to Decide" (Comment on the Judgment 42/2014)", European Constitutional Law Review, 2014, pp. 571-590.

Fransman, L., Fransman's British Nationality Law, Bloomsbury Professional, West Sussex, 2011 (3rd edition).

García Andrade, P., "La ciudadanía europea y la sucesión de Estados: a vueltas con las implicaciones de una separación territorial en el seno de la UE", Revista de Derecho Comunitario Europeo, 49, 2014, pp. 997-1025.

Glahn, G. v., and Taulbee, J. L., Law Among Nations, Pearson Longman, New York, 2007 ( $8^{\text {th }}$ edition).

González Campos, J. D., Sánchez Rodríguez, L. I., Andrés Sáenz de Santa María, P., Curso de Derecho Internacional Público, Aranzadi, Navarra, 2008 ( $4^{\text {th }}$ edition revised).

Gounin, Y., "Les dynamiques d'éclatements d'États dans l'Union européenne: cassetête juridique, défi politique", Politique étrangère, Vol. 4, 2013, pp. 11-22.

Gowlland-Debbas, V., "The Role of the International Court of Justice in the Development of the Contemporary Law of Treaties", in Tams, C. J., and Sloan, J. (eds.), The Development of International Law by the International Court of Justice, Oxford Scholarship Online, Oxford, January 2014.

Grant, T.D., The Recognition of States: Law and Practice in Debate and Evolution, Greenwood Publishing Group, Westport, 1999.

Graupner, R., "Nationality and State Succession: General Principles of the Effect of Territorial Changes on Individuals in International Law", Transactions of the Grotius Society Vol. 32, 1946, pp. 87-120.

Grewe, W. G., The Epochs of International Law, Walter de Gruyter, BerlinNewYork, 2000.

Gruss, D., "UNTEA and West New Guinea", in: von Bogdandy, A., and Wolfrum, R. (eds.), Max Planck Yearbook of United Nations Law, vol. 9, 2005, pp. 97-126.

Guibernau, M., "Prospects for an independent Catalonia", International Journal of Politics, Culture and Society, Vol. 27, 2014, pp. 5-23. 
Guibernau, M., "Catalonia: Will Catalans be permitted to hold a legally binding referendum on independence?", Kick-off contribution, European University Institute, Robert Schuman Centre for Advanced Studies, Florence, 2014, p. 15.

Guild, E., BREXIT and its Consequences for UK and EU Citizenship or Monstrous Citizenship, Brill Nijhoff, Leiden-Boston, 2017.

Haljan, D., Constitutionalising Secession, Hart Publishing, Oxford and Portland, 2014.

Hall, S., "Determining the Scope ratione personae of European Citizenship: Customary International Law Prevails for Now. ECJ Judgment, 20 February 2001, Case C-192/99, The Queen v. Secretary of State for the Home Department ex parte Kaur", Legal Issues of Economic Integration, 2001, pp. 355-360.

Happold, M., "Independence: In or Out of Europe? An Independent Scotland and the European Union", The International and Comparative Law Quarterly Vol. 49, No. 1, pp. 15-34.

Harhoff, F., "Greenland's withdrawal from the European Communities", Common Market Law Review, Vol. 13, 1983, pp. 13-33.

Harvie, C., Scotland and Nationalism. Scottish society and politics 1707 to the present, Routledge, London-New York, 2004 (4th edition).

Heintz, M., "The Freedom to Achieve Freedom: Negotiating the Anglo-Irish Treaty," Intersections 10, no. 1, 2009, pp. 431-451.

Hofstötter, B., "A cascade of rights, or who shall care for little Catherine? Some reflections on the Chen case", European Law Review, 2005, pp. 548558.

Iglesias Buhigues, J. L., "Doble nacionalidad y Derecho comunitario: A propósito des asunto C-369/90, Micheletti, sentencia del TJCE de 7 julio de 1992", in: Hacia un nuevo orden internacional y europeo. Estudios en homenaje al profesor don Manuel Díez de Velasco, Tecnos, Madrid 1993, pp. 953-967.

Jellinek, G. and Jellinek, W., Allgemeine Staatslehre, Julius Springer, Berlin, 1929 ( $3^{\text {rd }}$ edition).

Jessurun d'Oliveira, H.-U., "Case note", Common Market Law Review, 1993, pp. 623-637. 
Jessurun d'Oliveira, H.-U., “Decoupling Nationality and Union Citizenship?”, European Constitutional Law Review, 2011, pp. 138-149.

Jiménez Piernas, C., Introducción al Derecho Internacional Público. Práctica de España y de la Unión Europea, Tecnos, Madrid, 2011.

Jones, J.M., British Nationality Law and Practice, Clarendon Press, Oxford, 1947.

Kamminga, M., "State Succession in Respect of Human Rights Treaties", 7 European Journal of International Law, 1996, pp. 469-484.

Keating, M., "European Integration and the Nationalities", Question Politics \& Society, vol. 32 no. 3, September, 2004, pp. 367-388.

Kelly, M. J., "Pulling at the Threads of Westphalia: Involuntary Sovereignty Waiver, Revolutionary International Legal Theory or Return to Rule by the Great Powers?", UCLA Journal of International Law \& Foreign Affairs, Vol. 10, No. 2, pp. 361-440.

Kenealy, D., "How Do You Solve a Problem like Scotland? A proposal Regarding 'Internal Enlargement', Journal of European Integration Vol. 36, No. 6, pp. 585-600.

Keresztes, P., "The Constitutio Antoniniana and the Persecutions under Caracalla", The American Journal of Philology, Vol. 91, No. 4, October 1970, pp. 446-459.

Kochenov, D., "Ius Tractum of Many Faces: European Citizenship and the Difficult Relationship between Status and Rights", Columbia Journal of European Law, Vol. 15, No. 2, 2009, pp. 169-237.

Kochenov, D., "EU Citizenship and Withdrawals from the Union: How Inevitable Is the Radical Downgrading of Rights?", LEQS paper, No. 111, 2016, pp. 1-30.

Kochenov, D., "A Real European Citizenship: A new Jusrisdiction Test; A Novel Chapter in the Development of the Union in Europe", Columbia Journal of European Law, Vol. 18, No. 1, 2011, pp. 56-109.

Kunkel, W., and Schermaier, M., Römische Rechtsgeschichte, Böhlau, Köln, Weimar, Wien, 2005 (14 ${ }^{\text {th }}$ edition).

Kunoy, B., "A Union of National Citizens: the Origins of the Court's Lack of AvantGardisme in the Chen Case", Common Market Law Review, 2006, pp. 179-190. 
Kunz, J., L., Die Völkerrechtliche Option, Hirt, Breslau, 1928.

Lenaerts, K., "'Civis europaeus sum': from the cross-border link to the status of citizen of the Union" Online Journal on free movement of workers within the European Union, No. 3, Luxemburg, 2011, pp. 6-18.

Lewis, A., "Slavery, Family, and Status" in: Johnston, D. (ed.), The Cambridge companion to Roman Law, Cambridge, 2015, pp. 151-174.

López Hernández, J., "A Catalan perspective: franchise in a forbidden referendum", Kick-off contribution, European University Institute, Robert Schuman Centre for Advanced Studies, Florence, 2014, p. 6.

Lozano Serralta, M., La nacionalidad en los territorios dependientes, Madrid, Consejo Superior de Investigaciones Científicas, 1955.

Maas, W., Creating European Citizens (Europe today), Rowman \& Littlefield Publishers, Lanham, Boulder, New York, Toronto, Plymouth, 2007.

Mangas Martín, A., "La Secesión de Territorios en un Estado Miembro: efectos en el Derecho de la Unión Europea", Revista de Derecho de la Unión Europea No. 25, July-December 2013, pp. 47-68.

Marrero González, G., "Catalonia's independence and the role of the Constitutional Court: recent developments",Tijdschrift voor Constitutioneel Recht, 2015, pp. 86-94.

Marrero González, G., "The role of migrants in the Catalan independence process: a legal analysis", Pro-independence Movements and Immigration: Discourse, Policy and Practice, Roberta Medda-Windischer and Patricia Popelier (eds.), 2016, pp. 161-207.

Matas, J. et al, The internal enlargement of the European Union, Centre Maurits Coppieters, Brussels, 2010.

Medda-Windischer, R., and Popelier, P. (ed), Pro-independence Movements and Immigration: Discourse, Policy and Practice, Brill Nijhoff, Leiden Boston, 2016.

Meessen, K., M., Die Option der Staatsangehörigkeit, Duncker and Humblot, Berlin, 1966.

Miaja de la Muela, A., Introducción al Derecho Internacional Público, Atlas, Madrid, 1979 ( $7^{\text {th }}$ edition). 
Mnookin, R., and Verbeke, A., "Persistent Nonviolent Conflict with No Reconciliation: The Flemish and Walloons in Belgium", Law and Contemporary Problems, Vol. 72, No. 2, 2009, pp. 151-186.

Nicolaides, P., "Withdrawal from the European Union: A Typology of Effects', Maastricht Journal of European and Comparative Law, 2013, pp. 209-219.

Oderkerk, M., "The need for a Methodological Framework for Comparative Legal Research. Sense and Nonsense of 'Methodological Pluralism' in Comparative Law", Nederlandse Vereniging voor Rechtsvergelijking, Vol. 73, 2016, pp. 1-32.

Oppenheim, L. and Roxburg, R., International Law: A Treatise, Longmans, vol. 1, London, 1920.

Palomares Amat, M., "Ciudadanía de la Unión, nacionalidad y derecho de voto a las elecciones al Parlamento Europeo. Comentario a las Sentencias des TJCE de 12 de septiembre de 2006 (Asuntos C-145/04 y C-300/04)", Noticias de la Unión Europea, 2008, no. 282, pp. 43-48.

Pastor Ridruejo, J. A., Curso de Derecho Internacional Público y Organizaciones Internacionales, Tecnos, Madrid.

Pellet, A., The Opinions of the Badinter Arbitration Committee A Second Breath for the Self-Determination of Peoples, European Journal of International Law , 3 (1), 1992, pp. 178-185.

Pérez Vera, E., "El sistema español de doble nacionalidad ante la futura adhesión de España a las Comunidades Europeas", Revista de instituciones Europeas, 1991, pp. 65-73.

Pilgram, L., International Law and European Nationality Laws, European University Institute, Florence, Robert Schuman Centre for Advanced Studies, EUDO Citizenship Observatory, March 2011.

Peers, S., "UK and Irish opt-outs from EU Justice and Home Affairs (JHA) law", Statewatch EU Lisbon Treaty Analysis, 3 November 2009, pp. 1-28.

Raič, D., Statehood and the Law of Self-Determination, Kluwer Law International, The Hague - London - New York, 2002.

Remiro Brotóns, A., Riquelme Cortado, R., Orihuela Calatayud, E., DíezHochleitner, J., Pérez-Prat Durban, L., Derecho Internacional. Curso general, Tirant lo Blanch, Valencia, 2010. 
Rodríguez Carrión, A. J., Lecciones de Derecho Internacional Público, Tecnos, Madrid, 2006.

Scharf, M. P., "Musical Chairs: The Dissolution of States and Membership in the United Nations", 28 Cornell International Law Journal, 1995, pp. 29-70.

Shah, P., "British Nationals under Community Law: The Kaur Case", European Journal of Migration and Law, 2001, pp. 271-278.

Shaw, J., "Citizenship in an independent Scotland: legal status and political implications", CITSEE Working Paper Series, vol. 34, 2013, pp. 1-39.

Shaw, J., "The Political Representation of Europe's Citizens: Developments", European Constitutional Law Review, 2008, pp. 162-186.

Shaw, M. N., International Law, Cambridge University Press, Cambridge, 2014 ( $7^{\text {th }}$ edition).

Sobrequés i Callicó, J., Estudis d'Historia de Catalunya, Edat Mitjana, Edat Moderna, El Pactisme, Editorial base, Vol. I, Barcelona, December 2008.

Schmidt, H.-A., Staatsangehörigkeitswechsel bei Staatensukzessionen, dissertation, Kiel, 1966.

Spiro, P. J., "A New International Law of Citizenship", American Journal of International Law, Vol. 105, No. 4, October 2011, pp. 694-746.

Standaert, R., La Nationalité Belge, Balsacq, Luttre, 1934.

Szlechter, E., Les options conventionelles de nationalité à la suite de cessions de territoires, Sirey, Paris, 1948.

Tatham, A. F., "Don't Mention Divorce at the Wedding, Darling!: EU Accession and Withdrawal after Lisbon", in Andrea Biondi et al (eds.), $E U$ Law After Lisbon, Oxford University Press, 2012.

Tavernier, P., "Aspects juridiques des relations économiques entre la CEE et l'Algérie", Revue trimestrielle de droit européen, Vol. 8, 1972, pp. 1-35.

Tierney, S., "Legal Issues Surrounding the Referendum on Independence for Scotland", European Constitutional Law Review, 2013, pp. 359-390.

Tratnik, M., Het nationaliteitsrecht in de oosteuropese landen, Kluwer, Deventer, 1989. 
Tryfonidou, A., "C-200/02, Kunqian Catherine Zhu and Man Lavette Chen v. Secretary of State for the Home Department: Further Cracks in the "Great Wall" of the European Union?", European Public Law, 2005, pp. 527-541.

Vandecasteele, B., Deville, F., and Vos, H., "Belgium, separatism, and the EU", Fair Observer, 2012, pp. 1-6.

Van den Driest, S., F., Remedial Secession: A right to External Selfdetermination and Secession, Intersentia, Antwerp-Oxford-Portland, 2013.

Van Wauwe, L., Federalisme, utopie ou possibilité?, Editions scientifiques Erasme - Libraire Generale de Droit et de Jurisprudence (ed.), Antwerp, Brussels, Paris, 1970.

Vaubel, R., "Secession in the European Union", Economic Affairs, Vol. 33, 2013, pp. 288-302.

Verstraete, M., La Nationalité Congolaise, Académie royale des Sciences coloniales, Vol. XX, part 3, Brussels, 1959.

Verstraete, M., "Le cumul des nationalités belge et congolais est-il possible?", Journal de tribunaux d'outre-mer, 1960, p. 64.

Vezzoli, S., Borders, independence and post-colonial ties: the role of the state in Caribbean migration, Boekenplan, Maastricht, 2015.

Vidmar, J., "International legal responses to Kosovo's Declaration of Independence", Vanderbilt Journal of Transnational Law 42, 2009, pp. 779851.

Vidmar, J., "Remedial secession in international law: theory and (lack of) practice", St Antony's International Review 6 (1), 2010, pp. 37-56.

Vidmar, J., "Territorial integrity and the law of statehood", George Washington International Law Review (44) 2013, pp. 101-149.

Vidmar, J., "The Scottish Independence Referendum in an International Context", Canadian Yearbook of International Law 51, 2013, pp. 259-288.

Viñes Taberna, R., Notas Históricas sobre el Sáhara Occidental, Ediciones del Cabildo de Gran Canaria, Las Palmas de Gran Canaria, 2003.

Wallace, R. M. M., International Law, Sweet and Maxwell, London, 2005 (5th edition). 
Wellman, C. H., A Theory of Succession: The Case for Political Selfdetermination, Cambridge University Press, Cambridge, 2005.

Wiesbrock, A., Legal Migration to the European Union: Ten Years After Tampere, Wolf Legal Publishers, Nijmegen, 2009.

Zelaia Garagarza, M., "La Ciudadanía de la Unión y el derecho a votar en las elecciones al Parlamento Europeo, Comentario a las Sentencias del Tribunal de Justicia de las Comunidades Europeas España c. Reino Unido, y Eman and Sevinger c. College van burgemeester en wethouders van Den Haag, de 12 de septiembre de 2006", Revista de Derecho Comunitario Europeo, 2007, pp. 91-123.

Ziegler, R., "Independence Referendums: Who should vote and who should be offered citizenship?", Kick-off contribution, European University Institute, Robert Schuman Centre for Advanced Studies, Florence, 2014, p. 1.

Ziemele, I., State Continuity and Nationality: The Baltic States and Russia : Past Present and Future as Defined by International Law, M. Nijhoff, Leiden, 2005.

Ziemele, I., "State succession and issues of nationality and statelessness", in Edwards, A., and van Waas, L., (eds.), Nationality and Statelessness under International Law, Cambridge University Press, Cambridge, 2014, pp. 217246. 


\section{Treaties, legislation, reports and other documents}

\section{United Nations documents}

Charter of the United Nations, 24 October 1945, 1 UNTS XVI.

UN General Assembly, Universal Declaration of Human Rights, 10 December 1948, 217 A (III).

Convention Relating to the Status of Stateless Persons, 28 September 1954, UNTS vol. 360.

UN General Assembly, Declaration on the Granting of Independence to Colonial Countries and Peoples, 14 December 1960, A/RES/1514(XV), Official Records of the General Assembly, Eighteenth Session, Annexes, addendum to agenda item 23 (A/54/46/Rev.1), annex I.

Convention on the Reduction of Statelessness, 30 August 1961, UNTS vol. 989.

Resolution 1686 (XVI) of 18 December 1961, Future work in the field of the codification and progressive development of international law, Official Records of the General Assembly, Fifteenth Session, Supplement No. 9 (A/4425).

The succession of States in relation to membership in the United Nations: memorandum prepared by the Secretariat, Doc. A7CN.4/149 and Add. 1, Yearbook of the International Law Commisssion, 1962, Vol. II.

Resolution 2072 (XX) of 16 December 1965, Question of Ifni and Spanish Sahara, Official Records of the General Assembly, Twentieth Session, Supplement No. 14 (A/6160).

International Covenant on Civil and Political Rights, 16 December 1966, UNTS vol. 999.

International Covenant on Economic, Social and Cultural Rights, 16 December 1966, UNTS vol. 993.

Resolution 2229 (XXI) of 20 December 1966, Question of Ifni and Spanish Sahara, Official Records of the General Assembly, Twenty-first Session, Supplement No. 16 (A/6623). 
Resolution 2354 (XXII) of 19 December 1967, Question of Ifni and Spanish Sahara, Official Records of the General Assembly, Twenty-second Session, Supplement No. 16 (A/7013).

Resolution 2428 (XXIII) of 18 December 1968, Question of Ifni and Spanish Sahara, Official Records of the General Assembly, Twenty-third Session, Supplement No. 18(A/7419).

Resolution 2591 (XXIV) of 16 December 1969, Question of Spanish Sahara, Official Records of the General Assembly, Twenty-forth Session, Supplement No. 30 (A/7896).

Declaration on Principles of International Law concerning Friendly Relations and Cooperation among States in accordance with the Charter of the United Nations, 24 October 1970, A/RES/2625(XXV).

Resolution 2711 (XXV) of 14 December 1970, Question of Spanish Sahara, Official Records of the General Assembly, Twenty-fifth Session, Supplement No. 28 (A/8248).

Resolution 2983 (XXVII) of 14 December 1972, Question of Spanish Sahara, Official Records of the General Assembly, Twenty-seven Session, Supplement No. 30 (A/8955).

Resolution 3162 (XXVIII) of 14 December 1973, Question of Spanish Sahara, Official Records of the General Assembly, Twenty-eight Session, Supplement No. 30 (A/9417).

Draft Articles on Succession of States in respect of Treaties with commentaries, Report of the Commission to the General Assembly, Yearbook of the International Law Commisssion, 1974, vol. II, Part One.

Resolution 3292 (XXIX) of 13 December 1974, Question of Ifni and Spanish Sahara, Official Records of the General Assembly, Twenty-first Session, Supplement No. 16 (A/6623).

Resolutions 3458 A-B (XXX) of 10 December 1975, Question of Spanish Sahara, Official Records of the General Assembly, Thirtieth Session, Supplement No. 34 (A/10427).

Report of the United Nations Visiting Mission to Spanish Sahara, Official Records of the General Assembly, Thirtieth Session, Supplement No. 23, 1975, (A/10023/Rev. I). 
Letter dated 26 February 1976 from the Permanent Representative of Spain to the United Nations addressed to the Secretary-General, Official Records of the Security Council, Thirty-first Year, Supplement for January, February and March 1976, (A/31/56-S/11997).

Vienna Convention on Succession of States in respect of Treaties, 23 August 1978 (Registered ex officio on 6 November 1996), UNTS vol. 1946.

Convention on the Elimination of All Forms of Discrimination Against Women, 18 December 1979, UNTS vol. 1249.

Vienna Convention on the Succession of States in Respect of Property Archives and Debts, 8 April 1983, UN Juridical Yearbook, 1983 (Sales No. E.90.V.1).

UN Commission on Human Rights Report of the Secretary-General, Status of the International Covenants on Human Rights: Succession of States in respect of international human rights treaties, 28 November 1994, E/ CN.4/1995/80.

UN Commission on Human Rights Resolution 1995/18, Succession of States in respect of international human rights treaties, 24 February 1995, E/CN.4/RES/1995/18.

Vaclav Mikulka, Special Rapporteur Succession of States with respect to Nationality / Nationality in relation to the succession of States 'First report on State succession and its impact on the nationality of natural and legal persons' A/CN.4/467, 1995 (Mikulka Report).

UN Human Rights Committee, CCPR General Comment No. 26: Continuity of Obligations, 8 December 1997, CCPR/C/21/Rev.1/Add.8/Rev.1.

International Law Commission, Articles on Nationality of Natural Persons in Relation to the Succession of States (With Commentaries), 3 April 1999, Supplement No. 10 (A/54/10).

Resolution 65 (XXXVIII) of 14 July 2011, Admission of the Republic of South Sudan to membership in the United Nations, Official Records of the General Assembly, Sixty-fith Session, Supplement No. 49 (A/65/L.84 + Add.1). 


\section{Council of Europe documents}

Declaration on the Consequences of State Succession for the Nationality of Natural Persons (and commentary), European Commission for Democracy through Law, 'Consequences of State Succession for Nationality' CDL-INF (97), 28th Plenary Meeting, Venice, September 1996.

European Convention on Nationality, Strasburg, 6 November 1997, ETS 166.

Explanatory Report to the European Convention on Nationality, 6 November 1997, ETS 166.

Convention on the Avoidance of Statelessness in Relation to State Succession, Strasbourg, 15 March 2006, ETS 200.

Recommendation CM/Rec (2009) 13 of the Committee of Ministers to member states of the Council of Europe on the nationality of children.

Explanatory memorandum to the Recommendation CM/Rec (2009) 13 of the Committee of Ministers to member states of the Council of Europe on the nationality of children.

\section{Multilateral treaties: varia}

League of Nations, Convention on Certain Questions Relating to the Conflict of Nationality Law, 13 April 1930, LNTS, vol. 179.

Montevideo Convention on the Rights and Duties of States (Montevideo, 26 December 1933) 165 LNTS 19.

Organization of American States (OAS), American Convention on Human Rights, "Pact of San Jose”, Costa Rica, 22 November 1969.

\section{Bilateral treaties}

Treaty of Peace and Amity between the Kingdom of Spain and the Kingdom of Morocco [Tratado de paz y Amistad entre los muy poderosos Príncipes S.M. Doña Isabel II, Reina de las Españas, y Sidi-Mohammed, Rey de Marruecos, Fez, Mequinez \& c.], Gaceta de Madrid, n. 157, 5 April 1860. 
Treaty of Luxemburg (Vertrag von Luxemburg: Vertrag zwischen der Bundesrepublik Deutschland und der Französischen Republik zur Regelung der Saarfrage), Bilateral agreement between the Federal Republic of Germany and the French Republic, Luxembourg, 27 October 1956, BGBl. 1956 II 1589.

Évian agreements (Les Accords d'Évian), reached between the French government and the Algerian Front de Libération Nationale's Gouvernement Provisoire de la République Algérienne, Évian-les-Bain (France), 18 March 1962, JORF 20 March 1962, 3019.

Agreement between the Republic of Indonesia and the Kingdom of the Netherlands concerning West New Guinea (West Irian), 15 August 1962, UNTS 437, pp. 274-290.

Ratification instrument of the Treaty providing the retrocession by the Spanish State to the Kingdom of Morocco of the territory previously ceded by the latter according to Article 8 of the Treaty of Tétouan [Instrumento de Ratificación del Tratado por el que el Estado Español retrocede al Reino de Marruecos el territorio que éste le había previamente cedido en aplicación del artículo 8 del Tratado de Tetuán de 26 de abril de 1860, firmado en Fez el día 4 de enero de 1969], BOE, n. 134, 5 June 1969.

Protocol annexed to the ratification instrument of the Treaty providing the retrocession by the Spanish State to the Kingdom of Morocco of the territory previously ceded by the latter according to Article 8 of the Treaty of Tétouan [Protocolo anejo al Instrumento de Ratificación del Tratado por el que el Estado Español retrocede al Reino de Marruecos el territorio que éste le había previamente cedido en aplicación del artículo 8 del Tratado de Tetuán de 26 de abril de 1860, firmado en Fez el día 4 de enero de 1969], BOE, n. 134, 5 June 1969.

Agreement between the Kingdom of the Netherlands and the Republic of Surinam concerning the assignment of nationality (Toescheidingsovereenkomst inzake nationaliteiten tussen het Koninkrijk der Nederlanden en de Republiek Suriname), 25 November 1975, UNTS vol. 997, no. 14598.

Treaty on the Unification of Germany (Vertrag zwischen der Bundesrepublik Deutschland und der Deutschen Demokratischen Republik über die Herstellung der Einheit Deutschlands (Einigungsvertrag), BGBl. 1990 II 889, Bulletin (Presse und Informationsamt der Bundesregierung) No. 104/S. 877 (1990), East Berlin, 31 August 1990. 


\section{Other documents}

Inter-American Commission on Human Rights (IACHR), American Declaration of the Rights and Duties of Man, 2 May 1948.

Declaration of Principles on Western Sahara signed between the Spain, Morocco and Mauritania (Declaración de principios entre España, Marruecos y Mauritania sobre el Sáhara Occidental), 14 November 1975, UNTS vol. 988. 


\section{EU law}

Treaty establishing the European Coal and Steel Community, Paris, 18 April 1951 (not published in O).

Treaty establishing the European Economic Community, Rome, 25 March 1957 (not published in OJ).

Treaty between the Kingdom of Belgium, the Federal Republic of Germany, the French Republic, the Italian Republic, the Grand Duchy of Luxembourg, the Kingdom of the Netherlands (Member States of the European Communities), the Kingdom of Denmark, Ireland, the Kingdom of Norway and the United Kingdom of Great Britain and Northern Ireland concerning the accession of the Kingdom of Denmark, Ireland, the Kingdom of Norway and the United Kingdom of Great Britain and Northern Ireland to the European Economic Community and to the European Atomic Energy Community, OJ L (73) 5, 27 April 1972.

Declaration on European Identity, Copenhagen, 14 December 1973, Bulletin of the European Communities, December 1973, No 12. Luxembourg: Office for official publications of the European Communities.

Communiqué issued after the European Summit held in Paris in December 1974, meeting of the Heads of Government, Paris, 9-10 December 1974, Bulletin of the European Communities, December 1974, No 12.

Commission of the European Communities, Towards European Citizenship (lmplementation of point 11 of the final communiqué issued at the European Summit held in Paris on 9 and 10 December 1974), COM (75) 321 final, Brussels, 2 July 1975.

EEC-Algeria Cooperation Agreement, OJ L (263) 2, 26 April 1976.

Resolution on the granting of special rights to be citizens of the European Community in implementation of the decision of the Paris Summit of December 1974 (point 11 of the final communiqué) OJ C (299), 12 December 1977.

Proposal for a Council Directive on a right of residence for nationals of Member States in the territory of another Member State (Submitted by the Commission to the Council on 31 July 1979) COM/79/215FINAL OJ C (207), 17 August 1979. 
European Parliament Resolution on the draft Treaty establishing the European Union (14 February 1984) OJ C (77), 19 March 1984.

Treaty Amending, With Regard to Greenland, the Treaties Establishing the European Communities, OJ L (29) 1, 2 January 1985.

Completing the Internal Market. White Paper from the Commission to the European Council (Milan, 28-29 June 1985), COM (85) 310 final, 14 June 1985.

Council Directive 90/364/EEC of 28 June 1990 on the right of residence OJ L (180), 13 July 1990 (repealed by Directive 2004/38/EC of the European Parliament and of the Council of 29 April 2004 on the right of citizens of the Union and their family members to move and reside freely within the territory of the Member States amending Regulation (EEC) No 1612/68 and repealing Directives 64/221/EEC, 68/360/EEC, 72/194/ EEC, 73/148/EEC, 75/34/EEC, 75/35/EEC, 90/364/EEC, 90/365/EEC and 93/96/EEC).

European Parliament Resolution on Union citizenship 14 June 1991 OJ C (183)473, 15 July 1991.

Declaration no 2 annexed to the Treaty of Maastricht on nationality of a Member State, OJ C (191) 1, 29 July 1992.

European Union, Treaty on European Union (Consolidated Version), Treaty of Maastricht , 7 February 1992, OJ C (191) 1, 29 July 1992.

Declaration on citizenship of the Union, to be associated to the Danish act of ratification of the Treaty on European Union, OJ C (348) 1, 31 December 1992.

Treaty on European Union (Consolidated version), Treaty of Amsterdam, 2 October 1997, OJ C (340), 10 November 1997.

Treaty on European Union (Consolidated version), Treaty of Nice, 26 February 2001, OJ C (80), 10 March 2001.

Council Directive 2001/55/EC of 20 July 2001 on minimum standards for giving temporary protection in the event of a mass influx of displaced persons and on measures promoting a balance of efforts between Member States in receiving such persons and bearing the consequences thereof, $\mathrm{OJ}$ L (212), 7 August 2001. 
Council Directive 2003/9/EC of 27 January 2003 laying down minimum standards for the reception of asylum seekers, OJ L (31), 6 February 2003.

Council Regulation (EC) No 343/2003 of 18 February 2003 establishing the criteria and mechanisms for determining the Member State responsible for examining an asylum application lodged in one of the Member States by a third-country national, OJ L (50), 25 February 2003.

Council Directive 2003/86/EC of 22 September 2003 on the right to family reunification, OJ L (251), 03 October 2003.

Council Directive 2003/109/EC of 25 November 2003 concerning the status of third-country nationals who are long-term residents, OJ L (016) , 23 January 2004.

Directive 2004/38/EC of 29 April 2004 on the right of citizens of the Union and their family members to move and reside freely within the territory of the Member States amending Regulation (EEC) No 1612/68 and repealing Directives 64/221/EEC, 68/360/EEC, 72/194/EEC, 73/148/EEC, 75/34/ EEC, 75/35/EEC, 90/364/EEC, 90/365/EEC and 93/96/EEC, OJ L (158), 30 April 2004.

Council Directive 2004/81/EC of 29 April 2004 on the residence permit issued to third-country nationals who are victims of trafficking in human beings or who have been the subject of an action to facilitate illegal immigration, who cooperate with the competent authorities, OJ L (261), 6 August 2004.

Council Directive 2004/83/EC of 29 April 2004 on minimum standards for the qualification and status of third country nationals or stateless persons as refugees or as persons who otherwise need international protection and the content of the protection granted, OJ L (304), 30 September 2004.

Council Directive 2005/71/EC of 12 October 2005 on a specific procedure for admitting third-country nationals for the purposes of scientific research, OJ L (289), 3 November 2005.

Council Directive 2005/85/EC of 1 December 2005 on minimum standards on procedures in Member States for granting and withdrawing refugee status, OJ L (326), 13 December 2005.

Treaty of Lisbon Amending the Treaty on European Union and the Treaty Establishing the European Community, 13 December 2007, OJ C (306) 01, 17 December 2007. 
Directive 2008/115/EC of 16 December 2008 on common standards and procedures in Member States for returning illegally staying third-country nationals, OJ L (348), 24 December 2008.

Council Directive 2009/50/EC of 25 May 2009 on the conditions of entry and residence of third-country nationals for the purposes of highly qualified employment, OJ L (155), 18 June 2009.

Directive 2009/52/EC of 18 June 2009 providing for minimum standards on sanctions and measures against employers of illegally staying thirdcountry nationals, OJ L (168), 30 June 2009.

EU Council Decision 2010/718/EU of 29 October 2010 amending the status with regard to the European Union of the island of Saint Barthélemy, OJ L (325) 4, 9 December 2010.

Directive 2011/98/EU of 13 December 2011 on a single application procedure for a single permit for third-country nationals to reside and work in the territory of a Member State and on a common set of rights for third-country workers legally residing in a Member State, OJ L (343), 23 December 2011.

Treaty on the Functioning of the European Union (Consolidated Version), OJ C (326) 55, 26 October 2012.

Charter of Fundamental Rights of the European Union, 2010, OJ C (326), 26 October 2012.

Council Directive 2013/61/EU of 17 December 2013 amending Directives 2006/112/EC and 2008/118/EC as regards the French outermost regions and Mayotte in particular, OJ L (353) 5, 28 December 2013.

European Parliament resolution on EU citizenship for sale, 2013/2995(RSP), 16 January 2014.

European Commission, Press Release, Joint Press Statement by the European Commission and the Maltese Authorities on Malta's Individual Investor Programme (IIP), European Commission - MEMO/14/70, 29 January 2014. 


\section{Other EU related documents}

Parliamentary question by Eluned Morgan (PSE), P-0524/04, 12 February 2004, available at http://www.europarl.europa.eu/sides/getDoc. $\underline{\text { do? } \text { type }=W Q \& \text { reference }=P-2004-0524 \& \text { language }=E N}$.

Answer given by Mr Prodi on behalf of the Commission, P-0524/2004, 1 March 2004, available at http://www.europarl.europa.eu/sides/ getAllAnswers.do?reference=P-2004-0524\&language=EN.

Joint answer given by $\mathrm{Mr}$ Barroso on behalf of the Commission, E-007453/2012,28 August 2004, availableathttp://www.europarl.europa. eu/sides/getAllAnswers.do?reference=P-2012-009756\&language=EN.

Parliamentary question by Ramón Tremosa i Balcells (ALDE), E-000395/2012, 23 January 2012, available at http://www.europarl. europa.eu/sides/getDoc.do?pubRef=-//EP//TEXT+WQ+E-2012$\underline{000395+0+D O C+X M L+V 0 / / E N}$.

Parliamentary question by Mara Bizzotto (EFD), E-007453/2012, 25 July 2012, available at http://www.europarl.europa.eu/sides/getDoc. do?pubRef=-//EP//TEXT+WQ+E-2012-007453+0+DOC+XML+V0//EN.

Parliamentary question by Izaskun Bilbao Barandica (ALDE) , Ramon Tremosa i Balcells (ALDE), Salvador Sedó i Alabart (PPE) and Raül Romeva i Rueda (Verts/ALE), E-008133/2012, 17 September 2012, available at http://www.europarl.europa.eu/sides/getDoc.do?pubRef=-//EP// $\mathrm{TEXT}+\mathrm{WQ}+\mathrm{E}-2012-008133+0+\mathrm{DOC}+\mathrm{XML}+\mathrm{V} 0 / / \mathrm{EN}$.

Parliamentary question by David Martín (S\&D), P-009756/12, 25 October 2012, available at http://www.europarl.europa.eu/sides/getDoc. $\underline{\text { do?type }=W Q \& \text { reference }=P-2012-009756 \& \text { language }=E N}$.

Parliamentary question by Gerard Batten (EFD), P-009862/12, 29 October 2012, available at http://www.europarl.europa.eu/sides/getDoc. $\underline{\text { do?type }=W Q \text { \&reference }=P-2012-009862 \text { \&language }=E N}$.

Answer given by Mr Barroso on behalf of the Commission, P-009756/12 and P-009862/12, 3 December 2012, available at http://www.europarl.europa. eu/sides/getAllAnswers.do?reference=E-2012-007453\&language=EN .

Remarks by President of the European Council Herman Van Rompuy, on Catalonia, EUCO 267/13 of 12 November 2013. 
Viviane Reding, "Citizenship must not be up for sale", European Commission, Speech/14/18, 15 January 2014.

Parliamentary question by Santiago Fisas Ayxelà (PPE), E-011776/15, 21 July 2015, available at http://www.europarl.europa.eu/sides/getDoc. do?pubRef=- //EP//TEXT+WQ+E-2015-011776+0+DOC+XML+V0//EN.

Answer given by President Juncker on behalf of the Commission, E-011776/2015, 21 Septiembre 2015, available at http://www. europarl.europa.eu/sides/getAllAnswers.do?reference=E-2015$\underline{011776 \& \text { language }=\mathrm{EN}}$ 


\section{Domestic law}

\section{Belgium}

Belgian Nationality Act, 22 December 1961, Belgian Official Gazette (Belgisch Staatsblad, Moniteur Belge), 8 January 1962.

Loi relative à l'acquisition ou au recouvrement de la nationalité belge pat l'étrangers nés ou domiciliés sur le territoire de la République du Congo ou par les Congolais ayant eu en Belgique leur résidence habituelle/ Wet betreffende de verwerving of herkrijging van de Belgische nationaliteit door de buitenlanders die geboren zijn of hun woonplaats hebben op het grondgebied van de Republiek Congo of door de Congolezen die hun gewone verblijfplaats in België hebben gehad, Moniteur belge/ Belgisch Staatsblad, 8 January 1962.

Code de la nationalité belge/Wetboek van de Belgische nationaliteit, Belgian Official Gazette (Belgisch Staatsblad, Moniteur Belge), 12 July 1984.

\section{Canada}

Constitution Act 1867, as amended by the Constitution Act 1982, 17 April 1982.

An Act to give effect to the requirement for clarity as set out in the opinion of the Supreme Court of Canada in the Quebec Secession Reference, 29 June 2000, S.C. 2000, c. 26.

\section{Congo}

Loi No. 35-61 du 20 juin 1961 portant Code de la nationalité congolaise.

Constitution de la Republique Democratique du Congo du 1 Aout 1964 Cf. Moniteur Congolais (5 année), numéro spécial du 1 août 1964.

\section{France}

Loi no 46-2385 du 27 octobre 1946 sur la composition et l'élection de l'Assemblée de l'Union française, JORF 28 October 1946, 9178 


\section{Malta}

Citizenship (Amendment) Regulations, 2014, L.N. 17 of 2014, Maltese Citizenship Act, CAP. 188.

Individual Investor Programme of the Republic of Malta Regulations, 2014, L.N. 47 of 2014, Maltese Citizenship Act (CAP. 188), B 341.

\section{Slovenia}

Statement of Good Intentions (Izjava o dobrih namenih) Official Gazette of the RS, no. 44/90-I of 1990.

1991 Constitutional Law relating to the Fundamental Constitutional Charter on the Sovereignty and Independence of the Republic of Slovenia (Ustavni zakon za izvedbo Temeljne ustavne listine o samostojnosti in neodvisnosti $R S$ - Official Gazette of the RS no. 1/91-I of 1991).

Citizenship of the Republic of Slovenia Act (Zakon o državljanstvu Republike Slovenije),Official Gazette nos. 1/91-I, 30/91 and 96/2002 of 1991 and 2002.

Aliens Act (Zakon o tujcih) Official Gazette no. 1/91-I of 1991.

\section{Spain}

\section{Legislation}

Código Civil, Royal Decree 24 July 1889, Madrid Official Gazette (Gaceta de Madrid) No. 206, 25 July 1889.

Statute of Autonomy of Catalonia 1932, Generalitat of Catalonia Official Gazette, n. 19, 15 October 1932.

Decree 10 January 1958, by which the general government of the Spanish West Africa is rearranged (Decreto de 10 de enero de 1958 por el que se reorganiza el gobierno general del África occidental española), BOE, n. 12, 14 January 1958.

Law 46/1959, 30 July, on the organisation and legal regime of the African Provinces (Ley 46/1959, de 30 de Julio, sobre organización y regimen jurídico de las Provincias Africanas), BOE, n. 182, 31 July 1959.

Law 8/1961, 19 April, on the organization and the legal regime of the Province of Sahara (Ley 8/1961, de 19 de abril, sobre organización y régimen jurídico de la Provincia de Sahara) BOE, n. 95, 21 April 1961. 
Law 191/1963, 20 December, on the autonomous regime of Equatorial Guinea (Ley 191/1963, de 20 de diciembre, de Bases sobre el regimen autónomo de la Guinea Ecuatorial) BOE, n. 312, 30 December 1963.

Decree 1885/1964, 3 July, adopting the act on the autonomous regime of Equatorial Guinea (Decreto 1885/1964, de 3 de Julio, por el el que se aprueba la ley articulada sobre regimen autonómico de la Guinea Ecuatorial), BOE, n. 161, 6 July 1964.

Decree 2467 /1968, 9 October, granting independence to Equatorial Guinea (Decreto 2467/1968, de 9 de octubre, por el que se concede la independencia a Guinea Ecuatorial), BOE n. 245, 11 October 1968.

Law 40/1975, 19 November, on the decolonisation of the Sahara (Ley 40/1975, de 19 de noviembre, sobre descolonización del Sáhara), BOE, n. 278, 20 November 1975.

Royal Decree 2258/1976, 10 August, on the right to opt for Spanish nationality by Sahrawi people (Real Decreto 2258/1976, de 10 de agosto, sobre opción de la nacionalidad española por parte de los naturales del Sahara), BOE, n. 233, 28 September 1976.

Royal Decree 2987/1977, 28 October, granting Spanish nationality to certain Equatorial Guinean (Real Decreto 2987/1977, de 28 de octubre, sobre concesión de la nacionalidad española a determinados guineanos), BOE, n. 282, 25 November 1977.

Constitution, BOE n. 311, 29 December 1978.

Organic Law 4/1979, 18 December, enacting the Statute of Autonomy of Catalonia, Generalitat of Catalonia Official Gazette, n. 38, 31 December 1979.

Organic Law 6/2006, 20 July, amending the Statute of Autonomy of Catalonia, Generalitat of Catalonia Official Gazette, n. 4680, 20 July 2006.

DGRN Resolution 3o of 28 July 2009, DGRN Resolutions, compilation from 1 June 2009 to 30 September 2009, Ministry of Justice Bulletin (Boletín del Ministerio de Justicia) Madrid, Ministry of Justice, September 2010.

Resolution 479/X of the Parliament of Catalonia by which it was agreed to submit to the Presiding Board of the Congress the draft organic act delegating to the Generalitat of Catalonia the competence to authorise, call and hold a referendum on the political future of Catalonia (Resolución 479/X del Parlamento de Cataluña por la que se acuerda presentar ante 
la mesa del Congreso de los Diputados la proposición de ley orgánica de delegación en la Generalidad de Cataluña de la competencia para autorizar, convocar y celebrar un referéndum sobre el futuro político de Cataluña), Catalan Parliament Official Gazette (Butlletí Oficial del Parlament de Catalunya), 16 January 2013.

Resolution 5/X of the Parliament of Catalonia, adopting the Declaration of sovereignty and right to decide of the people of Catalonia (Resolución 5/X del Parlamento de Cataluña, por la que se aprueba la Declaración de soberanía y del derecho a decidir del pueblo de Cataluña), Catalan Parliament Official Gazette (Butlletí Oficial del Parlament de Catalunya), 23 January 2013.

Decree 113/2013, 12 February 2013, on the creation of the Advisory Council for the National Transition (Decret 113/2013, de 12 de febrer, de creació del Consell Assessor per a la Transició Nacional), Catalan government Official Gazette (Diari Oficial de la Generalitat de Catalunya), No. 6315, 14 February 2013.

Resolution 479/X of the Parliament of Catalonia by which it was agreed to submit to the Presiding Board of the Congress the draft organic act delegating to the Generalitat of Catalonia the competence to authorise, call and hold a referendum on the political future of Catalonia (Resolución 479/X del Parlamento de Cataluña por la que se acuerda presentar ante la mesa del Congreso de los Diputados la proposición de ley orgánica de delegación en la Generalidad de Cataluña de la competencia para autorizar, convocar y celebrar un referéndum sobre el futuro político de Cataluña), Catalan Parliament Official Gazette, 16 January 2014.

Decree 71/2014, 27 May, creating the Registry of Catalans living abroad and establishing the requirements and procedures for registration, Catalan government Official Gazette (Diari Oficial de la Generalitat de Catalunya), No. 6635, 2 June 2014.

DGRN Resolution $92^{\circ}$ of 31 July 2014, DGRN Resolutions, compilation from 1 July 2014 to 30 July 2014, Ministry of Justice Bulletin (Boletín del Ministerio de Justicia) Madrid, Ministry of Justice, April 2015.

Law 10/2014, 26 September, on popular non-referendum consultations and civic participation (Ley 10/2014, de 26 de septiembre, de consultas populares no refrendarias y otras formas de participación ciudadana), Generalitat of Catalonia Official Gazette (Diari Oficial de la Generalitat de Catalunya), n. 6715, 27 September 2014. 
Decree 129/2014, 27 September, calling the non referendum and civic consultation on political future of Catalonia (Decreto 129/2014, de 27 de septiembre, de convocatoria de la consulta popular no referendaria sobre el futuro político de Cataluña), Generalitat of Catalonia Official Gazette, n. 6715, 27 September 2014.

Decree 132/2014, 2 October, appointing members of Control Commission on non referendum and civic consultation (Decreto 132/2014, de 2 de octubre, de nombramiento de los miembros de la Comisión de Control de las Consultas Populares no Refrendarias), Generalitat of Catalonia Official Gazette, n. 6720A, 3 October 2014.

DGRN Resolution 40 of 8 May 2015, DGRN Resolutions, compilation from 1 May 2015 to 31 May 2015, Ministry of Justice Bulletin (Boletín del Ministerio de Justicia) Madrid, Ministry of Justice, November 2015.

Decree 174/2015, 3 August, calling elections to the Catalan Parliament and its dissolution (Decreto 174/2015, de 3 de agosto, de convocatoria de elecciones al Parlamento de Cataluña y de su disolución), BOE, n. 185, 4 August 2015.

Motion for resolution on the beginning of a political process in Catalonia linked to the results of the elections (Proposta de resolució sobre l'inici del procés polític a Catalunya com a conseqüència dels resultats electorals), Catalan Parliament Official Gazette (Butlletí Oficial del Parlament de Catalunya), 27 October 2015.

Resolution 1 / XI of the Parliament of Catalonia, on the beginning of a political process in Catalonia linked to the results of the 27 September 2015 elections (Resolució 1/XI del Parlament de Catalunya, sobre l'inici del process polític a Catalunya com a conseqüència dels resultats electorals del 27 de setembre de 2015), Catalan Parliament Official Gazette (Butlletí Oficial del Parlament de Catalunya), 9 November 2015.

Decree 2/2016, 13 January, on the creation, designation and determination of the scope of competence of the government departments of the Generalitat of Catalonia (Decret 2/2016, de 13 de gener, de creació, denominació i determinació de l'àmbit de competència dels departaments de l'Administració de la Generalitat de Catalunya), Generalitat of Catalonia Official Gazette, n. 7037, 14 January 2016.

Decree 212/2016, 1 March, adding a transitory provision to the Decree 2/2016, 13 January, on the creation, designation and determination of the scope of competence of the government departments of the Generalitat of Catalonia (Decret 212/2016, d'1 de març, pel qual s'afegeix una disposició 
transitòria al Decret 2/2016, de 13 de gener, de creació, denominació i determinació de l'àmbit de competència dels departaments de l'Administració de la Generalitat de Catalunya), Generalitat of Catalonia Official Gazette, n. 7073, 7 March 2016.

Resolution 5/XI of the Parliament of Catalonia creating parliamentary commissions (Resolució 5/XI del Parlament de Catalunya, de creació de comissions parlamentàries), Catalan Parliament Official Gazette (Butlletí Oficial del Parlament de Catalunya), 25 January 2016.

Resolution 263/XI of the Parliament of Catalonia endorsing the report and the conclusions of the Commission to Study the Constituent Process (Resolució 263/XI del Parlament de Catalunya, per la qual es ratifiquen l'Informe i les Conclusions de la Comissió d'Estudi del Procés Constituent), Catalan Parliament Official Gazette (Butlletí Oficial del Parlament de Catalunya), 1 August 2016.

Resolution 306/XI of the Parliament of Catalonia on the general political orientation of the Government of Catalonia (Resolució 306/XI del Parlament de Catalunya, sobre l'orientació política general del Govern), Catalan Parliament Official Gazette (Butlletí Oficial del Parlament de Catalunya), 18 October 2016.

\section{Other documents}

Catalan Council for Statutary Guarantees (Consell de Garanties Estatutàries de Catalunya/ Consejo de Garantías Estatutarias de Cataluña), Opinion $15 / 2010$ regarding the proposal for consultation by way of referendum on the independence of the Catalan nation (Dictamen 15/2010 respecte a la Proposta de consulta popular per via de referèndum sobre la independència de la nació catalane), 6 July 2010.

Institute of Autonomic Studies of Barcelona, 'Report on legal procedures by which the citizens of Catalonia can be viewed on their collective political future' [Informe sobre els procediments legals a traves dels quals els ciutadans i les ciutadanes de Catalunya poden ser consultats sobre llur futur politic collectiu], 11 March 2013. Available at http://www20.gencat. cat/docs/governacio/IEA/documents/Dret $\% 20 a \% 20$ decidir/Arxius/ Informe\%20consultes CAT.pdf.

Advisory Council for the National Transition, "The consultation on the political future of Catalonia", report n. 1, July 2013. Available at http:// presidencia.gencat.cat/web/.content/ambits actuacio/consells assessors/catn/informes publicats/inf 1 angles.pdf. 
Catalan Council for Statutory Guarantees, Opinion 19/2014 on the draft law on popular non-referendum consultations and civic participation (Dictamen del Consell de Garanties Estatutàries 19/2014 sobre la Proposició de llei de consultes populars no referendàries i d'altres formes de participació ciutadana), 19 August 2014.

Generalitat de Catalunya, Pla de Ciutadania i de les Migracions: horitzó 2016 (September 2014) available at: http://www20.gencat.cat/docs/ bsf/03Ambits\%20tematics/05Immigracio/03Politiquesplansactuacio/ pla ciutadania immmigracio/PCM 2013-2016.pdf.

Advisory Council for the National Transition, "Paths for Catalonia's integration in the European", report n. 6, October 2014. Available at http://presidencia.gencat.cat/web/.content/ambits_actuacio/consells assessors/catn/informes publicats/inf 6 angles.pdf.

Advisory Council for the National Transition, "The constitutional process", Report No. 10, October 2014. Available at http://presidencia.gencat. cat/web/.content/ambits_actuacio/consells_assessors/catn/informes publicats/inf 10 castella.pdf.

Permanent Commission of the State Council, dossier n. 1092/2014, Opinion establishing the challenge before the Constitutional Court of the actions of the Government of Catalonia for calling the Catalans and Catalan residents to express their views on the political future of Catalonia the day November 9 through a so-called citizen participation process (Propuesta de Acuerdo por el que se plantea impugnación ante el Tribunal Constitucional en relación con las actuaciones de la Generalidad de Cataluña relativas a la convocatoria a los catalanes, las catalanas y las personas residentes en Cataluña para que manifiesten su opinión sobre el futuro político de Cataluña el dia 9 de noviembre mediante un denominado "proceso de participación ciudadana), 30 October 2014.

Report of Commission to Study the Constituent Process (Informe de la Comissió d'Estudi del Procés Constituent), Catalan Parliament Official Gazette (Butlletí Oficial del Parlament de Catalunya), 20 July 2016.

\section{United Kingdom}

\section{Legislation}

Union with Scotland Act, 1706, 6 Ann., c 11.

Union with Ireland Act 1800. 
British Nationality and Status of Aliens Act 1914, 1914 Chapter 17, 7 August 1914.

Act to make provision for, and in connection with, the attainment by the Gold Coast of fully responsible status within the British Commonwealth of Nations, 7 February 1957.

Act to make provision for, and in connection with, the establishment of an independent republic in Cyprus, 29 July 1960.

Act to make provision for, and in connection with, the attainment by Nigeria of fully responsible status within the Commonwealth, 29 July 1960.

Act to make provision for, and in connection with, the attainment by Jamaica of fully responsible status within the Commonwealth, 19 July 1962.

Act to make provision for, and in connection with, the attainment by Uganda of fully responsible status within the Commonwealth, 1 August 1962.

Act to make provision for, and in connection with, the attainment by Trinidad and Tobago of fully responsible status within the Commonwealth, 1 August 1962.

Act to make provision for and in connection with the federation of North Borneo, Sarawak and Singapore with the existing States of the Federation of Malaya, 31 July 1963.

Act to make provision for, and in connection with, the attainment by Kenya of fully responsible status within the Commonwealth, including provision for terminating the giving of financial and other assistance to the East African Common Services Organisation under the Colonial Development and Welfare Act 1959, 3 December 1963.

Act to make provision for and in connection with the attainment by Nyasaland of fully responsible status within the Commonwealth, 10 June 1964.

Act to make provision for, and in connection with, the establishment of Northern Rhodesia, under the name of Zambia, as an independent republic within the Commonwealth, 31 July 1964.

Act to make provision for, and in connection with, the attainment by Malta of fully responsible status within the Commonwealth, 31 July 1964. 
Act to make provision for, and in connection with, the attainment by The Gambia of fully responsible status within the Commonwealth, 17 December 1964.

Act to provide for the attainment by British Guiana of fully responsible status within the Commonwealth; to make provision as to the effect of certain certificates of naturalisation; and for purposes connected with the matters aforesaid, 12 May 1966.

Act to make provision for, and in connection with, the establishment of the Bechuanaland Protectorate, under the name of Botswana, as an independent republic within the Commonwealth, 3 August 1966.

Act to make provision for, and in connection with, the establishment of Basutoland, under the name of Lesotho, as an independent kingdom within the Commonwealth, 3 August 1966.

Act to make provision for, and in connection with, the attainment by Barbados of fully responsible status within the Commonwealth, 17 November 1966.

British Nationality Act 1981, 1981 Chapter 61, 30 October 1981.

Scotland Act, 1998.

Agreement between the United Kingdom Government and the Scottish Governement on a referendum on independence of Scotland, Edinburgh, 15 October 2012.

Scottish Independence Referendum (Franchise) Act 2013, 27 June 2013.

Bill to make provision for the holding of a referendum in the United Kingdom and Gibraltar on whether the United Kingdom should remain a member of the European Union, 14 December 2015.

European Union (Notification of Withdrawal) Act 2017, 16 March 2017.

\section{Other documents}

A Draft Constitution for an Independent Scotland, Scottish Provisional Constituent Assembly, 1957-1964.

The Parliament and Constitution of an Independent Scotland, February 1997, SNP. 
A Constitution for a Free Scotland, SNP policy paper, September 2002.

Scottish government, Scotland's Future: Your Guide to an Independent Scotland, 2013.

Scotland's Future: Your Guide to an Independent Scotland, Scottish Government, November 2013.

Conservative Party, Strong Leadership, a clear economic plan, a brighter, more secure future: The Conservative Party manifesto 2015.

Scotland's Place in Europe, Scottish Government, December 2016.

Consultation on a Draft Referendum Bill, Scottish Government, October 2016.

The United Kingdom's exit from and new partnership with the European Union, United Kingdom Government, February 2017. 


\section{Case law}

PCIJ

Advisory Opinion No. 4, Nationality Decrees Issued in Tunis and Morocco, 4, Permanent Court of International Justice, 7 February 1923.

\section{ICJ}

Liechtenstein v Guatemala ("Re Nottebohm") [1955] International Court of Justice, Reports 4.

Western Sahara, Advisory Opinion, ICJ GL No 61, [1975] ICJ Rep 12, ICGJ 214 (ICJ 1975), 16th October 1975, International Court of Justice.

Application of the Convention on the Prevention and Punishment of the Crime of Genocide (Bosnia and Herzegovina v Yugoslavia), Preliminary Objections, 1996, ICJ Reports.

Separate Opinion of Judge Shahabuddeen, Application of the Convention on the Prevention and Punishment of the Crime of Genocide (Bosnia and Herzegovina v Yugoslavia), Preliminary Objections, 1996, ICJ Reports.

Separate Opinion of Judge Weeramantry, Application of the Convention on the Prevention and Punishment of the Crime of Genocide (Bosnia and Herzegovina v Yugoslavia), Preliminary Objections, 1996, ICJ Reports.

Separate Opinion of Judge Parra-Aranguren, Application of the Convention on the Prevention and Punishment of the Crime of Genocide (Bosnia and Herzegovina v Yugoslavia), Preliminary Objections, 1996, ICJ Reports.

Accordance with International Law of the Unilateral Declaration of Independence in Respect of Kosovo (Request for Advisory Opinion), General List No. 141, International Court of Justice (ICJ), 22 July 2010. 
EU

Case C-369/90, Micheletti [1992] ECR I-04239.

Opinion of Advocate General Léger, in Case C-192/99, Kaur [2000] ECR I-01239.

Case C-192/99, Kaur [2001] ECR I-01237.

Opinion of Advocate General Tizzano, in Case C-200/02, Zhu and Chen [2004] ECR I-09951.

Case C-200/02, Zhu and Chen [2004] ECR I-09951.

Case C-145/04, Spain v United Kingdom [2006] ECR I-07961.

Case C-300/04, Eman and Sevinger [2006] ECR I-08055.

Opinion of Advocate General Maduro, in Case C-135/08, Rottmann [2010] ECR I-01449.

Case C-135/08, Rottmann [2010] ECR I-01449.

Case C 34/09, Ruiz Zambrano [2011] ECR I-01177.

\section{ECtHR}

Case Matthews v United Kingdom, Application No. 24883/94, 18 February 1999.

Case Bijelic v Montenegro and Serbia, Application No. 19890/05, 11 June 2009.

Case Kurić and Others v Slovenia, Application No. 26828/06, 13 July 2010.

Case Kurić and Others v Slovenia, Application No. 26828/06, 26 June 2012.

\section{Inter-American Court of Human Rights}

Advisory Opinion on Proposed Amendments to the Naturalization Provision of the Constitution of Costa Rica, OC-4/84, Inter-American Court of Human Rights, 19 January 1984. 


\section{International Criminal Tribunal in relation to the former Yugoslavia}

Prosecutor v Delalic et al 'Judgment' (Appeals Chamber), 20 February 2001, Case IT-96-21 (ICTY).

\section{Domestic courts}

Canada

Reference re Secession of Quebec, [1998] 2 S.C.R. 217.

Germany

Bundesverwaltungsgericht 11 November 2010, Case 5 C12.10.

\section{Spain}

Constitutional Court:

STC 31/2010, 28 June, BOE, n. 172, 16 July 2010.

Constitutional Court resolution (Providencia), 7 May 2013, BOE, n. 112, 10 May 2013.

STC 42/2014, 25 March, BOE, n. 87, 10 April 2014.

STC 31/2015, 25 February, BOE, n. 64, 16 March 2015.

STC 32/2015, 25 February, BOE, n. 64, 16 March 2015.

STC 138/2015, 11 June, BOE, n. 160, 6 July 2015.

STC 259/2015, 2 December, BOE, n. 10, 12 January 2016.

Constitutional Court decision (Providencia), 16 February 2016, BOE, n. 43, 19 February 2016.

Auto 130/2016, 21 June, BOE, n. 158, 1 July 2016.

Auto 141/2016, 19 July, BOE, n. 196, 15 August 2016. 
Auto 170/2016, 6 October, BOE, n. 276, 15 November 2016.

Constitutional Court decision (Providencia), 13 December 2016, BOE, n. 302, 15 December 2016.

Supreme Court:

STS 6268/1998, Section 1, 28 October 1998.

STS 4276/2012, Section 4, 12 June 2012.

Supreme Court decision 10383/2014 (Auto), 6 November 2014, Administrative Chamber n. 7.

Slovenia

Decision of the Slovenian Constitutional Court, 4 February 1999 (U-I284/94).

\section{United Kingdom}

R (Miller) -v- Secretary of State for Exiting the European Union, Case No. CO/3809/2016 and CO/3281/2016, 3 November 2016.

R (on the application of Miller and another) (Respondents) $v$ Secretary of State for Exiting the European Union (Appellant), reference by the Attorney General for Northern Ireland - In the matter of an application by Agnew and others for Judicial Review reference by the Court of Appeal (Northern Ireland) - In the matter of an application by Raymond McCord for Judicial Review, UKSC 2016/0196, 24 January 2017. 


\section{Summary}

An eventual independence of Catalonia, Scotland or Flanders would undoubtedly be a unique event. The uniqueness of this situation is demonstrated not only by the fact that it would be the first case of the breakup of an EU Member State, but also due to the effects of the hypothetical independence of a devolved part of an EU Member State on the nationality of persons and their status as citizens of the Union. These effects raise novel legal issues that cannot be addressed from the perspective of one sole legal order.

From a Public International Law perspective, a Catalan, Scottish or Flemish independence would amount to a case of State succession. Within the framework of Public International Law, questions related, inter alia, to the right to self-determination, statehood, rules applicable to nationality matters arising in State succession context and States' membership of international organisations need to be assessed. However, Public International Law is not holistic enough to address the challenges posed by a hypothetical independence of a devolved part of an EU Member State. Nationality matters arising in this context are far from simple, and given the link between nationality and EU citizenship, the picture becomes even more complicated.

In the context of State succession, the new State has to determine who its nationals will be. The predecessor State has to decide whether or not the acquisition of the nationality of the newly independent State will entail losing the nationality of the predecessor State. The link between the nationality of the predecessor State and the status of citizenship of the Union adds a European dimension to this issue. Moreover, historical experiences have shown, that when drafting the rules on the acquisition of nationality of the newly independent State and the loss of the nationality of the predecessor State, then States should act in such a way that avoids not only statelessness situations but also unnecessary migration flows.

At the heart of this situation are the people affected by the eventual independence of the regions at stake. These people, by the operation of the hypothetical State succession, could witness a change of their status as nationals of an EU Member State and, therefore, citizens of the Union or, more generally, a change of the legal framework applicable to the territory where they have been residing under the umbrella of EU law. They could find themselves in a position where strategic decisions have to be made 
in order to retain a certain status under EU law or in order to guarantee the continuation of certain residence rights. These strategic decisions must also be taken in the new scenario posed by "Brexit". More specifically, the situations of nationals from the seceding regions, who reside in the new States and in the territory of other EU Member States; and European citizens and third country nationals residing in the seceding territories needs to be analysed.

This thesis adopts a multidimensional approach, taking into account three different yet intertwined legal orders: Public International Law, domestic nationality law and European Law. Public International Law guides the study of statehood, State succession, nationality matters arising in State succession scenarios, membership of international organisations and automatic accession to human right treaties.

It is concluded that the presumption of automatic membership to the EU of the newly independent States seems rather speculative in light of international law and the practice of international organisations. Theories supporting the automatic accession (accession from within/internal enlargement) of these regions to the EU are not realistic. An interim period between independence and accession to the EU will, in principle, exist. Consequently, the newly independent State is no longer a Member State of the EU and EU law is not applicable on the territory of that new State on the date of its independence.

That being so, it is for the predecessor EU Member State and the successor non-EU Member State to determine the nationality rules that need to be enacted upon independence. International law imposes certain restrictions on this power (such as the avoidance of statelessness), but so too does EU law. The predecessor State, that still retains its membership of the EU, has to take into account EU law when determining the rules in respect of loss of nationality by nationals acquiring the nationality of the newly independent State. Furthermore, if the new State aspires to become a Member State of the EU, it should regulate its nationality law in such a way that is acceptable for the EU in view of future accession negotiations.

In this context, particular attention must be paid to the nationality position of minors and third country nationals. A complicating element to be considered is that in Catalonia and in Scotland, minors who reached the age of 16 were eligible to participate in the independence queries that were held in those regions.

Although the referendum itself does not entail the independence of a certain region, it constitutes the first step to trigger an independence process that would have effects on the nationality status of the people 
residing in the secessionist territory, including third country nationals. There is no obligation on behalf of the newly independent States to extend an offer of nationality to migrants. However, for individuals, and especially migrants, a vote in the referendum or consultation must be an informed one, and a lack of understanding as to who would be citizens after any vote is not acceptable. A proposal on nationality policy should be provided before independence, or ideally, before the referendum takes place.

Whereas the new State will not be immediately become a Member State of the EU and bound by EU law, the situation differs in respect of the obligations flowing from the ECHR, in particular the right to private and family life. The three States which have been studied in the present research are members of the Council of Europe and are bound by the ECHR. Furthermore, the potential newly independent States will also become members of the Council of Europe. It is necessary to consider the possible application of the doctrine on the automatic State succession to treaties dealing with fundamental human rights. Following the jurisprudence of the ECtHR in the Kurić decision, whose relevance in the context of the Scottish independence referendum was first highlighted by Vidmar, this doctrine will be applicable in the case of the eventual independence of Catalonia, Flanders or Scotland, even if those territories do not automatically apply the ECHR.

In the scenario of an eventual independence of Catalonia, Flanders or Scotland, following the thesis developed by Vidmar, the residence rights of certain categories of people residing in the territory of the potential newly independent State, in the predecessor States or in other EU Member States are protected. However, that protection is limited to the residence rights enjoyed at the moment of independence and within the territory in which that residence has been established. Accordingly, it seems more appropriate, following Vidmar's idiolect, to refer to a set of rights that are being "frozen", especially when this protection is territorially restricted. The right to remain in the territory of the newly independent State, the predecessor State or other EU Member State shall be ensured in any case by the application of the Kuric formula. Ideally, nationals of the newly independent States residing in the predecessor State or other EU Member States, nationals of the predecessor State (or other EU Member States) residing in the newly independent States and TCNs residing in the new States will have their residence rights protected. From a practical day-today perspective, their position should not change and their right to private and family life, which is strictly linked to their residence status, has to be respected.

Civis europaeus sum? This question has been the cornerstone of this thesis. Besides all the complex legal issues arising around an eventual 
State succession within an EU Member State, this is the question that people affected by that situation need an answer to. The link between the nationality of an EU Member State and citizenship of the Union is, as it stands now, unbreakable. One cannot claim the enjoyment of the latter without holding the nationality of an EU Member State. Thus, those who, due to the operation of the State succession and the rules enacted in that context regarding nationality, lose the nationality of the predecessor-EU Member State cannot invoke 'civis europaeus sum'. From the outset, individuals who lose the nationality of a Member State would lose EU citizenship and the rights associated to it. However, although EU citizenship is still not autonomous from Member State nationality, it is possible to agree with Vidmar that certain rights associated to the residence in both the potential newly independent States and the EU Member States will be frozen as, an interim solution, until the former completes the EU accession process.

The role of EU citizenship in this scenario cannot be overemphasised. Given the state of affairs, citizenship of the Union is not enough, at least from the legal perspective, to defend the automatic accession of the potential newly independent States. These new States cannot circumvent the accession procedure to the EU. Notwithstanding, EU citizenship has a role to play through the influence of EU law on the nationality law of the remaining EU Member States and, especially, the application of the proportionality principle in decisions on loss of nationality. 


\section{Resumen}

Civis europaeus sum? Independencia de parte de un Estado miembro de la UE y sus consecuencias para la nacionalidad y el estatus de ciudadano de la Unión.

La posible independencia de Cataluña, Escocia o Flandes constituiría, en caso de producirse, un evento sin precedentes en la Unión Europea. Lo novedoso de dicha situación vendría dado no sólo por el hecho en sí de la ruptura de un Estado miembro, sino por las consecuencias de la misma sobre la nacionalidad y el estatus de ciudadano de la Unión de las personas afectadas por ese posible proceso independentista.

La independencia de Cataluña, Escocia o Flandes se encuadraría en la categoría de la sucesión de Estados. Y es dentro del ámbito del Derecho Internacional Público en el que es necesario abordar cuestiones relativas a la creación de los Estados, el derecho a la libre determinación de los pueblos, la nacionalidad de las personas físicas en el marco de la sucesión de Estados o la adquisición de la condición de Estado miembro en organizaciones internacionales. Sin embargo, esta disciplina jurídica, el Derecho Internacional Público, resulta insuficiente para dar respuestas a los retos que plantea una hipotética independencia de parte de un Estado miembro de la UE. Las cuestiones relacionadas con la nacionalidad de las personas físicas y la sucesión de Estados, ya complejas de por sí, adquieren mayor complejidad cuando el vínculo entre nacionalidad y ciudadanía de la UE entra en juego.

En ese contexto de la sucesión de Estados, el nuevo Estado tiene que determinar quiénes serán sus nacionales. Por su parte, el Estado predecesor, en aquellos supuestos en que siga existiendo, tiene que decidir sila adquisición de la nacionalidad del nuevo Estado por parte de sus nacionales implicará la pérdida de su nacionalidad. El vínculo entre la nacionalidad del Estado predecesor y la ciudadanía de la Unión añade una dimensión europea a esta cuestión. Además, las normas relativas a la adquisición de la nacionalidad del nuevo Estado y la pérdida de la nacionalidad del Estado predecesor han de ser redactadas de forma tal que se eviten, no sólo situaciones de apatridia, sino también innecesarios movimientos migratorios.

En el centro de este complejo proceso se encuentran personas que pueden verse afectadas por la eventual independencia de la región en la que viven o de la que provienen. Estas personas podrían experimentar cambios en 
su condición de nacionales de un Estado miembro de la UE y, por tanto, de ciudadanos de la Unión o, de forma general, presenciar una modificación del marco jurídico aplicable al territorio en el que han venido residiendo. En este escenario, se han de tomar decisiones estratégicas con el fin de mantener un cierto estatus o de garantizar la continuidad de ciertos derechos de residencia, decisiones éstas que se plantean también en el marco del "Brexit". Especial atención se presta a la situación de los nacionales de los posibles nuevos Estados que residen en los mismos o en el territorio de Estados miembros de la UE; así como de los ciudadanos europeos y nacionales de terceros países que residen en los territorios de los nuevos Estados.

Tres órdenes legales se entrelazan en la presente investigación doctoral: Derecho Internacional Público, Derecho Europeo (Derecho de la Unión Europea y del Consejo de Europa) y normas internas (de cada Estado) en materia de nacionalidad. El Derecho Internacional Público guía el estudio de la creación de los Estados, la sucesión de Estados, las cuestiones de nacionalidad que se plantean en la sucesión de Estados, la membresía a organizaciones internacionales y la aplicación automática de tratados sobre derechos humanos.

A la luz del derecho internacional y, especialmente, de la práctica de las organizaciones internacionales, se concluye que la adhesión automática a la UE de los nuevos Estados tiene carácter más bien especulativo. Las teorías que apoyan la adhesión automática de estas regiones no tienen fundamento legal. La existencia de un período de transición entre la independencia y la adhesión a la UE es, en principio, necesaria y, consecuentemente, durante dicho periodo, el nuevo Estado no sería un Estado miembro de la UE y el derecho de la UE no sería aplicable en su territorio.

Siendo esto así, en el momento de la eventual independencia de parte de un Estado miembro de la UE, el nuevo Estado, no miembro de la UE $a b$ initio, ha de promulgar la legislación pertinente en materia de nacionalidad. Igualmente, es de esperar que el Estado predecesor, miembro de la UE, realice las modificaciones legislativas oportunas en materia de nacionalidad que reflejen la nueva realidad. Sin embargo, existen ciertas restricciones a esta potestad de ambos Estados, impuestas no sólo por el derecho internacional (como la prevención de la apatridia), pero también por la legislación de la UE. El Estado predecesor, que aún conserva su condición de miembro de la UE, ha de tener en cuenta el derecho de la UE a la hora de regular la pérdida de su nacionalidad como consecuencia de la adquisición la nacionalidad del nuevo Estado. Por otra parte, si el nuevo Estado aspira a convertirse en un Estado miembro de la UE, y de cara a las futuras negociaciones de adhesión, su legislación sobre nacionalidad no ha de ser contraria a los principios del Derecho de la UE. 
Especial atención merece la posición de los menores y de los nacionales de terceros países en este contexto. Tanto en el referéndum escocés como en el proceso participativo catalán, los menores que hubieran alcanzado la edad de 16 años pudieron emitir su voto.

Si bien es cierto que un referéndum, en sí mismo, no supone la independencia automática de la región en la que se celebra, sí que constituye el primer paso en el proceso que podría desembocar en esa independencia, con los efectos que ello conllevaría para la nacionalidad de las personas que residen en el territorio secesionista, incluidos los nacionales de terceros países. No existe obligación alguna por parte de los nuevos Estados independientes de conceder su nacionalidad a nacionales de terceros países. Sin embargo, para la población de estas regiones y, especialmente para los inmigrantes, el acto de votar en un referéndum o consulta debe ser un acto informado y la falta de información sobre las reglas aplicables para la concesión de nacionalidad de ese posible nuevo Estado no es aceptable. Las propuestas legislativas en materia de concesión de nacionalidad deben darse a conocer antes de que la independencia de la región se produzca o, incluso mejor, antes de que la consulta independentista se lleve a cabo.

Como ya se ha indicado, el nuevo Estado no será de forma automática Estado miembro de la UE y, por lo tanto, no tendrá la obligación de aplicar el Derecho de la UE. No obstante, la situación es distinta en relación con las obligaciones derivadas de la CEDH y, específicamente, del derecho al respeto de la vida privada y familiar. España, Bélgica y Reino Unido, los tres Estados objeto de estudio en la presente investigación doctoral, son miembros del Consejo de Europa. Por su parte, es lógico pensar que los posibles nuevos Estados se convertirán igualmente en miembros del Consejo de Europa. Sin embargo, incluso antes de la membresía al Consejo de Europa, la CEDH podría ser automáticamente aplicable en el territorio de los nuevos países, siguiendo la teoría de la sucesión automática en tratados relativos a derechos humanos fundamentales. Siguiendo la jurisprudencia del TEDH y, concretamente, la doctrina emanada en el asunto Kurić (cuya relevancia en el marco del referéndum sobre la independencia de Escocia fue ya apuntada por Vidmar) sería aplicable en el caso de la eventual independencia de Cataluña, Flandes o Escocia, incluso si estos territorios no hubieran accedido al Consejo de Europa.

De esta forma, en el escenario de una eventual independencia de Cataluña, Flandes o Escocia, siguiendo la tesis desarrollada por Vidmar, los derechos de residencia de ciertas categorías de personas que residan en el territorio de los nuevos Estados, en los Estados predecesores o en Estados miembros de la UE estarían protegidos. Esta protección, sin embargo, se limita a los derechos de residencia tal y como se venían disfrutando en el momento de la independencia y en el territorio en el que dicha residencia se hubiera 
establecido. Consecuentemente, y debido a esa limitación territorial, parece más apropiado, adoptando la terminología de Vidmar, referirse a la "congelación" de los derechos de residencia. El derecho a permanecer en el territorio del nuevo Estado, del Estado predecesor o de un Estado miembro de la UE quedaría garantizado, en todo caso, por la aplicación de la doctrina emanada en el asunto Kurić. Así, los nacionales de los nuevos Estados que residan en el Estado predecesor o en otros Estados miembros de la UE, los nacionales del Estado predecesor (o de otros Estados miembros de la UE) que residan en los nuevos Estados y los nacionales de terceros países que residan en los nuevos Estados se beneficiarían de la protección de sus derechos de residencia. Su vida cotidiana, en principio, no debe verse afectada y su derecho a la vida privada y familiar, que está estrictamente ligada a su residencia, tiene que ser respetado.

Civis europaeus sum? Esta cuestión constituye la piedra angular de esta tesis. Más allá de las complejas cuestiones legales en torno a una eventual sucesión de Estados dentro de un Estado miembro de la UE, esta es la pregunta que las personas afectadas por esa situación necesitan que sea respondida. El vínculo entre la nacionalidad de un Estado miembro de la UE y la ciudadanía de la Unión es, por ahora, indestructible. Nadie puede disfrutar del estatus de ciudadano europeo sin tener la nacionalidad de un Estado miembro de la UE. Por lo tanto, aquellos que, debido a la operación de la sucesión de Estados y las normas en materia de nacionalidad promulgadas en ese contexto, pierdan la nacionalidad del Estado predecesor y miembro de la UE no pueden invocar civis europaeus sum. Las personas que pierdan la nacionalidad de un Estado miembro de la UE perderían la ciudadanía de la Unión y los derechos asociados a ella. A pesar de que la ciudadanía de la UE está inevitablemente vinculada a la nacionalidad de los Estados miembros, ciertos derechos asociados a la residencia, tanto en los potenciales nuevos Estados como en los Estados miembros de la UE, pueden congelarse, como ha apuntado Vidmar, siendo ésta una solución provisional hasta que el nuevo Estado complete el proceso de adhesión a la UE.

El papel de la ciudadanía de la UE en este escenario, si bien importante, no debe sobrestimarse. La ciudadanía de la Unión no es suficiente, al menos desde el punto de vista jurídico, para defender la adhesión automática de los potenciales nuevos Estados. Estos nuevos Estados no pueden eludir el procedimiento de adhesión a la UE. No obstante, la ciudadanía de la UE está llamada a desempeñar una importante función en este escenario, pudiendo influenciar y condicionar las decisiones legislativas en materia de nacionalidad del Estado predecesor y miembro de la UE y, en especial, a mediante la aplicación del principio de proporcionalidad en las decisiones sobre pérdida de nacionalidad. 


\section{Samenvatting}

Civis europaeus sum? De onafhankelijkheid van een deel van een Lid-Staat van de Europese Unie en haar gevolgen voor het nationaliteitsrecht en het Europese burgerschap.

De eventuele onafhankelijkheid van Catalonië, Schotland of Vlaanderen zou een unieke gebeurtenis zijn. Het unieke karakter van een dergelijke gebeurtenis vloeit niet slechts voort uit het feit, dat het de eerste keer zou zijn dat een Lid-Staat van de Europese Unie uiteenvalt, maar ook vanwege de gevolgen van een dergelijke hypothetische onafhankelijkheid van een deel van een EU Lid-Staat voor de nationaliteit van personen en hun burgerschap van de Europese Unie. Deze gevolgen werpen nieuwe juridische problemen op die niet slechts vanuit het perspectief van een enkele rechtsorde kunnen worden behandeld.

Vanuit het prespectief van internationaal publiekrecht zou een Catalaanse, Schotse of Vlaamse onafhankelijkheid een geval van statenopvolging zijn. Daarom moeten binnen het kader van internationaal publiekrecht ondermeer vragen met betrekking tot het zelfbeschikkingsrecht, criteria voor het zijn van Staat, regels met betrekking tot de nationaliteit in geval van statenopvolging en het lidmaatschap van internationale organisaties worden behandeld. Maar het internationaal publiekrecht is niet voldoende holistisch om alle aspecten van de uitdagingen veroorzaakt door de hypothetische onafhankelijkheid van een deel van een Lid-Staat van de EU te doorgronden. Nationaliteitsrechtelijke vragen die opkomen in de context van statenopvolging zijn verre van eenvoudig en de relatie tussen nationaliteit en het Europese burgerschap maakt deze nog gecompliceerder.

In geval van statenopvolging moet de nieuwe Staat bepalen wie zijn burgers zullen zijn. De voorgangerstaat moet beslissen of de verwerving van de nationaliteit van de nieuwe onafhankelijke Staat al dan niet het verlies van de nationaliteit van die voorgangerstaat bewerkstelligt. De relatie tussen de nationaliteit van de voorgangerstaat en de status van Europees burger voegt een Europese dimensie aan deze problematiek toe. Bovendien tonen historische ervaringen aan, dat Staten er goed aan doen om de regels betreffende de verwerving van de nieuwe onafhankelijke Staat en het verlies van de nationaliteit van de voorgangerstaat niet slechts dusdanig te ontwerpen dat staatloosheid wordt voorkomen, maar ook dat onnodige migratiegolven worden vermeden. 
Centraal bij dit alles staan de personen wier positie beïnvloed wordt door de eventuele onafhankelijkheid van de vermelde regio's. Deze personen zouden vanwege de statenopvolging kunnen worden geconfronteerd met een wijziging van hun status als burgers van een Lid-Staat van de Europese Unie en daardoor van hun status als Europese burgers, of - meer algemeen - met een wijziging van het juridisch kader dat van toepassing is op het grondgebied waar zij onder de paraplu van het Europese recht woonachtig zijn. Zij kunnen in een situatie terechtkomen, waarin strategische beslissingen moeten worden genomen teneinde een bepaalde status onder Europees recht te behouden of om de voorzetting van hun verblijfsrechten te verzekeren. Deze strategische beslissingen moeten overigens ook worden genomen in het nieuwe scenario dat door de "Brexit" is ontstaan. In dit boek wordt in het bijzonder de rechtsposities van burgers van de afgescheiden regio's geanalyseerd, die in de nieuwe Staten woonachtig zijn of op het grondgebied van andere Lid-Staten van de Europese Unie wonen, alsmede de rechtsposities van Europese burgers en burgers van derde landen die op het afgescheiden grondgebied woonachtig zijn.

Dit proefschrift hanteert een multidimensionale benadering, waarbij met drie verschillende maar met elkaar verbonden rechtsordes rekening wordt gehouden: internationaal publiekrecht, het nationaliteitsrecht van de betrokken Staten en Europees recht. Het internationaal publiekrecht is in het bijzonder relevant voor de studie van de criteria voor het zijn van Staat, statenopvolging, nationaliteitsproblemen ten gevolge van statenopvolging, het lidmaatschap van internationale organisaties en de problematiek van de automatische toetreding tot mensenrechtenverdragen.

Geconcludeerd wordt, dat de veronderstelling dat de nieuwe onafhankelijke Staten automatisch Lid-Staten van de Europese Unie zijn, in het licht van het internationale recht en de praktijk van internationale organisaties nogal speculatief is. Theorieën die de automatische toetreding (toetreding van binnen/ interne vergroting) van deze regio's tot de Europese Unie verdedigen, zijn niet realistisch. Er zal in beginsel een tussenperiode zijn tussen het moment van onafhankelijkheid en de toetreding tot de EU. Dientengevolge zal de nieuwe onafhankelijke Staat geen Lid-Staat van de EU zijn en is Europees recht op het moment van onafhankelijkheid niet van toepassing op het grondgebied van de nieuwe Staat.

Dat zo zijnde is het aan de voorgangerstaat/ Lid-Staat van de EU en aan de opvolgerstaat/ niet Lid-Staat van de EU om de nationaliteitsregels vast te stellen die moeten worden aangenomen ter gelegenheid van de onafhankelijkheid. Het internationale recht bevat daarvoor enige beperkingen (zoals de vermijding van staatloosheid), maar het Europese recht eveneens. De voorgangerstaat, die Lid-Staat van de Europese Unie is, moet rekening houden met het Europese recht bij de vaststelling van 
de regels betreffende het verlies van de nationaliteit door burgers die de nationaliteit van de nieuwe onafhankelijke Staat verwerven. Bovendien, als de nieuwe Staat Lid-Staat van de EU wil worden, doet deze er met het oog op toetredingsonderhandelingen verstandig aan zijn nationaliteitsrecht dusdanig te regelen dat dit aanvaardbaar is voor de EU.

In deze samenhang moet speciale aandacht worden besteed aan de nationaliteitspositie van minderjarigen en van derdelanders. Een complicerend element waarmee rekening moet worden gehouden betreft het feit dat zowel in Catalonië als in Schotland minderjarigen die de leeftijd van 16 jaren hadden bereikt, konden meestemmen over de vraag of deze regio's onafhankelijk zouden moeten worden.

Hoewel een referendum als dusdanig nog niet de onafhankelijkheid van een bepaalde regio bewerkstelligt, is het wel de eerste stap naar onafhankelijkheid, welke gevolgen zal kunnen hebben voor de nationaliteitsstatus van de personen die woonachtig zijn op het grondgebied dat zich wil afscheiden, inclusief voor aldaar wonende derdelanders. Er bestaat geen verplichting voor de nieuwe onafhankelijke Staat om de nationaliteit ook aan aldaar woonachtige migranten aan te bieden. Indien evenwel bepaalde migranten hun stem mogen uitbrengen in het referendum of onafhankelijkheidsconsultatie, is het wel van groot belang dat zij goed geïnformeerd worden over hun rechtspositie na de onafhankelijkheid. In zijn algemeenheid geldt dat het onaanvaardbaar is, dat onduidelijk is wie na de onafhankelijkheid burgers van de nieuwe Staat zullen zijn. Het beleid ten aanzien van de nationaliteit moet ruim vóór de onafhankelijkheid bekend worden gemaakt en dient idealiter zelfs bekend te zijn op het moment dat een referendum plaatsvindt.

Terwijl de nieuwe Staat niet ogenblikkelijk een Lid-Staat van de EU zal zijn en derhalve niet gebonden is aan het Europese recht, ligt dit anders met betrekking tot de verplichtingen die voortvloeien uit het EVRM, in het bijzonder met betrekking tot het recht op respect voor privé-, familieen gezinsleven. De drie Staten die in deze studie centraal staan, zijn LidStaten van de Raad van Europa en zijn derhalve gebonden aan het EVRM. Bovendien zullen ook de potentiëlenieuwe onafhankelijke Staten Lid-Staten van de Raad van Europa worden. Het is daarom op zijn plaats om rekening te houden met de mogelijke toepassing van de theorie van automatische statenopvolging met betrekking tot verdragen aangaande fundamentele mensenrechten. Maar zelfs als de nieuwe Staten niet automatisch het EVRM zouden moeten toepassen, zal niettemin de Kuric doctrine van het EHRM van toepassing zijn in geval van de eventuele onafhankelijkheid van Catalonië, Vlaanderen of Schotland, zoals Vidmar dit in de contekst van het Schotse referendum voor het eerst heeft onderstreept. 
In het scenario van een eventuele onafhankelijkheid van Catalonië, Vlaanderen of Schotland zijn - conform de lijn van Vidmar - de verblijfsrechten van bepaalde groepen personen die woonachtig zijn op het grondgebied van de potentiële nieuwe onafhankelijke Staat, in de voorgangerstaat of in andere Lid-Staten van de EU beschermd. Maar deze bescherming is beperkt tot de verblijfsrechten zoals deze worden genoten op het moment van de onafhankelijkheid en ook beperkt tot het grondgebied van de Staat waarin betrokkenen woonachtig zijn. Daarom lijkt het op zijn plaats om met Vidmar te stellen, dat een bundel rechten wordt 'bevroren', in het bijzonder omdat deze bescherming territoriaal beperkt is. Het recht om te verblijven op het grondgebied van de nieuwe onafhankelijke Staat, de voorgangerstaat of andere Lid-Staat van de EU zal in elk geval worden beschermd door toepassing van de Kuric formule. Daarom zijn de verblijfsrechten beschermd van burgers van de nieuwe onafhankelijke Staten wonende in de voorgangerstaat of in andere LidStaten van de EU; van burgers van de voorgangerstaat of andere LidStaten van de EU wonende in de nieuwe onafhankelijke Staten; en van derdelanders wonende in de nieuwe Staten. Vanuit een praktisch dag tot dag perspectief mag hun verblijfsrechtelijke rechtspositie niet veranderen: hun recht op respect voor privé-, familie- en gezinsleven - nauw verbonden met hun verblijfsstatus - moet worden gerespecteerd.

Civis europaeus sum? Deze vraag vormt de hoeksteen van dit proefschrift. Naast alle gecompliceerde juridische kwesties in verband met een eventuele statenopvolging binnen een Lid-Staat van de EU is dit de vraag waarop de mensen die door die situatie geraakt worden, een antwoord willen. De band tussen de nationaliteit van een Lid-Staat van de EU en het burgerschap van de Unie is - naar de huidige stand van zaken onlosmakelijk. Men kan geen aanspraak maken op het Unieburgerschap, als men niet de nationaliteit van een Lid-Staat bezit. Daarom zullen zij, die wegens de in het kader van de statenopvolging tot stand gekomen nationaliteitsregelingen de nationaliteit van de voorganger-EU-Lid-Staat verliezen, niet met succes het 'civis europaeus sum' kunnen inroepen. In principe verliezen personen die de nationaliteit van een Lid-Staat van de EU verliezen, eveneens hun Europees burgerschap en de daaraan verbonden rechten. Desalniettemin zullen, hoewel het Europese burgerschap nog niet los van de nationaliteit van een Lid-Staat kan bestaan, sommige daaraan verbonden verblijfsrechten in zowel de potentieel nieuwe onafhankelijke Staat als in Lid-Staten van de EU - zoals ook Vidmar dit stelde - als interim oplossing worden bevroren in afwachting van de voltooiing van de toetredingsprocedure van de nieuwe Staat tot de Europese Unie.

De rol van het Europese burgerschap kan in dit scenario niet worden overschat. Gelet op de huidige stand van zaken is het burgerschap van 
de Unie - tenminste vanuit juridisch perspectief - niet voldoende om de automatische toetreding van de potentiële nieuwe Staten tot de Europese Unie te verdedigen. Hoewel deze nieuwe Staten de toetredingsprocedure tot de EU niet kunnen omzeilen, speelt het Europese burgerschap niettemin een rol vanwege de invloed van het Europese recht op het nationaliteitsrecht van de voorganger-EU-Lid-Staten, in het bijzonder door de toepasselijkheid van het evenredigheidsbeginsel op beslissingen betreffende het verlies van de nationaliteit. 



\section{Valorisation Addendum}

\section{Societal Relevance of this Thesis}

Independence movements in EU Member States and, more recently, the United Kingdom's referendum on EU membership have reignited the debate on the enjoyment of certain rights by people directly affected by an eventual State succession within an EU Member State (or withdrawal from the EU, in the case of the United Kingdom). The growing number of research literature and the attention given to these issues by the general media, demonstrate not only to the topicality of this issue but also to the sense of uncertainty surrounding it.

This research provides a legal analysis of the specific consequences of an independence process within an EU Member State for the people affected by such an event. These people, by the operation of a hypothetical State succession, could witness a change of their status as nationals of an EU Member State and, therefore, citizens of the Union or, more generally, a change of the legal framework applicable to the territory where they have been residing under the umbrella of EU law. They could find themselves in a position where strategic decisions have to be made in order to retain a certain status under EU law or in order to guarantee the continuation of certain residence rights. These strategic decisions must also to be taken into account as a result of the new scenario posed by "Brexit". In this regard, this research examines different, yet intertwined, legal orders in order to remove uncertainties that will be faced, not only by citizens of the Union and nationals of the potential new States, but also by third-country nationals.

The societal impact is, in this regard, obvious. Since the possession of the nationality of an EU Member State presupposes the enjoyment of the rights deriving from the EU citizenship status, the present research has a direct impact on the question of what happens with those rights. The population which can potentially be affected involves not only the citizens of the new countries born as a result of a succession process, but also the nationals of other EU Member States residing in these new States, as well as third country nationals which enjoy certain rights under EU law. Furthermore, the findings related to the retention of certain rights associated to the residence in both the potential newly independent States and the EU Member States can also be applicable to the "Brexit" scenario. 
This research also has potential value for scholars, as it adds a new approach in the study of the EU citizenship and nationality law issues. Furthermore, it contributes to the debate regarding the EU competences in the field of nationality law and it delves into the question of whether the autonomy of the EU Member States should be constrained to the extent that such autonomy conflicts with EU citizenship status granted by EU law. It will also open potential new research areas, especially dealing with the link between the nationality of an EU Member State and citizenship of the Union and that is, as it stands now, unbreakable. Perhaps the time has come to further develop or re-think the concept of citizenship of the Union and provide it with higher degree of autonomy from Member State nationality.

\section{Target Groups for the Research Results}

The results of the research can be taken as general guidelines regarding current and future independence movement within the EU that will be useful for the EU institutions themselves and EU Member States dealing with their own independence movements. The research focuses on the situations in Catalonia, Flanders and Scotland, but there are other potential segregation movements within the EU that can potentially follow the same pathway. Galicia in Spain, the Basque Country in Spain and France, Brittany in France or the Frisian Region in The Netherlands are some examples of independence movements within EU Member States. The results of this research can help these areas of a Member State to carry out the independence process with certainty, especially regarding nationality and EU citizenship issues. In this regard, the findings of the research can be helpful not only for the legislature of the potential new States but also for the remaining EU Member States in the field of nationality law.

Similarly, the results can help to reaffirm the role of the Council of Europe in nationality matters. Hitherto, the debates on the implications of an eventual Catalan, Flemish, or Scottish independence have been limited to EU law and international law. However, the human rights dimension of these rights, especially the residence rights as linked to the obligation to respect private and family life as provided in the ECHR, has largely been ignored.

\section{Innovative Character of this Thesis}

This project focuses on the status of EU citizenship and the laws governing nationality within the framework of a State succession. Its innovative character lies, firstly, in the novel situation that is under research. And 
secondly, only a few scholars have undertaken research on this particular subject.

Certainly, the European continent experienced States successions in Czechoslovakia, the Baltic States and Yugoslavia but those situations are not comparable with the independence movements in Spain, Belgium and the United Kingdom. There is no precedent within the EU in which a devolved part of an EU Member State has become independent, and therefore for the first time in the EU's history it is facing potential cases of succession of EU Member States. This process will result in a remaining EU Member State and a succeeding State. What will be the situation of such a new State and its citizens? There is no clearly defined position of the European institutions in relation to the phenomenon of State succession, despite the obvious implications that such a situation would have on the eventual depravation of the rights flowing from the EU citizenship, but also regarding the future nationality acts of the new States.

Scholars have not addressed the issue of State succession within the framework of the EU, and the implications of such a situation for the status of the EU citizenship. It is true the State succession is a topic that has received a plethora of attention from scholars, but not within the framework of union of States in which the EU citizenship status is intended to be the fundamental status of nationals of the Member States. In the case of Catalonia and Flanders, there are few papers that focus on the legal paths to independence within the legal system of Spain and Belgium respectively and the historical, societal or economic grounds that would support their independence. The citizenship questions are vaguely treated.

Following the "Brexit", a large number of papers and research literature have been published, none of them have explored the human right dimension of the topic, however. This further demonstrates the originality of this research, together with the analysis made on the position of minors who reached the age of 16 years-old and were enfranchised in the Catalan and Scottish independence queries.

\section{Concrete Products, Services, Processes and Activities into which the Research Results will be translated and shaped}

The results of this thesis have already been partially disseminated to an academic audience via conferences and workshops; for instance the 'Pro-independence Movements and Migration: Discourse, Policy and Practice' workshop held by the European Academy (EURAC) in Bolzano, Italy and the $19^{\text {th }}$ annual Ius Commune Conference, held in Edinburgh, United Kingdom with a presentation titled 'Nationality and European 
citizenship consequences of the independence of a part of a Member State'. The dissemination of the research has continued with additional presentations, for instance at the Farewell Seminar of Prof. G.-R. de Groot in October 2016.

Additionally, several papers have been published already in Spain (Revista de Derecho Comunitario Europeo, 'La ciudadanía Europea en venta. El programa de venta de la nacionalidad maltesa: $i$ una brecha en el principio de cooperación leal en el ámbito de ciudadanía de la Unión?') and in the Netherlands (Tijdschrift voor Constitutioneel Recht, 'Catalonia's independence and the role of the Constitutional Court: recent developments'). Forthcoming publications include a chapter in an edited volume composed of the main research presented at the workshop 'Proindependence Movements and Migration: Discourse, Policy and Practice', held by the European Academy (EURAC) in Bolzano with the title 'The role of migrants in the Catalan independence process: a legal analysis' and another paper "Brexit": Consequences for Citizenship of the Union and Residence Rights' to be published in the Maastricht Journal European Comparative Law.

In addition to this, there has also been participation in EU-funded projects such as the ILEC (Involuntary Loss of European Citizenship) project, a research project aiming to fill the knowledge gap concerning the rules and administrative procedures applicable to loss of nationality across the Union, and their relation to existing European and international legal standards. As a result of the project, in February 2016 the book 'European Citizenship at the Crossroads' was published, with a chapter dealing with the attribution of Spanish nationality law and a case note on a Spanish ruling about the application of the so-called Rottmman doctrine (Judgment of the Court of Justice of the European Union of 2 March 2010, Janko Rottmman v Freistaat Bayern, C-135/08), which is a cornerstone of this research, given its importance for the practice of Member States in the field of nationality and the design of EU citizenship.

Participation on student forums has also served for the purpose of disseminates the research findings. For instance, performing as tutor at the annual conference Student Forum Maastricht 2015, leading the discussions in the 'Independence of Regions in the EU' panel, or the forthcoming interview in the Universidad Autónoma de Madrid online magazine, 'Ágora'.

The results of this thesis have also been made available to non-academic audiences mainly through weblog of the Faculty of Law 'Maastricht Law News and Views'. 


\section{Implementing the Research Results}

In order to further the implementation of the research results, this thesis will be distributed amongst the EU institutions, the Council of Europe and the governments of EU Member States dealing with independence movements and devolved regions seeking their independence.

Similarly, the results of this thesis will also be made available to nonacademic audiences mainly through blogs and interviews in general media.

With the on-going "Brexit" process, participation in academic and nonacademics debates on the topic on the eventual loss of EU citizenship is necessary. It would be desirable to obtain additional financial sources to engage in postdoctoral research dealing with the consequences of the withdrawal of the United Kingdom from the EU for nationality and EU citizenship status. 



\section{Resumé}

Guayasén Marrero González (San Cristóbal de La Laguna, 24 January 1985).

After obtaining his Law Degree at the Universidad de La Laguna in the Canary Islands, Spain (2003-2008), Guayasén Marrero González worked as an associate lawyer at the labour law - litigation department of the Spanish law firm "I\&A Garrigues, SLP" (2008-2010). He obtained a Master Executive in Company Law from Centro Europeo de Estudios y Formación Empresarial Garrigues S.L.P. He also worked at the Faculty of Law, Universidad de La Laguna, as a part-time assistant lecturer in the Department of Public International Law (2011-2012).

In 2013, he obtained his Master's Degree (LL.M.) in European Law at Maastricht University where he was awarded a scholarship funded by the Canary Islands' Government.

In 2014 he was granted a scholarship from the Spanish Foundation la Caixa (Programa Europa 2014) which funded his doctoral research at the Maastricht University Faculty of Law. 
